



\section{THE MONROE DOCTRINE}

AN INTERPRETATION 
Digitized by the Internet Archive in 2007 with funding from Microsoft Corporation 


\section{THE MONROE DOCTRINE}

\section{AN INTERPRETATION}

BY

ALBERT BUShNelL HART, Ph.D., Litr.D., LL.D. PROFESSOR OF THE SCIENCE OF GOVERNMENT IN HARVARD UNIVERSITY

WITH COLORED MAP
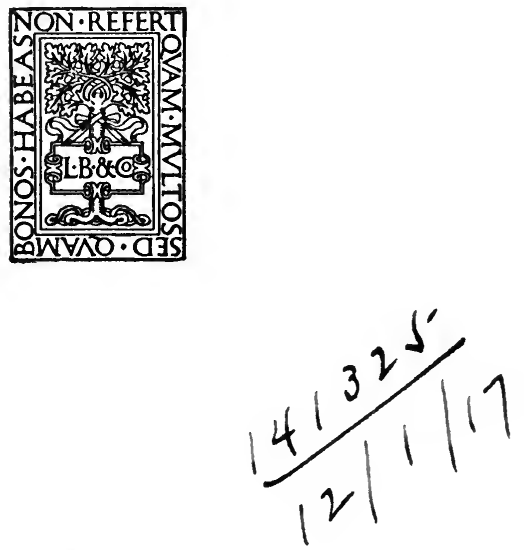

BOSTON

LITTLE, BROWN, AND OOMPANY 
Copyright, 1916,

By Little, Brown, and Company.

All rights reserved

Published, January, 1916

Normood 71 Fress

Set up and electrotyped by J. S. Cushing Co., Norwood, Mass., U.S.A.

Presswork by S. J. Parkhill \& Co., Boston, Mass., U.S.A. 


\section{PREFACE}

No public policy of the United States has ever taken such hold upon the imagination of the American people as the socalled Monroe Doctrine. It has been quoted, discussed, stated, re-stated, revised, and re-issued for nearly a hundred years. During the last fifteen years the Doctrine has been applied to a much wider range of objects than in its earlier history. The expansion of Pacific relations, the Panama Canal and the Caribbean policy of the United States, have brought it into new complications, requiring new definitions and widening the circle of public interest. Its meaning and its immediate cogency are still uncertain and disputed.

To treat this complex topic in a single volume has been a difficult task, and the author cannot claim to have escaped misapprehensions and contradictions; for the Monroe Doctrine itself is tinged with misapprehensions and abounds in contradictions. To the author's mind the Monroe Doctrine is not a question of theory but of fact. It is founded on the state of things in the Western Hemisphere. It includes much that is not agreeable to the people of the United States, but which must be faced because it exists. Meanwhile, the conditions of the problem change from decade to decade; and any Doctrine which is to endure in the midst of these changing conditions must undergo corresponding alterations.

The volume is divided into seven Parts, of which the first is devoted to the underlying conditions of the new LatinAmerican states who became parties to American Diplomacy; and to the text and the motives for the first official statements. Here and throughout the work quotations have been freely made and they appear in smaller type. Wherever the quotation contains a statement of the theory or 
practice of the relations of the United States with other American countries, an inset heading in black faced type summarizes the Doctrine there stated.

Parts II and III are occupied with the growth of American relations and the efforts of Presidents, Secretaries of State, and other statesmen to frame new forms of doctrine to correspond. The first three Parts - something more than half the volume - contain therefore a condensed history of the Monroe Doctrine, with illustrative texts and comments.

Parts IV and V are interpretative, being built upon the previous historical part of the work; they restate and discuss the same facts in new combinations, iliustrated by the views of modern writers of many nations. The Latin-Americans, Europeans, and Asiatics help to determine the meaning of the Monroe Doctrine.

It is no function of this work to predict the future history of America: but in Part VI the attempt is made to point out how far the Doctrine in its present meaning is likely to be applied in the future; and what steps are possible and likely for the United States to take in order to maintain it. Part VII is a brief survey of the most important books dealing with the subject.

In the preparation of the volume the author has arrived at his conclusions without the criticism of other scholars upon the copy or proof. This method has doubtless led to some errors of fact and deduction; but it seems more positive and vital than to submit it to the preliminary comment of friends. The one person who has had a share in the preparation of the work is Mr. David M. Matteson, who has diligently verified the quotations, assisted in making the map, read the proofs, and called attention to pitfalls into which otherwise the writer would have fallen. Others will doubtless point out omissions and errors. No attempt has been made to include every episode and discussion which might be mentioned, and the author can claim only a purpose to be as exact as frailties of authorship allow. He has set forth the policies and motives of his country honestly and with a strong sense of what we owe to those who have maintained the Monroe Doctrine.

ALBERT BUSHNELL HART.

Cambridge,

November 4, 1915. 


\title{
CONTENTS
}

\author{
PART I
}

\section{THE ORIGINAL MONROE DOCTRINE}

\author{
1775-1826
}

\section{CHAPTER I}

The New United States (1775-1823) • • • • .

What is the Monroe Doctrine? - Isolation of Europe Rival Influences in America - Spanish Colonial Empire Effect of the American Revolution (1775-1789) - Early Doctrine of Isolation (1780-1789) - Washington's Policy of Isolation (1793-1796) - Later Doctrine of Isolation (1797-1823) - Counter Doctrine of European Aloofness Expansion into Wild Territory - The United States as an American Power in 1823.

\section{CHAPTER II}

The New Latin-American Powers (1783-1823) • •

European Colonies in America in 1783 - Race Elements in Latin America - Uneasiness in the Spanish Colonies (1783-1807) - First Spanish-American Revolutions (18061812) - Sympathy of the United States - Preliminaries of Recognition - Second Era of American Revolutions (18141821) - Neutrality of the United States (1814-1822) Recognition of the Latin-American States (1816-1823) Social and Material Conditions in Latin America in 1823 - Political Conditions of Latin America in 1823 - Possibilities of Latin-American Union. 


\section{CHAPTER III}

Europe's Interest in America (1814-1823)

Interest of Spain and France - Interest of EnglandThe Holy Alliance (1815-1822) - Work of the Holy Alliance (1810-1822) - Interventions in Europe (1818-1823) - Proposed European Intervention in America (18181822) - Controversy with Russia (1821-1823) - Attitude of England (1818-1823).

\section{CHAPTER IV}

Formulation of the Monroe Doctrine . . . . $55-68$

Ground prepared for a Doctrine-Monroe and Adams - Cabinet Debate on Joint Declaration - Cabinet Debate on Political System - Cabinet Debate on Warning to Europe-Authorship of the Monroe Doctrine - Text of the Original Monroe Doctrine.

\section{CHAPTER V}

INTERpretation of the Original Monroe Doctrine (1824-1826) .

The Unwritten Monroe Doctrine - Doctrine of the Two Spheres - Doctrine of Intervention - Doctrine of Colonization - Doctrine of Political System - Doctrine of Protection of the United States - Geographical Extent of the Doctrine-Influence of Trade-Geographical Intent of Monroe - Was the Monroe Doctrine International Law? - The Monroe Doctrine and Peace-Leadership of the United States.

\section{CHAPTER VI}

Test of the Monroe Doctrine (1824-1826) . . .

Effect of Monroe's Declaration in Europe (1823-1824) - Effect of Mouroe's Declaration upon Latin America Effect of Monroe's Declaration on the United States (18221824) - Colonization in the Northwest (1823-1824) - The Clay Doctrine (1824-1825) - The Adams Doctrine (1826) - Discussions on the Panama Congress (1826) - Failure of the Panama Congress - Outcome of the Panama Congress (1826) - Status of the Monroe Doctrine in 1826. 


\section{PART II}

\section{VARIATIONS OF THE MONROE DOCTRINE 1827-1869}

\section{CHAPTER VII}

Development of Latin-American Nations (1827-1844)

Lines of American Development (1827-1844) - Confusion and Anarchy (1827-1844) - Trade and Boundaries (1827-1844) - Falkland Islands (1831-1832) - Protection of Cuba (1827-1844) - Anti-Monroe Aspirations for Territory - The Monroe Doctrine and Slavery (1836-1844) Reawakening of the Monroe Doctrine (1844).

\section{CHAPTER VIII}

The United States out of her Sphere (1845-1853) $112-127$

A Change of Principles (1845) - The Polk Doctrine (1845-1849) - Americanism in Europe (1830-1851) Isthmus Canal (1848-1849) - Cuba (1846-1851) - Sympathy with Hungary (1849-1850) - Clayton-Bulwer Treaty (1848-1850) - The Monroe Doctrine in the Treaty - The Aftermath of Conquest (1845-1852).

\section{CHAPTER IX}

Doctrine of American Supremacy (1853-1861) $128-141$

Framers of our Foreign Policy (1853-1861) - Conditions of America - Proposed Joint Guaranty in Cuba (18511852) - The Cass Doctrine (1853-1858) - Designs on Cuba (1853-1854) - Minor Territorial Ambitions (18531860) - Guano Islands - Designs on the Isthmus and Mexico (1853-1861) - United States in European Diplomacy (1854-1861) - Status of the Monroe Doctrine in 1861.

\section{CHAPTER $\mathrm{X}$}

How to Get ON without Monroe (1861-1869) . $142-159$

Latin America in 1861 - Seward's Conception of America - European Invasion of Mexico (1861-1862) - The 
United States on Mexico (1861-1862) - The Seward Doctrine (1861-1869) - Annexation Projects (1865-1877) Latin-American Wars (1861-1869) - Withdrawal of the French from Mexico (1865-1867) - Canada (1865-1867)Alaska (1867) - Preparing the Way for a Canal (18641869) - The Johnson Doctrine (1868) - Results of Seward's Diplomacy (1861-1869).

\section{- PART III}

\section{THE AMERICAN DOCTRINE}

\section{9-1915}

\section{CHAPTER XI}

Doctrine of Paramount Interest (1869-1884)

$161-182$

Change of Emphasis - Three Secretaries of State (18691882) - The Grant Doctrine and Cuba (1866-1870) - The Fish Doctrine (1870) - Settlement of the Cuban Question (1869-1878) - Fish's Canal Diplomacy (1869-1875) Evarts and Hayes Doctrines - The Blaine Doctrine (1881) - Postponement of the Blaine Doctrine (1882-1885) Hegemony in America (1881-1885) - Intervention in South America (1881-1883) - The Gains and Losses of Sixteen Years (1869-1885).

\section{CHAPTER XII}

The American Doctrine against Great Britain (18851898)

Political Conditions (1885-1895) - Canal Conditions (1885-1890) - Reciprocity with Latin America (18841897) - Pan-American Congress (1889-1890) - Difficulties with Chile and Brazil (1891-1894) - Venezuela Controversy (1881-1895) - The Olney Doctrine (1895) - The Cleveland Doctrine (1895) - The Salisbury Doctrine(1895) - The Lodge Doctrine (1895) - Occasion of the Cleveland-Olney Doctrine - State of the Monroe Doctrine in 1898. 


\section{CHAPTER XIII}

The West Indies and the Canal (1898-1903)

Cuban Insurrection (1895-1898) - Spanish War (1898) - American Policy in Asia (1885-1900) - American Policy in Africa (1884-1906) - American Doctrine at the Hague Conferences (1899-1907) - Withdrawal of Great Britain from the Canal (1900-1901) - Preparations for an American Canal (1899-1902) - Canal Treaty with Panama (1902-1904) - The United States in the Eyes of Spanish America (1903) - The New American Situation (1903).

\section{CHAPTER XIV}

The Roosevelt Doctrine and its Successors (1901-1915)

The Monroe Doctrine always with us - Text of the Roosevelt Doctrine (1901-1906) - Pan-American Congresses (1901-1915) - Venezuela Controversy (1902-1903) - Santo Domingo (1905-1915) - The Taft Doctrine (19091913) - Magdalena Bay Episode (1912) - The Root Doctrine (1914) - The Wilson Doctrine (1913-1915) - The Written and the Unwritten American Doctrine.

\section{PART IV}

\section{PRESENT-DAY DOCTRINES}

\section{CHAPTER XV}

The Latin-American Doctrine

The Monroe Doctrine One-sided - Right of LatinAmericans to Think - Physical Power of Latin America - Race and Social Conditions - Latin-American Government-Latin-American Unions - The A B C Combination - Latin-American Liking for the Monroe Doctrine Latin-American Dislike of the Monroe Doctrine-The Latin-American Remedy.

\section{CHAPTER XVI}

Drago Doctrine and Calvo Doctrine (1902-1915) :

The Individual in American Affairs - Rights of Aliens in Latin America - Collection of Public Debts - Claims 
and Arbitration Methods - The Calvo Doctrine (18671915) - The Drago Doctrine (1902-1915) - The Ameriean Doctrine and the Drago Doctrine.

\section{CHAPTER XVII}

The German Doctrine . . . . . . . . 269-281

American Colonizers - Germans as Colonizers - Germans in North America - Germans in South America Colonial Hopes of Germany - Germany in Venezuela (1902) - German Views of the Monroe Doctrine - Danger from Germany - The American Doctrine in the European War.

\section{CHAPTER XVIII}

Pacific and Asiatic Doctrines.

Early American Interest in Asia - The Monrovoid Doctrine on Hawaii (1842-1849) - Hawaii in the United States (1850-1915) - American Pacific Islands-American Protectorate of Liberia - American Policy in Asia Protection of the Philippine Islands - Foundations of an Asiatic Doctrine - American Principle of the Open Door - Dual Understanding with Japan (1908) - Japanese Tests of the American Doctrine - Japan's Monroe Doctrine for Asia.

\section{PART V}

\section{PRESENT WORLD CONDITIONS}

\section{CHAPTER XIX}

\section{Changes of World Conditions}

Progressiveness of the American Doctrine-Exponents of Changed Points of View - Changes in Territorial Conditions - Present Territorial Field - Suggested Geographical Limitations - Expansion of the United StatesTransfers of American Territory - Conquests of Territory - Changes in European Conditions - Changes in Latin America. 


\section{CHAPTER XX}

Doctrine of American Protectorates

Responsibility of the United States to Europe - Responsibility to Latin America - Doctrine of Inferior Nations - Inferiority applied to Latin America - Liberties with Latin-A merican Sovereignty - Interventions by the United States - Protection of Latin-American States-Protectorate of Cuba - Protectorate of Panama (1903-1914) Protectorate of Santo Domingo (1905-1915) - Intervention in Central America (1906-1915) - Protectorate of Nicaragua-Dollar Diplomacy - Mexico and Protection - Fixed Policy of Protectorates.

\section{CHAPTER XXI}

Relation of the American Doctrine to Commerce

The West Indian Theory - Policy of Reciprocity Shipping - International Controversies over the Canal (1850-1900) - International Law of the Canal (1901-1905) - Effect on the Coasting Trade - The Canal and Latin America - General Question of Commerce.

\section{PART VI}

\section{DOCTRINE OF PERMANENT INTEREST}

\section{CHAPTER XXII}

Search for the Doctrine of the Future

Modern Definitions of the Monroe Doctrine - Foreign Definitions of the Monroe Doctrine - Objections to the Monroe Doctrine - The American Doctrine as a Universal Principle - A Protection to the United States - No Dependence on Extra-American Support-Promotion of Peace-Promotion of Commerce - Enforcement of the Responsibility of Latin America-The Future Doctrine must be Simple - The Author's Doctrine of Permanent Interest. 


\section{CHAPTER XXIII}

Peaceful Maintenance of the Doctrine of PermaNENT INTEREST • • • • • • • • • 371-384

The Monroe Doctrine a State of Mind - The National Determination - Force of the Example of the United States - Benevolent Leadership by the United States Inter-A merican Law -- Pan-American Organization - Limited American Organization - International Arbitration.

\section{CHAPTER XXIV}

Military Maintenance of the Doctrine .

American Belief in Peace - American Belief in Ourselves - The World's Belief in Force - Force upon Latin America - Temporary Defensive Alliances - Force upon Non-American Powers - Must the United States Have a Doctrine? - Readiness to Protect the Doctrine - War for the Doctrine-Facts of the Doctrine - A Guess at the Future.

\section{PART VII}

Materials on the Monroe Doctrine . . . . 405-421

INDEX • • • • • • • • • • $423-445$ 


\section{EXPLANATION OF THE MAP}

Names and boundaries in red are those of 1823 .

Names and boundaries in black are those of 1915.

Red bars or blocks show British territory or claims.

Yellow bars or blocks show former Spanish territory.

Brown bars or blocks show former Portuguese territory.

Green bars or blocks show French territory in the West Indies and Russian in the North Pacific.

Blue bars or stars show territory, claims, or dependencies of the United States. 



\title{
THE MONROE DOCTRINE AN INTERPRETATION
}

\section{PART I}

\section{THE ORIGINAL MONROE DOCTRINE}

\section{5-1826}

\author{
Chapter I \\ THE NEW UNITED STATES \\ $1775-1823$
}

WHAT IS THE MONROE DOCTRINE?

No term is more frequent in the literature of American history and international relations, than the Monroe Doctrine: it is conspicuous in school books; it reserves chapters in the most serious works; it forces a place in the reviews; it bursts out in the newspapers; it claims space in Presidents' messages, and in the addresses of public men. No well-regulated newspaper office or cyclopedia could get on without its Monroe Doctrine. To this hard-worked principle might be applied the criticism of Major Jack Downing upon Van Buren - who indeed, both as Senator and as President, had a direct relation with the Doctrine. "Everybody likes him, and he likes everybody, and he is just like everybody - and yet, in all the droves of folks I've seen - I never saw anybody like Mr. Van Buren."

This variety and uncertainty as to what the Monroe Doctrine really is, arises from an attempt to misuse the phrases which were put forward in 1823 for immediate consumption, in order 
to forestall difficulties then serious but now mostly passed by. These phrases have been made to cover policies and controversies which were not in the minds of the men of 1823: they could not possibly foresee the immense changes in conditions in Europe, in the world at large, and especially in America, which have required new statements of policy. Hence nobody nowadays knows just what is meant by the phrase "Monroe Doctrine", - it is a changeable expression, used frequently to electrify current opinions on the relations of the United States with Latin America by dynamic statements made a century ago.

There is however a perpetual national policy which needs no authority from President Monroe or any later public man, to make it necessary or valid. It is the daily common-sense recognition of the geographic and political fact that the United States of America is by fact and by right more interested in American affairs, both on the northern and southern continents, than any European power can possibly be.

What is called the Monroe Doctrine, in all its varieties and ramifications, is only an attempt to apply this simple principle to changing needs and conditions. Let us call this obvious undeniable principle, which includes the formal statements of ten presidents and twenty secretaries of state, the American Doctrine. Of late the conditions in America have grown very difficult; in the last twenty years new and far-reaching enlargements of policy have been revealed; while the European war of 1914 has disturbed the international organization of the world and introduced a new element of complication into the relations of the American nations between themselves and with foreign countries. These perplexing changes must also be taken into account in the endeavor to state clearly the present meaning and extent of the Monroe Doctrine.

\section{ISOLATION OF EUROPE}

The foundation of the relations of the-United States with her neighbors is the physical makeup of the American continent, and its relation to the rest of the world. The bottom stratum of the foundation of the Monroe Doctrine is the isolation of Western Europe from Asia, and the separation of the Western Hemisphere from both Asia and Europe. In these days of exploration, when the six other continents, Asia, Africa, North 
America, Souch America, Australia and the Antarctic, have been forced at last to yield up the secret of their remotest areas, it is hard to realize the lack of geographic curiosity among ancient and mediæval peoples. We moderns feel compelled to follow every stream to its source; to climb every mountain ; to follow every furlong of sea-coast; to map all shores and islands.

Some of these discoverers have been looking for furs or timber or minerals or gold; most of them have been animated by the sheer love of being the first to set foot upon a spot which hitherto had escaped civilized man. In their track followed the surveyor, the railroad builder, and the settler. To make a new land known is the first step to colonization; before you realize it, a nation grows up in Australia, or New Zealand, or South Africa, where for countless ages there has been only a wilderness supporting savage tribes.

The ancestors of the European races had little of this love of discovery for discovery's sake. Therefore, for over two thousand years, down to about A.D. 1500, the round world contained three continents unvisited by Europeans - Australia and the two Americas; and also included two groups of highly civilized people living on adjacent continents, yet almost unknown to each other.

These two groups of civilized peoples, each entirely alien to the other, were apparently kept apart only by military considerations; nobody knew how to carry a conquering army in either direction across southern Asia or across the Indian Ocean. If conquest was not possible, neither group felt interested in the civilization and history of the other. The power of Islam, which spread both East and West, somehow failed to become a connecting link: until the voyage of Vasco da Gama to India in 1496, the Orient and the Occident had as little to do with each other as Greenland and Madagascar have to-day. Successive hordes of northern Asia found a way into Europe, but there was no return conquest. Hence there arose a separate European group of states, a European type of community, a European political system.

\section{RIVAL INFLUENCES IN AMERICA}

Both the East and the West failed likewise to make obvious connections by sea. From the Cape Verde Islands to the coast of Brazil is only about two thousand sea miles; from 
Norway to Labrador, via Iceland, there is nowhere a gap between lands of a thousand miles. Yet the discoveries of unknown islands by the Norsemen went unheeded, and it was reserved for Columbus, in 1492, an Italian in the service of Spain, to be the first scientific discoverer and explorer of the New World. Almost immediately he was followed by John Gabot in 1497, sailing in behalf of England.

Thus, more than four centuries ago, was laid the original foundation stone of the Monroe Doctrine. Before any European had as yet laid eyes on the mainlands, a rivalry appeared between the Latin and the Teutonic race-stocks for the control of the two continents which shortly came to be called America. That contest began an age-long struggle between Latin Spain and Teutonic England, for lands to colonize in the New World, and for supremacy over the adjacent seas. By the Revolution of 1775 the British influence fell to the former English colonists who formed the United States of America. The Latin influence was upheld by the former Spanish and Portuguese colonists, and for the first time the two groups set out to live in harmony.

The relations between these groups was much affected by the fact that the European colonizing nations came upon their portions of the New World almost by accident. The Spaniards happened to strike the West Indies, and thence passed to the nearest shores of the two continents. They never made significant settlements north of a line drawn through St. Augustine, Pensacola, Nagodoches, Santa Fé, and San Francisco. In South America, except for the comparatively small settlements on the La Plata, they took up only a narrow belt of territory extending along the northern and western coasts. The French in pursuit of furs settled on and near the St. Lawrence River and Gulf. The English unwillingly accepted the broad and fertile belt lying between the colonies of the two Latin powers. Their permanent colonies were planted a century after the Spanish beginning; and it was fifty years longer before Spain would accept the fact that the English had made a permanent foothold in America.

The Spaniards had not even the foresight to occupy the mouth of the Mississippi, and allowed the French to preëmpt the whole valley of that magnificent river. On the Pacific, also, the Spaniards never thoroughly explored or occupied the 
coast north of Lower California until the middle eighteenth century. The result was that when the Spanish Empire broke up, immense fragments just west of the United States were really a no-man's land and early fell into the Latin-American system. As for the French, they were crowded out by the British in 1763. All other European colonies on the Atlantic Coast of North America were merged in the British. Off the continent there was a small area which for a century and a half was the battle ground between the Anglo-Saxon and the Latin. This was the West Indies. First Jamaica, later other West India islands, and even a belt of territory on the coast of Honduras, were seized from the Spaniards. The French also crowded in and occupied first half and then the whole of the island of Santo Domingo, and many smaller islands. The conquest of Jamaica (1655) marks the beginning of the decline of the Spanish-American empire; a decline which eventually made possible the independence of the Latin-American states who are now our neighbors. Into the Caribbean area, where the influence of the United States has in our day largely penetrated, the English began to get a foothold as early as Cromwell's rule.

\section{SPANISH COLONIAL EMPIRE}

Down to the American Revolutionary War the Spanish Empire in America included more than half the area of the two continents and outlying islands. The sovereign bore titles which testified to the passing magnificence of the Empire:

"DON CARLOS, by the grace of God, King of Castile, of Aragon, of the two Sicilies, of Jerusalem, of Navarre, of Granada, of Toledo, of Valencia, of Galicia, of Majorca, of Seville, of Sardinia, of Cordova, of Corsica, of Murcia, of Jaen, of the Algaves, of Algeciras, of Gibraltar, of the Canary Islands, of the East and West Indies, Islands and Terra Firma, of the Ocean sea, Archduke of Austria, Duke of Burgundy, Brabant, and Milan, Count of Apsburgh, of Flanders, Tirol, and Barcelona, Lord of Biscay and of Molina," etc.

On the face of things Spain had great advantages over the English colonies, such as a hundred years of start, tropical and sub-tropical climates, magnificent islands and harbors, control of the narrow crossings from the Caribbean Sea to the Pacific, 
and the sole European influence on the Pacific Coast of North America. Down to the American Revolution the preponderant influence in the Americas was still Spanish, and there was no proof then either that Spain would decay or that England would expand.

Against these advantages the English could count on several aids to growth and influence. The first was the conquest of the French potential empire in the St. Lawrence and the Mississippi valleys, crystallized by the Treaty of Paris (1763). Though Spain then received the whole west bank of the Mississippi River and a strip across the mouth of the river, the English were in possession of the most available block of land in North America, - fertile, various, well-watered, provided with splendid harbors, and good water routes on the interior rivers and lakes, reaching for a few years south to the Gulf. To this advantage must be added the unbroken refusal of the English to unite with the native Indians in a mixed race of citizens, a practice which had been going on for centuries in all parts of Latin America. The result was that the English continued to be an European race, while the Spanish-Americans were and are an American-European race.

Again, the English colonists were accustomed to look after themselves and in many directions to make their decisions; while the initiative in Latin-American government came, in most cases, from over-sea ; that is, Spanish America was governed by a country which was declining in wealth, population, and prestige. When it became clear during the eighteenth century that Spain could no longer protect her own European territory, when the English were strong enough to occupy Gibraltar in 1704, the control of Spain over the American colonial empire began to weaken.

\section{EFFECT OF THE AMERICAN REVOLUTION (1775-1789)}

In the rivalries for empire it hardly entered into the minds of the colonists that they were anything but outlying parts of Europe. They looked on themselves as Dutchmen or Swedes or Frenchmen or Englishmen or Spaniards or Portuguese living on the western continent. A Mexican or a Virginian who went to Europe claimed, and received in general, the status of a Spaniard or an Englishman. Most of the Spanish 
colonial governors and many of the English governors came from the home countries; and after amassing dignities and riches, they went home to those countries. The fundamental law and political and social customs of the colonists were the same as for their brethren at home; and to cover the conditions of the new world the home governments made many laws for their colonies. The wars between the colonies were. the reflections of rivalries between the mother countries in Europe. There was no America in the modern sense, still less any groups of American states.

Hence, the North American Revolution of 1775 did more than overturn the political system of the English colonies; it created a new kind of political unity, an American power, never before known in the history of the world. The English, Spaniards, Portuguese, and Dutch as conquerors in the Orient, found existing states, some of which were transformed into colonies. The United States of America reversed the process; out of communities which had never been anything but bits of Europe set in the western hemisphere, they constructed a new nation. This process and its results were very unwelcome to Europe. Except. for incomplete governments of Switzerland and Holland, the United States was the first independent republic which sprang out of European civilization. By this process was introduced into America a new type of political organization: for the state thus created was situated wholly in America, was dependent for its economic life upon American energy and capital; and was likely to make its fortune at the expense of the colonies of several European nations. As an example to such colonies the United States of America was dangerous; as a sister community to European outliers in America the new nation was disturbing; as a center of influence upon other American powers that might later arise, the United States was creating the condition out of which the Monroe Doctrine was eventually to come. Spain grudgingly countenanced the Ameriean Revolution, but all along dreaded the probable effect upon her own colonies, and was particularly nervous about the vigorous American settlers on the upper waters of the Mississippi River. The Spanish colonies were close to the United States, and it might safely be predicted that in the long run the new republic would absorb Spanish territory. Hence Spain scented danger to the colonies, danger to the Mississippi, 
and danger to Florida. These three apprehensions from the first disturbed the friendly relations of Spain and the United States. On the other hand, commercial interest moved the people of the United States to seek closer relations with Spain. In 1795 a commercial treaty was secured which, however, did not apply to the colonies. With the French West Indies, Portuguese Brazil, and the little Russian settlements in the North Pacific, the United States did not at that time concern herself. During the Revolution there was an attempt to annex Canada ; but the Canadians showed no desire to exchange their status under Great Britain for membership in the American Union.

During the Revolution the United States was too busy fighting to think of exercising a direct influence over the Spanish colonies, but did take a small part in extra-American affairs. Thus the capture of the port of New Providence in the Bahamas, in 1776, was a warning that the United States might take part in future naval wars in the West Indies. The appearance of John Paul Jones and other commanders in ships of war and privateer in European waters, was a suggestion that an American power might take part in European affairs. Negotiations with the Barbary Powers from 1783 to 1787 gave the United States the first taste of African complications. The opening up of profitable trade with China in 1784 was an evidence of a new interest of the United States in the Pacific Ocean and Eastern Asia.

So in America the foundations were laid for future annexations and commerce. The Russian occupation of tradingposts on the Northwest Coast in this period was the beginning of the eventual annexation of Alaska. The contraband trade with the Spanish colonies, which increased after the Revolutionary War, gave a foretaste of the commerce between the United States and neighboring parts of America. In 1786 the United States began to negotiate with Spain as one American power with another, on that same Mississippi question. The rising stripling was measuring himself against Goliath of America.

EARLY DOCTRINE OF ISOLATION (1780-1789)

With the adoption of the new constitution and the formation of a well-balanced government in 1789, the United States was 
fairly accepted by the rest of mankind as an independent nation, with a recognized place in the world. It fell to Washington, sagacious, experienced, and far-sighted, to propound a theory of the proper relations between the United States and European powers; for at that time all our neighbors were still segments of European countries. The new nation made a distinct contribution to the world's ideas on international relations by formulating the Doctrine of the Two Spheres, often called the Doctrine of Isolation. Thomas Pownall, formerly a colonial governor and always a clear-sighted friend to America, in his Memorial to the Sovereigns of America, in 1781, spoke of the "Empire of the United States", and laid down as a fundamental principle of American politics that there should be no connection with European politics:

"As nature hath separated her from Europe, and hath established her alone (as a Sovereign) on a great Continent, far removed from the old world and all its embroiled interests, it is contrary to the nature of her existence, and consequently to her interest, that she should have any connexions of Politics with Europe other than merely commercial."

The same idea was recorded by John Adams, November 18, 1782, in a conversation with the British Peace Commissioner at Paris, where he insisted that the United States must not be a make-weight:

"'You are afraid,' says Mr. Oswald to-day, 'of being made the tool of the powers of Europe.' 'Indeed I am,' says I. 'What powers?' said he. 'All of them,' said I. 'It is obvious that all the powers of Europe will be continually manœuvring with us, to work us into their real or imaginary balances of power. They will all wish to make of us a make-weight candle, when they are weighing out their pounds. Indeed, it is not surprising; for we shall very often, if not always, be able to turn the scale. But I think it ought to be our rule not to meddle; and that of all the powers of Europe, not to desire us or, perhaps, even to permit us, to interfere, if they can help it."'

During the discussions on the new constitution, this idea of isolation appeared in many forms and by many statesmen. Washington in 1788 wrote to Sir Edward Newenham as follows, against disturbance by European powers: 
"I hope the United States of America will be able to keep disengaged from the labyrinth of European policies and wars; and that before long they will, by the adoption of a good national government, have become respectable in the eyes of the world, so that none of the maritime powers, especially none of those who hold possession in the New World or the West Indies, shall presume to treat them with insult or contempt. It should be the policy of the United States to administer to their wants without being engaged in their quarrels."

No supreme wisdom was necessary to discover that the United States desired neither aid nor interference from Europe. The other half of the two spheres theory was as apt as the second jaw of a vise. Washington, January 1, 1788, wrote to Jefferson against taking part in foreign quarrels :

"We shall feel more than ever the want of an efficient general government to ... connect the political views and interests of the several states under one head in such a manner, as will effectually prevent them from forming separate, improper, or indeed any connexion with the European powers, which can involve them in their political disputes. For our situation is such, as makes it not only unnecessary, but extremely imprudent, for us to take a part in their quarrels ; and whenever a contest happens among them, if we wisely and properly improve the advantages, which nature has given us, we may be benefited by their folly, provided we conduct ourselves with circumspection."

\section{WASHINGTON'S POLICY OF ISOLATION (1793-1796)}

The policy of abstention from European affairs was put to a practical test when war broke out between England and France in 1793; and President Washington issued a neutrality proclamation. The position of neutrals was well enough understood, but it was a new thing for a government to warn its people of the danger of deviating from neutrality. The whole conception of the proclamation is that the United States could occupy a new and significant position, because she stood outside the controversies which gave rise to European wars.

This conception of neutrality was enforced by the first Neutrality Act of the United States, June 5, 1794; which made it an offense to enlist in the service of a belligerent while within the territory of the United States; to fit out and arm a vessel 
intended to commit hostilities on a belligerent; or to prepare expeditions to be carried on from the soil of the United States against a belligerent.

Notwithstanding this effort to limit America's activities to the American sphere, Genêt, the French minister, made every effort to force the United States to accept European guidance, by fitting out an expedition in the United States against the Spaniards in Louisiana. For this and other breaches of his duty, his recall was demanded. Just before retiring from the presidency, Washington, in his famous Farewell Address, gave to the Policy of Isolation a substance which has never been lost. The principal parts are as follows:

"The great rule of conduct for us in regard to foreign nations is, in extending our commercial relations, to have with them as little political connection as possible. So far as we have already formed engagements, let them be fulfilled with perfect good faith. Here let us stop.

Little political connection with Europe.

"Europe has a set of primary interests which to us have none or a very remote relation. Hence she must be engaged in frequent controversies, the causes of which are essentially foreign to our concerns. Hence, therefore, it must be unwise in us to implicate ourselves by artificial ties in the ordinary vicissitudes of her politics or the

No part in

European primary interests. ordinary combinations and collisions of her friendships or enmities.

"Our detached and distant situation invites and enables us to pursue a different course. If we remain one people, under an efficient government, the period is not far off when we may defy material injury from external annoyance; when we may take such an attitude as will cause the

Advantage of our situation. neutrality we may at any time resolve upon to be scrupulously respected; when belligerent nations, under the impossibility of making acquisitions upon us, will not lightly hazard the giving us provocation; when we may choose peace or war, as our interest, guided by our justice, shall counsel.

"Why forego the advantages of so peculiar a situation? Why quit our own to stand upon foreign ground? Why, by interweaving our destiny with that of any part of Europe, entangle our peace and prosperity in the toils of European ambition, rivalship, interest, or caprice?

"It is our true policy to steer clear of permanent alliances with any portion of the foreign world, so far, I mean, as we are now at liberty to do it; for let me not be understood as capable 
of patronizing infidelity to existing engagements. I hold the maxim no less applicable to public than to private affairs, that No perma- honesty is always the best policy. I repeat it, therenent alli- fore, let those engagements be observed in their ances. genuine sense. But in my opinion it is unnecessary and would be unwise to extend them.

"Taking care always to keep ourselves by suitable establishments on a respectably defensive posture, we may safely trust to temporary alliances for extraordinary emergencies."

\section{LATER DOCTRINE OF ISOLATION (1797-1823)}

Jefferson also sympathized with the policy of isolation and repeatedly expressed himself in its defense. In a despatch to Pinckney, then Minister to Spain, July 11, 1792, Jefferson pointedly deprecated meddling in European affairs :

"With respect to their government, or policy, as concerning themselves or other nations, we wish not to intermeddle in word or deed, and that it be not understood that our Government permits itself to entertain either a will or opinion on the subject."

A few years later, while Vice-President, he wrote to his friend Short of his horror at the idea of connection with European politics :

"There is no point in which an American, long absent from his country, wanders so widely from its sentiments as on the subject of its foreign affairs. We have a perfect horror at everything like connecting ourselves with the politics of Europe. It would indeed be advantageous to us to have neutral rights established on a broad ground; but no dependence can be placed in any European coalition for that."

As President, Jefferson several times enlarged upon this doctrine. In his inaugural address he congratulated his countrymen on being separated by the ocean from Europe:

". . . Kindly separated by nature and a wide ocean from the exterminating havoc of one quarter of the globe ; too high-minded to endure the degradations of the others ; possessing a chosen country."

A few days later, in a personal letter to Thomas Paine, Jefferson objected to entanglement in European interests:

"Determined as we are to avoid, if possible, wasting the energies of our people in war and destruction, we shall avoid implicating 
ourselves with the powers of Europe, even in support of principles which we mean to pursue. They have so many other interests different from ours, that we must avoid being entangled in them."

In his message of October 17, 1803, Jefferson developed the thought of the singular blessing of our detached situation:

"Separated by a wide ocean from the nations of Europe and from the political interests which entangle them together, with productions and wants which render our commerce and friendship useful to them and theirs to us, it can not be the interest of any to assail us, nor ours to disturb them. We should be most unwise, indeed, were we to cast away the singular blessings of the position in which nature has placed us, the opportunity she has endowed us with of pursuing, at a distance from foreign contentions, the paths of industry, peace, and happiness, of cultivating general friendship, and of bringing collisions of interest to the umpirage of reason rather than of force."

John Adams represented the same policy, objecting to becoming a make-weight in the European system, as is shown in his special message of May 16, 1797, in which appears, probably for the first time, the phrase, "political system", which later became famous :

"Although it is very true that we ought not to involve ourselves in the political system of Europe, but to keep ourselves always distinct and separate from it if we can . . However we may consider ourselves, the maritime and commercial powers of the world will consider the United States of America as forming a weight in that balance of power in Europe which never can be forgotten or neglected. It would not only be against our interest, but it would be doing wrong to one-half of Europe, at least, if we should voluntarily throw ourselves into either scale."

The conviction of Washington, Jefferson, and Adams, that the United States ought to keep out of the contests of European nations was obvious common sense. The Union was still new, weak, and imperfect; it had no army, hardly a national armed vessel, and little of the material of war. In population the United States in 1790 was as large as Switzerland is today; as a military and naval power her relative place among nations was lower than the present Argentine Republic. The United States was one of the small powers of the late eighteenth century. 
Even when, in 1793, the European wars extended to American waters, and English and French vessels captured merchantmen and fought each other near to the United States, or even inside our water boundaries, the policy of neutrality was necessary and successful. The United States rendered a service to mankind by clearly insisting on the rights of neutral trade. When the European war broke out again in 1805 with great violence, President Jefferson still stuck to the belief that the United States must not be a party to European wars; and nothing but the lack of statesmanship in Great Britain allowed this country to drift into the War of 1812 .

\section{COUNTER DOCTRINE OF EUROPEAN ALOOFNESS}

In course of time the Doctrine of Isolation was extended to cover the converse principle that it was the province of the United States to keep Europe from altering the conditions of America. Hamilton in the Federalist uttered the daring prediction that

"By a steady adherence to the Union, we may hope, ere long, to become the arbiter of Europe in America, and to be able to incline the balance of European competitions in this part of the world as our interest may dictate."

The next logical step would have been to assert that the Americas had reached a permanent status of division of territory; but transfers of territory were still going on. In 1795 Spain ceded Haiti to France. During the Napoleonic wars the sea power of England enabled that power to make further shifts of the islands, and in 1814 to secure certain Dutch possessions in Guiana. As will be shown in the next chapter, wholesale transfers of Spanish and Portuguese colonies were violently attempted by Napoleon. In the midst of this process, the United States was in no position to protest against the English taking French West India islands, or the Russians coming in on the far Northwest.

Instead of defending the status quo therefore, the policy of the United States from 1789 to 1823 was to alter the ownership of territory to her own advantage. In 1795 Spain accepted the thirty-first parallel as the boundary line on the east of the Mississippi, thus acknowledging the first inroad made by the 
United States upon territory claimed as a part of the Spanish Empire. By the same treaty the United States obtained the coveted navigation of the Mississippi, which was expected to be, and proved to be, a long step toward possession of the whole course of that river.

In 1802 the United States for the first time realized the danger to herself that might come from the transfer of territory from a weaker to a stronger European power. Hence, on the news of the Treaty of San Ildefonso, in 1800, between Spain and France, Jefferson wrote the oft-quoted warning (April 18, 1802):

"The cession of Louisiana and the Floridas by Spain to France works most sorely on the United States. . . . It completely reverses all the political relations of the United States, and will form a new epoch in our political course. ... There is on the globe one single spot, the possessor of which is our natural and habitual enemy. It is New Orleans. ... France, placing herself in that door, assumes to us the attitude of

France must be kept out of Louisiana even by a British alliance. defiance. Spain might have retained it quietly for years. . . . The day that France takes possession of New Orleans fixes the sentence which is to restrain her forever within her low-water mark. It seals the union of two nations, who, in conjunction, can maintain exclusive possession of the ocean. From that moment, we 3 must marry ourselves to the British fleet and nation. We must turn all our attention to a maritime force, for which our resources place us on very high ground; and having formed and connected together a power which may render reinforcement of her settlements here impossible to France, make the first cannon which shall be fired in Europe the signal for the tearing up any settlement she may have made, and for holding the two continents of America in sequestration for the common purposes of the United British and American nations."

A vivid interest in the subject was shown by the people of the United States; and they backed up Jefferson's policy. Napoleon, though quite uninfluenced by any wishes of the American people and their president, had reasons of his own for transferring a territory for which he never paid, and which he could not have held. Practically, the annexation of Louisiana was an enormous expansion of the United States at the expense of Spain. Once started in this direction, two other Spanish provinces seemed desirable. West Florida was an- 
nexed by military force in several installments from 1810 to 1814. East Florida was ceded by the treaty of 1819 and by the Spanish ratification of 1821 .

Nothing could be more certain than the stout defense by the United States of all this annexed territory, with all the strength and resources of the country. The administration felt strong enough to refuse the boundaries claimed by Spain in West Florida and Texas, and to make the most of the so-called "purchase" of East Florida from an unwilling vendor. This annexation policy, at the expense of Spain, was formally defended by American statesmen on the ground that it had nothing to do with Europe. In a conversation of John Quincy Adams with the English Minister, Stratford Canning, October 2, 1820, he spoke of the position of the United States.

"The general extra-European policy of the United States... which they had always pursued as best suited to their own interests and best adapted to harmonize with those of Europe. This policy had also been that of Europe, which had never considered the United States as belonging to her system."

July 5 of the same year, Adams wrote to Middleton, our Minister to Russia, against entanglements with Europe:

"To stand in firm and cautious independence of all entanglements in the European system, has been a cardinal point of their policy under every administration of their Government, from the peace of 1783 to this day."

\section{EXPANSION INTO WILD TERRITORY}

All the original English colonies, from Maine to the Carolinas, were settled in territory occupied by uncivilized people, except New York, and the former Swedish province of New Sweden, which were the first-fruits of conquest from Holland in 1664. All the rest of the territory occupied by the United States down to 1823, was made up either of pre-Revolutionary British colonies, or of American conquests or purchases from other nations. The one exception to this statement is Oregon. Jefferson's suggestive mind early saw the significance of the Pacific Coast, and as soon as he became president he took steps to send out the exploring party of Lewis and Clark. He was doubtless aware that the Russians had some trading- 
posts on that far-distant shore; probably he knew that (July 8, 1799) Czar Paul had granted a charter to the Russian-American Company, giving it jurisdiction as far south as the fifty-fifth parallel of north latitude, with permission to establish posts further south in territory not occupied by other powers. Lewis and Clark found no Russians on the Columbia in 1806; and their exploration, combined with Captain Gray's discovery of the river in 1792, gave the presumption of title to the United States, as the first civilized country to discover a region inhabited only by wild men.

These claims collided with those of Spain and of England and were not strongly pushed, till in 1811 John Jacob Astor sent out an expedition by sea and by land to found a tradingpost at Astoria, at the mouth of the Columbia. His post was taken by the British during the War of 1812 , but was restored in 1818; and the British and American governments made an agreement for temporary joint occupation of the territory disputed between them. This was the first and (with the exception of Samoa) the last agreement of the United States for joint occupation of disputed territory with any European power.

The Russians had shown a friendly spirit toward America. Alexander I entered on a personal correspondence with Thomas Jefferson; and John Quincy Adams was Minister to Russia during Napoleon's invasion of 1812. At the same time, they began to plant trading-posts down in the Spanish territory. In 1813 they built such a post at Bodega Bay which was main.tained until after 1840. The Russian line of fifty-five degrees north was far beyond any territory desired by the United States; but the country was aroused by the news of another ukase, issued by the Czar of Russia September 7, 1821, containing the following Russian territorial claims:

"The pursuits of commerce, whaling, and fishery, and of all other industry, on all islands, ports, and gulfs, including the whole of the northwest coast of America, beginning from Behring's Straits, to the $51^{\circ}$ of northern latitude, also from the Aleutian islands to the eastern coast of Siberia, as well as along the Kurile islands from Behring's Straits to the south cape of the Island of Urup, viz: to $45^{\circ} 50^{\prime}$ north latitude, is exclusively granted to Russian subjects. It is therefore prohibited to all foreign vessels, not only to land on the coasts and islands belong- 
ing to Russia, as stated above, but also to approach them within less than an hundred Italian miles. The transgressor's vessel is subject to confiscation, along with the whole cargo."

By this time the Spanish claims in this part of the world had been extinguished by the treaty of 1819 with the United States. That left the three claimants, - the United States, Great Britain and Russia, - facing each other. It was a bold step on the part of the United States to insist that her title to Oregon was not only as good as that of Great Britain and Russia, but better than anybody's; and that all other nations must expect to be shut out from the water front north of California, which gave access to the mighty interior. Yet-a protest against the Russian claims appears in the same document as Monroe's declaration on intervention, and has ever since been carried as a fundamental part of the Monroe Doctrine.

\section{THE UNITED STATES AS AN AMERICAN POWER IN 1823}

The forty years between the Treaty of Peace of 1783 and the Monroe Doctrine of 1823 saw vast changes in America. The United States began as a feeble little power with less than four million people, occupying 892,000 square miles, most of the population lying near tidewater. In 1823 there were 10,000,000 people settled upon the area lying south of the Lakes and east of the Mississippi and holding 1,792,000 unquestioned square miles of territory which reached to the summit of the Rocky Mountains. Beyond was the immense region of Oregon, which at that time meant the stretch north of California and south of Alaska between the summits of the Rocky Mountains and the Pacific. All the acknowledged accessions of the United States so far had been at the expense of Spain, but the territorial ambitions of the United States extended northward over Canada, and southwestward into Texas. Some imaginations could even conceive of California as a future part of the United States.

In this period the situation of the United States in the family of nations had much improved. The Republic had endured for forty-seven years and seemed likely to last indefinitely. The East and West were linked together by many highways, including the government Cumberland road, and the Erie 
Canal was nearly completed between tidewater and Lake Erie. Humiliating defeats in the land campaigns of 1812 had taken away the expectation of the conquest of Canada; but the American victories at sea inspired a wholesome respect for this country. In the minds of European statesmen, and particularly of English statesmen, the United States was the one rapidly growing and expanding nation of the New World; she had already acquired territory enough for the homes of several hundred million people. Though weak in a military sense, the United States was recognized as a great potential power. Furthermore, the United States as an arbiter had something new to decide, inasmuch as by 1823 the former place of Spain in America was taken by new revolutionary and virtually independent Latin-American governments. 
Chapter .II

\section{THE NEW LATIN-AMERICAN POWERS 1783-1823}

\section{EUROPEAN COLONIES IN AMERICA IN 1783}

When the Treaty of Peace of 1782-83 recognized the United States as an independent nation, there were five other blocks of American territory held by strong nations: (1) The British possessions and claims north and northwest of the United States, and in the West Indies. (2) The French in the West Indies. (3) Russia in the far Northwest. (4) Portugal in eastern South America. (5) Spain, which occupied the entire coast line from the St. Mary's River in Florida along the Gulf of Mexico, the Caribbean Sea, the Atlantic (with the exception of Brazil), and the whole coast of the Pacific from Cape Horn to the archipelago of the Northwest Coast.

All these colonies were held on about the same tenure. Every country settled the affairs of its colonies principally in the European capitals; even in the English St. Lawrence and West Indian colonies the people had very little part in their own government. Every home country attempted to restrict the trade of its colonies to its own vessels and its own ports. Even France, who aided the United States to gain independence, gave no privileges in the West Indies.

In 1783 the Spanish colonies were divided into several groups. (1) Immediately alongside the United States were Florida, a narrow strip which cut off the southern States from direct access to the Gulf, and Louisiana, which was a barrier across the mouth of the Mississippi. Both of them had a scanty population, and in Louisiana the Spaniards were only an offcial veneer. Either province might have been rushed at any time by a few thousand men from the North. (2) The populous Kingdom of New Spain contained well-built cities, a uni- 
versity, and an aristocracy of wealthy land-owners and silver kings. To Mexico also adhered the three outlying districts of Texas, New Mexico, and California. But Texas was in a desolate condition, because of the inroads of Comanches and other fierce Indian tribes; and New Mexico had never been prosperous. California in 1783 was developing the mission system, which rose to a prosperous condition, but later collapsed. Texas, New Mexico, and California were all at great distances from the United States and had been visited by few English-Americans. (3) The South American group of Spanish colonies, with which the United States had little touch. (4) The Spanish West Indies, which were near at hand; but direct trade was officially forbidden to the British colonjes or to the United States.

It has long been fashionable to dwell upon the iniquity and tyranny of the Spanish government in the New World. This belief that the Spaniards were inherently cruel to all the natives and harsh to their own people had great effect in bringing .on the Spanish war of 1898 and the annexation of the Philippines and Porto Rico. The truth seems to be that the Spanish government of the colonies was rather stupid than wicked. Easy-going modern writers, by mixing up practices and incidents of the sixteenth century with those of the nineteenth, leave an impression of systematic repression, both of the natives and of the Spanish race. Nevertheless the Spaniards in Mexico or Buenos Ayrès, were probably better off and less burdened by meddling officials than Spaniards in the home country. Disturbances were few. The Antiquera rising in 1781 and the Tupac-Amaru rebellion in Peru in 1780 were almost the only formal revolutions. The Spanish colonies were more orderly than the English colonies at the same period. The Indians were oppressed and made serfs, but in the great period of Spanish rule they were not enslaved. Outside of Cuba and Porto Rico the Spanish held few of the negro slaves, who at the same period formed a sixth of the population of the United States. The Spaniards built cities, wharves, roads, bridges, splendid cathedrals and mission churches. Their sympathy with the natives was shown in the practical way of consorting with them and raising up families of mixed blood.

The principal grievance of the Spanish colonies was in matters of trade. They complained of the monopoly of the Cadiz 
ship-owners and of the restrictions on commerce from one colony to another. During the American Revolution some of those grievances were redressed; and, with or without the knowledge of the Spanish colonial authorities, there was always a contraband trade with their English colonial neighbors. This trade relation to the West Indies was one of the factors in the growth of a feeling of special interest by the United States. The English allowed a lively commerce between their West Indies and the United States, but only in British or colonial ships, which was long a grievance of the Republic. The Spaniards usually allowed no such trade, even in Spanish ships, but nevertheless it always went on in American vessels.

\section{RACE ELEMENTS IN LATIN AMERICA}

Many people in the United States appear to have supposed that the population of Latin America was substantially Spanish, just as the population of the United States was then substantially English. The Latin American revolutionists received and sometimes invited Englishmen, Frenchmen, Irishmen, and North Americans to join them, with the result that McGregors, and Lynches and Cochranes became generals, statesmen, and heavy property owners, but the Celts and Anglo-Saxons were few. Though the common language was Spanish, probably two thirds of the population could hardly understand a word of it. The Spanish law, which was common to all the colonies, was later modified by the influence of French jurisprudence. Then, as now, the obvious and direct intellectual relations of Latin America were with Europe rather than with the United States.

The population was in fact made up of three elements: (1) The Iberians or native Spaniards with the "Creoles" born of the Spanish race in America; (2) mixed SpanishIndian bloods - commonly called mestizos; (3) the native Indians. In Cuba, Porto Rico, and Brazil was found a fourth element of mulattoes and negroes. The native Spaniards had most of the offices and honors in the colonies; as late as the Cuban insurrection of 1895, the "Peninsulars" looked upon themselves as superior to their own kinsmen and sons born on American soil. As for the Creoles, let the modern jurist Alvarez speak: 
"The creole element, the only thinking part of the population, felt the injustice with which the mother country treated its colonies. The 'élite' of this class, instructed by travel and the perusal of the philosophical writings of the eighteenth century, took advantage of the embarrassing position in which Spain found herself because of the Napoleonic wars, and followed the example of the United States, dragging the entire creole element into a movement of emancipation."

A contemporary Peruvian writer says of these Americanborn Spaniards :

"The creoles are possessed of an independent spirit; and they hate and despise the Spaniards : they form by far the most enlightened portion of the community. Their master passions are the love of knowledge, and a luxurious and splendid mode of life, and they spare no pains to furnish themselves with books, sumptuous furniture, and articles of luxury.... Gold and silver are employed profusely in fitting out the trappings of their horse equipage, and in furnishing their houses; the vessels in the most common use, of the kitchen and bed-chamber, being made of silver. . . . They have tables of solid silver, and their window curtains, which are of velvet, are fringed with gold lace. Their tables are covered with a great profusion of dishes, cooked after the French and Spanish mode. ... This mode of life, which is owing to the generous and hospitable character of the creoles, who are born to independent fortunes, often degenerates into wasteful prodigality and dissipation."

Admiral Chadwick has recently taken the position that the whole expression "Latin America" is an error. He holds that the native Spaniards and Portuguese spring to a large degree from the Berber race of north Africa, tempered with infusions of Roman and Germanic strains; and that race, both in Spain and in the New World, shows the unrest and impatience of restraint which would be expected of nomads. Whatever the soundness of this observation, there can be no doubt that the Indian element is far larger than the European in all the Latin-American states except the Argentine; and that the Indians and many of the mixed bloods are still ignorant, uneducated, and unable to understand or support genuine popular government. 


\section{UNEASINESS IN THE SPANISH COLONIES (1783-1807)}

The Spaniards were a stiff-necked people, slow to learn the lesson of giving way gracefully to forces too strong for control, and their colonial policy remained harsh. Still there is no evidence to show that the Spanish colonists would have followed the revolutionary example of the thirteen United States, but for the terrible upsetting of Europe by the French Revolution, which convulsed Spain and threw the colonies into confusion. The Spanish royal house was a branch of the French house, and the two powers had for a century been in close relations of friendship and often of formal alliance; Spanish royalty was bound to oppose the French Revolution. In 1793, therefore, Spain went to war against France. Two years later Spain came under the influence of reorganized France. The fate of a weak ally overcame Spain, whose fleet was defeated by the English in 1797. In 1800 Spain was compelled to cede Louisiana to Napoleon; in 1805 she joined her fleet with that of the French in the disastrous sea fight of Trafalgar; and in 1808 Napoleon dispossessed the Spanish royal family, and so far as he could took possession of the whole Spanish Empire.

The Spanish colonists could well understand the weakness of their home government of which the French alliance was a proof. They could understand also the diplomatic defeat of Spain in the Nootka Sound Convention with England in 1790. By this treaty, forced almost at the cannon's mouth, Spain acknowledged that Great Britain had an equal right to touch and trade on the Northwest Pacific coast; and England was thus admitted into the rivalry of Oregon. A few months later Francisco de Miranda, a born Venezuelan, came forward as the first professional Latin-American revolutionist. He drew up and submitted to Pitt, the British Prime Minister, a plan for "Freedom and Independence" under a SpanishAmerican Confederation, at the head of which was to be an hereditary "Emperor." He expected the English to drive out the Spaniards, and then to turn the colonies over to their inhabitants. He even tried to draw the United States into this scheme, but Washington and his supporters could not be interested. Miranda then attempted to arouse France, who through Minister Genêt, attempted to reconquer Louisiana 
(1793). In 1798 the indefatigable Miranda approached President Adams with a plan for an expedition to be organized in the United States intended to bring about a guaranteed independence. Hamilton explained that the plan was -

"Independence of the separate territory under a moderate government, with the joint guaranty of the co-operating powers, stipulating equal privileges in commerce."

Though the United States declined to take any part in a revolutionary movement which the Spanish colonists showed no signs of approving, suggestions were abundant that sooner or later the Spanish Empire would break up. As early as 1792 Hamilton predicted that war with Spain would result from territorial controversies; although Jefferson, in an instruction of July 28,1791 , to Short, our Minister in Spain, wrote on our attitude toward designs on the West Indies:

"Whenever jealousies are expressed as to any supposed view of ours, on the dominion of the West Indies, you cannot go farther than the truth, in asserting that we have none. If there be one principle more deeply rooted than any other in the mind of every American, it is, that we should have nothing to do with conquest."

The treaty of 1795 between Spain and the United States settled the disputed Southwest boundary and postponed the inevitable clash between the two countries.

This indifference of Jefferson to the fate of Spanish America received a severe shock in the Louisiana controversy. For the first time the United States realized that the transfer of an American colony from one European power to another might be very unfavorable to the United States. Hence Jefferson's threat of alliance with England and war upon France. To be sure, Louisiana was not a true Spanish province: most of its inhabitants spoke French and sympathized with France; and they cheerfully accepted their incorporation into the Union in 1803. New Orleans became the outlet port for most of the western United States. In 1806 a formal attempt was made by Miranda to revolutionize his native country, Venezuela. He consulted with Jefferson and Madison and supposed that they approved his plan. He fitted out a ship, enlisted two hundred men in the United States, and for a short time held a little area in Venezuela, and received some evidences of 
sympathy from the people. When he was defeated the United States took no responsibility for the affair; and it was plain that Spanish America at that time had no thought of being anything other than Spanish.

\section{FIRST SPANISH-AMERICAN REVOLUTIONS (1806-1812)}

Probably the Spanish colonies would eventually have wearied of the inept government of Spain; but the process was hastened by many years through the ambition of Napoleon. In 1807, after conquering Prussia and coming to an understanding with Alexander of Russia, he turned his attention southward. He bribed the King of Spain (with a promise of half of the Portuguese colonies) to allow him passage to Portugal. In November, 1807, he occupied Lisbon and the royal Portuguese family fled to Brazil. Next, Napoleon carried out a part of his plan which had not been revealed to Spain. The French army was sent to Madrid and in April, 1808, King Charles and his son Ferdinand, heir to the throne, were made prisoners, and under pressure formally transferred their royal rights in Spain and the colonies to Napoleon. The purpose of the conqueror was clear: he had failed to acquire Louisiana; but Cuba, Mexico, and the South American provinces would be his recompense.

Meanwhile, the English had been trying to forestall Napoleon by accepting Miranda's idea of setting the colonies free, with the expectation of annexing them to Great Britain. In 1806 British naval expeditions were sent to Chile and to the La Plata, where Buenos Ayres and Montevideo were occupied. The Spanish colonists rallied to the defense of their country and the English were driven out. When a commissioner appeared demanding the transfer of the region to the French, the colonists refused this offer of benevolent assimilation also; and from that time to the present day Buenos Ayres has been substantially independent of Spain.

From 1808 to 1814 the Kingdom of Spain was in a continuous revolt against the new régime, especially against King Joseph Bonaparte, who had been designated by his brother to be nominal sovereign. The Spanish colonies were left to themselves in this unhappy period of confusion. In 1809 revolution broke out in Peru, Mexico, and other Spanish colonies. On 
the other side, the enemies of France had vague plans for creating a Spanish-American kingdom, probably under a Bourbon prince.

The only other thing resembling a regular Spanish-American government by the revolutionists was in Venezuela, where, in 1811, the people took the critical step of declaring independence of all Spanish authority. Counter revolutions were put down. Paper money was issued; a federal constitution was adopted. For a time Miranda became dictator. Another of the leading figures in this revolution was Simon Bolivar, who continued a desultory fight after his friends had surrendered to Spain. A revolt in Mexico under Hidalgo was put down with great severity.

\section{SYMPATHY OF THE UNITED STATES}

For many reasons the United States was deeply interested in this unsuccessful attempt at revolution; and for the first time Cuba emerged as an object of national desire. During the confusion of European affairs, direct Cuban trade was allowed and proved so profitable that Jefferson for the moment thought of securing that island as the share of the United States in the breakup of the Spanish colonies; he would at the same time have annexed Canada. "Then," said he, "we should have such an empire of Liberty as she has never surveyed since the creation." Nevertheless he drew a limit to his own ambition :

"I would immediately erect a column on the southernmost limit of Cuba, and inscribe on it a ne plus ultra as to us in that direction."

Jefferson a few weeks earlier had gone out of office; and Madison, his successor, was confronted with a little revolution in Spanish West Florida. In January, 1811, he laid down in a message to Congress the highly significant principle of special interest in West Florida :

"The United States could not see, without serious inquietude, any part of a neighboring territory, in which they have, in different respects, so deep and so just a concern, pass from the hands of Spain into those of any other foreign power." 
On March 3, 1811, Congress passed a formal resolution almost in the President's words. This official statement of public policy antedates Monroe's by thirteen years; and includes the principle that American territory is not to be transferred from one European power to another.

A curious paper, over the signature of General James Wilkinson and addressed to Jefferson, under date of 1808, exists in the archives of the State Department. Wilkinson there predicts that "Mexico, Peru, and Cuba [would be] formed into independent states"; he points out that they must not be allowed to pass under the domination of European powers other than Spain; and he suggests a great Pan-American combination of States:

"The grandest and most charming spectacle of Nature. The liberation of the American continent from the shackles of European government and the Nations of the West forming a distinct community, connected by the bonds of friendship and mutual interests, and united for their common protection, defense, and happiness."

As for trans-Atlantic relations, he would simply cut them off, commerce and all. It seems likely that Jefferson was somewhat influenced by this memoir in writing to Governor Claiborne, of Louisiana, October 29, 1808, with reference to the revolt of the Spanish colonies and the exclusion of European influence from North America:

"If they succeed, we shall be well satisfied to see Cuba and Mexico remain in their present dependence; but very unwilling to see them in that of either France or England, politically or commercially. We consider their interests and ours as the same, and that the object of both must be to exclude all European influence from this hemisphere."

\section{PRELIMINARIES OF RECOGNITION}

In many other ways the United States showed a lively sympathy in these revolutions; and from the beginning to the end of the French domination in Spain she declined to recognize the French kingdom there. Madison, in 1811, in a message to Congress relative to the Latin-Americans spoke of our special interest: 
"An enlarged philanthropy and an enlightened forecast concur in imposing on the national councils an obligation to take a deep interest in their destinies, to cherish reciprocal sentiments of good will, to regard the progress of events, and not to be unprepared for whatever order of things may be ultimately established."

This passage was understood to refer to the declaration of independence of Venezuela, and it is probably the first suggestion that the United States expected to see sister American states arise. A revolutionary agent from Mexico was received by Secretary Monroe at the State Department in 1811 ; and Joel Poinsett and Alexander Scott were sent as special agents to Buenos Ayres and to Venezuela with special instructions. This is virtually the first official commercial relation with Latin America :

"The real as well as ostensible object of your mission is to explain the mutual advantages of commerce with the United States, to promote liberal and stable regulations, and to transmit seasonable information on the subject."

Poinsett even took command of Chilean revolutionists for a short time and compelled the Spanish authorities to release American vessels that had been detained.

A palpable advantage of these revolutions was the opening up of direct commerce with the revolutionary and Spanish ports. Santo Domingo also became a center of American commerce. The island, which since 1795 had been wholly French, was overwhelmed by a negro insurrection; and in 1798 Toussaint L'Ouverture declared himself an independent sovereign and the United States sent out a consul.

Havana also became a resort for American vessels. Indeed, ever since the annexation of Louisiana there had been hints that Cuba ought to be the next annexation. Jefferson wrote on this subject to President Madison in 1809 against any annexation which required a navy:

"It will be objected to our receiving Cuba, that no limit can then be drawn to our future acquisitions. Cuba can be defended by us without a navy, and this develops the principle which ought to limit our views. Nothing should ever be accepted which would require a navy to defend it. 


\section{SECOND ERA OF AMERICAN REVOLUTIONS (1814-1821)}

During this period the Spanish colonies were left to themselves; but the royalists in those colonies were organized by viceroys and others who considered themselves still representatives of the genuine Spanish government. In 1812 a national constitution was framed by the patriots in Spain, and in 1814 the colonies were invited to send representatives to the Cortes, which was substantially the patriot government. With the aid of the English army the French were driven out of Spain; and Ferdinand came back as King. A reactionary through and through, he did his best to restore all the abuses of the old government. To the colonies, which had tasted the sweets of free trade and some control over their own affairs, he sent a Spanish fleet with ten thousand men and no suggestion of home rule. The Cadiz merchants had protested that free trade for the colonies -

"Would be the ruin of Spain and the destruction of all order, all morality, all religion, and all society."

Most of the colonies yielded except Buenos Ayres, which, on July 9,1816 , formally declared the province to be independent. This was the first actually independent LatinAmerican state; and its success is due to the genius of General San Martin, a native Spanish-American who had served in Spain. For some years he had been raising an army in the interior, and in 1817 he crossed the Andes and defeated the Spaniards there; in 1818 Chile was proclaimed independent. He coöperated with Lord Cochrane, an Englishman who became the naval commander of Chile. He pushed northward into Peru, where he defeated the Spaniards, and independence was proclaimed July 5, 1821. A year later Bolivar came marching down southward through the wilderness; and San Martin, after two brief conferences withdrew, leaving the field to his rival. Though he lived nearly thirty years longer, he took no part in the affairs of South America. Apparently he dreaded a civil war; but his withdrawal gave strength to the disruptive forces in Latin America. Bolivar, who had operated as a revolutionist in Venezuela, in Haiti, and in Colombia, was a Venezuelan by birth, and a man of vigorous, though 
bombastic,. character. In one of his many proclamations, he declared that:

"Venezuela is resolved to bury herself in her ruins, though Spain, Europe, and the whole world should come to reduce her to the Spanish yoke.”

While San Martin and Bolivar were slowly uncoiling the forces of Spain, a second revolution broke out in Mexico in 1816. For a time subdued, it gained ground till by the socalled Treaty of Cordova in 1821, an effort was made to hold Mexico to the Empire as a separate kingdom. The Spanish Cortes, representing the intense national spirit, refused to approve; and the Mexican patriots therefore declared themselves to be independent. In May, 1822, Iturbide, who had begun his career as an officer in the Spanish army, named himself Emperor of Mexico. Spanish garrisons remained in Vera Cruz and in some of the South American ports, where they could be reached by sea; and Cuba and Porto Rico had not felt the flame of revolution. Otherwise the great SpanishAmerican empire was absolutely destroyed. Brazil, which had been for a time the seat of the Portuguese government, followed the example of the Spanish colonies by setting up a new independent empire under Dom Pedro in 1822. The royal government, which had now returned to Portugal, was obliged to accept this state of facts, and Brazil was added to the group of American states.

\section{NEUTRALITY OF THE UNITED STATES (1814-1822)}

During this crisis Monroe became President, March 4, 1817 ; and John Quincy Adams was designated as his Secretary of State. Never till the present decade has the United States had such a glorious field for diplomacy; in Europe a syndicate of great powers undertook to rule the world; in America a complexus of feeble powers looked to the United States for sympathy, commerce, recognition, aid, and comfort. At the same moment the Oregon question was presented in a new form, through the preposterous claims of Russia; and our relations to Florida were such as to make necessary a treaty with Spain for its cession, as the alternative of war. In such troubled 
seas it was hard to keep an even keel, and the genius of the greatest secretary who has ever sat in the State Department, except perhaps John Hay, and the experience and judgment of President Monroe, were both tested to the utmost.

At last the ground was prepared for a distinct American policy on the part of the United States. The contest of the Latin-Americans had been long and uncertain, but no more so than the American Revolution. The resulting states were weak and disorganized, just as the States of the Union had been at the end of their war with England. Nearly all the new governments were nominally republics, and they paid the United States the compliment of imitating her Federal Constitution. A warm personal sympathy in the United States with American brothers engaged in founding American states was natural, and was certain to affect the administration and Congress.

From the beginning this friendly spirit was tried by the Latin-American brothers. The administration issued what was practically a proclamation of neutrality, September 1, 1815 ; and a second neutrality act was passed in 1817, which restrained the fitting out of revolutionary vessels in American ports. So far did the spirit of neutrality go that one of the Spanish viceroys in 1821 was granted an asylum on board a United States man-of-war on the Pacific Coast. Filibusters were arrested and imprisoned. Nevertheless, a considerable number of vessels were built in American ports for LatinAmerican governments which had no control of their own ports; and their cruisers and privateers were freely admitted into the United States. The Spanish government declared blockades which the United States refused to recognize as valid, and Spanish captures irritated the shipowners and gave rise to numerous claims.

This irregular warfare in the West Indies degenerated into piracy and an American fleet was sent to protect our commerce. Such difficulties, combined with illegal captures by the newly constituted governments, gave rise to the first block of claims by citizens of the United States against Latin America. Against Brazil, Chile, Colombia, Mexico, and Peru formal claims were lodged, and the foundations were thus laid for later controversies, negotiations, and arbitrations. 


\section{RECOGNITION OF THE LATIN-AMERICAN STATES (1816-1823)}

The key to the interlocked problem was our diplomatic attitude to the new Latin-American states. - Madison's policy was one of scrupulous neutrality; but, as the United States found out in 1861, to recognize the neutrality of a revolted community is to give it a status among nations.

The President's Proclamation of 1815 , and the respect paid to the Latin-American commissions to fighting vessels, practically amounted to a recognition of the belligerency of the new states, long before their independence was assured. The American courts in various cases recognized a state of war between Spain and the Spanish colonies. Almost from the first, however, the revolutionists made requests, almost demands, for complete recognition. In a despatch of December 10, 1815, Secretary Monroe predicted recognition:

"The revolution which is making rapid progress in South America becomes daily more interesting to the United States. From the best information that we can obtain, there is much cause to believe, that those provinces will separate from the mother country. Several of them have already abrogated its authority, and established independent governments. They insist on the acknowledgment of their governments by the United States, and when it is considered that the alternative between governments, which in the event of their independence would be free and friendly, and the relation which, reasoning from the past, must be expected from them, as colonies, there is no cause to doubt in which scale our interest lies."

When it came to action, Monroe, both as Secretary and as President, hesitated. The agents and would-be ministers who came to Washington took a high tone and sometimes tried to enter upon their functions without consulting the United States. Throughout the period of revolution, therefore, Monroe was cautious. At the other extreme stood Henry Clay, Speaker of the House, who began in January, 1817, to urge the immediate recognition of Buenos Ayres and other states. Partly to head off this movement the Administration followed the precedent of the sending of Poinsett and Scott, by commissioning Cæsar Rodney, Theodoric Bland, and John Graham to go to South America and report on conditions as they found them. The three commissioners reported each 
for himself in November, 1818, with considerable information on political, social, and economic conditions in Buenos Ayres and Chile. They inclined toward recognition of at least those two powers. A bevy of commercial agents was sent, especially Prevost and Forbes, who went out in 1820 and reported in 1822. It does not appear that these reports had much effect. John Quincy Adams, then Secretary of State, remarked in 1821 :

"I had seen and have yet seen no prospect that they would establish free or liberal institutions of government."

In 1810, one of the Spanish-American revolutions broke out in the little province of West Florida. That was one reason for the annexation of part of that district under a secret act of Congress of 1811. East Florida still remained Spanish, but in 1819 Secretary Adams secured a treaty by which the Spanish government agreed to cede East Florida for a price. The acceptance of that treaty was delayed in Spain and it was clear that recognition of the Latin-American states would be likely to prevent ratification. Therefore the President and Adams managed for a time to make head against the steadily increasing pressure of Clay and his friends. In public speeches, in amendments to appropriation bills, and in resolutions offered to the House, Clay urged that ministers be exchanged and that the United States commit itself to the independence and continuance of the South American Republics.

The delayed ratification was finally secured in 1821 ; and in his annual message of December and a special message of March 8, 1822, Monroe himself proposed recognition of Buenos Ayres, Colombia, Chile, and Mexico. Congress coöperated by passing an appropriation

"for such missions to the independent nations on the American continent, as the President of the United States may deem proper."

June 17,1822 , a representative was formally received from the Republic of Colombia. Within the next twelve months ministers were also sent to Chile and Buenos Ayres; and a few months later Brazil, Guatemala, and Mexico were recognized. Even then the United States did not think it proper to recognize the equally independent states of Haiti, Peru, or Paraguay. 
This formal recognition of the Latin-American states was another of the foundation stones of the Monroe Doctrine; for it clearly set forth the conviction that the United States knew her neighbors better than Europe knew them; and had a far greater interest in their welfare and continuance. How far did the United States really know and understand LatinAmerican neighbors? Long before the revolutions there, ship-masters and supercargoes had visited most of the ports, both on the Atlantic and Pacific sides, and brought home their impressions. The official reports of the special agents were crude and clumsy, but contained a considerable body of fresh information. Agents from the new republics did their best to infuse a sentiment of the virtue and capacity of their countrymen. Between 1815 and 1823 several serviceable books on Latin America were published, to appeal to American public opinion. Don Pazos, a Peruvian, cast his work into the form of Ietters on the United Provinces of South America, addressed to the Hon. Henry Clay (1819). Bullock's excellent book on Mexico was published in 1824. The publication of Alexander von Humboldt's profound researches in the New World began in 1807. The debates in Congress and the discussions in the newspapers kept the subject alive in people's minds. To be sure, now and then some observer laid bare the unpleasant fact that patriot leaders tended to become uncrowned despots; and to the end of the chapter, John Quincy Adams never had confidence in the Latin-Americans.

By 1823 the accumulated wealth shown in the splendid fittings and furniture of the well-to-do had to a large degree disappeared in the civil wars. Before the discovery of canning and refrigeration the only animal products exported were tallow and hides. Sugar and coffee were raised in the semi-tropical regions of Brazil and the West Indian islands. The most important export was specie: for hundreds of millions of dollars had been raised from the rich mines of the two Potosis of Peru and Mexico. The imports were manufactures and luxuries of all sorts, flour and other foodstuffs for the seaports. This Latin-American trade was felt to be valuable both by Europe and America; in it considerable American fortunes were made, as for instance that of Stephen 
Girard of Philadelphia. Most of this tr 'e from the United States was carried in the American vessels because the Latin-Americans were not skilled ship-builders and sailors. Notwithstanding their potential wealth, they had little capital, and were from the first dependent on foreigners not only for the development of their industries, but for loans to keep up armies and navies. As early as 1824 Mexico placed a debt of $\$ 32,000,000$ in Europe; and it does not appear that it has been paid down to the present day.

\section{POLITICAL CONDITIONS OF LATIN AMERICA IN 1823}

The desire to profit by the breaking of the Spanish commercial monopoly in America was undoubtedly one of the determining reasons for that interest of Americans in their neighbors which developed into the Monroe Doctrine. Another and powerful argument has already been mentioned - the Latin-American states with the exception of Brazil (and for a single year Mexico) formed republican governments, and in many cases federations, which were supposed to be on the model of the Constitution of the United States. The LatinAmericans did not readily read English, and their knowledge of free institutions appears to have come through the great documents of the French Revolution and the Spanish popular constitution of 1812. Their newspapers were of little significance. Their political experience was small. They had the Latin love of form and sonority, and abounded in proclamations. They followed the Spanish tradition of the significance of a law which nobody meant to obey. They loved rhetoric as a child loves honey. Take, for instance, the confidence expressed by Pazos in his letters addressed to Henry Clay.

"Of the absurdity of the efforts of tyrants to keep a nation of brave men in perpetual slavery, it is unnecessary to speak; and virtues of equally absurd is it to suppose that men who have the Patriots. unsheathed their swords against their Sovereign, will return, after ten years of revolution and bloody war, to the abject condition of colonies. Every day strengthens and emboldens the patriots, and brings tidings of their progressive success. Their resentment against their oppressors burns stronger and stronger as they approach, in imagination, the object of their desires; and the Spanish monarchy will probably never be so weak as at the 
present time, both in the old world, and in the new. It stands like a blasted oak upon the barren heath, whose branches are dropping off, one after another, and whose decayed and sapless trunk will be prostrated to the dust, by the first rude blast of popular fury."

With genuine enthusiasm they endowed themselves with the machinery of popular government, and early developed a class of writers on public and international law. By the middle of 1823 Spanish dominion had actually ceased, except in Cuba, Porto Rico, and a few seaports. What at a distance appeared to be constitutional governments, had been established in most of the Latin-American countries; and the United States by formally recognizing the stronger ones committed herself to an official belief that all these powers were, and of right ought to be, free and independent states. The new states possessed capitals, written constitutions, armies, and a diplomatic service. They went through all the forms of national existence. So far did the sympathies of the Americans extend that there was even a suggestion of taking one of the new-fledged chickens under the national wing. The former vice-royalty of Guatemala broke up into five little states, one of which, El Salvador, in 1822 sent commissioners to Washington to offer annexation.

\section{POSSIBILITIES OF LATIN-AMERICAN UNION}

To the people of the United States it seemed strange that sister colonies, which had in common gone through the purifying fires of revolution, should fail to combine and make one strong American state. A suggestion in that direction appears in a "Declaration of the Rights of the People of Chile", issued in 1810 , which set forth that:

"The day when America united in a Congress, whether of the Nation or of its two continents or of the South, speaks to the rest of the Earth, its word will be respected and its resolutions contradicted with difficulty."

This was a favorite idea of Bolivar's. The Central American states formed a temporary federation in 1824, and in the same year Mexico adopted the federal system. With the exception of Peru and Chile, most of the Latin-American coun- 
tries have since then been at one time or another parts of larger groups.

Such a general federation was not practicable in 1823 , both because of the vast distances between the various states, and because nobody could predict what would be the centers of population or the combination of units into communities which could serve as states. A certain kind of Pan-Latin-Americanism existed. There was a feeling of common origin and common destiny ; but after all, before a federation could come into existence, there were serious difficulties to overcome: the acts of a Congress would be made by the deputies from the larger states for the smaller; and any federal President must come from somewhere. Would Chile accept a Mexican President? As well go back to a Spanish sovereign!

What the people of the United States wanted was the growth of a nation or nations of kindred sentiments and aims. They looked on their neighbors as a kind of Latinized Englishmen. They could not realize that all the Latin countries at that time stood below the moral and economic standards of Europe and the United States. Most of the Latin-American populations lived in mountainous countries with little water communication, and infamously bad roads. The Plata, the Amazon, and the Orinoco were not developed. Between 1814 and 1823 eight Latin-American governments appeared - Buenos Ayres, Paraguay, Colombia, Peru, Chile, Central America, Mexico, and Santo Domingo. Of these, not one had, in 1823, achieved a democratic or a stable aristocratic government. Mexico was just getting rid of the temporary emperor, Iturbide. Brazil had a sovereign, with the monarchic traditions of Portugal. In all the other countries there were dictators, or small groups of rulers. Not a single state had fixed institutions, such as a permanent congress, an executive regularly chosen by the majority of votes, an established and independent system of courts. Not one had a well-organized financial system. One of the ablest of modern Latin-American writers, Alvarez, says of the disturbances in Latin America:

"This sudden political change, for which Latin America, because of its education, was not prepared, brought as an almost inevitable consequence civil wars, dictatorships and constant modifications of the fundamental ordinances of those countries in the first period of their independence." 
In the formation of a new government, hardly a leader, except San Martin, showed the qualities of patience, willingness to accept adverse judgments, and a love of peaceful methods. Several of the states had by 1823 already passed through cruel wars between factions of the same republic. This was the Latin America which furnished a new group of American states to be members of the family of nations. These were the countries concerning whom Monroe made public his doctrine in 1823. 


\section{Chapter III}

\section{EUROPE'S INTEREST IN AMERICA}

\section{$1814-1823$}

\section{INTEREST OF SPAIN AND FRANCE}

However warm and genuine the interest of the United States in the new America, it was a long time before American statesmen seized on the idea that their country was to decide the fate of the new neighbors. In fact, one reason why the United States and the new powers were drawn together was that they knew and feared the influence of Europe. Ever since the downfall of Napoleon, the future of America had been much in the minds of European statesmen, though they reached the question through their interest in Spain. In European councils there were no doubts as to the crimes of the Spanish colonists. The wars of liberation were looked upon as temporary defeats for Spain; declarations of independence were waste paper; recognitions by the United States were fanciful and unfriendly statements of a condition which did not exist. Peru, Mexico, and all the other self-styled states were still integral parts of the mighty Spanish Empire; and in due time the wanderers would be restored to their allegiance by a process the severity of which their children and children's children would never forget. In the revolted colonies there was a considerable element of born Spaniards and Creoles who pined for the old régime of order, peace, and profits.

Hence, in all the misfortunes of Spain at home, no party favored peace in America; none was willing to accept the independence of the colonies, even as a disagreeable fact. The king, the ministry, and the opposition agreed in holding on to the colonies. So long as they could, they sent troops and ships to reconquer their subjects. When that was no longer possible, they looked to other European powers to help them out. France, Great Britain, and Russia all had a stake in. 
America, and Prussia and Austria, though not directly affected by the controversy, sympathized with the efforts of the other powers to control the future of America.

For a short time France appeared as the patron saint of the royal interests in Spain. The King of Spain was a far-off cousin of the French Bourbon king, and there was a dim notion that the two nations ought to revive the Family Compact of a century previous. A more direct incentive was the French ambition for colonies. France came out of the Napoleonic Wars in the market for dependencies. Since the immense European annexations of Napoleon had all been lost, the restored Bourbon monarchy wanted to make a showing in foreign conquests. Eventually Algeria was selected as the place for expansion. In 1823, however, France hoped to expand in the West Indies; and the most available territory was Cuba. With a romantic disregard of the temper of the Spanish-Americans, the French royal Bourbon house evolved the idea that its younger branches might find thrones in LatinAmerican kingdoms, which would naturally rest under the shadow of France. To the French, therefore, recognition of the independence of new American states by the United States was nothing more than an attempt to prevent the natural development of French influence in America. France built a fleet and became the second naval power in the world. What more reasonable than that the chief Latin power should take charge of Latin America?

\section{INTEREST OF ENGLAND}

A third power was Great Britain, the greatest maritime nation of the world, then at a great height of power and prestige; and pushing hard for colonies and naval stations in all parts of the globe. For two and a half centuries Great Britain had been the enemy of Spain. Who pried off from the Spanish Empire Virginia, Jamaica, and other West India islands, British Honduras, the Carolinas, and, for a time, the Floridas? Who was the enemy that filched away Gibraltar in 1704? Who over and over defeated Spanish fleets during a century? Who humiliated Spain in the controversy over Oregon in 1790 ? By a strange change of conditions, during and after the Napoleonic Wars Great Britain became the inti- 
mate friend and protector of Spain. From 1808 to 1814 British armies were in the Peninsula fighting the French oppressors of the Spaniards. Thereafter the British were almost allies of the Spanish government. It was natural for Spain to appeal to Great Britain to "mediate" between thern and the colonies ; that is, to exert a moral pressure, with a view to bring about their return to allegiance.

The British government was not acting out of charity. The English looked on Spanish-American relations, however distressing, as an opportunity for new trade and influence. The commercial reason alone was enough to decide their position. The British had for ages chafed against the Spanish monopoly of the Spanish colonial trade; and the destruction of that monopoly opened up a new and valuable market. If the colonies went back, the Spanish Colonial System would return; and England could hardly protest, in view of the fact that she was maintaining a similar system in her own colonies. ? Another motive was the conception that the Spanish colonial and naval power had been a serious rival for three hundred years, and when it was cleared away England would have a freer hand in many directions. Spain had ceased to be a serious opponent in European affairs; the Spanish-American states were in no condition to defy Great Britain; why reunite those two elements; why re-create a Spanish world-power?

So far as territory was concerned, the English showed no desire to annex any part of this derelict empire, except the island of Cuba. The energies of Great Britain were engaged elsewhere. British expansion was then going on in South Africa and India, and was beginning in Australia and Canada. The English had the good sense not to meddle with conquests of Latin-American peoples who had no desire to enter the British fold and who gladly opened their trade to the greatest manufacturing and commercial power of Europe. At the same time, England was in a political combination with four other great powers which compelled attention to American affairs.

\section{THE HOLY ALLIANCE (1815-1822)}

Neither Spain, Great Britain, nor France could frame and carry out a policy of their own; for Europe from 1814 to 1823 was under the influence of the strongest and most effective 
international union which the world had ever known. This combination is commonly called the Holy Alliance, from a document which was not the official tie between the constituent states, but simply a statement of principles. The prime cause of the Holy Alliance was the existence of Napoleon after he had twice been overwhelmingly defeated and deposed. He was sent to St. Helena, as the state prisoner of Europe, there to muse upon his past greatness; but so long as he lived Europe suffered from the nightmare of a second return from exile. After his death in 1821 the combination gained strength, though it was then fighting a power greater and more lasting than Napoleon's, and that was the spirit of popular government.

The French Revolution had smashed the remnants of the old feudal system in most of Europe and substituted a régime of equal right before the law, which even Napoleon when he was the autocrat thought it unsafe to disturb. The idea of a right of participation by the people in their own government, which had been crudely developed by the French Revolution, was current in England; pushed its way into Germany; and reappeared under the Bourbon restoration in France. It appealed to some of the greatest statesmen of the time - Talleyrand of France, Alexander of Russia, Cavour of Italy. Yet, from 1818 to 1827, the guiding spirit of Europe was Prince Metternich, minister of Austria. To his mind the salvation of Europe depended upon the principle of "legitimacy."; that is, that nations were bound to obey their crowned kings, no matter what their character or behavior. The enemy of legitimacy in the French Revolution had been the Convention, chosen by the people; hence there ought to be no popular parliaments. The French Convention was brought in by revolution; hence revolutions must be headed off. Some states liked revolutions; hence strong and more virtuous states must take them in hand. Strong and virtuous states could act together only if united by a common understanding and common agreements; hence an organization of congresses of sovereigns and trusted counselors, which were held from time to time to decide the affairs of Europe. - Such was the system.

The official cornerstone of this far-sighted combination was a document drawn up in Paris, September 26, 1815, and signed 
by the sovereigns of Austria, Prussia, and Russia. The two themes of this document are both highly moral.

"The policy of the powers, in their mutual relations, ought to be guided by the sublime truths taught by the eternal religion of God

Religious basis of government. our Saviour . . the precepts of that holy religion, the precepts of justice, charity and peace...."

"The monarchs "look upon each other as brothers. . . . "They shall lend aid and assistance to each other on all occasions and in all places. ... Hence the sole principle of conduct, Mutual political insurance. be it between the said government or their subjects, shall be that of rendering mutual service, and testifying by unceasing good-will, the mutual affection with which they should be animated. Considering themselves all as members of one great Christian nation, the three allied princes look upon themselves as delegates of Providence called upon to govern three branches of the same family, viz.: Austria, Russia and Prussia.... All those powers who wish solemnly to make avowal of the sacred principles which have dictated the present act ... shall be received, with as much cordiality and affection into this Holy Alliance."

This appeal, which appears to have been drawn by Madame Krudener and pushed by the Czar Alexander of Russia, drew the taunts of the ungodly at the time; and Lord Castlereagh, the British Foreign Secretary, solemnly reported that Alexander had lost his mind. Nevertheless, the document, which John Quincy Adams afterwards called "a hypocritical fraud," was eventually signed by all the powers in Europe, except England, the Pope, and the Sultan of Turkey.

\section{WORK OF THE HOLY ALLIANCE (1815-1822)}

The real combining force was a very different document the Treaty of November 20,1815, by which the four powers, England, Prussia, Russia, and Austria, - agreed to act together in the restoration of France and the general conduct of European affairs. Three years later, France was allowed to join this combination, and for ten years the five powers ruled Western Europe with a rod of iron.

In this day of anxiety, when thousands of people look forward with keen desire to a European federation, it is important 
to point out the results of the rule thus established. Practically, the Holy Alliance was a machine for imposing the will of the large powers upon small powers; for nobody dreamed that it would interfere with the internal arrangements of any of the five Great Powers. There was no customs union, no common organ of action, no European citizenship. The real purpose was to prevent the breaking out of revolutions in small powers which might have an irresponsible hankering after a popular type of government. The real government was in the five sovereigns or their immediate advisers, acting through correspondence and occasional meetings.

These meetings were a feature of the whole system. The name Congress was applied to the assemblage at Vienna in 1814 which adjusted the boundaries of Europe. A sort of second session was held in 1815, which, among other things, drew up a form of confederation for Germany. One of the few generous acts of the Congress was a group of treaties for the neutralization of Switzerland, Cracow, and the Pope. When the system was in swing a custom arose of sending out from successive Congresses proclamations and statements of high moral principles. Thus, in the Congress of Aix-la-Chapelle, the Alliance announced peace as the object:

"Has no other object than the maintenance of peace and the guarantee of those transactions of which the peace was founded and consolidated.... The repose of the world will be constantly our motive."

In 1821 the Allies informed the world that they would allow no changes in government:

"Taken the people of Europe into their holy keeping and that, in future, all useful and necessary changes in the legislation and administration of states must emanate alone from the free will, the reflected and enlightened impulse of those whom God has rendered responsible for power."

The culmination was reached at the Congress of Verona, in 1822, which went so far that Wellington, the English representative, was instructed to withdraw, and would not sign the Treaty of November 22, 1822, which contained the following provisions : 
"ARTICLE I. - The high contracting powers being convinced that the system of representative government is equally as incomNo repre- patible with the monarchical principles as the maxim sentative of the sovereignty of the people with the divine right, government. èngage mutually, in the most solemn manner, to use all their efforts to put an end to the system of representative governments, in whatever country it may exist in Europe, and to prevent its being introduced in those countries where it is not yet known.

"Article II. - As it cannot be doubted that the liberty of the press is the most powerful means used by the pretended supporters No liberty of the rights of nations, to the detriment of those of of the press. Princes, the high contracting parties promise reciprocally to adopt all proper measures to suppress it, not only in their own states, but, also, in the rest of Europe.

"Article III. - Convinced that the principles of religion contribute most powerfully to keep in the state of passive obedience Support of which they owe to their Princes, the high contracting authority of the clergy. parties declare it to be their intention to sustain, in their respective states, those measures which the clergy may adopt, with the aim of ameliorating their own interests, so intimately, connected with the preservation of the authority of Princes ; . . ."

In the Congress of Verona the principal subject discussed was the status of Spain, including the future of the American colonies.

\section{INTERVENTIONS IN EUROPE (1818-1823)}

The activity of the Holy Alliance is not to be measured by its turbid documents, but by its unrighteous deeds. It made itself an instrument to crush out the progressive ideas which oontinued to crop out in the small German states. It interested itself in punishing German students for a celebration in the ruined castle of the Wartburg; it worked against constitutional reforms in the German states. Most of all, it used its enormous collective power to crush revolution in Portugal, Piedmont, Naples, and Spain. The doctrine that the great powers must use force against the small powers first clearly appeared at the Congress of Aix-la-Chapelle in 1818. In 1820, the people of Naples rose against one of the worst kings who has ever sat upon a throne, and compelled him to take oath to a constitution. In the same year came a mutiny of Spanish soldiers who were 
lying in the harbor of $\mathrm{Cadiz}$ - waiting to be sent over to fight the Spanish revolutionists. The movement quickly spread into a revolution; King Ferdinand, like his Neapolitan kinsmen, bent to the storm and accepted a parliamentary constitution.

To carry out the principle of armed intervention, the Congress of 1820 and 1821 authorized Austria to despatch an army to restore the old conditions. In March, 1821, the Neapolitans were defeated; their king was set back on his throne; and took a bloody and disgraceful revenge. At the same time the Austrians subdued a revolution in Piedmont. The Congress of Verona, in 1822, in spite of the protests of Great Britain, authorized the French government to invade Spain and relieve the corrupt and tyrannical Bourbon from the constitutional government to which he had sworn. Accordingly, in 1823, Spain, like her sister Naples, was invaded and the "legitimate sovereign" was reinstalled. A revolution in Portugal would have been dealt with in like manner, but for the declaration of the English that they would themselves defend that country if necessary. The principle of legitimacy now seemed triumphant. Four of the five Great Powers were holding together to put down revolutions which were protests against unbearable evils, and which nowhere aimed at establishing a republic or at deposing a sovereign.

Suddenly, another revolution broke out which could not so easily be set aside. In 1821 the Greeks rose against their legitimate imperial master, the Sultan of Turkey. Here the principle of the fatherhood of sovereigns and the brotherhood of subjects received a rude shock. The Greeks held the same religion as the Russians, and felt the same interest in the destruction of the Turkish Empire. Russia could not dream of aiding in the restoration of rightful authority over the Greeks. The question drifted on until 1827, when the English, French, and Russian fleets combined to destroy the Turkish fleet at Navarino, and with it, practically, were destroyed the remnants of the Holy Alliance. The Near Eastern Question - which is one of the main causes of the War of 1914 - helped to break up the unnatural union of the European powers in the Holy Alliance. Another cause of destruction was the refusal of England any longer to act with the Continental powers because they seemed inclined to intervene also in America. 


\section{PROPOSED EUROPEAN INTERVENTION IN AMERICA (1818-1822)}

Sooner or later the idea of protecting monarchy and legitimacy against the obstinate desire of portions of the human race to rule themselves, was certain to extend to America. A revolution was a revolution; the success of the Chileans and the Mexicans was a direct encouragement to the discontented Neapolitans and Spaniards and Portuguese. If the effort to substitute a liberal government for a despotic government was dangerous to the peace and virtue of Europe, the state of things in Latin America was alarming to mankind. To be sure, the first statement of the allied powers in the Treaty of November 20, 1815, left America out of account; but at the Congress of Aix-la-Chapelle in 1818 American conditions were freely discussed. Suggestions were made that one of the younger members of the Spanish ruling house be sent out as king of the colonies. Spain, on the advice of Alexander of Russia, asked the powers to help her to subdue the colonies. The United States at once awoke to her interests. May 13, 1818, President Monroe asked his Cabinet's opinion on coöperation with England.

"Whether the Ministers of the United States in Europe shall be instructed that the United States will not join in any project of interposition between Spain and the South Americans which should not be to promote the complete independence of those Provinces; and whether measures shall be taken to ascertain if this be the policy of the British Government, and, if so, to establish a concert with them for the support of this policy?"

Castlereagh, then Foreign Minister of Great Britain, favored "mediation." But, partly because of the objection of the United States, and partly because England refused to join in the use of force, the project was postponed for the time. It was revived by the recognition of the independence of several Latin-American states by the United States in 1822, which is described in the previous chapter; and was brought to a head by the invasion of Spain in behalf of the Holy Alliance in 1823 . At the Congress of Verona, King Ferdinand demanded aid from the Alliance against the Spanish-Americans. The next year a plan was evolved for a formal Congress on the American situation, to which the United States was to be invited. Euro- 
pean intervention meant French intervention; for that nation possessed a large army and navy and had already shown interest in the cause by the conquest of Spain.

A European congress on American affairs was upon the face of it dangerous to the United States. It introduced the principle that if $\mathrm{A}$ is at war with $\mathrm{B}, \mathrm{C}$ has a right to compel $\mathrm{B}$ to yield. The proposal was doomed from the beginning, by the holding back of England; and at this critical moment that attitude of England was greatly strengthened by the coming to the Foreign Office of George Canning. He was an experienced diplomat, a man of lofty views, and the first English statesman to realize the future power of the United States and the value to England of a good understanding. He was disposed to recognize the Latin-American republics, determined to break with the Holy Alliance, and, if necessary, was willing to oppose by force an invasion of America by third parties in the struggle. November 18, 1822, he wrote to his representative at the Congress of Verona, about England's interest in America :

"In the present state of the world, of the peninsula, of the country, the American questions are out of all proportion more important than the European, and if we do not seize and turn them to our advantage in time, we shall rue the loss of an opportunity never, never to be recovered."

\section{CONTROVERSY WITH RUSSIA (1821-1823)}

The European statesman who was most eager that an expedition be sent in aid of Spain was Alexander I of Russia, who had lost his former liberal spirit and was a determined supporter of absolute power in Spain and elsewhere. The United States felt a resentment against Russia, because of a ukase of 1821, which claimed the Pacific coast as far south as the 51st degree. The Russians included a warning not to approach within one hundred miles of the coast thus appropriated, and claimed exclusive rights in the north Pacific Ocean and Bering Sea. Adams was for some kind of resistance, but remarked, "I find proof enough to put down the Russian argument, but how shall I answer the Russian cannon?" In the course of his conference with Baron von Tuyll, the Russian Minister, Secretary Adams expressed a principle which later appears in the Monroe declaration. 
"I told him specially that we should contest the right of Russia No new to any territorial establishment on this continent, coloniza- and that we should assume distinctly the principle tion. that the American continents are no longer subjects for any new European colonial establishments."

In the despatch to Rush, July 22, 1823, Adams expressed the same principle more strongly:

"The application of colonial principles of exclusion, therefore, cannot be admitted by the United States as lawful upon any part

The United States on the Northwest Coast. of the northwest coast of America, or as belonging to any European nation. Their own settlements there, when organized as territorial governments, will be adapted to the freedom of their own institutions, and, as constituent parts of the Union, be subject to the principles and provisions of their constitution."

On the same day he instructed Middleton, American Minister to Russia, as follows:

"There can perhaps be no better time for saying, frankly and explicitly, to the Russian Government, that the future peace of No Russian . the world, and the interest of Russia herself, cannot be colonies in promoted by Russian settlements upon any part of America. the American Continent. With the exception of the British establishments north of the United States, the remainder of both the American continents must henceforth be left to the management of American hands. It cannot possibly be the purpose of Russia to form extensive colonial establishments in America. The new American Republics will be as impatient of a Russian neighbor as the United States; and the claim of Russia to territorial possession, extending to the 51st degree of north latitude, is equally incompatible with the British pretensions."

Rush, our Minister to London, December 17, 1823, communicated the same principle to Canning before the message on the Monroe Doctrine reached England:

No colonization on the Northwest Coast.

"In the course of my remarks I said that the United States no longer regarded any part of that coast as open to European colonization, but only to be used for purposes of traffic with the natives, and for used for purposes ", 
These discussions about Oregon and the principle of colonization involved a direct conflict of interests between Russia and the United States. Another issue, which seemed to the Administration artificial and roused the wrath of John Quincy Adams, was now brought into the whole controversy. October 16, 1823, Baron von Tuyll made a fateful announcement to Adams.

"Faithful to the political principles which she observed in concert with her Allies, she could in nowise receive any agent ... of any of the de facto governments which owe their existence to the events of which the New World has for some years been the theatre."

\section{European political principles against Americans.}

Adams rightly judges this to be a suggestion that the United States should stand aside in case of intervention, and caustically replied that the position of the United States -

"Had been made under the observance of a like neutrality by all the European Powers to the same contest. . . . if one No deparor more of the European powers should depart from their neutrality, that change of circumstances would necessarily become a subject of further deliberation in ture from neutrality toward America. this Government, the result of which it was not in my power to foretell."

Von Tuyll returned to the charge a few days later and Adams. asked him point blank what he meant by "political principles," to which the reply, was:

"He understood them as having reference to the right of supremacy of Spain over her Colonies."

November 17, 1823, von Tuyll read parts of a despatch (dated August 30), in which the Russian government spoke of -

"That power of union and agreement which in our times has created a new political system ... a new phase of European civilization . . . a policy whose object is simply to assure the peace of all the states which compose the civilized world."

Adams rightfully interpreted the despatches and the Russians' insistence to mean a sharp criticism of the republican system of the United States; and he prepared an answer defending the action of the Latin-American powers and the attitude of his 
own country. President Monroe thought this despatch too strong, and on his suggestion Adams postponed the discussion of the Russian "political principles," while stoutly defending the recognition of the Latin-American states.

\section{ATTITUDE OF ENGLAND (1818-1823)}

When the question of recognizing the new powers came to a head in 1818, the thought occurred to Monroe that Great Britain might perhaps act in common with the United States, and John Quincy Adams records, July 25, 1818, how Monroe proposed joint action:

“Two days ago he [Monroe] had very abruptly asked me to see Mr. Bagot and propose through him to the British Government an immediate coöperation between the United States and Great Britain to promote the independence of South America.... 'All South America, and Mexico, and the islands included.' I told him I thought Great Britain was not yet prepared for such a direct proposition."

Accordingly a proposal was made to the British government early in 1819, suggesting the recognition of Buenos Ayres and intimating that -

"If it should suit the views of Great Britain to adopt similar measures at the same time and in concert with us, it will be highly satisfactory to the President."

When Canning came into office in 1822, he took up the question of recognition from a new angle, appointed temporary consuls to the Latin-American states and, in March, 1823, made a public declaration that the time for recognition was approaching. This action was in part a protest against the invasion of Spain; in part it was due to the conviction of Canning that the Latin-American states were beyond the reach of any form of intervention; in part it was in harmony. with the British policy to hold the enlarged markets of the New World.

In 1823, Canning's plans came to a head. In four successive notes and conversations he urged Rush, American Minister at London, to join him in a declaration that would halt all schemes of the Holy Alliance. 
(1) On August 16 he asked Rush what-

"I thought my government would say to going hand in hand with this, in the same sentiment; not as he added that any concert in action under it, could become necessary between the two countries, but that the simple fact of our being known to hold the same sentiment would, he

Joint concert in sentiment. had no doubt, by its moral effect, put down the intention on the part of France, admitting that she should ever entertain it. This belief was founded, he said, upon the large share of the maritime power of the world which Great Britain and the United States shared between them, and the consequent influence which the knowledge that they held a common opinion upon a question on which such large maritime interests, present and future, hung, could not fail to produce upon the rest of the world."

(2) August 20, Canning sent Rush a formal statement of the point of his view toward the South American struggle: less.

“ 1 . We conceive the recovery of the Colonies by Spain to be hope-

" 2 . We conceive the question of the recognition of them, as Independent states, to be one of time and circumstances.

Recognition and no annexation.

"3. We are, however, by no means disposed to throw any impediment in the way of an arrangement between them and the mother country by amicable negotiation.

" 4 . We aim not at the possession of any portion of them ourselves.

“ 5 . We could not see any portion of them transferred to any other Power, with indifference."

(3) August 23, Canning notified Rush that the Allies were about to call a Congress on Spanish-American affairs. This drew from Rush a suggestion that the British government at once recognize the Latin-American states; in his own mind he was prepared on that. condition to take the responsibility of a joint declaration. The reasons which he stated are singularly like the doctrine which about the same time was being formulated in Washington.

“ My government would . . . regard as alike objectionable, any interference whatever in the affairs of Spanish America, unsolicited by the late Provinces themselves, and against their will ; ... it would regard the convening of a congress to deliberate upon their affairs as a measure uncalled-

No intervention by third parties. for, and indicative of a policy highly unfriendly to the tranquillity 
of the world ; . . . it could never look with insensibility upon such an exercise of European jurisdiction over communities now of right exempt from it, and entitled to regulate their own concerns unmolested from abroad."

(4) For several weeks Canning unaccountably cooled off, but on September 18, and 26, he renewed his pressure, insisting that the necessary steps were -

The United

States the

leading

power in

America.

"Full as much American as European, to say no more ... The United States ... were the first Power established on that continent, and now confessedly the leading Power. ... Could Europe expect this indifference?"

Since the two statesmen could not agree on the form of a declaration, Rush prudently reported to his home government and asked for instructions. We now know that Canning's apparent vacillation was connected with the attitude of France, and that he steered off when he became aware that the French government would take no part in an armed demonstration. This intention finally took the form (October 9) of a memorandum drawn up by the French ambassador, Prince de Polignac, to the following effect.

"That his Government believed it to be utterly hopeless to reduce Spanish America to the state of its former relations to Spain :

"That France disclaimed, on Her part, any intention or desire France will to avail Herself of the present State of the Colonot inter- nies, or of the present situation of France towards vene. Spain, to appropriate to Herself any part of the Spanish Possessions in America, or to obtain for Herself any exclusive advantages." 


\title{
Chapter IV
}

\section{FORMULATION OF THE MONROE DOCTRINE}

\author{
GROUND PREPARED FOR A DOCTRINE
}

A combination of forces brought the question of Latin America to a crisis toward the end of the year 1823. Till the separation of Mexico was accomplished, the downfall of the Spanish Empire was not certain ; but by this time it was clear that Spain had no longer the physical or moral forces necessary for rebuilding a structure which it could not keep in repair while in possession. Even had Spain possessed the old capacity for administration, the Revolution and the French invasion had reduced her almost to insignificance. Therefore the only hope of the Spaniards was the aid of the Holy Alliance.

The United States was coming into ever closer relations with Latin America, especially by the spread of commerce. Through the recognition of the independence of our neighbors, the administration had given hostages to fortune. For a reconquest of the colonies, whether by Spain or by the allies, would have been a refatation of the deliberate judgment of the Administration, Congress, and the people at large. By the settlement of the Missouri controversy in 1820 and 1821, room was left for a larger attention to foreign relations, and there was almost universal sympathy with the Latin-American governments.

This sympathy extended even to countries like Mexico and Brazil which officially chose the monarchical form, and even to the dictators who were flourishing in several countries. Then, as now, the American people were much affected by the forms of republican government; and did not feel resentful toward a despot, provided he nominally governed through a gang of his friends who called themselves a Congress. Sailors and business men who went into those countries must have seen for themselves that liberty was a scarce commodity. Still, 
much was excused to a people who had had so little opportunity to govern themselves, and who had passed through the miseries of so many civil wars. Public opinion in the United States seems to have confidently expected that, within a few decades at the utmost, the Latin-Americans would find ihemselves, and make good their imitation of American forms and principles of government.

In Europe the Holy Alliance was past the height of its power and had begun to go down hill. The Spanish invasion was the last notable act of that combination. It caused England to withdraw from the Alliance; and without England or against England, there could be no expedition across the Atlantic. The most determined supporter of intervention in America was Russia - or rather the Czar Alexander, who determined the Russian policy. The lecture on the "Political System" which Russia administered to the United States was apparently an effort to teach the United States her place. Instead, it served to call attention to the expansive spirit of Russia on the Pacific coast. Colonization had no very direct connection with the Latin-American problem, but it served as a text for the views of America on European expansion in America.

The clearest point in the whole confused situation was that the European powers looked upon the American continent as a legitimate field of enterprise for them. France and England were American powers, and neither of them had objections to annexing Cuba if it could be done conveniently. Russia was irritating to the United States, not because of Russian strength in America, but because, in all her immense territorial claims on the Pacific, there were only half a dozen little tradingposts and no permanent colonies.

Nevertheless it is to this day a wonder that the United States of America felt strong enough to protest, and to take the position of the one power in the world that had a right to lay down a permanent principle regulating the affairs of the western hemisphere. This boldness was due in part to the lively national spirit of Monroe and Adams, Clay and Calhoun, and their fellow statesmen; in part it was called out by a real danger that Europe might settle the affairs of the southern Americans and take the northern Americans later; in part the "Special Providence for little children and the United States", aroused Americans to impress on the world their conviction that what- 
ever the United States vigorously opposed must be given up. No success on those lines was then possible, without the enlightened policy of England under the guidance of George Canning. Of all the European powers England was the only one that had large interests in America. When England offered a kind of partnership to the United States, there was none to resist; when the United States declined the formal partnership, it still had the invaluable assurance of English sympathy and support. All this led to the message of December 2, 1823, in which the President published to the world his famous Monroe Doctrine.

\section{MONROE AND ADAMS}

One reason why the United States confronted this crisis with cheerfulness and confidence, was the character of the leading American statesmen. Henry Clay was more responsible than any other one man for the rapidity, not to say rashness, with which the United States had extended international brotherhood to the Latin-Americans. It was the same Henry Clay who had promised, at the beginning of the War of 1812, that the United States should "negotiate . . . a peace at Quebec or Halifax", and he showed the same optimism in 1823, the same belief in the star of his country, the same confidence in human nature. Clay, however, was quite outside the discussions which went on in the Cabinet from the first announcement by Rush that Canning proposed a joint declaration, down to the President's message of December 2.

The nominal leader of the country was President Monroe, a statesman and diplomat of very long experience. In fact, he had in 1796 been recalled by Washington in disgrace from France; and the treaty which he negotiated with England in 1806 had been ignored by President Jefferson. Monroe was a cautious man, very unwilling to give offense; at the same time he was a good administrator, who during the War of 1812 combined at one time the offices of Secretary of War and Secretary of State. Though by no means a first-class statesman, Monroe was acquainted with courts and camps, used to phrasing documents, and a profound believer in the future of his country.

Monroe's Cabinet contained three rivals - Calhoun, Crawford, and Adams. Calhoun far surpassed Crawford in weight and farsight. Adams was the most determined spirit, and as 
Secretary of State his was the official voice through which the President and Cabinet spoke; his was also the heaviest force; the declaration which issued from that Cabinet owed its form to him more than any other one man; and in his detailed Memoirs and his correspondence we have the most valuable body of material upon the origin of the Monroe Doctrine.

Two non-official councillors were brought into the discussion by letters written in October to the ex-presidents Jefferson and Madison. Of Jefferson Monroe asked :

" 1 st Shall we entangle ourselves, at all, in European politicks, $\&$ wars, on the side of any power, against others, presuming that

Advantages of Action with England.

a concert by agreement, of the kind proposed, may lead to that result? 2d If a case can exist, in which a sound maxim may, \& ought to be departed from, is not the present instance, precisely that case? 3d Has not the epoch arriv'd when G. Britain must take her stand, either on the side of the monarchs of Europe, or of the U. States $\&$ in consequence, either in favor of Despotism or of liberty . . .

"My own impression is that we ought to meet the proposal of the British gov't., \& to make it known, that we would view an interference on the part of the European powers, and especially an attack on the Colonies, by them, as an attack on ourselves, presuming that if they succeeded with them, they would extend it to us."

Madison replied, like Jefferson, approving in general the idea of a joint declaration with England, and accenting the position of the United States as the great source of free institutions.

"The professions we have made to these neighbours, our sympathies with their liberties and independence, the deep interest Against we have in the most friendly relations with them, Interven- and the consequences threatened by a command of tion.

their resources by the great powers, confederated against the rights and reforms of which we have given so conspicuous and persuasive an example, all unite in calling for our efforts to defeat the meditated crusade. . . .

"Will it not be honorable to our country, and possibly not alto-

Favoring

Spain and Greece. gether in vain, to invite the British Government to extend the 'avowed disapprobation' of the project against the Spanish colonies to the enterprise of France against Spain herself, and even to join in some declaratory act in behalf of the Greeks?" 
These suggestions showed that there was a double choice to be made. The first, between a joint declaration and a single American declaration; the second, between the rival views of leading statesmen as to whether the proposed declaration should be aimed at the specific danger to Latin America, or should be a general defense of American democracy, as opposed to European principles of government. The first of these questions was not a mere issue of form: it involved the whole issue of England's future place and influence in American affairs. The second question was a choice between the negative policy of standing against an innovation in European policies, and the active policy of coming out as a world-champion of democracy.

\section{CABINET DEBATE ON JOINT DECLARATION}

At the Cabinet meeting on November 7, began a momentous discussion of Canning's proposition. Rush favored a joint declaration, the President favored it, Jefferson and Madison favored it, Calhoun favored it; John Quincy Adams opposed. His was the only mind that seized upon the significant part of Canning's proposition.

"The object of Canning appears to have been to obtain some public pledge from the government of the United States, ostensibly against the forcible interference of the Holy Alliance between Spain and South America; but really or especially against the acquisition to the

Pledge against Annexation. United States themselves of any part of the Spanish-American possessions."

The caution was needed, for the United States had already occupied Spanish-American territory and was likely to demand more. It was only a few months since East Florida had been taken over by peaceful treaty with Spain. That treaty left Texas outside the boundaries of the United States; but already Stephen Austin and other Americans were looking toward that region and preparing to make settlements there.

Upon the point of a joint declaration, Adams won the victory. $\mathrm{He}$ brought into relief the rather puzzling fact that Great Britain was willing to make a joint protest against the interference of other European powers, but still held back from recognizing the independence of the Latin-Americans. Adams 
in conversation with the British representative added another argument which throughout the discussions had great weight in his mind.

"The United States, having acknowledged the independence of the trans-Atlantic territories, had a right to object to the interference of foreign powers in the affairs of those territories."

November 15, the Cabinet came over to this point of view when Adams phrased the same point in different words:

"I said I thought we should bring the whole answer to Mr. Canning's proposals to a test of right and wrong. Considering the South Americans as independent nations, they themselves, and no other nation, had the right to dispose of their condition."

\section{CABINET DEBATE ON POLITICAL SYSTEM}

At the very first Cabinet deliberation, November $\overline{7}$, Adams introduced another subject which was not touched upon in Canning's propositions :

"I remarked that the communications recently received from the Russian Minister, Baron Tuyl, afforded, as I thought, a very

Protest against the Holy Alliance.

to avow our principles explicitly to Russia and France, than to come in as a cock-boat in the wake of the British manof-war."

$\Gamma$ At that time nothing more was intended than a sharp answer to the Russian concessions to the "political system", which have been discussed in a previous chapter. Gradually the idea grew in Adams' mind that this manifestation of ill-will to the Latin-Americans and to republican government in general, might be fitly treated in the declaration which was pending. His feeling was aggravated by new communications from Russia expressing joy over the French invasion of Spain. Both Monroe and Calhoun objected to the vigor of Adams' draft of a reply; but the next day Monroe suggested that Adams inquire of the Russian minister: 
"Whether he intended by the term 'political principles' to refer to the governments established in the new states, as distinguishing them from those of Europe."

\section{Baron von Tuyll replied that:}

"He understood them as having reference to the right of Supremacy of Spain over her Colonies."

November 27, Adams submitted a paper called "Observations on the communications recently received from the Minister of Russia." Nowhere is there a better statement of the basis of the proposed declaration.

"From all the combinations of European Politics relative to the distribution of Power, or the Administration of Government the United States have studiously kept themselves aloof. They have not sought, by the propagation of their principles to disturb the Peace, or to intermeddle with

Doctrine of $]$ the Two

Spheres. the policy of any part of Europe. In the Independence of Nations, they have respected the organization of their Governments, however different from their own, and [Republican to the last drop of blood in their veins], they have thought it no sacrifice of their principles to cultivate with sincerity and assiduity Peace and Friendship even with the most absolute Monarchies and their Sovereigns."

Monroe accepted the clause, but objected to a ringing paragraph which was therefore omitted. It ran as follows:

"1. That the Institution of Government, to be lawful, must be pacific, that is founded upon the consent, and by the agreement of those who are governed; and 2 that each Nation ${ }^{\circ}$ is exclusively the judge of the Government best suited to itself, and that no other Nation, can justly interfere by force to impose a different Government upon it. The first of these principles may be designated, as the Proposed Liberty and Independence. principle of Liberty - the second as the principle of National Independence - They are both Principles of Peace and of Good Will to Men."

The despatch finally sent to Russia under date of November 27,1823 , may fairly be considered a portion of the Monroe Doctrine, for it grew out of the same circumstances as the larger declaration, in the President's message, and considerably influenced the paragraphs which appear there on the "European system." 


\section{CABINET DEBATE ON WARNING TO EUROPE}

Meantime, the Cabinet was still going over and over questions of the form which the American announcement should take. Monroe vacillated, and was anxious to give Rush power to act with Canning "In an emergency", which would have left the decision as to joint declaration in the hands of a distant minister. On this point also he gave way to Adams. The question then reverted to the stand that should be taken on the main issue of invasion of Latin America by third parties. Adams said, November 13, that news from Europe disturbed the President.

"I find him yet altogether unsettled in his own mind as to the answer to be given to Mr. Canning's proposals, and alarmed, far

Fear of Immediate Invasion of Latin America. beyond anything that I could have conceived possible, with the fear that the Holy Alliance are about to restore immediately all South America to Spain. Calhoun stimulates the panic, and the news that Cadiz has surrendered to the French has so affected the President that he appeared entirely to despair of the cause of South America."

The Cabinet argued and came to no definite point. In the archives of the Adams family at Quincy, Massachusetts, may be seen the original copy of a draft of a reply to Canning, made by Adams' own hand, and copiously annotated and altered by the hand of Monroe. One significant point throughout was that the United States would object to the Spanish American States making terms of peace by which they should grant to Spain special commercial advantages. Adams insisted on claiming the situation of "the most favored nation", and again his will prevailed. November 21 Monroe laid before the Cabinet a draft of his message, of which Adams says :

"Its introduction was in a tone of deep solemnity and of high alarm, intimating that this country is menaced by imminent and

Proposed

Protest against the Holy Alliance.

France. .. It also contained a broad acknowledgment of the Greeks as an independent nation ... and a recommendation to 
Congress to make an appropriation for sending a Minister to them.

“. . . I said the tone of the introduction I apprehended would take the nation by surprise and greatly alarm them. It would come upon them like a clap of thunder."

This is the turning-point of the whole discussion: Monroe, constitutionally timid, suddenly roused himself to the dangerous duty of setting Europe right; William Wirt, the Attorney-General, who had been absent till now, put the pertinent inquiry whether the United States was ready to fight in defense of this defiance by the President. Calhoun revealed a fear which lay at the bottom of all these discussions: he distrusted the Holy Alliance,

"The Holy Alliance had an ultimate eye to us; that they would, if not resisted, subdue South America. . . . Violent Ultimate parties would arise in this country, one for and one Danger. against them, and we should have to fight upon our own shores for our own institutions."

Again Adams was the one man in the Cabinet who seemed to understand the situation.

"I said if the Holy Alliance really intended to restore by force the Colonies of Spain to her dominion, it was questionable to me whether we had not, after all, been over-hasty in ac- An Ameriknowledging the South American independence. It can Cause. had pledged us now to take ground which we had not felt at all bound to take five years ago. . . . If they intend now to interpose by force, we shall have as much as we can do to prevent them, without going to bid them defiance in the heart of Europe. . . . earnest remonstrance against the interference of the European powers by force with South America, but to disclaim all interference on our part with Europe; to make an American cause, and adhere inflexibly to that."

The session of Congress was now approaching. In the last days of discussion, November 26 and 27, Adams set himself with all his might to take out criticisms of Europe and the European system, except so far as the state of things in Latin America was concerned. He urged -

“That we should separate it from all European concerns, disclaim all intention of interfering with these, and make the stand alto- 
gether for an American cause; and that at the same time the answer to be given to the Russian communications should be used Against the Holy Alliance. maintained by the United States with reference to as the means of answering also the proposals of $\mathrm{Mr}$. the designs of the Holy Alliance upon South America."

\section{AUTHORSHIP OF THE MONROE DOCTRINE}

The resultant of these various forces appears in two sections of the President's annual message of December 2, 1823. Reddaway, who is perhaps the best critic of the history of the Monroe Doctrine, satisfied himself that the document sprang substantially from the mind of John Quincy Adams, because it was in accord with principles which he had elsewhere maintained and defended. Later researches of Worthington Ford have brought to light the original drafts, in which it is easy to see how Adams' ideas gradually prevailed. He was radical in support of a declaration solely made by the United States; he was conservative in avoiding any discussion of monarchy or the home governments of European nations. He was aggressive in the desire to preach republicanism to the Czar, - which was almost the only point on which the President overruled him; he was original on the question of colonization. The principles of the message were dictated by John Quincy Adams ; and according to custom he prepared the short passage on the Northwest dispute and colonization.

On the other hand, Monroe tempered the phraseology of the message throughout, and undoubtedly drew with his own hand some of the most important passages. On December 4 he wrote to Jefferson and to his son-in-law Gouverneur :

"I have concurr'd thoroughly with the sentiments expressed in your late letter, as I am persuaded, you will find, by the message, as to the part we ought to act, toward the allied powers, in regard to So. America. I consider the cause of that country, as essentially our own. That the crisis is fully as menacing, as has been supposed, is confirmed, by recent communications."

"It has been done, nevertheless, in mild, respectful, \& friendly terms. Had I omitted to put the country on its guard, \& any thing had occurred of a serious character, I should probably have been censurd ; as it is they may look before them, and what may be deemed expedient." 
Congressman Plumer of New Hampshire in his diary minimized Monroe's part :

"I have strong reason to believe that this part of the message [that is, that relating to foreign affairs] bears the direct impress of Mr. Adams' genius. The ground assumed \& the doctrines inculcated are certainly his, \& if he did not write that part of the message (as the minister writes the King's speeches in England), I have little doubt that he submitted to the President in writing his views of what the message ought to contain so far as his Department was concerned \& that the President, in preparing his message, followed very closely not only the views, but the language of the Secretary."

It would be unfair to deny to Monroe the ability to rise to a great emergency, and the sagacity to accept suggestions from all sources and to come to a conclusion only after every phase of the subject had been presented to his mind. To sustain an eager and gifted Secretary of State who was convinced of the soundness of his own ideas on every point, showed Monroe to be a sensible and capable man, who deserves to have his name linked with a great document.

Another source which has in recent years been claimed for the doctrine is the Latin-American powers themselves. An ingenious Peruvian jurist has called it a "Pan-American declaration"; and another Peruvian, Arenas y Loayza, declared in 1905 that:

"the Monroe Doctrine is linked with our past and with our present, and gives us the key of the future of these Republics, considered in relation to the events of our times and the indications of the future."

In 1821, Manuel Torres, commissioned as the first minister from Colombia, urged the American government to make some such announcement:

"The present political state of New Spain requires the most earnest attention of the Government of the United States. There has occurred a project, long since formed, to establish a monarchy in Mexico, on purpose to favor the views of the Holy Alliance in the New World; this is a new reason which ought to determine the President of the United States no longer to delay a measure which will naturally establish an American Alliance, capable of counteracting the projects of the European Powers, and of protecting our republican institutions." 
Another claimant to the authorship of the Monroe Doctrine besides Monroe, Adams, and the Latin-Americans, is George Canning, who, in his famous speech of December 12, 1826, defended himself for not checking the intervention in Spain in 1823 :

"I looked another way -I sought material for compensation in another hemisphere. Contemplating Spain, such as our ancestors had known her, I resolved that if France had Spain, it should not be Spain ' with the Indies.' I called the New World into existence, to redress the balance of the Old."

This passage occurs not in a cool diplomatic dispatch, but in a parliamentary speech, where overstatement is no crime. It expresses the truth that the withdrawal of England from the Holy Alliance in 1822 took away the human possibility of any European invasion of America. Self-interest, commerce with the Latin-Americans, peaceful holding of her own colonies were the reasons for England's step. It is true, as Canning claims, that the attitude of Great Britain made it negatively possible for the Latin-Americans to remain independent. Positive aid was never given nor promised by Great Britain. So far from it, the declaration as announced by President Monroe was unwelcome to Canning; and it was not his intention to lay foundations for the claims and warnings which make up the so-called Monroe Doctrine in the Twentieth Century.

\section{TEXT OF THE ORIGINAL MONROE DOCTRINE}

The form of statement made by Monroe, after taking the counsel of his cabinet and a few other statesmen, appears in two separated passages of the annual message, the wording of which is as follows, in its precise sequence.

"At the proposal of the Russian Imperial Government, made through the minister of the Emperor residing here, a full power Northwest and instructions have been transmitted to the minister Claims. of the United States at St. Petersburg, to arrange, by amicable negotiation, the respective rights and interests of the two nations on the northwest coast of this continent. A similar proposal has been made by His Imperial Majesty to the Government of Great Britain, which has likewise been acceded to. The Government of the United States has been desirous, by this friendly proceeding, of manifesting the great value which they have in- 
variably attached to the friendship of the Emperor, and their solicitude to cultivate the best understanding with his Government.

"In the discussions to which this interest has given rise, and in the arrangements by which they may terminate, the occasion has been judged proper for asserting as a principle in which the rights and interests of the United States

Colonization. are involved, that the American continents, by the free and independent condition which they have assumed and maintain, are henceforth not to be considered as subjects for future colonization by any European powers. . . .

"It was stated at the commencement of the last session that a great effort was then making in Spain and Portugal to improve the condition of the people of those countries, and that it appeared to be conducted with extraordinary moderation. It need scarcely be remarked that the result has been, so far, very different from what was

Intervention in Spain and Portugal. then anticipated. Of events in that quarter of the globe with which we have so much intercourse, and from which we derive our origin, we have always been anxious and interested spectators. The citizens of the United States cherish sentiments the most friendly in favor of the liberty and happiness of their fellow-men on that side of the Atlantic. In the wars of the European powers in matters relating to themselves we have never taken any part, nor does it comport with our policy so to do. It is only when our rights are invaded or seriously menaced that we resent injuries or make preparation for our defense.

"With the movements in this hemisphere we are, of necessity, more immediately connected, and by causes which must be obvious to all enlightened and impartial observers. The Political political system of the allied powers is essentially System. different in this respect from that of America. This difference proceeds from that which exists in their respective Governments. And to the defense of our own, which has been achieved by the loss of so much blood and treasure, and matured by the wisdom of their most enlightened citizens, and under which we have enjoyed unexampled felicity, this whole nation is devoted.

"We owe it, therefore, to candor, and to the amicable relations existing between the United States and those powers, to declare that we should consider any attempt on their part to extend their system to any portion of this hemisphere as dangerous to our peace and safety. With the existing colonies or dependencies of any European power we have not interfered and shall not

Interposition in LatinAmerican States. interfere. But with the Governments who have declared their independence, and maintained it, and whose independence we 
have, on great consideration and on just principles, acknowledged, we could not view any interposition for the purpose of oppressing them, or controlling in any other manner their destiny, by any European power, in any other light than as the manifestation of an unfriendly disposition towards the United States.

"In the war between these new Governments and Spain we declared our neutrality at the time of their recognition, and to this

Neutrality

of the

United

States. we have adhered and shall continue to adhere, provided no change shall occur which, in the judgment of the competent authorities of this Government, shall make a corresponding change on the part of the United States indispensable to their security.

"The late events in Spain and Portugal show that Europe is still unsettled. Of this important fact no stronger proof can be Extent of Interposition. themselves, to have interposed, by force, in the adduced than that the allied powers should have thought it proper, on any principle satisfactory to internal concerns of Spain. To what extent such interposition may be carried, on the same principle, is a question in which all independent powers whose Governments differ from theirs are interested, even those-most remote, and surely none more so than the United States.

"Our policy in regard to Europe, which was adopted at an early stage of the wars which have so long agitated that quarter of the The Two globe, nevertheless remains the same, which is, not Spheres.

to interfere in the internal concerns of any of its powers; to consider the Government de facto as the legitimate Government for us; to cultivate friendly relations with it, and to preserve those relations by a frank, firm, and manly policy, meeting, in all instances, the just claims of every power; submitting to injuries from none.

"But in regard to these continents, circumstances are eminently and conspicuously different. It is impossible that the allied powers Extending the Political System. should extend their political system to any portion of either continent without endangering our peace and happiness; nor can any one believe that our Southern brethren, if left to themselves, would adopt it of their own accord. It is equally impossible, therefore, that we should behold such interposition, in any form, with indifference.

"If we look to the comparative strength and resources of Spain and those new Governments, and their distance from each other, NoSubjec- it must be obvious that she can never subdue them. tion by Spain. It is still the true policy of the United States to leave the parties to themselves, in the hope that other powers will pursue the same course." 


\section{Chapter V}

\section{INTERPRETATION OF THE ORIGINAL MONROE DOCTRINE}

1824-1826

\section{THE UNWRITTEN MONROE DOCTRINE}

THE text of Monroe's message of 1823 is not the only source from which the intent and construction of the Monroe Doctrine of that time can be drawn. The investigator must examine the official correspondence with the English Foreign Office and English minister in Washington, and the memoirs and letters of the principal participants in the doctrine, both in America and Europe. Account must be taken of the conditions of America at the time, and also of the attempts to give the Doctrine clearer form in the period which followed its first announcement. Fifty years ago it was the fashion to limit and pare down its meaning. Richard H. Dana much affected public opinion by his deprecatory note on the subject in his edition of Wheaton's International Law.

Much new material has recently come forward; and critical studies of the Monroe Doctrine show that we must grant to Monroe and Adams a wide vision, and may see in their declaration the germ of many of the more sweeping doctrines which have of late years been put forward by other American statesmen. These studies make it possible to state with more authority the principles as to the rights, privileges, and duties of the United States in the rest of America, as they were understood at the time. The framers of the original doctrine were not planning for the future so much as for their own time. In order to understand the later forms given to their principles, it is necessary to analyze the main features of the MonroeAdams Doctrine. 


\section{DOCTRINE OF THE TWO SPHERES}

The order of Monroe's statements is somewhat confused; and their relation to the conditions, which have been outlined in earlier chapters of this work, will be easier to understand if they are discussed under a rearrangement.

The first thing to settle was the ground of the doctrine. Monroe carefully restates the already familiar principle of the Two Spheres, as the proper relation of the Western and Eastern hemispheres. Up to the recent Spanish War this axiom was quoted by whomever wished to keep European countries at a distance. It is one of those comfortable and convenient generalizations which act perfectly until a change of circumstances comes about to disrupt them. The Doctrine of the Two Spheres had very little force so long as the greater part of both American continents was politically a part of Europe, so that their commerce, diplomacy, political policy, and official personnel, all came from over seas. Up to 1820 , whenever people talked of an "American sphere" and "American isolation", they meant no more than that the United States was free to take care of her own affairs in America.

The first difficulty in the Two Spheres theory is that several European powers retained colonies in America, which must make them interested parties in many American questions. For instance, the British colonies of Jamaica and Belize gave to that power a lively interest in all phases of the Isthmus question; the possession of Alaska led the Russians to claim the coast farther south; a footing in the West India Islands gave color to French conceptions of especial interest in Cuba.

Nevertheless, so long as the United States was practically outside of the questions which occupied Europe, it was easy to make a virtue of a withdrawal from the European concert, which is not possible to-day. The Monroe Doctrine was founded on the idea of a territorial division of the world into two politically separate hemispheres which roughly corresponded to a division in men's minds. The Old World was the realm of manufactures, the New World of food and raw materials; the Old World was subject to an actual division of military force, the New World was protected by distance; the Old World was at that time fast in the grip of military power, the New World was the scene of vast experiments in popular govern- 
ment; the Old World was crystallized, the New World was protoplasm. When once the idea was broken up that the various kinds of Americans were simply Europeans in another part of the world, the concept of a diversity of interests was natural. The Doctrine of the Two Spheres was effective because at that time it corresponded with the facts. The steady movement of immigrants and commerce across the ocean, the transmission of art and literature, the counter-movement of American political ideas, early began to obliterate that imaginary line drawn north and south through the Atlantic Ocean, which cut off America from Europe.

\section{DOCTRINE OF INTERVENTION}

Monroe's inclination to express his mind in public on the use of force by the Holy Alliance against Spain has already been noticed; and he could not quite deny himself the pleasure of making clear his moral objections. Between the lines it clearly appears that he considered it law and gospel for all the world, that every people has a right to its own chosen form of government. Hence he held it to be a denial of the fundamental principles of liberty for other states to compel a nation to receive a government which it detested. When it came to "intervention" or "interposition" in the New World, Monroe laid down three kindred propositions. (a) The Spanish colonies would never be reconquered by Spain alone. (b) For third powers to undertake to restore the colonies to Spain would be looked upon by the United States as unfriendly, or even hostile. (c) Though it is nowhere stated distinctly in the message, other documents show that the United States felt that recognition by the United States was a proof of independence; therefore a denial of the reality of independence was an imputation upon the government and people.

\section{DOOTRINE OF COLONIZATION}

The hardest-worked clause of the Monroe message from 1823 to 1915 has been that relating to colonization, which came into the controversy through the tactless combination by the Russian foreign office of a sweeping claim to territory, and a veiled criticism of American democracy. The underlying principle 
of Monroe's utterance was simply that, for the protection of the United States from difficulty and danger, the territorial status of America must be considered as already adjusted. The colonization clause of Monroe's message accords with Adams' instructions to Rush, our minister in England, four months earlier :

"A necessary consequence of this state of things [the destruction of the Spanish Empire] will be, that the American continents, henceforth, will no longer be subjects of colonization."

This meant that the boundaries of ${ }^{\top}$ America, so far as European powers were concerned, had already become crystallized; therefore any extension of the influence of those powers, either at the expense of organized communities, or by taking up territory claimed to be wild and unoccupied, was contrary to the spirit of the Monroe Doctrine. This sacredness of existing American boundaries was, however, still subject to two important reservations. (1) The United States did not undertake to protect any of its neighbors either against disintegration into smaller fragments, or against absorption by each other; and both those processes began immediately. (2) Still more important, the Monroe Doctrine was never a guarantee against ambitious designs of the United States itself ; and in the thirty years after Monroe's message, the boundary of the great republic was carried far to the northwest and southwest.

Monroe took pains to admit that the United States had no complaint to make of European colonies then existing. Later commentators have not always seen how much this limited the scope of the document. In our day, when Canadian newspapers advertise "American Bowling Alleys", - meaning thereby bowling alleys of a type common in the United States and unusual in British America, - we do not realize that in 1823 the United States was only the second American power in territory, and only the fourth in military and naval strength. Great Britain had a larger unquestioned area in America than the United States; and Great Britain, France, and Russia were all much more powerful military nations.

The framers of the Monroe Doctrine recognized this state of things; and, according to the testimony of John Quincy Adams, of Daniel Webster, and of other contemporaries, it was never the purpose of that Doctrine to shake the foundations 
of the European colonies still existing in America in 1823; especially in view of the fact that the people of the remaining colonies were quite satisfied to be dependent. The Doctrine was intended to make a distinction between such continuing colonies and the former Spanish and Portuguese colonies who had thrown off their allegiance, and in their own behalf and by the weight of their own arms had achieved actual, though precarious, independence.

The principle that the Monroe Doctrine was hostile to the creation of new European colonies out of remnants of the Latin-American empires was cordially conceded by the LatinAmerican states. In a letter of the Colombian minister, November 2, 1825, setting forth the objects of the Panama Congress, he included -

"The manner in which all colonization of European powers on the American continent shall be resisted, and their interference in the present contest between Spain and her former colonies prevented."

The Latin-American states were far from satisfied by Adams' statement to Congress that -

"Our views would extend no further than to a mutual pledge of the parties to the compact to maintain the principle in application to its own territory, and to permit no colonial lodgments or establishment of European jurisdiction upon its own soil."

The context and the circumstances show that Adams had expected to enter into a binding agreement for the defense of our neighbors against aggression; and that by the resistance of Congress he was compelled to take a less heroic attitude. The one public man who at that time seemed to expect the European colonies to fade away was Adams. Many years later, in 1848, Calhoun informed the Senate that the clause relating to colonization was not submitted to the Cabinet, and formed no part of the principle they intended to announce; it was the position taken by Mr. Adams. Adams said in conversation with the English minister in 1822 :

"It was impossible that the old exclusive and excluding Colonial system should much longer endure anywhere. . . . The whole system of modern colonization was an abuse of government, and it was time that it should come to an end." 
One point relative to colonization remains to be noticed: the Monroe Doctrine is silent on the question of the transfer of a colony from one European power to another, and such transferences had been frequent throughout the two centuries previous. To say nothing of the conquest of the Swedish, Dutch, and French possessions on the continent of North America, nearly every West India island had been at one time or another under the flag of some other power than that which it flew in 1823. The principle that territory must not be transferred from one European power to another was suggested in 1803 and again in 1810, - but in such cases it was some particular territory that we hoped to acquire. The revolt of the Spanish colonies, however, opened up a new field of diplomacy, for the first time made possible the combination of native American states, and put the holders of the remaining European dependencies upon the defensive.

\section{DOCTRINE OF POLITICAL SYSTEM}

Notwithstanding the long cabinet discussion over "the European political system", it is to this day doubtful whether Adams, who was responsible for the introduction of the phrase into the message, meant by it the Holy Alliance as a wrong kind of government or simply the disposition to use the power of Europe against the colonies. Monroe was conscious of a sense that republican institutions were on trial in this crisis. So far as the Monroe Doctrine was directed against monarchy at all, it lost point in the next four decades, during which much of Europe changed its conception of divine right. The later triumph of republican government in France and the weakening of autocracy in Russia made monarchy less conspicuous. The protest against the "political system of Europe" in Monroe's message was an appeal, not so much against one-man power, as against the mutual political insurance company which had been set up by the four great powers of continental Europe, and which threatened to take out a policy on the American colonies, in behalf of the Spanish monarchy.

Whatever the protest against European monarchy, there is no evidence at that time or since that the United States is prejudiced against American monarchy. Monroe hastened to recognize the short-lived Mexican Empire of Iturbide in 
Mexico; and the Empire of Brazil was usually on friendly terms with the United States from its inception in 1822 to its downfall in 1889. Nor has the United States hesitated to recognize such practical monarchies as the despotisms of Santa Anna and Diaz in Mexico, and Guzman Blanco and Castro in Venezuela. Indeed, Americans are accustomed to some forms of their own government which are very like Oriental despotisms. Surely, a people who complacently allow a boss to transfer his power to a son or kinsman, or to abdicate when weary of the sceptre, could urge no serious objection to a LatinAmerican monarch. In both cases the despot keeps the title to his office while he can "control the primaries", and thus prove the lawfulness of his rule.

\section{DOCTRINE OF PROTECTION OF THE UNITED STATES}

No greater mistake could be made than to look upon the Monroe Doctrine as due only to dangers to the Latin-American peoples. The message bristles with such phrases as "the rights and interests of the United States", "only when our rights are invaded or seriously menaced"; "the defence of our own [political system]"; "dangerous to our peace and safety"; "submitting to injuries from none"; "endangering our peace and happiness." The Monroe Doctrine can be understood only as a statement of a right of self-protection against action by foreign powers. The main purpose of the Doctrine was to prevent disturbances to our institutions, and to minimize dangers to the United States. Beyond this care for themselves, our grandfathers had a sincere and hearty desire and expectation that the Latin-Americans would soon build up a better government than Spain had ever given them. In supporting their claims, in recognizing their independence, in standing for their security from interference, Monroe and other generous spirits felt that they were keeping alive the flame of liberty.

The flame of liberty within the United States concerned the people of that country most, and they were the one large and successful republic in the world. Switzerland, San Marino, and Andorra, the only European republics which lasted through the storm of the French Revolution, were not significant. France seemed completely given over to monarchy. The new 
Latin-American states seemed the first fruits of the principles of our American Revolution, the beginnings of a world-realm of sister republics.

In 1823 there was still an apprehension that European nations might combine to diminish the power of the United States and to discredit its republicanism, a fear that had some grounds in view of the reaction that had taken place in Europe. Other statesmen followed Metternich in ascribing all the misfortunes of the period to the pernicious desire of men of low social condition to claim a share in governing themselves, and incidentally in governing their political betters. If the movements of 1820 in Naples and Spain, directed not so much toward republics as toward making monarchies decent, called for the intervention of the allied great powers, why should not the United States suppose that, as a republic, it was the object of hostility from Europe? The government of England was the only one which at that early period had glimmerings of the future advantages of a good understanding with the United States; and, partly for that reason, it was looked upon with suspicion by the rest of Europe.

\section{GEOGRAPHICAL EXTENT OF THE DOCTRINE}

What was the geographic area to which it was supposed by Monroe that his doctrine would apply? This question was was well answered in 1858 by Stephen A. Douglas, who thus explained the extent of the Monroe Doctrine.

"This declaration assumed the name of the Monroe Doctrine; and it has frequently been appealed to by American statesmen as a rule to be inflexibly adhered to, whenever any European power has threatened or attempted to extend its dominions upon the American continent - North, South, or Central America. This doctrine did not contemplate any interference on the part of the United States with the existing rights or colonial possessions of any European power, but was a protest against the extension of their power and policy in the future."

As for particular states, those powers were foremost in the thoughts of both Monroe and Adams which were already recognized, or soon to be recognized, by our government. These were, up to December, 1823, Buenos Ayres, Chile, Colombia, and Mexico; in the course of 1824, Guatemala and Brazil were added, and later about a dozen more. 
Another method of making up a map of the regions covered by the Monroe Doctrine is to notice what powers were included in the Panama Congress, invitations to which were sent out by Bolivar in behalf of the Colombian Republic in December, 1824. Acceptances were received from Mexico, Chile, Peru, Guatemala, and Brazil ; of the old Spanish provinces, Buenos Ayres alone held aloof. In the invitation to the United States appears a guarded reference to the only government which had achieved independence previous to the break-up of the Spanish Empire. This was the island of Santo Domingo, originally all Spanish, in 1697 divided with France, then in 1795 all transferred to France, but at once carried out from under French authority by a successful negro insurrection.

Buenos Ayres and Chile were the earliest countries to achieve complete independence, and Buenos Ayres was the first of the new countries to be recognized by the United States. There is not the slightest evidence that distance or commercial connection with Europe was thought to put those countries on a different footing from the states farther northward. With the exception of the three Guianas, and of Patagonia, which had never been settled or governed by the Spaniards, the ocean boundary line of the territory covered by the Monroe Doctrine followed the coast from Oregon around South America, and thence along the Gulf to the newly-established delimitation of the United States at the Sabine River.

Though Adams was restive at the continuance of European colonies in America, neither the colonization clause, nor the other parts of the message, contained any clause which applied to Canada. Then, and most of the time since, that region has been unquestioned by the United States as a permanent part of the British Empire. The right of Russia to some settlements on the northwest coast was. also unquestioned, though the southern extension was disputed. The relation of the Doctrine to the West Indies was more complicated and is still somewhat hazy.

\section{INFLUENCE OF TRADE}

One motive for Monroe's declaration was a desire to keep up the existing liberal trade regulations of Latin America. A recent writer on the subject, Roland G. Usher, in his Pan- 
Americanism defends the theory that the desire for West Indian trade was the controlling motive of Monroe and Adams. Since there is no proof of that theory in the sources, the author generously creates a body of supporting statements of which the following are fair samples: "This general slowness of communication [in colonial times] made literally impossible any active interference in America by European nations." "It created a separation in point of time between us and England which made anything approaching the government of the colonies from England a literal impossibility." - "We never were dependent upon England or any other European country." - "We had nothing which the Europeans would accept after importunity, and were obliged to sell our produce in the West India Islands, the Azores, or Africa." - "The supremacy of the sea has been for three centuries . . . in the hands of a nation [England] whose own position made inexpedient an attempt to expand its political authority outside its own borders." - "Access to the West Indies and to Europe we must have; only with England's consent and on England's terms could we have it." - "To secure freedom of access to the West Indian and South American trade we fought the Revolution." Usher seems to suppose that England forbade all trade between her West Indian islands and the United States. The wellknown facts are that the trade was prohibited only in American vessels, till 1822 was carried on largely and profitably by American importers in British ships. The United States was simply put by the British colonial system on the same footing in the British West Indies as the European nations. In 1822 Parliament passed an act admitting American vessels to some West Indian trade.

In the West Indies, there remained only two fragments of the once mighty Spanish American Empire,-Cuba and Porto Rico. The United States showed no disposition to consider the continuance of these colonies under the Spanish rule as out of accord with the spirit of the Monroe Doctrine. Nevertheless, the Cuban situation was acute in 1823, and undoubtedly that insecurity was a strong reason for Monroe's declaration. The question had already arisen whether the United States would be a party to any scheme for aiding Cuban independence. John Quincy Adams had expressed himself in a dispatch of April 28,1823, in which he said : 
"In looking forward to the probable course of events, for the short period of half a century, it is scarcely possible to resist the conviction that the annexation of Cuba to our federal republic will be indispensable to the continuance and the integrity of the Union itself."

\section{Adams further declared that -}

"The question both of our right and of our power to prevent it [the transfer of Cuba to Great Britain], if necessary by force, already obtruded itself upon our councils."

This dispatch, written before Monroe's message, throws a strong light upon the question whether the Monroe Doctrine included the transfer of American colonies from one European power to another. The truth is that the situation of Cuba was a powerful factor in the whole question, and the theory that the bounds of America were already fixed, so far as related to European possessions, was probably intended to cover Cuba as well as Oregon.

\section{GEOGRAPHICAL INTENT OF MONROE}

This review of the evidence as to the territorial meaning of the original Monroe Doctrine shows clearly that it covered all the continental independent States of the two Americas; that it was not directed against Russian America, British America, the various West Indian possessions, or the three European colonies on the north coast of South America; that Haiti was left out of account for the time, probably because it had proved such an impossible nut to crack that no European power coveted it. As for Cuba, the United States was content that it should remain Spanish till the pear was ready to drop into the hands of the waiting republic, which was not till 1898 .

On the geographical side, the Monroe Doctrine was intended to prevent in America exactly what has happened in Africa - during the last thirty years - the parceling out of a continent among European powers whose rival pretensions of interest cause friction which would not otherwise come into being. Perhaps a closer comparison would be to say that the Monroe Doctrine has protected America against the fate of Asia, - the taking over of weak civilized communities by stronger and more aggressive nations. The present attitude of Japan toward Asia is in effect very like that of the United States eighty years 
ago toward America. The Japanese wish to prevent the creation of centers of irritation in Asia, because the contests of European nations there would in future disturb the security of Japan. The comparison with Asia is made still clearer when we remember that three European powers - England, France, and Russia - were in 1823 also American powers, with all the rights necessary for the protection of their actual territorial holdings. It is impossible to resist the conviction that the main protection of America from the fate of Africa and Asia has been the world's sense that Latin America could be occupied only at the expense of the hostility of the United States.

\section{WAS THE MONROE DOCTRINE INTERNATIONAL LAW ?}

When Secretary Olney in 1895 declared that the Monroe Doctrine was "The accepted public law of this country ever since its promulgation", the effort was made to show that Monroe laid down a new principle of international law, which became binding on European nations. That was certainly not Monroe's point of view. He reasoned from the principles of the American Revolution that every nationality has a right to form such government as seems good to it; and so far forth he aimed to create respect for the national sovereignty of all true states. Though that principle is nowadays commonly regarded as a fundamental of international law and international relations, it was in 1823 antagonistic to the principles of public laws which the Holy Alliance represented.

Monroe also relied upon the theory that every nation has a right to take advance steps to prevent the creation of relations which will prove troublesome in the future. He supported the point by the Doctrine of Two Spheres. He made for the United States a definite claim for relief from the vexation of new and possibly hostile commonwealths growing up nearby as European colonies, on the promise that the United States would indefinitely keep out of the quarrels, complications, and adjustments of European powers. In that respect the American republic was assuming far less responsibility for weaker neighbors than the great European powers were then exercising over the small European States.

However logical this attitude of the United States, it was weakened by the effort to impose a novel principle by the sole 
weight of the federal republic; even the moral support of a joint declaration with England was declined. International law has often been created by the action of a strong power, afterwards confirmed by treaties and common consent; but it was a bold step for one of the second grade of nations, as measured by population and wealth, to lay down a law for all the active powers of Europe. Then, as now, it must not be forgotten that however great and populous the United States, her wishes, interests, and convictions cannot make her sole declaration into international law for other nations.

The paragraph on colonization simply appealed to the familiar principle that discovery and sporadic occupation could not give title to a wild country unless it were followed up by actual settlements. Whether Russia was "jumping the claim" of the United States was not a question of international law, but of fact; and a few months later Russia admitted that she did not expect to back up her territorial pretensions by actual settlement.

The "Political System" part of the declaration could certainly not be claimed to bind as international law, inasmuch as the public law of nations recognizes every type of government which actually exists in organized communities. A state like Russia, whose political system was thought to be odious by many Europeans, was nevertheless entitled to exist. On the general question whether the Monroe Doctrine was international law, it is significant that neither Monroe nor Adams used the phrase, "international law", with reference to the document; though they did refer to "public law" and to "intercontinental law", whatever that may be. By the term they apparently meant a kinship of institutions between all the American powers, and a common understanding that Europe must not interfere with the actual conditions of the New World. Upon that phrase, of indefinite meaning, Secretary Olney built his: "The accepted public law of this country ever since its promulgation."

\section{THE MONROE DOCTRINE AND PEACE}

To understand the Monroe Doctrine is impossible unless it is viewed as an attempt to keep peace in America. In the fortyeight years from 1775 to 1823 , war was going on continuously 
by land and sea in some part of the Western hemisphere, except from 1783 to 1791 . The United States was thrice engaged in war. Civil wars were going on somewhere in Latin America during every year after 1805 . A nominal war was still in progress in 1823 between those States and Spain. Monroe longed for peace - and he saw the way to peace in his hemisphere through shutting out the new kind of warfare of intervention that was threatened. He dreaded and had reason to dread a system of war by united Europe on disunited America.

The success of the Monroe Doctrine in this respect has been undeniable. Hostile European fleets have appeared in American waters, only half a dozen times since 1823. With the exceptions of the French in Mexico in 1861, and the Spaniards in Santo Domingo in 1862, none of these expeditions have been opposed by the United States Government. Yet who can doubt that what happened to those two weak countries would have happened elsewhere in America, but for the known objections from Washington?

Unfortunately, these peace principles did not restrain this country from itself making war upon Mexico in 1846, and on the American possessions of Spain in 1898. Nor has the Monroe Doctrine had any visible effect on the civil and international events in Latin America. The exclusion of foreign force has left America the freer to make war upon itself. The most serious indictment of the Monroe Doctrine is, that it has in some cases been invoked to prevent the establishment of order and international peace among our neighbors.

\section{LEADERSHIP OF THE UNITED STATES}

The underlying thought of Monroe's doctrine was that the United States was in a position of special interest toward our Latin-American neighbors, and therefore had a right to speak in a different tone from that of Europe. The special interest was strong. (1) As a republic, she felt a greater interest in and understanding of the neighboring republics. (2) Our nearness to several of the new American powers gave a special importance to commercial relations; for, from the beginning, great expectations were entertained of the profits of the South American trade.

(3) The idea of an isthmian canal was already in men's minds. (4) Beyond that, lay the argument that 
since the Latin-American states were independent, any nation that took steps against such independence was questioning our good judgment and truthfulness. For all these reasons, the United States asserted for herself a status in America which inany years afterwards was fitly phrased as one of "paramount interest."

The situation of one vigorous and modern state close to a group of weak communities which were not yet out of the social and military conditions of the eighteenth century, naturally suggested that the United States should assume the hegemony, should become the leader, guide, and interpreter of the rest of America. In intellectual development no such leadership has ever been achieved. Except for a hollow imitation of outward political forms, Latin America has never availed itself of the culture of its great Northern neighbor. In literature, educational methods, law, professional life, and social habits, a stronger influence has been exercised by Spain, France, and England.

As respects an international leadership, the Latin-American states were willing to accept it in 1823 and even asked for it; it was the United States that held back. For reasons which will be developed in later chapters, no such combination has ever been formed or can be formed. The friendly advances of the United States usually aroused suspicion. Forcible attempts to lead other States in an unwelcome path have increased that suspicion. John Quincy Adams was the only leader in his time who seemed to favor the hegemony of the United States over other American powers; and Adams was ignored in that respect by his own countrymen. Political leadership may possibly have been in the Monroe Doctrine, but Monroe was not aware of it; and in a hundred years of experience it has never proved to be a solution of the American troubles. 


\section{Chapter VI}

\section{TEST OF THE MONROE DOCTRINE $1824-1826$}

\section{EFFECT OF MONROE'S DECLARATION IN EUROPE (1823-1824)}

THE first visible effect of Monroe's measure was the sudden rise of Spanish-American securities in the stock market. English statesmen from the first showed a lively interest. Sir James Mackintosh hailed "this coincidence of the two great English commonwealths." Brougham declared that the message "dispersed ... joy, exultation, and gratitude over all the freemen in Europe." Canning, though annoyed that his offer of a joint declaration had been refused, felt his position in Europe greatly strengthened. So complete was the success of the message that, as has been noticed in a previous chapter, he publicly claimed the credit of it for himself.

The other European power most directly interested was Spain, and the government of that country offered a bad example of pride, stubbornness, and disregard of plain facts. The United States, through its ministers in Madrid, made every effort to persuade Spain to give over this hopeless ambition, and thus to keep as much as possible of the advantages of the friendship between the European-Spanish power and the AmericanSpanish powers.

The other continental powers were quick to see the meaning of the intervention and colonization clause, and Chateaubriand, French Minister for Foreign Affairs, said that Monroe's declaration -

"Ought to be resisted by all the Powers possessing either territorial, or commercial, interest in that Hemisphere."

Nevertheless, in spite of the objections of Czar Alexander, the French troops were withdrawn from Spain, which was a confession of defeat. The Parisian newspaper, $L^{\prime} E$ toile, declared : 
"Mr. Monroe is the temporary president of a republic situated on the eastern coast of North America. That republic is bounded on the south by the possessions of the king of Spain and on the north by the possessions of the king of England. The independence of this republic has been recognized for only forty years. On what title then are the Two Americas from Hudson's Bay to Cape Horn now under its immediate control?"

Von Gentz, the Austrian statesman, threw up his hands on the message :

"The separation of America from Europe has been completed irrevocably. If the reconquest of the colonies on the continent or their voluntary return to the old rule had not already become impossible, this opposition of the North American people, which has so long been developed and which has only now been openly declared would alone be sufficient to banish all thoughts of it."

Prince Metternich, the Atlas whose world was beginning to totter upon his shoulders, was reported by the British minister as saying of the pernicious effect of the message :

F" "That it was in exact conformity with the republican Principles, avowed and constantly acted upon by that Government ... This speech, he said, had confirmed him in an opinion he had before entertained, that great calamities would be brought upon Europe by the establishment of these vast republics in the New World, in addition to the power of the United States, of whose views no man could entertain a doubt after reading the Speech in question.... He held it, he said, to be impossible that any of the European powers could be of opinion (their commercial interests being secured) that the independence of America could be desirable, although circumstances might compel them to acquiesce in it."

These opinions are simply floating chips showing the direction of public sentiment among European statesmen. The most direct and practical result was in England. A side purpose of Monroe's declaration was to put pressure on Great Britain to take a very direct and positive step. This was the long-delayed acknowledgment of the political independence of the Latin-American countries, whose commercial independence was carefully nursed by the British government. The publication of the Monroe Doctrine convinced Canning that he must yield this point, though it meant breaking a friendship with 
Spain, and something like a defiance of France. December 31,1824 , he ordered the necessary steps to recognize Colombia and Buenos Ayres. As in his "redressing of balance" speech, he made a virtue of necessity by explaining that -

"The thing is done ... an act which will make a change in the face of the world almost as great as that of the discovery of the Continent now set free. The Yankees will shout in triumph, but it is they who lose most by our decision. The great danger of the time, a danger which the European system would have fostered, was a division of the world into European and American, Republican and Monarchical, a league of worn-out governments on the one hand, and of youthful and stirring States, with the United States on the other. We slip in between and plant ourselves in Mexico. The United States have got the start of us in vain; and we link once more America to Europe. Six months more, and the mischief would have been done."

When Spain protested and informed the British government that the colonies were "as infants in strength but old in crime, supported by ambition and defended by blood and anarchy," Canning retorted:

"Was a de facto government never to be entitled to recognition? Were time and circumstances never to produce any change? To have continued to call that a possession of Spain in which all Spanish occupation and power had been actually extinguished and effaced couk have rendered no practical service to the mothercountry, but it would have risked the peace of the world! . . Nothing more ridiculous in fact or more practically inconvenient for Spain herself could well be conceived."

\section{EFFECT OF MONROE'S DECLARATION UPON LATIN AMERICA}

News of the declaration of December, 1823, spread rapidly through the Latin-American countries. The researches of Robertson have brought to light interesting comments by newspapers and public men. Bolivar, for instance, was graciously pleased that -

"The United States of North America have solemnly declared that they will view as an act of hostility towards themselves whatever measures the powers of the European continent may take against Spanish America and in favor of Spain." 
Brazil was then looked upon by Portugal as a rebellious colony, and within two months offered to the United States an "offensive-defensive alliance with this Empire." When, in May, 1824, the first representative was received direct from Brazil, he spoke of "the concert of American powers to sustain the general system of American independence," - an uncomfortable phrase, to which Adams tells us "the President did not particularly allude in his answer." Within a few months, how"ever, various intimations reached Washington that LatinAmerican friends would like some distinct pledges of the method and degree of the military aid which the United States was anxious to give them.

\section{EFFECT OF MONROE'S DECLARATION ON THE UNITED STATES (1823-1824)}

Within the United States the doctrine was from the first popular. Seldom has a president's message produced such a speedy and complete effect. Webster said of it:

"One general glow of exultation, one universal feeling of the gratified love of liberty, one conscious and proud perception of the consideration which the country possessed, and of the respect and honor which belonged to it, pervaded all bosoms."

The Doctrine was bound to be popular because it not only paid a pleasing tribute to the enlightenment of Americans, but because it expressed a national sense of importance in the new western world. The eventual participation of America in the world's affairs was as inevitable as the flow of lava down the slope of a volcano. There has never been known to man an aggregation of political and social strength comparable with the United States, which did not make itself a factor in the world's history. Our diplomacy has sometimes been crude, uninformed, and disregardful of its own precedents; but it has expressed a national intention to speak in the councils of nations. The assurance of the physical power of the country, its ability to make itself felt, its sense of national interests, often in an exaggerated form, came from the natural eagerness of an energetic people, which had perhaps too much confidence in its own good judgment, and has always been more concerned 
about disorder in other lands than at home; but which felt itself what it really is - a living force in the affairs of mankind.

\section{COLONIZATION IN THE NORTHWEST (1823-1824)}

One of the main objects of the declaration was forthwith realized when a peaceful settlement was obtained with Russia. The United States was anxious to put a quietus on the Russian claims in the Northwest which included three elements: (1) A claim to the whole Pacific Coast north of the 51st parallel. (2) A claim to exclusive jurisdiction over the seas within one hundred miles of that coast. (3) A claim to the whole north Pacific Ocean and Bering Sea. For a time the United States attempted to negotiate jointly with Great Britain against these pretensions. It was soon clear that the two powers were rivals for the possession of the whole Oregon coast from the 55th to the $42 \mathrm{~d}$ parallels ; and they felt it expedient to make separate agreements with the third claimant. Our Treaty of 1824 with Russia acknowledged the parallel of $54^{\circ} 40^{\prime}$ to be the southern limit of Russia. The treaty further provided -

"That, in any part of the Great Ocean, commonly called the Pacific Ocean, or South Sea, the respective citizens or subjects of Rights over the high contracting Powers shall be neither disthe Open turbed nor restrained, either in navigation or in Sea. fishing, or in the power of resorting to the coasts, upon points which may not already have been occupied, for the purpose of trading with the natives, saving always the restrictions and conditions determined by the following articles."

In 1825 Great Britain and Russia also agreed upon $54^{\circ} 40^{\prime}$ as the southern boundary of the Russian claims. The farther boundary northward was clumsily described as a line "following the summit of the mountains, situated parallel to the coast," a boundary which never could be located. The net result was therefore a compromise, by which Russia admitted that Oregon was outside her sphere of influence; and the United States admitted that the Russians had a right to extend and colonize the area within which they had fixed and permanent posts. Russia retained all the territory necessary for her colonial development; and the United States scored in her pressure against the founding of new colonies in American territory. 
THE CLAY DOCTRINE (1824-1825)

Where was Henry Clay during these discussions which involved the welfare of those American communities in which he was so passionately interested? From March, 1821, to December, 1823, he was out of Congress and took no part in the discussions arising from Canning's proposition. He had hardly returned and been reëlected Speaker when, in January, 1824, he offered a joint resolution as follows :

"Resolved by the Senate and House of Representatives of the United States of America in Congress assembled, That the people of these States would not see, without serious inquietude, any forcible intervention by the Allied Powers of Europe in behalf of Spain, to reduce to

No European Intervention. their former subjection those parts of the continent of America which have proclaimed and established for themselves, respectively, independent Governments, and which have been solemnly recognised by the United States."

Though closely resembling Monroe's phrasing, this resolution would have in two ways committed the government far more deeply than the President's message : (1) It would have brought in the legislative department as a rightful sharer in such an announcement. (2) It would have been a pledge to take positive steps, if necessary, in defense of our neighbors. Somehow, this policy did not find favor, and it was handicapped by efforts to secure similar expressions of sympathy with the Greek cause. Therefore Clay, a few months later, practically withdrew his resolution, saying that he would "allow it to sleep where it now reposes - on the table." John Randolph could not lose the opportunity to tease the Speaker, and laid down as his dictum:

"It slept, - it took a dose of Turkey opium - a dose from the Levant, brought in a Greek ship."

Within a year Clay found himself in a place where he could have great influence on the future of America. John Quincy Adams, who liked eager and adventurous men, made Clay his Secretary of State. Without doubt the two men expected to place the United States at the head of a body of American states which should have a common understanding and a 
common policy of defense against European interference. Clay "owned that the object nearest his heart was the definitive pacification and settlement of the American states."

An early opportunity to enlarge the Monroe Doctrine occurred when Joel R. Poinsett was made first minister of the United States to Mexico. March 25, 1825, Clay instructed him as follows :

"Bring to the notice of the Mexican Government the message of the late President of the United States to their Congress, on No the 2d December, 1823, asserting certain important European Colonization. principles of inter-continental law, in the relations of Europe and America. The first principle asserted in that message is, that the American continents are not henceforth to be considered as subjects for future colonization by any European powers. In the maintenance of that principle all the independent Governments of America have an interest; but that of the United States has probably the least. . . . There is no disposition to disturb the colonial possessions, as they may now exist, of any of the European powers; but it is against the establishment of new European colonies upon this continent that the principle is directed. ... Europe would be indignant at any American attempt to plant a colony on any part of her shores, and her justice must perceive, in the rule contended for, only perfect reciprocity.

"The other principle asserted in the message is, that whilst we do not desire to interfere in Europe with the political system European of the allied powers, we should regard as dangerous Political to our peace and safety any attempt, on their part, System. to extend their system to any portion of this hemisphere. The political systems of the two continents are essentially different. Each has an exclusive right to judge for itself what is best suited to its own condition and most likely to promote its happiness; but neither has a right to enforce upon the other the establishment of its peculiar system. This principle was declared in the face of the world, at a moment when there was reason to apprehend that the allied powers were entertaining Favorable designs inimical to the freedom if not the indeEffect. pendence of the new Governments. There is ground for believing that the declaration of it had considerable effect in preventing the maturity, if not in producing the abandonment, of all such designs. Both principles were laid down, after much and anxious deliberation, on the part of the late administration. The President, who then formed a part of it, continues entirely 
to coincide in both. And you will urge upon the Government of Mexico the utility and expediency of asserting the same principles on all proper occasions."

Notwithstanding Clay's effort to treat this document as a condensed restatement of Monroe's message, the point of view is in several respects different. The phrase, "principles of inter-continental law", and the clever suggestion that Europe would feel toward American colonies in Europe just as the United States felt toward new European colonies, considerably strengthen the Doctrine of the Two Spheres. Clay's form of the colonization clause is decidedly weaker than Adams'. The whole doctrine is fortified by Clay's allusion to the abandonment of the European schemes of intervention, for it gave to the utterance of Monroe the prestige of success.

The first test of this somewhat enlarged doctrine was caused by renewed uneasiness about Cuba. Colombia and Mexico thought it undesirable that Spain should retain so large and rich a colony and took some steps toward a joint expedition to set Cuba free. Within the island there were some vague and resultless efforts in the same direction. A movement for annexation to the United States began and President Adams himself hoped and predicted that it would eventually come. Clay persuaded Mexico and Colombia to hold off. Then in the summer of 1825 a large French fleet made its appearance in the West Indies and rumors spread that Spain was about to transfer the island. This caused Clay, at Adams' direction, to notify France that the United States would not allow Cuba and Porto Rico to pass to any other power than Spain. The principle could be indirectly deduced from Monroe's declaration, inasmuch as such a transfer would be unwelcome to the Cubans and would bring an undesirable neighbor close to the United States. It is, however, the first distinct official statement that it is contrary to the interests of the United States for any European colony to be transferred to another European power.

\section{THE ADAMS DOCTRINE (1826)}

In 1826 it became clear that Clay's policy was thought too bold by many public men. Adams, in a message of March 15, restated the Doctrine as he saw it. Mexico and other powers 
had asked point-blank what means the United States intended to use for their protection, and that brought up the question whether Monroe had made a promise to protect them. This critical point had been deliberately left uncertain by Monroe; and when Adams faced it, he felt compelled to bring the protection of the United States within very narrow limits.

"The purpose of this Government is to concur in none which would import hostility to Europe or justly excite resentment in Each Party any of her States. Should it be deemed advisable to protect to contract any conventional engagement on this itself.

topic, our views would extend no further than to a mutual pledge of the parties to the compact to maintain the principle in application to its own territory, and to permit no colonial lodgments or establishment of European jurisdiction upon its own soil; and with respect to the obtrusive interference from abroad - if its future character may be inferred from that which has been and perhaps still is exercised in more than one of the new States - a joint declaration of its character and exposure of it to the world may be probably all that the occasion would require."

This exposition of the Doctrine became the official and accepted version. It was in effect that the United States had made a "pledge to herself" not to permit her neighbors to be subdued. Daniel Webster defended that construction and went further, to lay down a limpid statement of the main cause and justification of the various forms of the Doctrine as formulated by Monroe, Clay, and Adams :

"This declaration must be considered as founded on our rights, and to spring mainly from a regard to their preservation. It Foundation did not commit us, at all events, to take up arms of Rights of on any indication of hostile feeling by the powers the United of Europe toward South America. . . . A very States. different case would have arisen, if an army, equipped and maintained by these powers, had been landed on the shores of the Gulf of Mexico, and commenced the war in our immediate neighborhood. Such an event might justly be regarded as dangerous to ourselves, and, on that ground, might call for decided and immediate interference by us. The sentiments and the policy announced by the declaration, thus understood, were, therefore, in strict conformity to our duties and our interest." 


\section{DISCUSSIONS ON THE PANAMA CONGRESS (1826)}

Adams' message of 1826 was called out by the proposal of a Pan-American Congress to be held at Panama in 1826. This idea of a common meeting, at least of Latin-American powers, was . suggested long before Monroe's message. "A general assembly of the American States" was proposed in various Latin-American treaties in 1822. Agents of the United States in Buenos Ayres reported in 1823 that plans were afoot for a Congress of republics, both of North America and of South America. In December, 1824, General Bolivar issued a circular letter, asking the South American governments to send delegates to a Congress at Panama, which was to become a supreme authority. The Colombian and Mexican ministers sounded Clay, early in 1825, and in November tendered a written invitation to the United States to join in the discussion of -

"Those [matters] which, from their nature and importance, the late administration pointed out and characterized as being of general interest to the continent; for which reason, Joint Reone of the subjects which will occupy the attention sistance. of the Congress will be the resistance or opposition to the interference of any neutral nation in the question and war of independence between the new powers of the continent and Spain.

". . . As the powers of America are of accord as to resistance, it behooves them to discuss the means of giving to that resistance all possible force, that the evil may be met, if it cannot be avoided; and the only means of accomplishing this object is by a previous concert. ... The opposition to colonization in America by the European powers will be another of the questions which may be discussed."

Statements of the purposes of the Congress published in South America went very much farther and included a plan for setting Cuba free, and also -

"To form a solemn compact, or league, by which the states, whose representatives are present, will be bound to unite in prosecuting the war against their common enemy, Old Spain, Defensive or against any other power, which shall assist Spain League. in her hostile designs, or any otherwise assume the attitude of an enemy." 
Whether the North American or the South American version of the purposes of the Panama Congress was accepted, in any case the United States was plainly expected to agree to some positive policy of defending her neighbors; and both Adams and Clay were willing to bind the nation to that effect.

A prime difficulty was that the suggestion was artificial and out of relation to the conditions ; for no one any longer expected intervention of third parties from Europe, and the cause of Spain was hopelessly lost. Furthermore, the United States was by no means satisfied with its territorial possessions. The annexation of Florida was completed in 1821, and in 1825 and again in 1829, our government was trying to buy Texas from Mexico. At the same time the government was threatening Cuba, and was beginning to reach out for Oregon.

A second difficulty was that when strong opposition developed in Congress, Adams took back-water. In his annual message of December 6,1825, he talked of commercial reasons and took it for granted that the United States would join in the conference. When Congress held back, he sent to the House a special message of March 15, 1826, emphasizing commercial arguments which cannot be found in Monroe's version. In a special message to the Senate of December 26, 1825, he talked about commerce, maritime neutrality, religious liberty, and "the indirect influence which the United States may exercise." In his message of March 15, 1826, to the House, the President dwelt upon the altruistic side of the proposed Congress; on the need of agreements against ill treatment of Americans in Latin-American countries; on colonization; on Cuba and Porto Rico. He wanted the United States to accept the invitation because "it looks to the melioration of the conditions of man." On the question of a pledge to defend America against Europe the President hedged :

"With the exception of the existing European colonies, which it was in nowise intended to disturb, the two continents consisted Commerce of several sovereign and independent nations, whose and in- territories covered their whole surface. By this their dependence. independent condition the United States enjoyed the right of commercial intercourse with every part of their possessions. To attempt the establishment of a colony in those possessions would be to usurp to the exclusion of others a commercial intercourse which was the common possession of all. It 
could not be done without encroaching upon existing rights of the United States."

\section{FAILURE OF THE PANAMA CONGRESS}

Even on this mild and ingenious version of the purposes of the meeting, Congress could barely be brought to take the necessary action; and the Senate for some time declined to confirm the commissioners. In considerable part, this opposition was an attempt to discredit the Administration, but there was a genuine and widespread feeling against taking responsibility, which was voiced by the Senate committee.

"In the opinion of this committee there is no proposition, concerning which the people of the United States are now and ever have been more unanimous than that which denies not merely the expediency, but the right of intermeddling with the internal affairs of other States, and especially of seeking to alter any provision they may have thought proper to adopt as a fundamental law."

On motion of James Buchanan, later President of the United States, the House of Representatives, by 99 to 95 , adopted the following proposition, which, however, was never passed to a formal resolution:

"It is, therefore, the opinion of this House, that the Government of the United States ought not to be represented at the Congress of Panama, except in a diplomatic character, nor ought they to form any alliance, offensive or defensive, or negotiate respecting such alliance with all

No alliance or common] declaration. or any of the South American Republics; nor ought they to become parties with them, or either of them, to any joint declaration for the purpose of preventing the interference of any of the European Powers with their Independence or form of Government, or to any compact for the purpose of preventing colonization upon the Continent of America : but, that the People of the United States should be left free to act, in any crisis, in such a manner as their feelings of friendship towards these Republics, and as their own honor and policy may, at the time, dictate."

The Panama Congress had warm supporters of whom the ablest was Daniel Webster, then a member of the House. With great force and eloquence he defended not only the proposed 
meeting but also the Monroe declaration, of which he made a brief and valuable historical survey. He sets forth with especial clearness the relation of the whole question of neutrality.

"It has been affirmed, that this measure, and the sentiments expressed by the executive relative to its objects, are an acNeutrality knowledged departure from the neutral policy of the in America. United States. . . . Our neutral policy, therefore, not only justifies, but requires, our anxious attention to the political events which take place in the world, a skilful perception of their relation to our own concerns, and an early anticipation of their consequences, and firm and timely assertion of what we hold to be our own rights and our own interests. Our neutrality is not a predetermined abstinence, either from remonstrances, or from force. Our neutral policy is a policy that protects neutrality, that defends neutrality, that takes up arms, if need be, for neutrality."

\section{OUTCOME OF THE PANAMA CONGRESS (1826)}

The result of the whole discussion was a technical victory for the Administration. The Senate confirmed the commissioners, and the House made the necessary appropriation, but Clay's instructions to the commissioners show that the President had been compelled to modify his point of view. With regard to intervention the only direction was -

A joint declaration with no joint responsibility.
"To propose a joint declaration of several American States, each, however, acting for, and binding only itself, that, within the limits of their respective territories, no new European colony will hereafter be allowed to be established."

Another question which emerged for the first time in American diplomacy was that of a possible Isthmian Canal, upon which the Commissioners were instructed.

"If the work should ever be executed, so as to admit of the passage of sea vessels from ocean to ocean, the benefits of it ought not to be exclusively appropriated to any one nation, but should be extended to all parts of the globe, upon the payment of a just compensation, or reasonable tolls."

While this controversy was going on in Washington, the Panama Congress met and dissolved. Writers on the subject have almost ignored the fact that Great Britain was also 
invited to send representatives, and Canning commissioned one Dawkins whose functions were -

" To obtain the most regular and correct information of its proceedings, and to assure the American States collectively of the friendly sentiments and the lively interest in their welfare and tranquillity ' felt and expressed by the British Government."

He was also to oppose the conquest of Cuba, either by Spanish-Americans or Anglo-Saxon Americans. In a remarkable passage Canning warned the agent against the policy of leadership which Adams seems to have had in mind and to which Congress objected:

"To a league among the States, lately colonies of Spain, limited to objects growing out of their common relations to Spain, H. M. Govt would not object.

No headship of the United States.

"But any project for putting the U. S. of North America at the head of an American Confederacy, as against Europe, would be highly displeasing to your Govt. It would be felt as an ill return for the service which has been rendered to those States, and the dangers which have been averted from them, by the countenance and friendship, and publick declarations of Great Britain ; and it would too probably at no very distant period endanger the peace both of America and of Europe."

Without waiting for the American delegates, and without giving any official recognition to Mr. Dawkins, the Congress met at Panama in June, 1827. Only the four contiguous states of Peru, Colombia, Central America, and Mexico were represented. Chile, Buenos Ayres, Brazil, the Argentine and Paraguay chose to stay away. The delegates who appeared adopted a pact of "Union, Alliance, and perpetual Confederation", which never came to anything; then adjourned to Tacubaya in Mexico, and never assembled there. Of the two American commissioners one never left the States and the other died on the way. The next year a second Congress was called to meet in South America and nobody appeared except two representatives of the United States. The pact of union drawn up by the Panama Congress was ratified by only one power.

The result was a great mortification to Clay, but he would have been still more mortified if the delegates had attended, 
taken a leading part, and signed the proposed treaties; for their work would very likely have been overset by the Senate of the United States. The truth is that confidence in the LatinAmericans was declining. In 1828 Clay wrote to his friend Bolivar :

"I should be unworthy of the consideration with which your excellency honors me, . . . if I did not on this occasion state, that Ambitious designs of Latin-Amerambitious designs have been attributed by your icans. $\quad$ events in Colombia as proofs of these designs. enemies to your excellency, which have created in But ... I can not allow myself to believe, that your excellency will abandon the bright and glorious path which lies plainly before you."

\section{STATUS OF THE MONROE DOCTRINE IN 1826}

The original Monroe Doctrine was not a single docurnent or the work of one man, but a composite in which many statesmen aided, and public opinion took an active part. The process of making the doctrine began in 1822, when the Latin-American states were recognized; the United States thenceforward felt an obligation to prevent outsiders from disproving the righteousness of that recognition. The next step was the action of England in drawing out of the Holy Alliance and warning the United States of a plan of intervention. Without England European intervention was difficult; in the face of England's protest, it would be impossible.

The joint declaration proposed by England went over almost by accident, and that gave room for the powerful mind of Adams to work upon Monroe and his fellow members of the Cabinet in favor of a single declaration. Monroe's message, partly the work of the president, all of it infused with Adams' views, and doubtless modified in detail by other members of the Cabinet, was a strong, well-knit statement of the conditions, and also a skilful avoidance of any definite promise as to what the United States would do if the warning were disregarded. Europe accepted the doctrine, though trying hard to keep Cuba out from under its operation.

The Latin-American states liked the doctrine, which relieved them of their anxieties, and they asked for more medicine from 
the same bottle. They immediately began to press for a conference and a general American understanding. To their minds the results of such coöperation would be entirely favorable to them, and they did not ask at that time whether in return for protection the United States would expect a large influence in their affairs.

Adams as President ; and Clay, as Secretary of State, favored a distinct policy of leadership among the other American States, and were willing to take responsibilities in the way of military defense. It is impossible to say whether, if the country had stood behind them, they could have made any useful or permanent combination with our neighbors on that basis. They did not have the opportunity, because their political enemies, partly to do them harm, partly from a feeling of distrust of the wisdom of such active leadership in America, demanded positive statements as to their purposes. In those statements, when published, Adams and Clay considerably toned down the utterance of Monroe. They were obliged to disclaim any use of force, and even any serious diplomatic pressure, in defense of the former Spanish colonies. When that purpose was taken out there was little that any Pan-American Congress could do.

On the other side, Monroe's Doctrine was acceptable because it was the general belief, both in Europe and the two Americas, that he had prevented the despatch of armed expeditions from over seas. Furthermore, the colonization clause of the message was confirmed by the quick surrender of the Russians of their claims in the Northwest. In Cuba also the United States made clear its opposition to either independence or transfer to another European power, - a principle from which it never deviated until it made Cuba a dependency in 1898.

The general result was that the Monroe Doctrine in 1826 had done what was expected of it by Monroe. All attempts at enlargement failed, and it might have been laid upon the shelf, but for the unquenchable fact that so long as the LatinAmerican powers were unable to defend themselves, there would always be danger of European nations assailing them. The immediate danger was over; but the conditions out of which that danger came, continued; and therefore, there was still need for a general principle as to American affairs which could be employed, whenever like dangers came again. 



\title{
PART II
}

\section{VARIATIONS OF THE MONROE DOCTRINE 1827-1869}

\author{
Chapter VII
}

\section{DEVELOPMENT OF LATIN-AMERICAN NATIONS 1827-1844}

\section{LINES OF LATIN-AMERICAN DEVELOPMENT (1827-1844)}

For about twenty years after the Panama Congress the Monroe Doctrine was hardly mentioned, and its principles were invoked only so far as they applied to the future of Cuba. The people of the United States during this period were hard at work filling up their own area, and public attention was engaged by sharp political and party strifes. Meantime, the business men were developing a splendid commercial marine to other parts of the globe, and laid less stress than formerly on the commerce of Latin America, which developed slowly. The only point of friction with a Latin-American state was the Mexican province of Texas, where Americans settled, built up a community, and in 1836 declared themselves independent. Interest in California was confined to a few traders and explorers, and the country showed apathy even on the question of Oregon.

The Latin-American states, so far as they developed, occupied all the mainland from the United States southward. The Spanish Empire had been split into fragments and most of the larger groups were again subdivided. Most of the old viceroyalty of Buenos Ayres held together except that the little State of Uruguay in 1825 set up for itself, and the old province of Upper Peru became the independent state of Bolivia 
in 1825. The original Colombia in 1831 split up into New Granada (to-day called Colombia), Venezuela, and Ecuador. The five small States of Honduras, Guatemala, Nicaragua, Salvador, and Costa Rica in 1823 formed themselves into a Central American Confederation, but in 1839 broke up into five primordial elements. Except that Santo Domingo and Haiti united in 1822 and separated again in 1844, no changes occurred during this period in the political status of the West Indies.

Each of these new states, as it came into being, claimed the right to enter the family of nations as a full and equal political community. Eventually all those that were permanent were received on nominally equal terms by European countries. Ministers and consuls were exchanged, and treaties were negotiated with them on a variety of subjects. They dreamed of becoming rich and powerful nations on the same scale as the European powers. They felt that they shared in the destinies of civilized mankind. This development of weak states in America resembled the appearance of so-called independent states out of the side of Turkey: Greece, Servia, and Rumania at just this time were assuming governments of their own.

\section{CONFUSION AND ANARCHY (1827-1844)}

Thus left to themselves, both by the United States and Europe, the new republics had a clear opportunity to build up stable communities. Monroe never expected the LatinAmericans to go through a century of weakness ; he did not look forward to a permanent need of protection; he did not foresee how much they would suffer from internal and civil wars ; he did not guess how long Spain would insist on an empire that had vanished. Nominal hostilities with Spain continued until that country reluctantly recognized the independence of its former colonies in 1836. As late as 1847, General Flores, a defeated dictator of Ecuador, went over to Spain, and tried to raise troops there for the subjugation of his own country.

From time to time a large-minded statesman arose in Latin America and made an effort to bring his countrymen, or at least part of them, together into a permanent union. The most hopeful of these efforts resulted in a Latin-American Congress which met at Lima in 1847, to concert measures 
against Spain. Representatives of five of the states of the west coast of South America attended and drew up a plan of union. Arbitration was to be invoked if quarrelling states could not otherwise agree. Any state which refused to abide by arbitration was to be boycotted by all the others. This Union speedily broke down, or rather, never was organized at all. Instead of building up a common national spirit, the states large and small fell into local wars, in one of which Brazil laid a paper blockade on the coast of Buenos Ayres, against which the United States roundly protested.

Still more destructive of order and confidence were the civil wars and rapidly changing governments. In Mexico, between 1821 and 1848, there were six or seven different governments, mostly founded on military usurpations. Every Latin-American country, except Brazil, Buenos Ayres, and Chile, fell into the hands of changing dictators, some of whom moved from country to country, - plotting, revolting, murdering, and in their turn disposed of by plot, revolution, and murder. Such governments were certain to abuse the persons and property of their own subjects and also of foreigners.

Few of them put their energies into building roads, improving ports, and stimulating the production of their country. "The Argentine Nation," as Buenos Ayres came to be called, showed the greatest prosperity and the strongest sense of the money value of an orderly government, among all the LatinAmerican states.

These weak and despotic governments reacted against the foreigners who came as diplomats, business men, and travellers. Not one of the Latin-American states was able to afford to foreign residents the degree of protection to life and property which was secured in Europe and the United States. Hence, much diplomatic energy went into attempts to adjust claims against the Latin-American powers by injured foreigners and particularly by citizens of the United States. These claims began far back in the early stages of the South American Revolution, when it was hard to tell who was a belligerent, who was neutral, and who controlled a legitimate government. Vessels were captured right and left; temporary governments bought supplies and borrowed money and their successors refused to be responsible. Cargoes were seized on slight pretexts by custom-house officers; arrests were made by igno- 
rant and unfriendly officials. The original presumption was that the Latin-American states were European in origin, traditions, law, government, justice, and relations with other countries; but these expectations received many jolts. They looked toward Europe for their luxuries and their books but there was little intercourse or understanding between them and the United States. After 1840 the efforts to secure good government became almost hopeless in most of these states. Strong and patriotic men came into public life and occasionally to the highest offices; but dictators multiplied, commerce was impeded, and wars impoverished many parts of the Americas. The world came to expect misrule, and indifference to national obligations.

\section{TRADE AND BOUNDARIES (1827-1844).}

The United States suffered as much as European powers from these disturbances, but still retained an unaccountable belief in the sister republics. One evidence was the speedy recognition of new states as they came along, and also of the chameleon governments in the older states. It became necessary for the United States to adopt a policy as to the recognition of one government after another in the same country, and American representatives were instructed as to de-facto governments :

"Your business is solely with the actual Government of the country where you are to reside, and you should sedulously endeavor, by a frank and courteous deportment, to conciliate its esteem and secure its confidence. So far as we are concerned, that which is the Government de facto is equally so de jure."

For the trade relations which were such important factors in the development of the Monroe Doctrine, treaties were necessary; and a long line of commercial agreements began with the Colombian treaty of 1824 . The United States was keen to secure from the Latin-Americans articles against any grants of especially favorable terms of commerce to their former home country.

Coupled with the commercial treaties were a boundary treaty with Mexico in 1828, and various treaties for the settlement of claims with Mexico and ather countries. The pressure on 
Mexico, which was the worst offender, combined wir movement on Texas, early brought that country into a stait discontent and personal hostility toward the United States but nearly every other power in the two Americas engaged in irritating disputes. The original idea that the Latin-Americans were a brave, capable, but backward people who needed only a little time to establish firm governments, was constantly undermined by these difficulties.

\section{FALKLAND ISLANDS (1831-1832)}

In only one instance in this period was there a dispute which involved the question of intervention by European powers. The Malvinas, or Falkland Islands, lying east of Patagonia, were used by some American fishermen as a port of refuge and supply, In 1829 Buenos Ayres declared that the Islands were part of that republic and sent out authorities to talsepossession. In 1831 they seized three American sealing schooners; and Captain Duncan in the United States ship Lexington sailed in and made himself master of the islands, arresting some of the resident Argentines. The minister of the United States at Buenos Ayres denied any right to interfere with our fishermen. Meanwhile Great Britain sent out a ship, the Clio, and occupied the islands on the ground that they had been an English possession for more than sixty years.

As against Buenos Ayres, the United States continued to deny the authority that was asserted, and declared that the so-called colony was -

"An establishment dangerous to our commerce, which it is necessary in self-defenee that we should break up, whether the Government of Buenos Ayres have a title to the jurisdietion of the istands, or have not. If they have the jurisdiction, they have no right so to use it as in Jurisdiction over Fisheries. any-way to interfere with our right of fishery, established by long usage; but above all to use it in the irregular manner stated in the affidavits."

Buenos Ayres insisted that the action of England was a breach of the Monroe Doctrine. The United States, however, acknowl edged the British sovereignty, and years afterward Secretary Bayard wrote upon this question: 
rant he resumption of actual occupation of the Falkland Islands thrreat Britain in 1833 took place under a claim of title which t. been previously asserted and maintained by that Governsent, it is not seen that the Monroe doctrine, which has been invoked on the part of the Argentine Republic, has any application to the case."

The same indifference in Washington to an actual show of European force on American coasts was known when, in 1845, France and Great Britain united to blockade the coast of Buenos Ayres.

\section{PROTECTION OF CUBA (1827-1844)}

Evidently the State Department was little concerned about the influence of the United States over other American states toward the South. It went through the routine of appointing and despatching ministers, man of whom could not speak Spanish and had little personal interest in their work. Consuls-were always falling into quarrels over unfriendly laws and interference with American vessels and merchants. Almost the only opportunity for apping territorial principles of the Monree-Doctrine was with reference to Cuba, for nobody was trying to "colonize" any part of America, except so far as the British claims to Oregon were covered by Monroe's phrase.

Cuba was prosperous and wealthy during the commotions in Latin America. After 1825 the Spaniards began to draw the lines more closely on its foreign trade, of which the greater part was with the United States, and loaded it with heavy duties. The Cuban government made a feeble effort to turn the tables on its former colonies by invading Mexico. A small party of Cubans favored independence; and to weaken their demands, the Cubans for a short time received the right to send deputies to the Spanish Cortes.

At various times the cry of danger of absorption by Great Britain or France was raised, and American statesmen laid down as a fundamental doctrine that Cuba must not pass to any other European power. Everett, Minister of the United States to London, gave such a warning in 1827. Van Buren, as Secretary of State, in 1829, restated this principle and added 
a brief discussion on the importance of preventing Cuba from setting the slaves free:

"The Government . . . has always looked with the deepest interest upon the fate of those islands, but particulas'y of Cuba. Its geographical position, which places it almost in sight of bur southern shores, and, as it were, gives it the com-. Cuba. mand of the Gulf of Mexico and the West Indian seas; its safe and capacious harbors ; its rich productions, the exchange of which, for our surplus agricultural products and manufactures, constitutes one of the most extensive and valuable branches of our foreign trade, render it of the utmost importance to the United States that no change should take place in its condition which might injuriously affect our political and commercial standing in that quarter. Other considerations, connected with a certain class of our population, make it the interest of the southern section of the Union that no attempt should be made in that island to throw off the yoke of Spanish dependence, the

Slavery. first effect of which would be the sudden emancipation of a numerous slave population, whose result could not but be very sensibly felt upon the adjacent shores of the United States."

When he became President, Van Buren followed out the same policy. Minister Stevenson, June 16, 1837, expressly reiterated the principle of no transfer of Cuba and Porto Rico:

"That the United States could not see with indifference Porto Rico and Cuba pass from Spain into the possession of any other Powers."

In 1840 it was rumored that Great Britain was about to annex Cuba as security for Spanish loans held by British subjects; and Forsyth, July 15, 1840, made an explicit and thoroughgoing statement:

"Should you have reason to suspect any design on the part of Spain to transfer voluntarily her title to the island, whether of ownership or possession, and whether permanent or No transfer temporary, to Great Britain, or any other power, you of Cuba. will distinctly state that the United States will prevent it, at all hazards, as they will any foreign military occupation for any pretext whatsoever; and you are authorized to assure the Spanish Government that in case of any attempt, from whatever quarter, to wrest from her this portion of her territory, she may securely depend upon the military and naval resources of the United States to aid her in preserving or recovering it." 
Under Tyler's adm inistration, the fear of English interference was again $\mathrm{fe}_{\mathrm{\prime}} \mathrm{it}$, and Daniel Webster went farther than his predecessors. In 1843 he wrote to the consul at Havana:

“The Spanis sh government has long been in possession of the

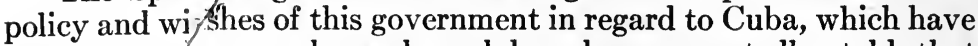
Defence of never changed, and has been repeatedly told that Cuba. the United States never would permit the occupation of that is sland by British agents or forces upon any pretext whatever; ; and that in the event of any attempt to wrest it from her, she migkit securely rely upon the whole naval and military resources of this country, to aid her in preserving or recovering it."

Notwithstanding these scares, there is little reason to suppose that England would at that time have cared for the Cuban colony of slave plantations, even though the United States had been indifferent. The real danger to Cuba was from the United States, in which a desire for annexation had long been active and was not in the least restrained by the limitations laid down in the Monroe Doctrine.

\section{ANTI-MONROE ASPIRATIONS FOR TERRITORY}

The nervousness lest Cuba should be snapped up by some foreign power was not matched by virtuous resolves to keep hands off from American territory. During this whole period the United States was looking with desire on the three Mexican provinces of Texas, New Mexice, and Galifornia. Jackson foltowed up Clay's eartier suggestion for a purchase of Texas by proposing in 1829 to buy that province; but Mexico steadfastly refused. After Texas formally declared independence in 1836, annexation to the Federal Republic was certain to come. The general belief that the United States would eventually seize Mexican territory was reflected by the action of Commodore Jones when, in 1842, he seized and held for a few hours the town of Monterey, which was the capital of California. About the same time, the far-off Sandwich Islands (now known as the Hawaiian Islands) offered to annex themselves to this country, and thereby to give the United States a footing in the Pacific Ocean. The contemporary movement upon Oregon gave strength to the interests in the Pacific Coast. In 1845, President Polk, through Slidell, attempted to buy New Mexico and California. 
All these territorial suggestions and aspirations showed that in the minds of American statesmen and American people there was nothing sacred in Latin-Ameriean territory, and no objection to the establishment of what would virtually be colonies within the boundaries of Latin-American states. The of pretection to other powers was losing ground; the idea of national interest and of a presumptive right of people of a superior civilization to occupy and possess the territory of inferiors was coming forward as an aeknowledged motive. The chivalry of Monroe's declaration was forgotten; the desire to expand the boundaries and power of the United States seemed to legalize the várious possibilities of coloniat expansion.

\section{THE MONROE DOCTRINE AND SLAVERY (1836-1844)}

During this period of quiescence of the Monroe Doctrine one question aroused new conviction that the United States must take responsibility for her neighbors, and might even justify spoliations upon them, if it could be guessed that European powers were disposed to interfere. The slave power was rising, had great influence in the national government, and was alert to find new slave-holding territory; and it made every effort to prevent abolition in the neighboring foreign countries which maintained slavery. The nearest of such countries was the Republic of Texas, which in 1844 entered into a negotiation with the United States for admission as a State of the Union. The desire of the Texans was natural ; they were actually free from Mexican control, were maintaining an independent government, and were American by birth and traditions. On the side of the United States, John C. Calhoun was made Secretary of State by Tyler in order to bring about the annexation of Texas.

The British minister, under instructions from London, urged the Texans to remain independent and to abolish slavery; and even hinted that the British government would pay for the slaves thus set free. Calhoun, therefore, protested to the British government (April 18, 1844).

"So long as Great Britain confined her policy to the abolition of slavery in her own possessions and colonies, no other country has a right to complain. . . . But when she goes beyond, and avows it as her settled

Urging abolition in America. 
policy, and the object of her constant exertions, to abolish it throughout the world, she makes it the duty of all other countries, whose safety or prosperity may be endangered by her policy, to adopt such measures as they may deem necessary for their protection."

This principle is, in brief, that no foreign power has a right to advise a Latin-American state to do anything which is disagreeable or unwelcome to the United States. All the independent Latin-American states except Brazil early abolished chattel slavery, and the United States was not acting on their behalf. On the contrary, Calhoun made no attempt to connect it with any general doctrine relating to Latin-American countries, for he fully accepted Texas as an Anglo-Saxon country. Nevertheless his despatch is at the bottom an assertion of a right of the United States to compel European nations to refrain from doing certain things in America which were justified under ordinary international law, did not interfere with the rights or interests of other American powers, and did not question the sovereignty of the United States.

\section{REAWAKENING OF THE MONROE DOCTRINE (1844)}

"The virtue of the Monroe Doctrine," says Captain Mahan, "without which it would die deservedly, is that through its correspondence with national necessities, it possesses the inherent principle of life, which adapts itself with the flexibility of a growing plant, to the successive conditions it encounters." These changes of conditions about 1844 brought up a series of significant questions affecting all America. The first was the rival claims to Oregon, which, since 1818, had been occupied under a treaty for joint occupation with Great Britain. The second was the future of Cuba. The third was the question of an Isthmian Canal, which later became the most difficult and disturbing influence in the course of American diplomacy. A fourth was the intolerable vexation of the injuries to the lives and property of foreigners in Latin-America and the consequent claims.

The only way to stop this confusion and loss was to stop the wars, and the United States during the twenty years following Monroe's declaration never felt the responsibility of a peacemaker. Little had been done or suggested to settle or prevent 
the internal quarrels of the Latin-Americans. No administration from Jackson to Polk showed an understanding of these people, or a purpose to aid the few men of character and public spirit among them who came to the front. Jackson was at one time ready to make war on Mexico on the basis of our claims. Some efforts were made by treaty and commissioners to adjust the difficulties with Mexico; but not to rescue that or any other state from anarchy. 


\section{Chapter VIII}

\section{THE UNITED STATES OUT OF HER SPHERE}

1845-1853

\section{A CHANGE OF PRINCIPLES (1845)}

The inauguration of James K. Polk, March 4, 1845, marks a great change in public sentiment toward Latin America. The extent of his designs on other people's territory was not then known, but he had been elected as the champion of the annexation of Texas. A few hours earlier Congress had passed a joint resolution for the annexation of Texas, despite the protests and threats of Mexico. Instead of the peaceful doctrine that America ought to remain as it was, the United States now began systematically to rearrange the map of North America at the expense of her neighbors and to maintain with all her might that there was a mysterious thing calted the-Monroe Doctrine which prevented any one from interfering with the Latin-Americans, = except ourselves. From this time to 1861 every President and almost every Secretary of State laid down sweeping principles in accordance with whatever he thought allowable treatment of other powers. Yet almost all of them from time to time appealed back to Monroe, just as people who know everything turn to the encyclopedia to confirm their infallibility. The bottom principle of these various forms of what might be called "Monrovoid Doctrines" was the right to despoil our neighbors.

Polk pushed to completion the annexation of Texas: he had a right to feel that the protests of Mexico had no foundation: there was nothing in the moral code, international law, or the Monroe Doctrine to prevent an actually independent nation from giving its voluntary consent to become a part of the United States. Polk, however, was already looking forward to other annexations, which were hinted at in his inaugural 
address. He meant at that time to annex California; and before the end of his administration was trying to gather Cuba into the fold. Within a few days he complained of a ring of European Powers.

"The United States was already almost surrounded by the possessions of European powers: the Canadas, New Brunswick, and Nova Scotia, the islands in the American seas, with Texas trammelled by treaties - would complete the circle."

This policy of expansion by wars of conquest on other American powers may perhaps be justified by the conditions of the time. Mexico was making almost no use of New Mexico and California. Cuba was worth more to the United States than to Spain. Nevertheless, nothing but a perversion of the language and intent of Monroe's Doctrine could in any way make it cover these ambitious plans. Monroe made no pledge that the United States would not annex territory, but he based his whole theory upon the moral and international privilege of states to form their own governments and hold their own territory. If Polk sinned, he sinned without the angel guardianship of James Monroe.

When, in 1846, Polk forced war on Mexico, it was useless for him to insist that he was building on the same foundations as Monroe and John Quincy Adams. The other Latin-American powers looked upon the Mexican war as a warning that their turn might come next. Polk's settlement of the Oregon question in 1846 was statesmanlike; the compromise was common sense: for in that controversy he was confronting a first-class power able to defend its rights, a power which was no party to the Monroe Doctrine. One evidence that Polk had, after all, a conscience and a sense of moral duty is, that in 1848, when it seemed possible to annex the whole of Mexico, he refused to do so, because he had made a public pledge that it was not the purpose of the United States to destroy the Mexican Republic.

\section{THE POLK DOCTRINE (1845-1849)}

Polk's first annual message, December, 1845, contained what aimed to be a restatement of Monroe's Doctrine to meet the changed conditions. Polk was in excellent Monroe form; he 
appealed to the Doctrine of Two Spheres; he denounced the European Political System; he especially warned Europe to refrain from planting colonies in North America. The significant parts of his message are as follows:

“This Government has never interfered with the relations subsisting between other governments. We have never made ourselves Two

Spheres.

parties to their wars or their alliances; we have not sought their territories by conquest; we have not mingled with parties in their domestic struggles. ... We may claim on this continent a like exemption from European interferences.

"The nations of America are equally sovereign and independent with those of Europe. They possess the same rights, independent No Inter- of all foreign interposition, to make war, to conclude vention. peace, and to regulate their internal affairs. The people of the United States can not, therefore, view with indifference attempts of European powers to interfere with the independent action of the nations on this continent.

"The American system of government is entirely different from Political that of Europe. ... We must ever maintain the System. principle that the people of this continent alone have the right to decide their own destiny.

"Should any portion of them, constituting an independent state, propose to unite themselves with our Confederacy, this Annezation. will be a question for them and us to determine without any foreign interposition. We can never consent that European powers shall interfere to prevent such a union because it might disturb the 'balance of power' which they may desire to maintain upon this continent. Near a quarter of a century ago the principle was distinctly announced to the world, in the annual message of one of my predecessors. . . .

"This principle will apply with greatly increased force should any European power attempt to establish any new colony in Coloniza- North America. In the existing circumstances of tion. the world the present is deemed a proper occasion to reiterate and reaffirm the principle avowed by Mr. Monroe and to state my cordial concurrence in its wisdom and sound policy. The reassertion of this principle, especially in reference to North America, is at this day but the promulgation of a policy which no European power should cherish the disposition to resist. . . . It should be distinctly announced to the world as our settled policy that no future European colony or dominion shall with our consent be planted or established on any part of the North American continent." 
On their face the events of 1845 closely resemble those of 1823. Like Monroe, Polk intended that his message should be a warning that the United States meant to have Oregon. Like John Quincy Adams he referred back to Monroe's message as a fountain of authority. Just as in 1824, a resolution was. introduced into Congress to back up the President's utterance; and like Clay's resolution this one failed. John Quincy Adams, still alive and in Congress, records that " $\mathrm{I}$ approved entirely of Mr. Polk's repeated assertion of the principle" of colonization.

A second time Polk appealed to the country to support him in unusual policies when, in a message of April 29, 1848, he favored the annexation of Yucatan. It appeared that some people in that province of Mexico were so harassed by Indian insurrections that they proposed to transfer the "dominion and sovereignty of the peninsula" to the United States ; or, failing that, to Spain or England. Polk refers back both to Monroe's Monroe Doctrine of 1823, and also to his own Monroe Doctrine of 1845 , and argues that:

"Our own security requires that the established policy thus announced should guide our conduct, and this applies with great force to the peninsula of Yucatan. It is situate in Colony in the Gulf of Mexico, on the North American continent, Yucatan. and, from its vicinity to Cuba, to the capes of Florida, to New Orleans, and, indeed, to our whole southwestern coast, it would be dangerous to our peace and security if it should become a colony of any European nation."

This proposition led to a discussion at large in the Senate on the Monroe Doctrine, for the first time since the Panama Conference of 1826 ; it was in this debate that Calhoun stated the circumstances of the discussion in Monroe's Cabinet of which he was a member. The episode raised the interesting question, which is still not decided, whether a Latin-American State might of its own free will accept the dominion of an European nation. It is hard to see how Monroe's declaration would stand in the way of such action. On the other hand, if the ultimate purpose of the Monroe Doctrine is to prevent the formation of new territorial combinations which might be hurtful to the United States, such a transfer could not be allowed. The Yucatanese, however, were palpably not serious, and the suggestion was speedily withdrawn by them. 


\section{AMERICANISM IN EUROPE (1830-1851)}

Polk was such a masterful President, so resolute and so successful, that he quite overshadowed his Secretary of State, Buchanan. In the next administrations of Taylor and Fillmore, the Presidents were weaker and the active work of their diplomacy is connected with the names of their three Secretaries of State, - Clayton, Webster, and Everett. They had to face the difficulties of the Isthmus question and the $\mathrm{Cu}$ ban question, and to them also came the disagreeable results of the great series of European revolutions in 1848 .

Most thinking Americans in this period felt that they were the political teachers of the world. The undeniable success of the great American federation made republican government and federal government seem to them the normal methods of carrying on the affairs of the world. The American Revolution left almost a permanent feeling that the British monarchy had been worsted, and that monarchies of all kinds were unnatural and could not long endure. The one federal republic of Europe was Switzerland, which was little known in the western hemisphere, but which in 1848 adopted a strong federal constitution on the general model of the United States of America. American democratic ideas attracted the attention of European travellers and publicists. De Tocqueville's book on Democracy in America (1835) still remains one of the keenest and most appreciative accounts of the spirit of American government, though Americans took its criticisms in no friendly spirit. The Revolution of 1830 in France was in part engineered by Lafayette, who was accepted by the American people as one of their own heroes. Observing foreign travellers, like the Duke of Saxe-Weimar and Frederika Bremer and Sir Charles Lyell, made the country and its institutions known throughout Europe.

The Americans hardly returned these civilities. They did not understand that Great Britain by the Reform Act of 1831 had been changed from an aristocracy into a middle-class democracy, and that the advance of manufactures was developing a working class which was demanding a share of the political power. Neither did they comprehend the critical situation of France, Austria, Hungary, and Italy, or foresee the storm which burst upon Europe in the year 1848. American democ- 
racy, in some instances preached by Europeans who had lived in America, had great influence in a movement which at first seemed likely to destroy the reigning houses of the Continent.

After a few months the rising ceased in Europe. In Germany a Parliament was gathered at Frankfort which tried to combine the functions of the Philadelphia Convention of 1787 and the French Convention of 1793 - to govern and at the same time to frame a constitution. That effort failed. In France a republic was set up which within a few months elected as its President Louis Napoleon. In 1851 he arrested the representatives of the people, shot down Frenchmen and French women in the streets of Paris, and a few months later declared himself the Emperor Napoleon III. He was duly recognized as such by the United States, but was looked upon in America as a usurper and a despot.

\section{ISTHMUS CANAL (1848-1849)}

One of the notable incidents of Polk's administration was a treaty proposed by the Republic of New Granada in 1846, and ratified in Washington in 1848, whereby

"The United States guarantee, positively and efficaciously, to New Granada, by the present stipulation, the perfect neutrality of the before-mentioned isthmus, with the view that the free transit from the one to the other sea may not be interrupted or embarrassed in any future time

Guarantee of Isthmus Route. while this treaty exists; and, in consequence, the United States also guarantee, in the same manner, the rights of sovereignty and property which New Granada has and possesses over the said territory."

The question of an Isthmian canal as a source of difficulty between Europe and America goes back to the seizure by English freebooters of logwood settlements on the Gulf coast of the Isthmus, which developed into the so-called colony of Belize. By treaties of 1783 and 1786 the English agreed to give up this foothold; but these promises were never carried out.

The researches of Alexander von Humboldt called the attention of the world to the possibility of an Isthmus Canal, and it was discussed in the Panama Congress of 1826. In Jackson's 
administration a resolution was passed by the House (1835), expressing the interest of the United States government; but it was not till the conquest of California and the discovery of gold there in 1848 that the Isthmus became a part of the most available highway between the east and west coasts of the United States.

The passage of American citizens and property, principally through Nicaragua and the Colombian district of Panama, brought clearly into light two complications attending any water route that might be constructed from ocean to ocean. The first was that the ownership of every possible route was in the possession of some Latin-American state. The second was that an Isthmian canal concerned the commerce of all nations and was not considered an interest peculiar to any American state or states. From 1826 to 1903 Isthmus states made a succession of grants and charters to European and American companies who hoped to build the canal. There was also a succession of controversies between the United States, as the principal American commercial power, and Great Britain, which was the principal European commercial power, and at the same time the second American power in influence. Additional point was given to both these groups of controversies by the little British settlement of Belize, which by this time had no other reason for being than that it gave England a territorial grip on the Isthmus. In 1835 the people of Belize took on themselves to form a local government, which they called British Honduras, and to claim the strip commonly called the Mosquito Coast, southward to the San Juan River.

The treaty with New Granada was proposed in 1846 because the Granadians as they explained were afraid of Great Britain.

"A preconceived and long meditated intention of grasping the most mercantile spots of America, putting the competition of the Danger United States out of the question, and dictating her from Great will as a law in all matters concerning the consumpBritain. tion of foreign commodities. ... Great Britain would, in effect, virtually acquire a complete ascendancy over all America. . . . This dominion or ascendancy would be equally ruinous for the commerce of the United States, and for the nationality of the Spanish-American republics ; most direful for the cause of democracy in the new world ; and constantly disturbant of public peace in this our continent. 
"From these facts and general considerations may be inferred the urgent necessity in which the United States are, of interposing their moral influence, and even their material strength, between the weakness of the new republics and the ambitious views of the commercial nations of Europe, and particularly of Great Britain. ... The guar-

Protection

by the

United

States. anty of territorial possession, to be given by the United States, ought to be incidentally introduced in treaties of commerce, as a part of and subordinate to them; but this should be done so that at the same time that the freedom of the seas should be assured, the nations of Europe should be compelled to abandon their antiAmerican plans, and Great Britain her plans of territorial encroachments."

These arguments are a plea for protection, not against invasion but against commercial oppression. Apparently the supposed danger to the Isthmus was an afterthought, particularly in view of the faet that the United States in 1849 formally invited Great Britain tojoin in the guaranty. Hence the treaty can hardly be considered an expression of the Monroe Doctrine.

The British accupation of Belize and the Mosquito Coast was much móre significant. The British seized San Juan near the mouth of the river, held it for some years, and baeked up Costa Rica in claims to stretches of Nicarggua which woutd control any Canal constructed on the Nicaragua route. Hence the government of Nicaragua formally appealed to the United States for protection in 1847. In 1849 the British took possession of Tigre Island on the west coast of Honduras. The only explanation of this series of territorial advances was that Great Britain intended to control the Nicaragua Isthmian route completely; while the United States had only a general right of protection over the Panama route. Here seemed to be a clear case for Latin-Americans of that "oppressing them, or controlling in any other manner their destiny" by any European power, which Monroe had so reprehended. Though the controversy for the moment affected only the SpanishAmerican states which held territory available for a canal, the principle that the United States had a right to secure special concessions and to build a canal affected all Latin America. 


\section{CUBA (1846-1851)}

By other means than messages officially mentioning Monroe's action, President Polk showed his conviction that, - whatever the Monroe Doctrine meant, - it did not mean that the United States was under obligation to withhold from annexing any territory that she desired. The annetion of Texas was in form and in spirit not an invasion of Mexican rights, for Texas was actually an independent nation; and the-ineorporation of Pexas was not an international affront to Mexico. The Oregon contro was settled by a compromise which reeognized the truth that the United States could not lay claim to the wote of Oregon simply on the ground that Monroe had objected in 1823 to Russian colonization. Nevertheless, the claim that Texas extended to the Rio Grande, and the forcible cenquest of New Mexico and California in 1846, were notices served upon the whole world that, while the United States felt bound to prevent aggressions by European eountries upon Latin-American States, she recognized no such obligations upon herself. Monree's declaration had in it, as we have seen, a strong dash of altruistic sentiment, of good will to the Latin-Americans, of desire to benefit mankind. The Polk Doctrine was throughout one of self-interest; it was the argument of the strong to the weak.

This tendency was heightened by a new point of view toward Cuba. Secretary Buchanan in behalf of the President on June 17, 1848, instructed our minister to Spain to procure a purchase.

"You might introduce the subject by referring to the present distracted condition of Cuba, and the danger which exists that the Purchase of population will make an attempt to accomplish a revoCuba. lution..... You may then touch delicately upon the danger that Spain may lose Cuba by a revolution in that Island, or that it may be wrested from her by Great Britain. . . . You might assure him, that whilst this Government is entirely satisfied that Cuba shall remain under the dominion of Spain, we should in any event resist its acquisition by any other nation. . . . You might cite as a precedent, the cession of Louisiana to this country by Napoleon, under somewhat similar circumstances, when he was at the zenith of his power and glory. . . . The President would be willing to stipulate for the payment of one hundred millions of 
dollars for the island, and its dependencies, in ten equal annual installments. This, however, is the maximum price."

The only reply that could be got from the Spaniards was that -

"Sooner than see the island transferred to any power, they would prefer seeing it sunk in the ocean."

After the failure of Polk's attempt to purchase Cuba, the annexation spirit showed itself in a different form. Native Cubans came over to the United States and organized expeditions and invasions by bands of sympathizers, commonly called "filibusters", - the old method attempted by Miranda against Venezuela in 1806. Narcisso Lopez, a Venezuelan by birth, was the principal leader in filibustering expeditions to Cuba ; in 1849, 1850, and 1851 he set out with armed men to set free an island which showed little desire to be free.

\section{SYMPATHY WITH HUNGARY (1849-1850)}

American sympathy with European democracy was no breach of the Monroe Doctrine, but American aid and comfort to a budding European republic might fairly be considered a violation of the Doctrine of the Two Spheres. The Revolution of Hungary in 1848 gave offion for the attempt of the United States to affect European affairs. The Hungarians were a gifted, high spirited, and intensely aristocratic people. Throughout their national history they had been as far removed from republicanism as any country in Europe. When the Hungarians rose against their masters, the Austrians, and proclaimed a republic, they drew the sympathies of President Taylor's Administration. In 1849 he commissioned Dudley Mann to go to Hungary -

"With power to declare our willingness promptly to recognize her independence in the event of her ability to sustain it."

Mann was a pompous and incapable agent, but even he could see when he arrived on the scene that the republic could not last. It was shortly overthrown by Russian armies, poured in on the invitation of the young Emperor, Francis Joseph. The Austrian chargé at Washington, Huelsemann, protested at Mann's instructions : 
"This language was offensive to the imperial cabinet, for it designates the Austrian Government as an iron rule, while it represents the rebel chief, Kossuth, as an illustrious man ; while improper expressions are introduced in regard to Russia, the intimate and faithful ally of Austria."

Daniel Webster, Secretary of State, replied in a strain which was thought by many persons to be intended as proof that a Whig Secretary of State knew how to make the American Eagle scream.

"Francis I is reported to have declared in an address to the Hungarian Diet, in 1820, that 'the whole world had become foolish,

Criticisms

of the

United

States

Deprecated. and, leaving their ancient laws, was in search of imaginary constitutions.' These declarations amount to nothing less than a denial of the lawfulness of the origin of the Government of the United States, since it is certain that that Government was established in consequence of a change which did not proceed from thrones, or the permission of crowned heads. ... .

- "The power of this Republic, at the present moment, is spread over a region, one of the richest and most fertile on the globe, and of an extent in comparison with which the possessions of the house of Hapsburg are but as a patch on the earth's surface. . . . Nevertheless, the United States have abstained, at all times, from acts of interference with the political changes of Europe.

Sympathy

with

European

Democrats. They can not, however, fail to cherish always a lively interest in the fortunes of nations struggling for institutions like their own. But this sympathy, so far from being necessarily a hostile feeling toward any of the parties to these great national struggles, is quite consistent with amicable relations with them all."

The whole matter would have gone over, but for the emotional effect of a visit by Kossuth, the great Hungarian leader, who was formally invited by Congress to visit America, and was received by both Houses in the Capitol in 1852. Lewis Cass, then Senator, urged in a public meeting that the United States intervene in Hungary. Senator Seward came forward as the special friend of Kossuth and the advocate of some sort of a protest, if not of intervention. His argument was that the mission of the United States was to advance the cause of liberty. Just what Seward hoped to do he never made clear; but he appears to have thought that Austria would give up the re- 
conquered kingdom of Hungary if the United States strongly expressed disapproval.

Kossuth toured the country, everywhere asking for sympathy, money, and influence which would make Congress act. Sympathy was plentiful, money subscriptions moderate, and there was no public sentiment for intervention. Henry Clay, who had been as strong an expansionist as any in the country, on his deathbed received Kossuth and warned him against such a hope.

"Far better is it for ourselves, for Hungary, and for the cause of liberty, that, adhering to our wise pacific system, and avoiding the distant wars of Europe, we should keep our lamp burning brightly on this Western shore, as a light to all nations, than to hazard its utter, extinction amid

United

States at

Home. the ruins of fallen or falling republics in Europe."

An aftermath of this controversy was the case of Koszta, one of the Hungarian patriots, who was seized by an Austrian man-of-war in the harbor of Smyrna in 1853. Captain Ingraham of the American sloop-of-war St. Louis demanded that Koszta be given up, because he had lived in the United States two years and had filed his first papers for naturalization. Secretary Marcy backed up Captain Ingraham, and made a labored argument to the effect that Koszta had established a claim to protection.

"Whenever, by the operation of the law of nations, an individual becomes clothed with our national character, be he a native-born or naturalized citizen, an exile driven from his early home by political oppression, or an emigrant enticed from it by the hopes of a better fortune for himself and his posterity, he can claim the protection of this govern-

Acquirement of National Character. ment, and it may respond to that claim without being obliged to explain its conduct to any foreign power."

The upshot was that Koszta was allowed to go free; but the attitude of the United States with regard to Hungary gave lasting offense to Austria.

\section{CLAYTON-BULWER TREATY (1848-1850)}

Clayton, as Secretary of State, set himself systematically to counteract the British influence in Central America. June 21, 
1849, Hise, our representative in Nicaragua, took the responsibility of negotiating a treaty by which the United States was to have the sole right to construct an Isthmian road or canal through the territory of that republic. Another diplomat, Squier, secured a treaty from Honduras for the cession of Tigre Island, which the British at the same time were claiming. Squier also secured a convention with Nicaragua, ignoring the unratified and unauthorized treaty with Hise. These documents were all collected in Washington and held as an offset to the British claims and treaties. The result was a sort of deadlock in which neither England, the United States, nor the Isthmus powers could accomplish anything toward a canal.

The deadlack was broken by the Clayton-Bulwer Treaty of 1850. The purpose of the treaty was very simple: it was practically an agreement by which any canal or ine of communication across any part of the Isthmus should be controlled jointly by Great Britain the United States, and any European powers who might choose to come into the combination. Jointly, they were to guarantee the neutrality and free use of the canal. The most significant articles are as follows:

"The Governments of the United States and Great Britain hereby declare that neither the one nor the other will ever obtain

No Occupa-

tion or

Coloniza-

tion of

Central

America. or maintain for itself any exclusive control over the said ship canal; agreeing that neither will ever erect or maintain any fortifications commanding the same, or in the vicinity thereof, or occupy, or fortify, or colonize, or assume or exercise any dominion over Nicaragua, Costa Rica, the Mosquito coast, or any part of Central America ; nor will either make use of any protection which either affords or may afford, or any alliance which either has or may have to or with any State or people, for the purpose of erecting or maintaining any such fortifications, or of occupying, fortifying, or colonizing Nicaragua, Costa Rica, the Mosquito coast, or any part of Central America, or of assuming or exercising dominion over the same. . . .

"The contracting parties further engage that when the said Protection of the Canal. canal shall have been completed they will protect it from interruption, seizure, or unjust confiscation, and that they will guarantee the neutrality thereof, so that the said canal may forever be open and free, and the capital invested therein secure. . . .

"The Governments of the United States and Great Britain 
having not only desired, in entering into this convention, to accomplish a particular object, but also to establish a general principle, they hereby agree to extend their protection, by treaty Protection of stipulations, to any other practicable communications,

Panama.

whether by canal or railway, across the isthmus which connects North and South America, and especially to the interoceanic communications, should the same prove to be practicable, whether by canal or railway, which are now proposed to be established by the way of Tehuantepec or Panama."

\section{THE MONROE DOCTRINE IN THE TREATY}

Then, and since, the Clayton-Bulwer Treaty has been attacked as an abrogation of the Monroe Doctrine. It is hard to make out that it is an infringement on the original patent of Monroe. The intervention clause was not involved. The treaty gave no sanction to attacks on the sovereignty or welfare of the Latin-American powers: for Colombia, Nicaragua, and Honduras were all eager that a canal should be constructed through their territory. Nor was the treaty directed in any way to colonization; its express purpose was to prevent England getting a separate foothold on the Isthmus. It could hardly be considered a transfer of the political system of Europe to the New World. The weakness of the treaty, which gave rise to ten years of controversy, was that it used an uncertain phrase about the existing British settlement of Belize. When ratifications were exchanged, the British envoy filed a declaration in the words -

“The undersigned, Her Britannic Majesty's plenipotentiary, has received Her Majesty's instructions to declare that Her Majesty does not understand the engagements of that convention to apply to Her Majesty's settlement at Honduras, or to its dependencies."

The British government afterward held that the Bay Islands to the east of the Honduras coast were such "dependencies," and continued their hold on the Mosquito coast, although it had been expressly excepted by the treaty. Rival views as to the Belize question kept the two powers in a nervous state, till, in 1860, Great Britain for the time being gave up her claim to the Mosquito Coast. The treaty, which was several times in danger of breaking down, continued as a binding obligation between the two powers until abrogated by mutual consent in 1901 . 
Reverdy Johnson, who was the Attorney-General of President Taylor, in a letter addressed to Clayton, (December 30, 1853) says that President Taylor in his last days looked upon the colonization clause as applying to the Isthmus and -

"Had firmly resolved, by all constitutional measures in his Free Passage of the attempted, considering, as he did, that all the passages power, to prevent such aggression if any should be Isthmus. through the Isthmus should be kept free, to enable us to retain our possessions in the Pacific."

In a letter from London (January 6, 1854), Buchanan, who was then minister to Great Britain, speaking of the Monroe Doctrine said :

"While this doctrine will be maintained whenever, in the opinion of Congress, the peace and safety of the United States render this Favoring necessary, yet to have acted upon it in Central AmerPeace. ica might have brought us into collision with Great Britain, an event always to be deprecated, and, if possible, avoided.

"We can do each other the most good, and the most harm, of any two nations in the world, and, therefore, it is our strong mutual interest, as it ought to be our strong mutual desire, to remain the best friends. To settle these dangerous questions both parties wisely resorted to friendly negotiations, which resulted in the convention of April, 1850. ... Surely the Mosquito Indians ought not to prove an obstacle to so happy a consummation."

The Clayton-Bulwer Treaty, however, was in close relation to Monroe's theory of Latin-American policy ; for it deliberately recognizes Great Britain as an American power, having in the Isthmus question equal interests and weight with the United States. This was at that time the truth. Great Britain was the first shipping power in the world and the United States was the second. An Isthmus canal would serve them about equally, for trade to the west coast of the two Americas and with the Orient. The United States extended from ocean to ocean and so did Great Britain, whose title to what soon became British Columbia was admitted by the Oregon Treaty of 1846 . The United States possessed the north coast of the Gulf of Mexico; but Great Britain held Jamaica and other West India islands, and also the small but important area of Belize. The only infraction of the Monroe Doctrine by the ClaytonBulwer Treaty was the acknowledgment that the United States 
was not the only non-Latin power in America. In many ways it was a compliment and advantage to the United States to obtain recognition as the equal of Great Britain in American concerns. The great defect of the Clayton-Bulwer Treaty was that it did not bring about the expected Canal, and later proved to be a stumbling block in the way of any Canal.

\section{THE AFTERMATH OF CONQUEST (1846-1852)}

The general effect of Polk's policy the spirit of the American people was far better than it deserved to be. The nation rejoiced in the addition within eight of Texas, Oregon, New exieo, California, and the Gadsden Purchase of 1853. The Pacific Coast was doubled in entent The great continental empire of the United States was rounded out. Steps were taken to connect the eastern and western coast by an Isthmian canal; and both the possession of the Pacific coast and the hope of a Canal opened the door to magnificent commerce with the Orient. If England had any designs on Califormia, they had been prevented. Anglo-Saxondom had shown its superiority to Latin-Americanism wherever they collided. England had been willing to acknowledge the United States as a sister American power which was to share in the commercial future of the Americas. The Isthmus powers welcomed the prospect of a canal.

The three danger spots were Cuba, Nicaragua, and joint control. The spirit of annexation was still lively, and Cuba was especially mixed up with the European relations of Spain. Nicaragua could never be content while much of the San Juan coast was claimed by Great Britain - a state of things which the Clayton-Bulwer Treaty did not remedy. Joint control between the two powers was like joint occupation of Oregon, a temporary arrangement. The chief defect of Polk's and Taylor's policies was a national excitement about American interests and a national feeling that the United States was entitled to a free hand in American affairs.

Why should there any longer be a Monroe Doctrine? Was not the United States able to take care of herself? Could not her rights and interests in America be protected simply by her own power and conceptions of right and wrong? 


\section{Chapter IX}

\section{DOCTRINE OF AMERICAN SUPREMACY 1853-1861}

FRAMERS OF OUR FOREIGN POLICY (1853-1861)

The conditions of the times forced the country to think in terms of foreign relations. Schemes of annexation were in the air. Americans had a sense of responsibility for extending the blessings of their government, and for thwarting the nefarious plans of foreign peoples. The spirit of the country was honestly for expansion, and against recognizing too many rights of weaker neighbors.

The heads of the government at that time had a great opportunity to turn this torrent of public sentiment whither they would. The election of President Pierce in 1852 meant the elevation to great power and responsibility of a weak man who had no very clear conceptions of international law and relations. He provided himself with an excellent Secretary of State, Marcy, who had no previous experience in diplomacy or international law, but was a cautious man who knew when to stop. Perhaps Pierce's ablest and most vigorous adviser was Jefferson Davis, Secretary of War.

Buchanan, who became President in 1857, was one of the most experienced men in public life. He had been Minister to Russia, Secretary of State, and Minister to England. He was supposed to be astute, but he was a strong party man, and did not realize the currents of public feeling. His Secretary of State, Cass, was one of the most adventurous of the politicians of that period. Buchanan had taken part in the discussions of the Monroe Doctrine in 1826, and Cass was one of the senators who ratified the Clayton-Bulwer Treaty. All four men were permeated with the idea that it was a political duty to find a territorial compensation for the accident by which Cali- 
fornia had been taken from the slave-holders. All of them strongly felt that the British government was acting against the spirit and intent of the Clayton-Bulwer Treaty. All were interested in the annexation of Cuba, and perhaps Mexico. They were all fond of phrases and all tried to stretch the overused term, "Monroe Doctrine," to cover their plans.

In the Senate, the two men besides Cass who were most interested in foreign policy were Stephen A. Douglas of Illinois and William H. Seward of New York. Douglas represented the theory that whatever the United States desired was good enough law for him; and that other nations must accept it. Conditions, limitations, restrictions, were words that he hardly understood. He hated England vindictively and was one of the first men to insist publicly that the time was approaching when the English colonies must cease in America. He was the first powerful exponent of what came to be called "Manifest Destiny." Seward was a more highly organized man, ardent and impulsive, fond of rhetoric and convinced that it had great effect in international relations. He was by nature as eager as Douglas to see his country enlarged; and in his later career as Secretary of State, he was the most passionate expansionist of his time. Yet he and his co-workers were the stoutest obstacle to the plans of Pierce and Cass; for as antislavery men they fought every effort to annex slave-holding areas.

\section{CONDITIONS OF AMERICA}

The world was drawing closer together. By 1853, steamer lines were established to Europe and American packet ships were found in every large port of the world. Steamers ran to the West Indies and communications farther south were somewhat improved. The problem of quick transportation to California had been solved by two groups of American capitalists. The first operated the Accessory Transit Company, which carried passengers across the Isthmus of Nicaragua in connection with steamers at both ends. The other was the Panama Railroad, begun in 1850 and completed in 1855 as a link in the quickest and most convenient route from the Atlantic and Gulf Coast to the Pacific Coast. Through these lines the physical connection with the Latin-Americans became closer than ever before. Mexico, Brazil, and the Argentine began to make 
greater use of their wealth of fertile land. The Amazon and La Plata rivers were explored and made arteries for transportation.

Some evidence appeared of a desire of the United States to win back the lost confidence of the Latin-Americans. President Taylor in his annual message of 1849 made an interesting suggestion:

"The United States stand as the great American power, to which, as their natural ally and friend, they will always be disposed first Friendly to look for mediation and assistance in the event of Mediation. any collision between them and any European nation. As such we may often kindly mediate in their behalf without entangling ourselves in foreign wars or unnecessary controversies. Whenever the faith of our treaties with any of them shall require our interference, we must necessarily interpose."

Taylor's idea was in essence that the United States might act as a friend to both sides when there were difficulties with European powers. The United States was to be called in as the natural mediator. The attitude of the United States to Cuba and the Isthmus stood in the way of such kindliness. The necessity of holding California, which showed some symptoms of a willingness to take care of herself, focussed attention upon the Isthmus and the Isthmian canal, as the principal American question of the time.

\section{PROPOSED JOINT GUARANTY IN CUBA (1851-1852)}

The filibustering revolutions in Cuba led, in 1852, to the renewal of an old notion for a joint guaranty by France and England, to which, it was now suggested, the United States would be a natural party. The significant text of the proposal runs as follows :

"The high contracting parties hereby severally and collectively disclaim, both now and for hereafter, all intention to obtain posNo Anneza- session of the island of Cuba; and they respectively tion or $\quad$ bind themselves to discountenance all attempt to that Control.

effect on the part of any power or individuals whatever.

"The high contracting parties declare, severally and collectively, that they will not obtain or maintain, for themselves or for any one of themselves, any exclusive control over the said island, nor assume nor exercise any dominion over the same." 
The crux of this ingenious proposal was that the United States should prevent England and France from interfering with the destinies of Cuba, by herself agreeing not to disturb those destinies. December 1, 1852, Secretary Everett courteously declined this offer, upon the open ground that Cuba was much more important to us than to any other great power. The transfer of Cuba to any European power, he said -

"We should view ... in somewhat the same light in which France and England would view the acquisition of some important island in the Mediterranean by the United States, Two with this difference, it is true: that the attempt of Spheres. the United States to establish themselves in Europe would be a novelty, while the appearance of a European power in this part of the world is a familiar fact."

Everett, after putting the technical objection that such joint action would be contrary to the principle that the United States should make no political alliances with a European power, manfully faces the main issue.

"The United States, on the other hand, would, by the proposed convention, disable themselves from making an acquisition which might take place without any disturbance of existing foreign relations, and in the natural order of things. The island of Cuba lies at our doors. It commands

Significance to the $\mathrm{U} . \mathrm{S}$. the approach to the Gulf of Mexico, which washes the shores of five of our States. It bars the entrance of that great river which drains half the North American continent, and with its tributaries forms the largest system of internal water-communication in the world. It keeps watch at the door-way of our intercourse with California by the Isthmus route. If an island like Cuba, belonging to the Spanish crown, guarded the entrance of the Thames and the Seine, and the United States should propose a convention like this to France and England, those powers would assuredly feel that the disability assumed by ourselves was far less serious than that which we asked them to assume."

This is not Monroe's Doctrine and it is hardly Polk's doctrine; it closely approaches the frame of mind to which Secretary Evarts, in 1879, gave the name of "Paramount Interest." It points to an annexation of Cuba which sixty-three years later has not yet come to pass. 


\section{THE CASS DOCTRINE (1853-1858)}

The relation of the Clayton-Bulwer Treaty to inter-American policy was brought up in 1853, and for the third time the Senate debated the terms and applications of the Monrce Doctrine. Another effort was made to give it a legislative form when Cass, of Michigan, introduced the following joint resolutions :

" 'The American continents, by the free and independent condition which they have assumed and maintain, are henceforth not Coloniza- to be considered as subjects for future colonization tion. by any European power.' And while 'existing rights should be respected,' and will be by the United States, they owe it to their own 'safety and interests' 'to announce, as they now do, that no future European colony or dominion shall, with their consent, be planted or established on any part of the North American continent.' And should the attempt be made, they thus deliberately declare that it will be viewed as an act originating in motives regardless of their 'interests and their safety', and which will leave them free to adopt such measures as an independent nation may justly adopt in defense of its rights and its honor.

". . . That while the United States disclaim any designs upon the Island of Cuba, inconsistent with the laws of nations and with their Cuba not duties to Spain, they consider it due to the vast imfor Others. portance of the subject, to make known in this solemn manner, that they should view all efforts on the part of any other Power to procure possession, whether peaceably or forcibly, of that Island, which as a naval or military position, must, under circumstances easy to be foreseen, become dangerous to their southern coast, to the Gulf of Mexico, and to the south of the Mississippi, as unfriendly acts, directed against them, to be resisted by all the means in their power."

These resolutions were never put to a vote; but Cass remained the champion of a sweeping doctrine, and in 1856 asserted that the Monroe Doctrine obliged the United States to resist by force the establishment of any European dominion in North America. Two notable incidents of this debate were the efforts of a rising statesman in the East and another in the West to carry the principles of American policy farther than had been dreamed by Monroe or Polk. William H. Seward was perhaps the first statesman to understand the vast significance of the American position on the west. 
"You want the commerce of the world, which is the empire of the world. This is to be looked for not on the American lakes, nor on the Atlantic coast, nor on the Caribbean sea, nor on the Mediterranean, nor on the Baltic, nor on the Atlantic ocean, but on the Pacific ocean, and its

Dominance

of the

Pacific. islands and continents. ... Open up a highway through your country from New York to San Francisco. Put your domain under cultivation, and your ten thousand wheels of manufacture in motion. Multiply your ships, and send them forth to the East."

A very different point of view was represented by Douglas. The course of action which he suggested was perfectly simple: to break with England, and to annex the whole of North and South America. In speeches of 1845 he did not spare the effete despotisms of the old world.

"Europe is ... tottering on the verge of dissolution. When you visit her, the objects which enlist your highest admiration are the relics of past greatness; the broken columns erected to departed power. . . . They bring up the

Weakness memories of the dead, but inspire no hope for the living! Here everything is fresh, blooming, expanding, and advancing."

"I would blot out the lines on the map which now mark out national boundaries on this continent, and make the area of liberty as broad as the continent itself. I would not suffer petty rival republics to grow up here, engendering jealousy of each other, and interfering with

Annexation of all Americas. each other's domestic affairs, and continually endangering their peace. I do not wish to go beyond the great ocean - beyond those boundaries which the God of nature has marked out, I would limit myself only by that boundary which is so clearly defined by nature."

"Our federal system is admirably adapted to the whole continent; and, while I would not violate the laws of nations, nor treaty stipulations, nor in any manner tarnish the national honor, I would exert all legal and honorable means to drive Great Britain and the last vestiges of royal authority

Expulsion of Great Britain. from the continent of North America, and extend the limits of the republic from ocean to ocean. I would make this an ocean-bound republic, and have no more disputes about boundaries."

A Texan Senator commented upon Cass' position in the drastic argument that the Monroe Doctrine did not mean "that every settlement in any sand-bank in this continent is an offense which is to result in war." Cass developed his doctrine in a 
speech of 1856, and as Secretary of State under Buchanan, had opportunity to phrase it officially. The United States, he said (October 21, 1858):

"Will not consent to the subjugation of any of the independent states of this continent to European powers, nor to the exercise of a protectorate over them, nor to any other direct political influences to control their policy or institutions."

In a despatch of September 28, 1860, Cass applied the Monroe Doctrine to any possession of American territory by a European power.

\section{DESIGNS ON CUBA (1853-1854)}

The question of expansion was deliberately raised by President Pierce in his inaugural address (March, 1853):

"The policy of my Administration will not be controlled by any timid forebodings of evil from expansion. Indeed, it is not to be Annexation disguised that our attitude as a nation and our posiof Cuba Essential. tion on the globe render the acquisition of certain possessions not within our jurisdiction eminently important for our protection, if not in the future essential for the preservation of the rights of commerce and the peace of the world. Should they be obtained, it will be through no grasping spirit, but with a view to obvious national interest and security, and in a manner entirely consistent with the strictest observance of national faith."

To the Spanish mind this was like a polite intimation to a neighbor that his house will pass into your possession before Christmas. Marcy waited for a good opportunity to take advantage of some technical blunder through which he might browbeat Spain into a sale. The occasion seemed to offer in 1854, when Buchanan, Soule, and Mason, Ministers of the United States to England, Spain, and France, were authorized to suggest a policy on the subject. They produced a document commonly called the "Ostend Manifesto" of which the critical phrases are the following:

"But if Spain, dead to the voice of her own interest, and actuated by stubborn pride and a false sense of honor, should refuse Self-preser- to sell Cuba to the United States, then the question vation. will arise, What ought to be the course of the American 
government under such circumstances? Self-preservation is the first law of nature, with States as well as with individuals. All nations have, at different periods, acted upon this maxim. Although it has been made the pretext for committing flagrant injustice, as in the partition of Poland and other similar cases which history records, yet the principle itself, though often abused, has always been recognized. . . . After we shall have offered Spain a price for Cuba far beyond its present value, and this shall have been refused, it will then be time to consider the question, does Cuba, in the possession of Spain, seriously endanger our internal peace and the existence of our cherished Union?

"Should this question be answered in the affirmative, then, by every law, human and divine, we shall be justified in wresting it from Spain if we possess the power; and this upon Right of the very same principle that would justify an indi- Seizure. vidual in tearing down the burning house of his neighbor if there were no other means of preventing the flames from destroying his own home."

This early form of the "neighbor's burning house" argument, at the present time is revived to encourage interference in Mexico, Central America, and the Island of Santo Domingo. In this particular case the burning house was possible abolition in Cuba, that might endanger slavery in the United States. Whatever the occasion, this theory of the right of intervention for the defense of domestic institutions is at the opposite pole from the Monroe Doctrine as first set forth and as applied down to 1845. Pierce's scheme against Cuba failed and so did the strenuous efforts of Buchanan, renewed every year during his presidency.

\section{MINOR TERRITORIAL AMBITIONS (1853-1860)}

The expansionist statesmen of the period turned their attention in several other directions, besides Cuba, Mexico, and Central America, and were successful in one respect. The southern boundary of the United States, as described in the Mexican Treaty of 1848, proved inconvenient and caused disputes. Secretary Marcy, therefore, in 1853 authorized Gadsden, Minister to Mexico, to negotiate the purchase of a broad strip of Mexico. One purpose was to secure a favorable line for a transcontinental railroad to California. President Santa Anna consented to the transfer for a payment of $\$ 10,000,000$, though to 
this day it is uncertain whether the money ever reached the Mexican treasury. This success seems to have elated Secretary Marcy, who, in 1853 and 1855, took steps which he hoped would result in the annexation of the Hawaiian Islands, a subject which will be treated in detail farther on.

The only positive interference by the United States in South America for many years arose from the attempt of the authorities of Paraguay to close the navigation of the river Paraña in 1853. The United States ship Water Witch was fired upon while trying to ascend the river. This squabble aroused an uproar in Washington: Congress authorized the use of force, and in 1859 the President sent out a fleet of nineteen vessels before which the feeble little country yielded. The episode was tangled up by a preposterous claim on the part of an American consul, which was later thrown out by an arbitration commission. It is doubtful whether the Paraguayan government in closing the channel had gone farther than the United States government would have been justified in doing in her own waters. The remedy of force seemed out of proportion; but the Administration meant to show that the United States could not be defied by South American states.

\section{GUANO ISLANDS}

On various occasions in the fifties the United States became engaged in controversies over certain barren islands in the Pacific Ocean and the Caribbean Sea which became valuable because of the rising demand for fertilizers which could be supplied out of the accumulations of bird guano. In 1852 the Peruvian government attempted to exercise jurisdiction over the little group of Lobos Islands lying off the coast of Peru. The United States insisted that these were desert and unappropriated islands belonging to no nation; and that the first comer had the right to occupy them for the purpose of removing the guano. Americans who were the first to open the deposits would have the protection of their government.

The upshot was the passage of a federal statute in 1856 which was afterwards amended to the following form:

"Whenever any citizen of the United States discovers a deposit of guano on any island, rock, or key, not within the lawful juris- 
diction of any government, and not occupied by the citizens of any other government, and takes peaceable possession thereof, and occupies the same, such island, rock, or key may, at the discretion of the President, be

Islands appertaining to the U. S. considered as appertaining to the United States."

Several times since that statute was passed the United States has defended the temporary title to such islands against the protests of near-by Latin-American powers. A list of such island possessions is kept at the State Department, it being always understood that when the operations are completed the protecting title of the United States lapses. No effort has been made to turn any of these temporary occupations into permanent possessions, perhaps because none of them seemed suited for use as naval or coaling stations. This system of temporary title is of little significance in international relations, except as one of many proofs that the United States recognizes no sacredness of American islands outside her own boundary.

\section{DESIGNS ON THE ISTHMUS AND MEXICO (1853-1861)}

The diplomacy of President Pierce and President Buchanan was nearer to Douglas' principles than to Monroe's. 'The Isthmian Canal languished, partly because of the disputes over the Clayton-Bulwer Treaty and partly because the difficulty and expense of the scheme were more clearly realized. Some surveys were made, especially of the Nicaragua route; and a rival plan was outlined for a railroad across the Isthmus of Tehuantepec. That route was not used for many years to come.

Both on this line and on the Nicaragua route there were difficulties with the local governments, and the system of filibustering was carried to its farthest point. William Walker began in 1853 to head armed expeditions against several Central American States; and in 1855, with the aid of Cornelius Vanderbilt who was managing the transit across the Isthmus of Nicaragua, he took possession of that little country and for a short time was its dictator. He was warmly supported in the United States and his government was for a time recognized by President Pierce. The Central American states and other Latin neighbors looked upon this movement as pure spoliation. The rising Republican Party at home believed the whole 
thing was a movement to introduce slavery into countries which had forbidden it forty years before this time. In 1856 a naval demonstration was made by the United States on both sides of the Isthmus of Panama, as a protest against a tonnage tax laid by Colombia.

Buchanan's desire to annex Cuba caused suspicions which were strengthened by his attitude toward Mexico, which was in great confusion. In 1858 the United States for a time withdrew her minister to Mexico as a protest. The Administration then selected the régime of Juarez, one of the few Mexican Indians who had shown statesmanlike capacity. An American envoy was sent to recognize him. Buchanan recommended to Congress that -

"The Government of the United States . . . assume a temporary protectorate over the northern portions of Chihuahua and Sonora, and ... establish military posts within the same."

In December, 1859, he formally proposed to Congress a more drastic course.

"Pass a law authorizing the President, under such conditions as they may deem expedient, to employ a sufficient military force Annexation to enter Mexico for the purpose of obtaining indemnity in Mexico. for the past and security for the future. . . . Such an accession to the forces of the constitutional Government would enable it soon to reach the City of Mexico and extend its power over the whole Republic. In that event there is no reason to doubt that the just claims of our citizens would be satisfied and adequate redress obtained for the injuries inflicted upon them."

The situation was serious and Minister McLane secured from Juarez a treaty by which the United States was to allow Mexico $\$ 4,000,000$ in consideration of the right of transit across the Tehuantepec, and some commercial concessions. 'The treaty was not ratified, but Secretary Cass, through whom the negotiations passed, was the same Cass who a few years earlier pronounced such extreme views upon the authority of the United States over America. Buchanan himself took refuge in what he called the Monroe Doctrine, in his annual message of December, 1860 :

"In addition - and I deem this a most important considerationEuropean Governments would have been deprived of all pretext 
to interfere in the territorial and domestic concerns of Mexico. We should thus have been relieved from the obligation of resisting, even by force should this become necessary, any attempt by these Governments to deprive our neigh-

Traditional boring Republic of portions of her territory - a duty from which we could not shrink without abandoning the traditional and established policy of the American people."

\section{UNITED STATES IN EUROPEAN DIPLOMACY (1856-1861)}

Several circumstances besides the Hungarian episode brought the United States more closely than ever before into the combinations of European diplomacy. In 1856 the European powers invited the United States to join in the Declaration of Paris and thus make effective the proposed prohibition of privateering. It was the first time since 1823 that the United States had been asked to take part in a serious European agreement. Secretary Marcy held off, on the ground that Europe must also agree to prohibit the capture of private property at sea altogether. Apparently he had a muddled feeling that the United States had as good a right to alter the conclusions of Europe as Europe had to propose changes for acceptance by the United States. In 1857 the United States succeeded in obtaining a diplomatic triumph in the controversy with Denmark over the Sound dues. Secretary Cass refused to accept the settlement proposed by a European conference, and then made a satisfactory treaty of his own.

While the government was thus undermining the Doctrine of the Two Spheres, by showing that the United States had much in common with Europe, the American people took it for granted that the only proper government for mankind was democratic government, which was destined to extend to all parts of the world under the splendid example of the United States. They failed to see that their claim to the international right of intervention in order to keep alive a republic in Hungary, might in the long run be used as an admission of the right of Austria to intervene in Mexico in order to destroy a republic, - a complication which actually came about ten years later. The Monroe Doctrine in this period was no longer a peaceful, defensive principle, but the basis of a claim to a moral leadership by the United States not only in Latin America but in Europe. 


\section{STATUS OF THE MONROE DOCTRINE IN 1861}

At the end of Buchanan's administration in March, 1861, the original Monroe Doctrine was out of service. On one side it was weakened by the Clayton-Bulwer Treaty which recognized England as an equal party in one of the most important relations between Latin-American states and the rest of the world. Upon this pressing American question of an Isthmian Canal, the United States formed an alliance with an European power, and admitted the principle that all European powers were entitled to share in the use and protection of the Canal. This was not harmful to the Central-American states; but the continued pressure of Great Britain for control of the coast in the neighborhood of the eastern terminus of the Nicaraguan route was very unwelcome, both to the Isthmus states and to the United States. That difficulty was finally settled in 1860 by the Treaty of Managua, under which the British Government agreed to give up all claims to the Mosquito Coast. The basal principle that European powers must not seize American territory was thus consistently supported by the United States.

The concession as to the Canal was more than balanced by the radical and aggressive policy of Pierce, Marcy, Buchanan, and Cass, which could not be justified on any possible construction of the original Monroe Doctrine. These statesmen were inflamed by the easy annexations of Oregon, Texas, New Mexico, California, and the Gadsden Purchase. A very strong pressure was put on the government to annex possible or actual slaveholding territory, as a balance to the free State of California; and that accounts for the vigor of the movement of two Administrations on Cuba, Central America, and part of Mexico. The Republican platform of 1856 characterized this policy, as set forth in the Ostend Manifesto, as "the highwayman's plea that might makes right."

Outside of the Isthmus there were no serious aggressions on Latin America by Europe in this period. There was not the slightest danger of the transfer of Cuba or any other European colony in America. To a mind of Buchanan's type, this freedom from the responsibility of the Monroe Doctrine gave the opportunity to deny its basal principle - which was that the Latin-American powers must endure. True, life and property were unsafe in most of the Latin-American countries, especially 
Mexico and Central America, where the conditions were as bad as they were in 1823 or as they are in the year 1915. Yet the policy of Pierce and Buchanan, of Cass and Douglas, was a travesty on the Monroe Doctrine. They demanded that the influence, boundaries, and powers of the United States be extended indefinitely; they meant to drive out the existing and acknowledged colonies of European powers; then they hoped gradually to annex the weak and disturbed Latin-American States which had been favored and protected by the principles of Monroe and John Quincy Adams. -

The Presidents and Secretaries of State of the period seemed to assume that there was a definite body of principles, universally recognized, as to the relation of the United States to the rest of America. The truth is, however, that this abracadabra of American international policy had not then, and never has had, unalterable and unmistakable meaning; the powers especially interested in it have never fixed upon a common understanding; and even within the United States, several widely different theories were current as to the principles which the Doctrine originally contained, and as to its application to circumstances not then contemplated. There was still more uncertainty and conflict of authority as to the geographical extent of the Doctrine; some people extended it to the whole of the two Americas, including all European colonies; somè confined it to the fragments of the Spanish and Portuguese empires; and some carried it only as far as the Amazon. Indeed, both in its extent and intent, the Monroe Doctrine was not a term but a treatise; not a statement but a literature; not an event but an historic development. The term Monroe Doctrine has at various times been set up as precluding every form of interference by European powers, from kidnapping a policeman to conquering an empire; and to every parcel of territory from the Pribyloff Islands to Tierra Del Fuego. 


\section{Chapter X}

\section{HOW TO GET ON WITHOUT MONROE 1861-1869}

\section{LATIN AMERICA IN 1861}

IN the midst of the twelve years of agitation for annexations by the United States the Latin-American states were little troubled by foreign powers. The principal controversies were squabbles over ills of foreigners and of diplomatic representatives, demands for reparation, claims and negotiations for the adjustment of those claims. Forty years after Monroe's declaration, the danger had not occurred which was most in his mind. No effort and no decided threat had ever been made to invade America, except by Spain. After the recognition of the former colonies by that power, nobody had a quarrel which would have justified invasion; nobody attempted to extend the political system of Europe to the New World, or to control the Latin-American powers, or affect their destiny. The only significant naval expeditions were those of France against Mexico in 1838; two blockades of Buenos Ayres in 1838 and 1845 and that of the United States against Paraguay in 1859, which was entirely out of proportion to the offense.

The fifties was a period of weakness for Latin-America, especially in the parts of the northern continent and the West Indies closest to the United States. In the Island of Haiti, two separate negro republics were definitely established in 1844; both of them were cursed by revolutions and frequent changes of government; and neither had ever been formally recognized by our government, or allowed to exchange diplomatic representatives, though trade between them and the United States was large and profitable. Central America was in a state of great internal confusion, which was much increased by the known designs of the United States. Mexico was in an especially 
miserable condition. One of the worst consequences of the war with the United States was the destruction of the small sense of national dignity. Dictator followed dictator. Four different military leaders claimed to be president in the one year 1857. For many years there had been a Clerical Party opposed by a Popular Party which was set on confiscating the enormous property of the churches and monasteries. The critical point was reached in 1860, when the agents of a revolutionary government broke into the British legation in the City of Mexico and took securities to the value of $£ 150,000$. In 1859 Juarez ordered the confiscation of all the church property except the churches and their contents. Much of that property was mortgaged to foreign lenders and no provision was made for the interest on those loans, or the principal or interest of the public debt. Claims arose in great numbers because of seizure of property and imprisonment and harsh treatment of individuals. Private claims to the much exaggerated value of $\$ 10,000,000$ were filed at Washington.

The plan of Buchanan to prevent the despoilment of Mexico by despoiling it has already been discussed. In his annual message of 1859, Buchanan went still farther by protesting against a proposed joint European expedition into Mexico, for the purpose of collecting debts and securing indemnity, because of "our established policy, which is inconsistent with the intervention of any European power in the domestic concerns of that Republic." This doctrine as to collection of debts is a forerunner of the policy of the United States after 1895. The situation closely resembles that of Mexico from 1912 to 1915 : the country was distracted by the civil wars of rival despots; Americans and their property were ill-used; and at the same time the United States claimed a peculiar interest in Mexico, which must prevent foreign powers from taking into their own hands the protection of their subjects.

\section{SEWARD'S CONCEPTION OF AMERICA}

The point of view of the United States toward this condition of turmoil and anarchy was much altered by the coming to power of the Republican party, the inauguration of Abraham Lincoln in 1861, and his appointment of William H. Seward as Secretary of State. Seward's first principle was total opposi- 
tion to the Democratic policy of annexation, which he held to be nothing but a scheme for enlarging the slave-holding area of the United States to the disadvantage of the North. To soothe Mexico, Thomas Corwin of Ohio was sent down - the Corwin who, in 1846, had advised the Mexicans to welcome his countrymen "with bloody hands to hospitable graves." All the plans against Mexico were forthwith dropped; and Canal diplomacy was for several years allowed to lapse. Seward's immediate concern was to keep up the political credit of the United States in Europe and to prevent the recognition of the Southern Confederacy by foreign powers.

Nevertheless, Seward set on foot several innovations in our diplomatic relations. However warm his interest in other republican governments, he was perfectly aware of the defects of Latin-American character, and of the consequent strain on the diplomacy of the State Department. Not long after his appointment he put into a despatch the striking passage:

"Everybody wishes the Spanish-American states well, and yet everybody loses patience with them for not being wiser, more conInstability. stant, and more stable. Such, I imagine, is the temper in which every foreign state finds itself when it proposes to consider its relation to those republics, and especially the republics of Central America. . . .

"Assure the Republic of Nicaragua that the President will deal with that government justly, fairly, and in the most friendly Friendship spirit; that he desires only its welfare and prosperand Equal- ity. Cultivate friendly dispositions there towards ity.

the United States. See that no partiality arises in behalf of any other foreign state to our prejudice, and favor, in every way you can, the improvement of the transit route, seeking only such facilities for our commerce as Nicaragua can afford profitably to herself."

Upon the question of the recognition of successive despots, Seward made it a practice to look into the method by which the dictator came to the head of the State. He several times ordered recognition to be delayed on the ground that the reigning despot was backed only by a military force and not by the "acquiescence of the people," or "general consent of the people." He clearly stated the principle of independence, which is one of those insisted on by Monroe - the right - 
"To establish and maintain its own government without intervention, intrusion, or even influence, from foreign nations, and especially from the United States."

Another notable change in the policy of recognition was that in 1862 a treaty was negotiated with Haiti, and ministers were exchanged with that country and in 1866 with Santo Domingo. This liberality toward negro republics was extended to Liberia, which was practically a dependency of the United States, but was nominally treated as an independent nation, capable of making treaties and exchanging ministers. Seward also succeeded in leasing the harbor of Mole St. Nicholas from Haiti as a naval station. The Spanish island colonies were much in Seward's mind ; and early in his diplomatic career he informed Carl Schurz, minister to Spain, that the United States -

"Have constantly indulged the belief that they might hope at some day to acquire those islands by just and lawful means, with the consent of their sovereign."

\section{EUROPEAN INVASION OF MEXICO (1861-1862)}

When the question is raised whether the Monroe Doctrine was ever really a protection to the Latin-Americans from foreign aggression, it is hard to point to any clear instance in which the remonstrance of the United States caused foreign powers to stay their hands. The withdrawal of the British claims to the Mosquito coast is apparently such a case; but it was done grudgingly and incompletely. Nevertheless, the Monroe Doctrine was often a silent influence, which seemed unnecessary because it was always in the minds of foreign diplomats. It was no accident that the year 1861, when the United States was in the midst of a fearful civil war, was selected for the only complete instance in which any foreign power has actually planted a colony in America against the will of a Latin-American state; or extended the "political system" of Europe; or "controlled the destinies" of an American power. The conclusion cannot be resisted that invasion and conquest would have happened often before and since that time but for the supposed intention and ability of the United States to prevent it.

The first thoroughgoing violation of the Monroe Doctrine in all its various forms from Monroe to Cass, was therefore an invasion of Mexico in 1861. It was a further aggravation that 
it was brought about by a combination of the three European powers, England, France, and Spain, which had considerable territory in America. The grievance of England was longcontinued aggressions on the subjects and representatives of Great Britain, rising to the point of denial of the privileges of English diplomatic representatives. The grievance of Spain was that Juarez's government refused to recognize a treaty made by the Spanish government with the rival faction. The claim of France was founded on alleged injuries to her subjects, and a refusal of Juarez to recognize the Jecker bonds, which the rival chieftain, Miramon, had issued to the amount of $\$ 15,000,000$ on the receipt of five per cent. of their face in cash. Juarez offered to repay the $\$ 750,000$, but not twenty times that sum.

The three powers started out with moderation. In a triple convention (October 31, 1861), they pledged each other as follows :

"The high contracting parties engage not to seek for themselves, in the employment of the coercive measures contemplated by No Undue the present Convention, any acquisition of territory, Influence. nor any special advantage, and not to exercise in the internal affairs of Mexico any influence of a nature to prejudice the right of the Mexican nation to choose and to constitute freely the form of its Government."

This pledge was kept by Spain and England, which joined with France in landing troops at Vera Cruz; when the Juarez government came to terms with them, they withdrew their troops. France had from the beginning intended to seize the country. November 11, 1861, the Emperor Napoleon instructed his military commander that he might need to stay, in order to give an opportunity to those Mexicans who would prefer a strong government, and in 1863 communicated to General Forey his purposes as follows:

"To establish bounds to the extension of the United States towards the South, and to prevent her from controlling the commerce of the Gulf of Mexico."

After hard fighting the French captured the City of Mexico in 1863 and called an Assembly of Notables, who elected the Archduke Maximilian of Austria, to be Emperor of Mexico. 
He arrived in 1864 and set up a government which was recognized by most of the European powers; with the aid of French bayonets, and under the direction of French officers, this nominal Empire continued until 1867.

\section{THE UNITED STATES ON MEXICO (1861-1862)}

The whole proceeding was disagreeable to the United States. When it was first rumored in 1860, Cass, as Secretary of State, wrote to our Minister in Mexico :

"While that principle denies the right of any power to hold permanent possession of any part of that country, or to endeavor by force to direct or control its political destiny, it Redress of does not call in question its right to carry on hostile Grievances. operations against that republic for the redress of any real grievances it may have suffered. But we insist that such hostilities be fairly prosecuted for that purpose and be not converted into the means of acquisition or of political control."

Later, the United States was invited to join in the armed intervention, and Seward replied in a long despatch which contains a paragraph that appears from its style to have been drawn by President Lincoln :

"The President does not feel himself at liberty to question, and he does not question, that the sovereigns represented have undoubted right to decide for themselves the fact Territorial whether they have sustained grievances, and to Advantage. resort to war against Mexico for the redress thereof, and have a right also to levy the war severally or jointly.

"Secondly, the United States have a deep interest . . . that neither of the sovereigns by whom the convention has been concluded shall seek or obtain any acquisition of territory or any advantage peculiar to itself."

In the same dispatch there is the following veiled allusion to earlier statements on the interest of the United States in LatinAmerica.

"The United States, so far as it is practicable, prefer to adhere to a traditional policy recommended to them by the Father of their Country and confirmed by a happy experience, Traditional which forbids them from making alliances with Policy. foreign nations; second, Mexico being a neighbor of the United 
States on this continent, and possessing a system of government similar to our own in many of its important features, the United States habitually cherish a decided good will towards that Republic, and a lively interest in its security, prosperity, and welfare."

One possibility which had been officially suggested in 1860 by McLane was that the United States should step in and satisfy the money claims of the intervening powers. Seward authorized Corwin to negotiate a treaty with Mexico by which the United States should guarantee interest on the whole Mexican debt for a term of years. Instead, Corwin without instructions negotiated a treaty by which the Mexicans were to receive as a loan about $\$ 9,000,000$ in money. This proposition the President submitted to the Senate which wisely refused to ratify it, for the plan was clearly unworkable.

Meantime, the recently organized Confederate States of America sent its agents to propose an alliance with the Juarez government, which, as the organ of national defense, was now the only native government in the country. One of these agents, who was markedly unsuccessful, reported back to Richmond:

"The part for the Confederate States to play in this crisis is clear to my mind. Our revolution has emasculated the Monroe Attitude of doctrine in so far as we are concerned. The Spanthe C.S.A. iards are now become our natural allies, and jointly with them we may own the Gulf of Mexico and effect a partition of this magnificent country."

Later, Confederate envoys, first to the Juarez government and then to the Empire of Maximilian, had the same cold reception: nobody in Mexico cared to give cause of offense to the Union government by the recognition of its enemies.

\section{THE SEWARD DOCTRINE (1861-1869)}

Where in this crisis was the Monroe Doctrine? Why did not the President, the Secretary of State, and our ministers abroad call the attention of European powers to this infraction of a doctrine which had been promulgated and discussed for nearly forty years? Nowhere in the correspondence of the State Department, except in a few casual allusions very late in the controversy, can the words "Monroe Doctrine" be found. 
Seward nowhere discusses his reasons for giving up the fashion of calling Monroe out of his grave whenever the United States fears European aggression; but John Bigelow wrote him in 1863 that it was desirable to avoid the phrase "Monroe Doctrine," because it was unpopular abroad. We can infer that to Seward's mind the case was so clear and unmistakable that he needed no authority from dead statesmen. He was further restrained by the uncertainties of the Civil War and the bugbear of recognition of the Confederacy. After the Trent Affair of 1861, which nearly brought about war with England, he was very unwilling to raise new questions with European governments. He adopted the diplomatic fiction that the French government could not possibly wish to dominate Mexico; and that on her side the United States would not interfere with the free choice of a government, even if it were in form an Empire. Down to the end of 1862 almost the only practical measure of the United States was to prohibit the export of arms to any other country. Not till September 21, 1863, after the battles of Gettysburg and Vicksburg, did Seward make an unmistakable protest :

"That the interests of the United States and, as it seems to us, the interest of France herself, require that a solution of the present complications in Mexico be made, as early as may be convenient, upon the basis of the unity and independence of Mexico. I can not be misinterpreting the

Independence of Mexico. sentiments of the United States in saying that they do not desire an annexation of Mexico or any part of it; . . . but they are deeply interested in the reëstablishment of unity, peace, and order in the neighboring Republic."

One of the most characteristic of Seward's numerous utterances on this subject is a dispatch of September 26, 1863:

"This government believes that foreign resistance, or attempts to control American civilization, must and will fail before the ceaseless and ever-increasing activity of material, Foreign moral, and political forces, which peculiarly belong to Control. the American continent. Nor do the United States deny that, in their opinion, their own safety and the cheerful destiny to which they aspire are intimately dependent on the continuance of free republican institutions throughout America. ... In no case are we likely to neglect such provision for our own safety as every sovereign state must always be prepared to fall back upon." 
This coolness toward the hoary and venerable doctrine of the fathers was not shared by Congress nor by a fellow member of the Cabinet. Salmon P. Chase, Secretary of the Treasury, in 1864 , wrote to a friend:

"I believe that the statesmen whose views were represented by Mr. Monroe's message - including Mr. Monroe himself -

Applicabil-

ity of

Monroe's

Doctrine. intended to be understood in the plain sense of the language employed; meant that any attempt to force the European system upon America would be dangerous to our safety, and that any interference with any American government by European powers for the purpose of oppressing it or forcibly controlling its destiny would be regarded as an unfriendly manifestation. In this sense the declaration was understood and accepted by the American people, and became a cardinal principle of American policy. After all, however, it is not so important to inquire into the history as into the soundness of the doctrine and the propriety of insisting on its application to recent events in San Domingo and Mexico.

"It certainly would have suited my temper and taste much better to do so ; and yet I cannot blame Mr. Seward for not having done so. He never renounced it; he only forebore to insist on it, when to insist would only have been counted a menace and would have precipitated reeognition of the rebel Confederacy and that recognition would have been followed by war."

To many other public men the time seemed to have come for an unmistakable protest against the French occupation in Mexico. President Lincoln held it back as long as he could, but on April 4, 1864, the House of Representatives voted by 109 to 0 that -

"The Congress of the United States are unwilling by silence to have the nations of the world under the impression that they Anti-Mon- are indifferent spectators of the deplorable events now archy. transpiring in the republic of Mexico, and that they therefore think fit to declare that it does not accord with the policy of the United States to aeknowledge any monarchical Government erected on the ruins of any republican Government in America under the auspices of any European Power."

Even this statement of an undoubted American principle was too strong for Seward, who informed the country and foreign governments that a resolution of the House of Representatives 
had no effect on the President and would not alter the policy of the Executive in Mexico.

\section{ANNEXATION PROJECTS (1865-1877)}

One reason for the withdrawal of the Spaniards from the Mexican expedition was that a desperate attempt was made by Spain to reconquer Santo Domingo. Troops were sent out in 1861 on the nominal invitation of one of the local revolutionists. The Dominicans appealed for aid to the United States, and Seward notified Spain that -

"The Government of the United States would regard with grave concern and dissatisfaction, movements in Cuba to introduce Spanish authority within the territory of Dominica."

Ignoring this protest, Spain officially re-annexed Santo Domingo. A new revolution broke out against the new government, and the United States gave notice that it would be "neutral" in this civil war. The task was too much for the resources of the Spaniards, and in 1865 they abandoned the attempt and withdrew the troops. Considering that the region involved had not been Spanish since 1795, the attack on Santo Domingo was a deliberate violation of the peace and sovereignty of the Latin-American states. The only visible reason for the failure to remonstrate was that the United States was too busy at the moment.

This indifference is the more remarkable because Seward was looking forward to the speedy annexation of Santo Domingo or of some other valuable part of the West Indies. In 1866 he sent down his son, who tried to secure Solana Bay as a naval station. In 1867 he tried to secure two little islands near Porto Rico from Spain. In 1867 he negotiated a treaty with Denmark for the cession of the islands of St. Thomas and St. John; but the Danish government, perhaps under the influence of Germany, declined to ratify the treaty. Seward's plan for annexing Santo Domingo was revived in 1869, when he made unavailing efforts to jam the proposition through Congress on a joint resolution without debate.

His successor, Secretary Fish, at once revived the negotiations, and Colonel Babcock, private secretary to President Grant, was sent down and made a treaty of annexation, which 
failed in the Senate. In vain did President Grant make this a question of state policy. In his message of May 31, 1870, he propounded an enlargement of the Monroe Doctrine in the following words :

"The doctrine promulgated by President Monroe has been adhered to by all political parties, and I now deem it proper to assert the equally important principle that hereafter no territory on this continent shall be regarded as subject of transfer to a European power."

In vain did he send a commission to Santo Domingo whose real purpose was to report that it ought to be added to the Union. When the American Civil War was over, it was hard to make people feel the military importance of a West Indian station; nor at that time could the nation be aroused to a sense of danger with regard to the Isthmus Canal.

\section{LATIN-AMERICAN WARS（1861-1869）}

In many directions the preoccupation of the United States as to the Civil War gave a chance for threats and interventions by European powers. In 1863 British ships established a temporary blockade of the Brazilian port of Rio. In 1864 Spain and Peru came into collision, and the Spaniards seized the Chincha Islands as a sort of pledge. In spite of a Congress of the South American States (except Brazil) at Lima, in November, 1864, the formal war between Chile and Spain continued till 1866. Seward tried hard to bring both sides to this unhappy conflict to an understanding and Fish succeeded in 1870 in holding a mediation conference at Washington, through which the war was ended.

In the course of the controversy the Latin-American states appealed to the United States for protection and Seward replied (June 2, 1866) that the Government would -

"Maintain and insist with all the decision and energy which are compatible with our existing neutrality that the republican system which is accepted by the people in any one of those States shall not be wantonly assailed, and that it shall not be subverted as an end of a lawful war by European powers."

In these troubles, as in those of Mexico and Santo Domingo, Seward obstinately declined to use the term "Monroe Doctrine", 
or to connect his policy with that of his predecessors in the State Department. His point of view was that what he thought advisable to do or to leave undone could be deduced from the obvious interest and wishes of the United States. Seward's views as to the position of the United States are well stated in this dispatch of June 2, 1866 :

"We then give to those republics the moral support of a sincere, liberal, and, as we think it will appear, a useful friendship. We could claim from foreign states no concession to our own political, moral, and material principles or interests, if we should not conform our own proceeding, in the needful intercourse with foreign states, to the

European

War on

Latin-

Americans. just rules of the law of nations. We therefore concede to every nation the right to make peace or war, for such causes other than political or ambitious as it thinks right and wise."

\section{WITHDRAWAL OF THE FRENCH FROM MEXICO (1865-1867)}

Upon that basis of national interest Seward proceeded to engineer the French and their Empire out of Mexico. That occupation was costly in men and money : the Empire extended only as far as the bayonets of French soldiers; and outside of that line the country was in the hands of brigands, insurrectionists, and the patriot government of Juarez. Maximilian was allied with the church party, and, though personally gallant, could not secure the affection and allegiance of the Mexicans for himself.

Seward's task of relieving the United States from these undesirable neighbors was therefore made easy, especially when in 1865 about 100,000 Union troops were sent down to the Texas frontier. General Grant supposed that his army was to cross the border and turn the French out by force. November 6,1865 , Seward instructed Bigelow, our minister in Paris, to communicate to the French Government that -

"The presence and operations of a French army in Mexico, and its maintenance of an authority there, resting upon force and not the free will of the people of Mexico, is Forcible a cause of serious concern to the United States. . . . Occupation. They still regard the effort to establish permanently a foreign and imperial Government in Mexico as disallowable and impracticable." 
Elsewhere, he says :

"We do not interfere in foreign interests or foreign politics."

February 12, 1866, Seward came to the point of demanding that the French set a time when they would withdraw. April 6, Napoleon III issued orders accordingly. He left slowly and reluctantly. Thereupon Maximilian's Empire collapsed and in spite of efforts of Seward and the American Minister to save him, he was executed. When, two years later, Seward visited Mexico, he was received with the honors of a military hero, and was made an honorary member of the National Academy of Sciences with the title of "Defender of the Liberty of the Americas."

\section{CANADA (1865-1867)}

The success of the Union in the American Civil War opened the way for Seward's effective application of the principle that foreign powers must not make conquests in the American republics. The same success led to a new spirit toward Canada. During the Civil War Confederates were received as belligerents on Canadian soil and in 1864 they organized a raid across the border into the town of St. Albans, Vermont, where they looted a bank and committed other outrages. Partly as an answer, some Irish-Americans organized a little force in June, 1866; and under the guidance of the society known as the Fenians crossed the border near the Niagara River and were speedily overwhelmed. Dislike of Canada and of Great Britain, and the rising spirit of protection, caused the United States in 1866 to put an end to the reciprocity treaty of 1854 for Canadian trade. That left the fishery rights and privileges of the United States in the northeast waters in great confusion.

All these causes combined to bring about a spirit of annexation, and at this time the home government was indifferent about Canada and would have made no serious objection if the people of that province had shown a desire for such a change of their political status. The Canadians were more loyal than had been supposed, and to prevent being picked up piecemeal formed a federal union which in 1867 was formally organized by an act of the British Parliament as the Dominion of Canada. It was difficult to deny the right of the Canadians to remain colonists if they chose, or to accept Seward's dictum that - 
"British Columbia, by whomsoever possessed, must be governed in conformity with the interests of her people, and of society upon the American continent."

In any case, the thing was done and could not be undone without war. The House of Representatives, March 27, 1867, passed the following resolution:

"The people of the United States cannot regard the proposed confederation of the provinces on the northern frontier of this country without extreme solicitude. A confeder- Canadian ation of States on this continent, extending from Monarchy. ocean to ocean, established without consulting the people of the provinces to be united, and founded upon monarchical principles, cannot be considered otherwise than as in contravention of the traditions and constantly declared principles of this government, endangering its most important interests, and tending to increase and perpetuate embarrassments already existing between the two governments immediately interested."

\section{ALASKA (1867)}

The treaty of 1824 by which the Russians accepted the southern boundary of $54^{\circ} 40^{\prime}$ proved to be a barrier to genuine Russian colonization. Numerous posts were planted farther south, but all of them on other people's territory; and the Alaskan coast was rocky and inhospitable. After nearly a century of occupation there were only a few hundred Russians in the province; hence the government back in the fifties had been willing to give it up. In 1867 it was offered to Seward, who within twelve hours came to an agreement, and the treaty was ratified the same year.

Considering the failure of all Seward's schemes in the West Indies, this was a soothing triumph. It removed one of the European powers entirely from the western continent; it gave a new hold on the Pacific Ocean and Pacific trade; and the region proved to have a wealth of sea life and of minerals which made its purchase for $\$ 7,200,000$ a good bargain. Seward once stated in conversation that he bought Alaska lest England should acquire it in order to strengthen touch with British Columbia, and possibly pave the way for its annexation by Canada. Perhaps a stronger motive was to extend American territory toward Asia, in accordance with his speech in the 
Senate in 1858. Sumner who liked to say things that might startle his hearers, remarked of the Alaska purchase that "we dismiss one other monarch from the continent."

\section{PREPARING THE WAY FOR A CANAL (1864-1869)}

Since no steps were taken to construct a canal under the Clayton-Bulwer Treaty, public interest lagged; but not the interest of Seward, who made four different efforts to bring the United States into relations of special advantage with the Central-American powers. The first of these was a treaty negotiated with Honduras in 1864 which much resembled the Colombian Treaty of 1846 . The Honduras government agreed to keep open any canal or road that might be constructed across its territory, and on the other side the United States guaranteed -

"In consideration of these concessions, in order to secure the construction and permanence of the route or road herein contemplated, and also to secure, for the benefit of manGuaranty of a Road across Honduras. kind, the uninterrupted advantages of such communication from sea to sea, the United States recognizes the rights of sovereignty and property of Honduras in and over the line of said road, and for the same reason guarantees, positively and efficaciously, the entire neutrality of the same, so long as the United States shall enjoy the privileges conceded to it in the preceding section of this article. And when the proposed road shall have been completed, the United States equally engages, in conjunction with Honduras, to protect the same from interruption, seizure, or unjust confiscation, from whatsoever quarter the attempt may proceed."

This treaty was duly ratified, but since no route was ever built through Honduras, it was not executed. It was one link in a chain of treaties, covering all the Isthmus routes.

In 1866 Seward made an unsuccessful move on the west coast, which had been a subject of controversy in 1849 . He wrote to Adams in London, setting forth certain needs of territory on the Pacific Coast, especially at Tigre Island:

"It is indispensable for us . . to have coaling stations under our own flag for naval observation and police, and for defensive war Coaling as well as for the protection of our widely-spread comStations. merce when we are at peace ourselves. This want, 
even for our commercial marine, is nowhere more sensibly felt than on the track between Panama and San Francisco. . . . Whatever opinion might be entertained in regard to any other sites, there would be no question that Tigre Island would be exceedingly desirable for that purpose. . . . You will sound Lord Clarendon as to the disposition of his Government to favor us in acquiring coaling stations in Central America, notwithstanding the stipulation contained in the Clayton-Bulwer treaty. In doing this, however, you will use general terms only, and will by no means allow it to be supposed that we particularly covet Tigre Island."

Nothing came of this suggestion; but in 1867 Seward made his third move by negotiating what is commonly called the Dickinson-Ayon Treaty with Nicaragua, ratified in 1868. As in the other similar treaties, the United States pledged herself to protect the construction of the canal on that side.

"The right of transit between the Atlantic and Pacific Oceans through the territory of that Republic, on any route of communication, natural or artificial, whether by land or by water, which may now or hereafter exist or be constructed under the authority of Nicaragua. . . . The United States hereby agree to extend their protection

Guaranty of Transit across Nicaragua. to all such routes of communication as aforesaid, and to guarantee the neutrality and innocent use of the same. They also agree to employ their influence with other nations to induce them to guarantee such neutrality and protection."

The fourth measure was a treaty negotiated with Colombia to supersede the treaty of 1846 . It was submitted in 1867, amended, agreed to by the executives of both governments early in 1869 , but failed in the Senate. The treaty would have granted to the United States the sole right to a ship canal across the Isthmus of Panama, and set apart for that purpose a canal strip twenty miles wide. The United States government, or a company chartered by the United States, was to construct the canal and control it. Yet the treaty in the last resort left the ownership to Colombia:

"The United States of Colombia shall retain their political sovereignty and jurisdiction over the canal and territory appertaining thereto; but they shall not only allow but guarantee to the United States of America, according to the constitution and laws of Colombia, now in force, the 
peaceable enjoyment, control, direction, and management of the same, as before specified."

The significance of these almost forgotten treaties and suggestions for treaties is that they assumed that the United States had an interest in the Canal, which was superior to that of any other country, and which ought to exclude all other countries. Not one of the documents can be reconciled with the intention of the Clayton-Bulwer Treaty, which was that the responsibility for a canal should be divided at least between the United States and Great Britain. The passing of nearly twenty years after the negotiation of that treaty, without any progress in construction, was a disappointment; and the conviction that the only way to secure a Canal was for the United States to undertake it solely, is evidence of a new spirit toward the whole enterprise.

\section{THE JOHNSON DOCTRINE (1868)}

President Johnson had been carried along by Seward's activity like a passenger on a ship. In his last annual message in 1868, he broke loose with an amazing proposition that the remedy for all the internal difficulties of the Latin-American States would be-

"While the United States have on all occasions professed a decided unwillingness that any part of this continent or of its adjaAnnexation cent islands shall be made a theater for a new estabof all Neighboring done by us, on the other hand, to attach the comAmerica. munities by which we are surrounded to our own country, or to lend even a moral support to the efforts which are so resolutely and so constantly making to secure republican institutions for themselves. . . C Comprehensive national policy would seem to sanction the acquisition and incorporation into our Federal Union of the several adjacent continental and insular communities as speedily as it can be done peacefully, lawfully, and without any violation of national justice, faith, or honor. Foreign possession or control of those communities has hithereto hindered the growth and impaired the influence of the United States. ... The conviction is rapidly gaining ground in the American mind that with the increased facilities for intercommunication between all portions of the earth the principles of free government, as embraced in our Con- 
stitution, if faithfully maintained and carried out, would prove of sufficient strength and breadth to comprehend within their sphere and influence the civilized nations of the world."

This extraordinary proposition needs no comment. It may have been suggested by Seward, but it was out of all relation with public sentiment, and fell little heeded.

\section{RESULTS OF SEWARD'S DIPLOMACY (1861-1869)}

A brief review of the eight years of Seward's service as Secretary of State may bring out the general success of his American policy. Backed up by circumstances and the United States army, he was able to squeeze the French out of Mexico without hostilities either with Mexico or France. The Spaniards withdrew from Santo Domingo without even a show of protest. He annexed Alaska, and was prevented only by what seemed an accident from the statesmanlike project of purchasing the Danish Islands. He failed in his great designs on Canada and his open attempts on Santo Domingo. His Canal diplomacy struck out a new path and he attempted to ignore the relation of Great Britain to the whole Canal scheme.

What stands out in the whole history of this period is that the Monroe Doctrine of Secretary Cass and the Monroeless Doctrine of Secretary Seward led to exactly the same point; viz., that the Latin-American countries were made up of people who did not know how to govern themselves and who kept the neighborhood of the United States stirred up with misrule and anarchy. Therefore - so ran relentlessly the logic of both Secretaries - the remedy was for the United States to annex these lawless and ungovernable regions. That comes out clearly in the utterances of all the Presidents (except Lincoln) from Polk to Johnson. Not one of them was really concerned with the duty of protecting Europeans or of avoiding difficulties with Europe. They all rested their case on the needs of the United States - sometimes the need of markets, sometimes of slave-holding territory, sometimes of peace and quiet. The more populous the neighboring nations grew, the more complicated their relations with each other and the world became, so much the more necessary it seemed to those statesmen to "take arms against a sea of troubles, and by opposing end them." 



\section{PART III \\ THE AMERICAN DOCTRINE \\ 1869-1915 \\ Chapter XI \\ DOCTRINE OF PARAMOUNT INTEREST \\ 1869-1884 \\ CHANGE OF EMPHASIS}

From 1845 to 1869 the usual theory of the government and people of the United States was that a principle had been laid down by President Monroe, which was broad enough and prophetic enough to cover any and all phases of our relations with Latin America. Every President, except Lincoln, and every Secretary of State, except Seward, referred back in terms or indirectly to Monroe. Several of them quoted him and professed to expand and improve him. Even Lincoln and Seward followed the traditional lines of Monrovian policy. The interests which they had in mind were chiefly political influences, - international friendships, and then territorial. The fundamental idea of them all was that Monroe had expressed a classic and hallowed form of international philosophy, which justified some kind of action on the part of the United States government in favor of Latin-American powers that were in trouble with European powers.

Since 1869, the prevailing thought among statesmen has been more individual. They have referred to the tradition, but have relied on a strong and definite line of policy, which was to be stated from time to time not for the benefit of others, but because it was needed in the interests and for the welfare of the United States. They were willing to add as a plausible argument that such a policy was also in accord with previous statements and acts put forth by Monroe and his successors. 
The incidents and controversies which involved special interests of the United States were still mostly political ; but strong commercial influence began to be felt, especially in the Caribbean area.

A new sense of commercial potency animated our statesmen. The Cuban question was largely one of trade. The Isthmus controversy was chiefly over the desire to get into line for control of a world-waterway. The brief phrase which best expresses this altered point of view is Secretary Evarts' "Paramount Interest." Journalists, writers, and public men have generally found it more convenient to keep on using the old term "Monroe Doctrine", both because it was hazy and because it seemed to make earlier generations responsible for the purposes and motives of the present time. To the changed and broadened principle will be usually applied in the remainder of this volume the term "American Doctrine."

\section{THREE SECRETARIES OF STATE (1869-1882)}

The difficult problems of American policy were taken up after 1869 by three successive Presidents, of whom two - Grant and Hayes - took a direct and personal interest in PanAmerican affairs. The handling of most of the specific questions and the phrasing of most of the important documents was left to three remarkable Secretaries of State: Hamilton Fish, William M. Evarts, and James G. Blaine. Though only one of them had previous diplomatic experience, Fish became one of the most efficient heads of the American foreign office; Evarts was a profound lawyer, who carried his principles into public law; Blaine, though a politician and an advocate, showed a more definite theory, larger views, and a more attractive program than either of his predecessors.

All three Secretaries had to contend from first to last against an apathy in public opinion. Apparently most members of Congress and their constituents preferred to keep out of any kind of pledges or agreements with American powers, looking to political action. It was the fashion at that time to believe that the annexations of Texas and the Mexican War were wholly due to the greed of the slave power; and that the immediate task of the United States was to undo the evils which had come on the country. Public interest, therefore, was 
directed first to the task of reëstablishing the South, the settlement of the West, and the reconstitution of the nation. The completion of the first Pacific railroad in 1869 at once took away much of the importance of the Isthmus routes, which for many years thereafter were little used, either for freight or passengers. Mexico was unexpectedly brought out of the anarchy of half a century, first by Juarez and then by the remarkably able and unscrupulous dictator, Diaz. American capital, mines, and railroads were encouraged and safeguarded in that country, and for a long time the cry for annexation of Mexico ceased. The two West Indian republics of Haiti and Santo Domingo, though at last recognized by the United States, were not in a condition which made them desirable wards.

\section{THE GRANT DOCTRINE AND CUBA (1866-1870)}

In this hurly-burly of plans and complications, the one serious and dangerous Latin-American question was that of Cuba. The Spanish government was probably no more harsh than in earlier periods. Many of the richest and most influential men were born Spaniards; and most of the native planters and large business men were favored by the Spanish government and had no desire for independence. Nevertheless, in 1866 an insurrection broke out, which was the first approach to a spontaneous movement for Cuban independence. During the next seven years Spain in Europe passed through four revolutions, and could give little attention to distant colonies. The cause of revolution was aided by a Junta of native Cubans, living in the United States, who organized a score of filibustering expeditions during the progress of the revolution.

Great sympathy was felt with the Cubans by the United States ; and in 1869 Grant was on the point of recognizing their belligerency; but he took the advice of Secretary Fish and held back. He began at once to appeal to his countrymen in behalf of the Latin-Americans. In his first annual message (1869), he said :

"These dependencies are no longer regarded as subject to transfer from one European power to another. When the present relation of colonies ceases, they are to become independent powers, exercising the right of choice and of self-control in the determination of their future condition and relations with other powers." 
May 31, 1870, in a message on the annexation of Santo Domingo, he laid down a principle as to the American colonies of European powers, which he apparently supposed to be novel:

"The doctrine promulgated by President Monroe has been adNon-trans- hered to by all political parties, and I now deem it fer of proper to assert the equally important principle that European hereafter no territory on this continent shall be colonies. regarded as subject of transfer to a European power. . . . The acquisition of San Domingo is an adherence to the 'Monroe doctrine." "

A few days later (June 13) he returned to the question, summarized the history of the Monroe Doctrine and laid down his own principles as follows:

"The strict adherence to this rule of public policy has been one of the highest honors of American statesmanship, and has secured

Prominence and Influence of the United States. to this Government the confidence of the feeble powers on this continent, which induces them to rely upon its friendship and absence of designs of conquest and to look to the United States for example and moral protection. It has given to this Government a position of prominence and of influence which it should not abdicate, but which imposes upon it the most delicate duties of right and of honor regarding American questions, whether those questions affect emancipated colonies or colonies still subject to European dominion."

A year later (April 5, 1871), he announced another principle as follows :

"I believed ... that our institutions were broad enough to extend over the entire continent as rapidly as other peoples might desire to bring themselves under our protection. I Annexation believed further that we should not permit any inby the United States within the Monroe Doctrine. dependent government within the limits of North America to pass from a condition of independence to one of ownership or protection under a European power. . . . In view of the facts which had been laid before me, and with an earnest desire to maintain the 'Monroe doctrine', I believed that I would be derelict in my duty if I did not take measures to ascertain the exact wish of the Government and inhabitants of the Republic of San Domingo in regard to annexation and communicate the information to the people of the United States." 
Except for the sentences which bear on the voluntary cession of a Latin-American State to an European State, these messages are vague. Did President Grant feel the need of restoring Monroe to his old position of patron internationalsaint to the United States? Did he wish to put himself on an equality with Polk and Buchanan by framing a new doctrine? Or was he simply trying to remove the objections to the annexation of Santo Domingo by arguing that it was just the sort of thing that Monroe would have done? Whatever Grant meant, it more closely approximated the American Doctrine than the Monroe Doctrine.

\section{THE FISH DOCTRINE (1870)}

Undoubtedly Secretary Fish furnished the President the argument and probably most of the text of these messages. July 14, 1870 , in answer to an inquiry by Congress as to why the United States received so little of the Latin-American trade, Fish sent in a long-winded report on the general relations of the United States to Latin America since 1810, in which he discussed the questions 'of "entangling political alliances", “independent neutrality", "non-interference", "recognition of the Holy Alliance", and "The Monroe Doctrine." He lamented the fact that the United States had not in 1826 seized -

"the opportunity of giving a permanent direction to the political and commercial connections of the newly enfranchised Spanish American states."

From these historical considerations, Fish elsewhere advances to a statement of the place of the United States in America, which is quite outside of the old Monroe doctrine :

"The United States . . o occupy of necessity a prominent position on this continent which they neither can nor should abdicate, which entitles them to a leading voice, and which imposes upon them the duties of right and of honor regarding American questions, whether those questions affect emancipated colonies, or colonies still subject to

Leading

Voice in

North

America. European dominion."

Fish ends in an invitation to Latin America to place itself under the beneficent direction of the United States. 
"A favorable time has now come for . . . laying the foundation of an American policy which shall bind in closer union the American Joint Policy. American republics. Let them understand that the United States do not covet their territories. . . . Let them feel that, as in 1826 , so now, this government is ready to aid them to the full extent of its constitutional power in any steps which they may take for their better protection against anarchy. Let them be convinced that the United States is prepared, in good faith and without ulterior purposes, to join them in the development of a peaceful American commercial policy, that may in time include this continent and the West Indian Islands."

Fish's American Doctrine goes far beyond Grant's expressions, and outstrips most of the announcements of previous Secretaries of State. He is the first Secretary of State to frame a policy of All-North-America in political, and especially in international matters. His main thought is that a development of American commerce would be likely to bring peace and stability to other American powers. The United States at this period was reaching out to the Orient with steam lines from California. Commerce with Europe was also stimulating the building of new ships and the formation of the great foreign steamer lines which have since done so much to enlarge and cheapen the exchange of American products against Europeans and Asiatics.

Up to this time, there is little trace of a conscious effort by diplomacy to aid American manufacturers or shippers, in gaining the Latin-American market. Fish foresaw the advantages which McKinley later realized, and he also desired the footing in the West Indies which Roosevelt gained. His part in the development of an American Doctrine deserves more respect than was accorded it then or since.

\section{SETTLEMENT OF THE CUBAN QUESTION (1869-1878)}

When Fish sought to apply his American commercial doctrine to Cuba, it did not fit, though part of the ground of controversy with Spain was the business interest of Americans in Cuba, who suffered both from misgovernment and from the disturbance of the war. The prime issue was the right of a European power to engage in battle with a daughter colony in America. The interest of the United States government 
was also aroused because American citizens were often arrested, especially American citizens of Cuban birth who had become naturalized in the United States in order to escape from the control of their native government. From these and other Spanish measures a thriving crop of claims arose, the bill for which was eventually brought to the Spanish government. In 1873 the Spaniards captured the filibustering ship, Virginius, and without further ceremony shot a number of American citizens who were on board. Nothing but General Grant's unwillingness to go to war prevented hostilities with Spain upon this issue.

As the Cuban war drifted on year after year without definite results, Secretary Fish thought out a new method of putting an end to the controversy. This was to turn his back on everything that went by the name of Monroe Doctrine, by summoning the principal European powers to a joint intervention. November 5,1875 , he proposed through our minister in Spain a scheme which had some of the elements of the Holy Alliance that so alarmed Rush, Monroe, and John Quincy Adams in 1823.

"In the absence of any prospect of a termination of the war, or of any change in the manner in which it has been conducted on either side, he feels that the time is at hand when it may be the duty of other Governments to intervene, solely with a view of bringing to an end a disastrous and destructive conflict, and of restoring peace in the island of Cuba. ... This conclusion is reached with

Joint

European and American Intervention. reluctance and regret. It is reached after every other expedient has been attempted and proved a failure, and in the firm conviction that the period has at last arrived when no other course remains for this Government."

This was a doubtful remedy, because if it failed, war could hardly be prevented between the United States and Spain. Germany, Russia, and Italy expressed a willingness to take part. Austria, France, and England hesitated. Spain, however, took warning, dealt directly with the United States, and promised such reforms in Cuba as would put an end to the revolution. This promise was carried out in 1878. Though Fish's proposition was well known both in Europe and America, it was more than twenty years before the correspondence was all made public. The Secretary had carried his point by threatening a course of action which would perhaps in the end have led 
to the establishment of a kind of international board to pass upon the relations of Spain and her colonies.

\section{FISH'S CANAL DIPLOMACY (1869-1875)}

As soon as Fish came into office he took up the question of Isthmian diplomacy, and negotiated with Colombia for an agreement which would carry out the main lines of Seward's policy. He thus claimed sole American control-

"The proposal of a protectorate over the canal, in which other maritime powers should be joined with the United States in equal

No Joint

Canal Protectorate. control, would probably remove many of the obstacles to the attainment of the grant, and may secure the ratification of a treaty by the Colombian Government.

But in the present state of international law, such joint protectorate would be the source of future trouble, and, while it might facilitate the concession by the Colombian Government, would be viewed with apprehension in the country, and might probably prove an obstacle to the ratification by the United States Senate of a treaty on the subject. Apart, however, from the latter consideration of expediency, the President is disinclined to enter into any entanglement in participation of control over the work with other powers. He regards it as an American enterprise, which he desires to be undertaken under American auspices, to the benefit of which the whole commercial world should be fully admitted."

A treaty was accordingly signed, January 6,1870 , in which the Colombians offered rather less favorable terms than the unsuccessful convention of the year before. Even with that concession the Colombian Senate finally declined to ratify it, upon technical grounds. The United States government thereupon provided for surveys of the Isthmus by an Inter-Oceanic Canal Commission, which in 1875 reported in favor of the Nicaragua route.

Fish was perfectly aware that he was acting outside the limitations of the Clayton-Bulwer Treaty. Though he objected to a renewal of the British claim to the Mosquito Coast, he made no protest against that treaty and did not intimate that it was out of force. Notwithstanding his claim of sole control, his correspondence shows that he was not averse to some sort of international understanding, or even a commission, which should take over the whole Isthmian question, and supervise a canal. 


\section{EVARTS AND HAYES DOCTRINES}

Toward the end of Grant's second administration a change came about in the Isthmus question, and consequently in the relations with all Latin America. In 1869 a canal was completed across the Isthmus of Suez by French capital, directed by the French engineer, De Lesseps. This successful enterprise gave new strength to the demand for a similar canal across the American Isthmus. De Lesseps seems to have hoped to secure concessions both from Nicaragua and Colombia; but settled down on one obtained by one Wyse from the Colombian government in 1878. A French company formed in 1879 bought Wyse's concession and set out to construct the canal. In 1879 a scientific congress was called by De Lesseps in Paris, which, by rather sharp practice, was brought to the point of recommending the Panama route as the most practical. In 1881 engineers of the new company appeared on the line of the proposed canal, and in 1883 construction began.

This presented the new issue whether the United States would consider it contrary to national interest or to the American Doctrine, for a single European power to authorize the construction of a canal over the route covered by the Colombian Treaty of 1846 and by the Clayton-Bulwer Treaty of 1850 . The French plan was also contrary to the efforts of Seward and Fish in 1864 and 1870 to secure a specially favored status on the Isthmus for the United States.

De Lesseps settled that question offhand in the North American Review:

"The Monroe doctrine, so far from being opposed to our enterprise, is directly favorable to it; inasmuch as it is the Republic of the United States of Colombia which has granted the concession for the Panama Canal, and the decree of the President of the United States of Colombia, of the 3d of September, 1879, as well as the letter of the Governor of Panama, which informed me of that decree, very plainly signify that the nations of that part of America are heartily enlisted in the undertaking."

Some members of the House were sufficiently aroused to propose that steps be taken to abrogate the Clayton-Bulwer Treaty. The President and Secretary of State decided that the time had come for a review of the whole subject and a restatement of the principles of American relations. Secretary 
Evarts' views were stated in an elaborate report of March 8, 1880, of which the most significant clauses are the following:

"The United States has constantly and earnestly desired to stimulate and assist these States in the opening of such routes of comAid by the merce through their respective territories. The treaties U.S.to a that have been made with these States, as well as Canal. those more vigorous and efficient ones which have been attempted but have failed of consummation, have all shown a fixed policy of this government to corroborate the inadequate resources of these States by the security to capital and to commerce which the effective guaranty of the power and faith of this country, in support of these routes, was calculated to give.

"The purpose of this government that the benefits of the routes to be opened should be shared upon equal terms and with equal seEqual Use. curity, by the commerce of the world, has been equally evident and uniform. Its own relations to the enterprises projected have never been pressed beyond the measure of control commensurate with the responsibilities and burdens which the recognized exigencies of the situation required it to assume.

"The paramount interest of the United States in these projects of interoceanic communication across the American isthmus has

\section{Paramount} Interest of the U. S. seemed quite as indisputable to the European powers as to the States of this continent. The course of their action and correspondence, so far as they have treated the subject, exhibits a clear appreciation of the public and general motives which had marked, and might be trusted to continue to mark, any dealing by this government with these great interests of commerce and civilization in the Western hemisphere. Accordingly they have shown no disposition to take part in any political arrangements of this American question, except in accord with the United States, and upon an evident desire of this government that they should do so."

President Hayes followed up this report with a formal message, which embodied very advanced views as to the rights of the United States against all the other powers:

"The policy of this country is a canal under American control. The United States can not consent to the surrender of this control to any European power, or to any combination of American Control of a Canal. European powers. If existing treaties between the United States and other nations, or if the rights of sovereignty or property of other nations stand in the way of this policy - a contingency which is not apprehended - 
suitable steps should be taken by just and liberal negotiations to promote and establish the American policy on this subject, consistently with the rights of the nations to be affected by it.

"The capital invested by corporations or citizens of other countries in such an enterprise must, in a great degree, look for protection to one or more of the great powers of the world. No European power can intervene for such protection of Capital. without adopting measures on this continent which the United States would deem wholly inadmissible. If the protection of the United States is relied upon, the United States must exercise such control as will enable this country to protect its national interests and maintain the rights of those whose private capital is embarked in the work.

"An interoceanic canal across the American Isthmus will essentially change the geographical relations between the Atlantic and Pacific coasts of the United States, and between the United States and the rest of the world. It will be the great ocean thoroughfare between our Atlantic

Coast line of the U. S. and our Pacific shores, and virtually a part of the coast line of the United States. Our merely commercial interest in it is greater than that of all other countries, while its relations to our power and prosperity as a nation, to our means of defense, our unity, peace, and safety are matters of paramount concern to the people of the United States. No other great powers would, under similar circumstances, fail to assert a rightful control over a work so closely and vitally affecting its interest and welfare."

In these two documents a new policy and two new phrases - "paramount interest" and "coast line of the United States" - are put forward with great clearness. The immediate purpose of both the President and the Secretary was to concentrate public opinion against the construction of the canal by a French company. In addition, they meant to lay down a distinct doctrine, which should lead the country into a new path. In both directions the result was disappointing. They aroused only some discussion in Congress and a moderate amount of attention in the newspapers; then the country fell back into the old apathy. The accounts of the French Canal Company, when made public some years later, showed large sums spent in the United States for affecting the public mind. Nevertheless, the real reason for this seeming indifference seems to have been that nobody felt any fear of a company which had no rights except a private concession granted by Colombia; which 
must leave within the bounds of that Republic whatever work it might do ; and which very likely would never finish the canal. If the French investing public was willing to spend its money on a work for which no American capital was forthcoming, the American people were willing that they should spend it; and felt competent to protect their country's special interest whenever a crisis came.

\section{THE BLAINE DOCTRINE (1881)}

When President Garfield succeeded President Hayes, in March, 1881, he made James G. Blaine his Secretary of State, in which office Blaine remained only a few months after the death of Garfield. Secretary Blaine was an ardent and impulsive man who much resembled Henry Clay in character and career. He shared in the feeling that the United States ought not to leave the future of the canal to the chance success or failure of a French venture. In his inaugural address President Garfield repeated Hayes' assertion of the -

"Right and duty of the United States to assert and maintain such supervision and authority over any interoceanic canal across the isthmus . . . as will protect our national interests."

Fortified by the President's support, the Secretary began to prepare material for a trumpet blast upon the whole subject; and on June 24, 1881, he sent out a circular dispatch upon the relation of European powers to the construction and neutrality of the canal, of which the most important passages are as follows :

"The great powers of Europe may possibly be considering the Guaranty subject of jointly guaranteeing the neutrality of the of Neutral- interoceanic canal now projected across the Isthmus ity. of Panama.

"The United States recognizes a proper guarantee of neutrality as essential. ... The necessity was foreseen and abundantly provided for, long in advance of any possible call for the actual exercise of power. In 1846 a memorable and important treaty was negotiated and signed between the United States of America and the Republic of New Granada, now the United States of Columbia. ... In the judgment of the President this guarantee, given by the United States of America, does not require reenforcement, or accession, or assent from any other power. . . . 
"It is as regards the political control of such a canal, as distinguished from its merely administrative or commercial regulation, that the President feels called upon to speak with Political directness and with emphasis. During any war to Control. which the United States of America or the United States of Colombia might be a party, the passage of armed vessels of a hostile nation through the canal of Panama would be no more admissible than would the passage of the armed forces of a hostile nation over the railway lines joining the Atlantic and Pacific shores of the United States or of Colombia. ... .

"An agreement between the European states to jointly guarantee the neutrality and in effect control the political character of a highway of commerce, remote from them and near to us, No Joint forming substantially a part of our coast-line and Guaranty. promising to become the chief means of transportation between our Atlantic and Pacific States, would be viewed by this government with the gravest concern. . . . Any attempt to supersede that guarantee by an agreement between European powers, which maintain vast armies and patrol the sea with immense fleets, and whose interest in the canal and its operations can never be so vital and supreme as ours, would partake of the nature of an alliance against the United States, and would be regarded by this government as an indication of unfriendly feeling. . . .

"It is the long-settled conviction of this government that any extension to our shores of the political system by which the great powers have controlled and determined events in Europe would be attended with danger to the peace and welfare of this nation. ... It is nothing more

Political System of Europe. than the pronounced adherence of the United States to principles long since enunciated by the highest authority of the government, and now, in the judgment of the President, firmly inwoven as an integral and important part of our national policy."

Blaine was completely convinced by his own logic; in fact he was only stating what twenty years later became the accepted and successful policy of the government. It was however, a clumsy misjudgment to leave out of a dispatch which was to be communicated to the English government, all allusion to the Clayton-Bulwer Treaty ; for he thus gave an opportunity to Earl Granville, British Foreign Minister, to recall his wandering attention to that point. In later dispatches of November 19 and November 21, 1881, Blaine set himself to the task of showing that the treaty had lapsed, partly by change of circumstances and partly because Great Britain had not 
observed it. One passage in these dispatches is of great significance, as showing an advance in the conception of LatinAmerican relations, which might justify elbowing Great Britain out of her position of joint interest; it is also the first public statement of the meaning of the Suez Canal to America :

"The military power of the United States, as shown by the recent civil war, is without limit, and in any conflict on the American conRights of tinent altogether irresistible. The Clayton-Bulwer Defense. treaty commands this government not to use a single regiment of troops to protect its interests in connection with the interoceanic canal, but to surrender the transit to the guardianship and control of the British navy.... Its provisions embody a misconception of the relative positions of Great Britain and the United States with respect to the interests of each government in questions pertaining to this continent.

"The United States seeks only to use for the defense of its own interests the same forecast and provision which Her Majesty's Government so emphatically employs in defense of the interests of the British Empire. . . . She holds a controlling interest in the Suez Canal, and by her fortifications at Aden and on the island Suez Canal of Perim she excludes all other powers from the as an Example. waters of the Red Sea and renders it a mare clausum. It would, in the judgment of the President, be no more unreasonable for the United States to demand a share in these fortifications, or to demand their absolute neutralization, than for England to make the same demand in perpetuity from the United States with respect to the transit across the American continent. . . .

Sole Control of the Canal by the U.S.

in any and every event, to enforce the guardianship which she shall assume."

\section{POSTPONEMENT OF THE BLAINE DOCTRINE (1882-1885)}

The attitude of Great Britain was stated with almost insulting courtesy by Lord Granville, January 7, 1882 :

"The declarations of President Monroe and of his cabinet, in 1823 , and 1824 , whatever may be the view taken of their scope and bearing, and of the admissibility of the principles which they 
involve, or which it is sought to deduce from them, show at least that at that period - twenty-six years anterior to the treaty now under discussion - there was a clear prevision of the great future reserved to the Pacific coast. It is, in the opinion of Her Majesty's Government, an inadmissible

Bearing of Monroe's Doctrine. contention that the regular and successful operation of causes so evident at the time, and in their nature so irrepressible, should be held to have completely altered the condition of affairs. . . .

"Her Majesty's Government would be wanting in regard to their duty if they failed to point out that Great Britain has large colonial possessions, no less than great commercial interests, which render any means of unobstructed and rapid access from the Atlantic to the North and South

British

Concern in a Canal. Pacific Oceans a matter for her also of the greatest importance. .. . They are of opinion that such a canal, as the waterway between two great oceans and between all Europe and Eastern Asia, is a work which concerns not merely the United States or the American Continent, but the whole civilized world."

However logical this position, it did not dispose of the fact that the canal was vastly more important to the United States than to Great Britain; nor of the other fact that Great Britain was on the way to absolute mastery over the Suez Canal. Ever since 1875 the British government had controlled the majority of the stock; in 1882 the British landed troops in Egypt, and in 1883 took possession of that country. By her private ownership of the Canal, and her public control of the region through which it ran, Great Britain became practically the sole governmental force in the Isthmus of Suez. It was announced that England remained in Egypt only to keep order for a time; and that the Canal would be opened to the neutral use of all nations. In 1888 the Convention of Constantinople was drawn up, laying down elaborate rules for the management and neutral use of the Canal. All this did not in the least affect the fact that Great Britain remained in possession and control of one of the two great Isthmus routes of the world; and at the same time continued to claim under the ClaytonBulwer Treaty a joint interest in the other world-Isthmus route. That gave to Great Britain one and a half canals, against one-half for the United States. No argument could upset the mathematics of this proposition; in the long run, England must withdraw from the degree of control which a half-share in America would give. 
Blaine continued to argue against the treaty, against Great Britain, and against foreign participation in the Canal ; and his successor, Frelinghuysen, kept up this war of words and he restated the argument against joint control of the Canal.

"The President believes that the formation of a protectorate by European nations over the isthmus transit would be in conProtectorate flict with a doctrine which has been for many years of the Canal. asserted by the United States. This sentiment is properly termed a doctrine, as it has no prescribed sanction and its assertion is left to the exigency which may invoke it. It has been repeatedly announced by the Executive Department of this government and through the utterances of distinguished citizens; it is cherished by the American people, and has been approved by the Government of Great Britain."

Near the end of Arthur's administration Frelinghuysen negotiated (1884) a convention with Zavala in behalf of Nicaragua, by which the United States was to enter into "perpetual alliance", with Nicaragua, and to be allowed to build a canal through that country. This action was intended to be a defiance of Great Britain, for the Clayton-Bulwer Treaty was framed first of all with reference to the Nicaragua route. The Senate never ratified the treaty and Arthur's administration closed without any advance in settling the issue. Meantime, the French were hard at work on their canal and De Lesseps was promising speedy completion.

When Venezuela came into controversy with Great Britain over the boundaries of British Guiana and appealed to the United States to interpose in behalf of the Monroe Doctrine, Frelinghuysen replied :

"The moral position of the United States in these matters was well known through the enunciation of the Monroe doctrine, but formal action in the direction of applying that doctrine to a speculative case affecting Venezuela seemed to be inopportune, and I could not advise Venezuela to arouse a discussion of the point."

\section{HEGEMONY IN AMERICA (1881-1885)}

Blaine's contest over the Clayton-Bulwer Treaty was only a part of a general plan for larger influence in Latin America. As Secretary of State, Clay had a prophetic vision of the United 
States as a sun among planets. Most statesmen who had anything to do with Latin-American affairs, especially the diplomatic representatives of the United States, felt the misery and wastefulness of the civil and public wars. Central America, North and South America, the west coast of South America, and the La Plata region were all centres of quarrels, boundary struggles, and wars. A few of the most difficult boundary controversies were settled by arbitration, such as the dispute between Argentina and Paraguay, which the President of the United States as arbiter decided in 1878.

The United States followed with strictness her policy of standing neutral in all these struggles. She was herself engaged in quarrels with several of the minor Latin powers over the claims which were always accumulating. Some of these difficulties were arbitrated. But in 1875 an arbitral commission made such findings in favor of American claimants against Venezuela that that country protested, and, after ten years' effort, the arbitration was re-opened and the United States owned that fraudulent claims had been allowed. Such a failure of justice was certain to prejudice all the Latin-American countries against any effort of the United States to act as an impartial friend.

The old idea of improving the conditions of America by a joint understanding through a Latin-American, or possibly Pan-American Congress, started up again in 1877, when a congress of jurists of Latin America met at Lima and drew up uniform rules of private international law. In 1880 Chile and Colombia formed an arbitration treaty, and in 1881 an attempt was made to hold a general arbitration conference of Latin America. Blaine nursed the idea of leading such a Congress and (November 29, 1881) sent out invitations to all the independent countries of North and South America to send delegates to Washington a year later. The one purpose of the congress was announced to be, to find some way of preventing war.

These plans were a revival of the ambitions of John Quincy Adams and Seward. They rested on the natural feeling that the greatest of the American republics should be interested in all the others; and should take a leading part in every movement for strength and stability in America. Blaine's hope was to aid in bringing about peace, so as to give a vantage 
ground for schemes of trade, commerce, and possibly a PanAmerican alliance. He was an ambitious man who hoped for the advantage of his country; but he saw that advantage in an American policy which would help all parties. The whole plan was doubtless in his own mind interwoven with the purpose of pushing Great Britain out of her position on the Isthmus.

\section{INTERVENTION IN SOUTH AMERICA (1881-1883)}

An opportunity to put into effect the principles of peace was ready to hand ; for in 1879 Chile declared war on Peru and Bolivia. There were old quarrels and boundary squabbles, but the main object of the war was to seize the immense nitrate beds along the west coast of South America, which had come to have an enormous commercial value. The Chileans captured the nitrate beds, eventually took Lima, seized and took away the pictures and other works of art; and held the country, waiting for some Peruvian government to be formed which would be willing to make very unfavorable terms of peace. The notion of American intervention was afloat in diplomatic circles during Evarts' administration of the State Department: for three different ministers in South America took it on themselves without instruction to offer the mediation of their country. One was censured and another removed in consequence. When Blaine assumed office, the Peruvians were already defeated and Minister Christiancy wrote home from Peru, advising his government that -

"The great mass of all classes of Peruvians feel a very strong attachment for the United States and a bitter hatred to England. ... I I would not advise the United States ... to take any stock in any of the South American republics unless she can take the controlling stock. This they could easily have in Peru, if they choose to take it."

Christiancy was replaced by General Hurlbut, a personal friend of President Grant, who was instructed by Blaine to urge moderation on the conquerors. The farthest point that the instructions reached in the direction of intervention was expressed in two sentences:

"The government of Peru may fairly claim the opportunity to make propositions of indemnity and guarantee before submitting 
to a cession of territory. As far as the influence of the United States will go in Chili, it will be exerted to induce the Chilian Government to consent that the question of the cession of territory should be the subject of

Avoidance of Territorial Cessions. negotiation and not the condition precedent upon which alone negotiation shall commence."

Hurlbut took it upon himself without further instructions to serve a different notice on the Chilean government, saying that the United States is -

"Very clearly of the opinion that Peru ought to have the opportunity, in full and free discussion of the terms of peace, to offer such indemnity as may be satisfactory; and Cession of that it is contrary to the rules which should pre- Territory. vail among enlightened nations to proceed at once, and as a sine quâ non of peace, to transfer territory undoubtedly Peruvian, to the jurisdiction of Chili, without first demonstrating the inability or unwillingness of Peru to furnish indemnity in some other form.

"Such a course on the part of Chili would meet with decided disfavor on the part of the United States."

Similar action was taken by Kilpatrick in Chile. About the same time Mr. Blaine was further harassed by the suggestion of the French government that France, Great Britain, and the United States intervene in the South American war, to which he replied in good temper, but firmly:

"The United States has not belonged to that system of states, of which France and Great Britain are such important members, and has never participated in the adjustment of their contentions. Neither interest nor inclination leads this country to wish to have a voice in the discussion of those questions, but our relations to the states of the

No European Political Influence. American continent are widely different, and the situation is so nearly reversed that this government, while appreciating the high and disinterested motive that inspired the suggestion, is constrained to gravely doubt the expediency of uniting with European powers to intervene, either by material pressure or by moral or political influence, in the affairs of American states. . . . The interests, commercial and political, of the United States on this continent transcend in extent and importance those of any other power, and where these immense interests are deeply involved this government must preserve a position where its influence will be most independent and efficient." 
He wrote with less self-restraint to the ministers, who had certainly gone far beyond his instructions or expectations; and he sent a special envoy, Trescot, to straighten out the tangle, with instructions as follows:

"The United States, with which Peru has for many years maintained the most cordial relations, has the right to feel and express Joint a deep interest in its distressed condition, and while, American with equal friendliness to Chili, we will not interpose Intervention. to deprive her of the fair advantages of military success, nor put any obstacle to the attainment of future security, we cannot regard with unconcern the destruction of Peruvian nationality. If our good offices are rejected, and this policy of the absorption of an independent state be persisted in, this Government will consider itself discharged from any further obligation to be influenced in its action by the position which Chili has assumed, and would hold itself free to appeal to the other Republics of this continent to join in an effort to avert consequences which cannot be confined to Chili and Peru, but which threaten with extremest danger the political institutions, the peaceful progress, and the liberal civilization of all America."

Before this special mission could report, Mr. Blaine was out of office, for reasons in no way connected with his LatinAmerican policy. His successor, Frelinghuysen, was less eager. He offered friendly offices in settling a territorial controversy between the Argentine and Chile. In 1882, he protested against a cession of territory by Uruguay to Brazil, and he laid down the singular doctrine that -

"The Department of State will not sanction an intervention of European states in South American difficulties, even with the consent of the parties. The decision of American questions pertains to America itself."

He did not carry out Mr. Blaine's large idea of summoning an international American conference. Instead, Frelinghuysen "postponed" the meeting, which was not finally assembled until Blaine's second service as Secretary of State in 1889. 


\section{THE GAINS AND LOSSES OF SIXTEEN YEARS (1869-1885)}

The state of mind of the United States with regard to Latin America greatly changed during the terms of the three secretaries, Fish, Evarts, and Blaine. Within, the United States was rapidly growing in population and wealth, and the division between North and South was nearly healed. Trade, commerce, railroad-building, travel, and investments of capital spread far beyond the boundaries of the United States. It was the conviction of the State Department that the United States was tied up in all her Latin-American diplomacy by an unfavorable treaty with Great Britain, which that country failed to carry out in good faith and which was out of keeping with the modern conditions.

None of the three secretaries was successful in inducing the nation to back up his ideas of an American Doctrine. The country apparently would have preferred war with Spain to the peaceful settlement of the Cuban question; and Fish's plan of calling in a European concert to deal with it was so unwelcome that he did not think it wise to make the details known, even after the threat of that policy brought Spain to terms and secured the pacification of Cuba.

The Isthmus Canal was the clearest case of the need of a new national policy, by which the country could stand from decade to decade; and all the administrations were energetic on that subject. Fish complained of the Clayton-Bulwer Treaty; Hayes claimed the canal as part of the coast line; Blaine did his best to get rid of the treaty, by bluster or negotiation. On that question, however, none of them could strike fire. The geography of the Isthmus was still little known, and it was very uncertain whether the Panama or the Nicaragua route was the better. The press and Congress and the people at large seemed to be willing to let the results of the French company stand for themselves; they could not be galvanized into pressing for an immediate settlement of the Canal question.

Nor was the country ready for leadership in Latin America. The wars, losses, and devastations, which were so serious for those people, were at a great distance from this country. The nearest examples were Haiti and Santo Domingo, neither of which furnished a model of good government. Secretary 
Blaine was mercilessly attacked by a part of the press, and accused of a set policy of browbeating the warring powers of South America, a policy which he never authorized and which he tried to prevent. He was also accused of trying to make money for his friends out of the misfortunes of Peru.

Whatever the cause, no party, no section in the country, no leading statesman, was willing to propose that a single American soldier or sailor should be sacrificed in order to help the Latin-Americans to be better. If there were to be a change in public sentiment, something new must happen, and it was ten years more before the country was aroused to a sense of a national interest in Latin America. 


\section{Chapter XII}

\section{THE AMERICAN DOCTRINE AGAINST GREAT BRITAIN 1885-1898}

POLITICAL CONDITIONS (1885-1895)

DURING the next period, the one new statesman who impressed himself upon the whole nation was Grover Cleveland; and he was by nature, habits, and frame of mind undiplomatic. His direct thought and speech ; his simple methods of presenting his ideas; his hatred of forms, ceremonies, and artificial methods of thought and speech, - all made him unwilling to open up new questions or seek new principles of diplomacy. In his first administration Cleveland could not believe that the country was in danger of losing profits or prestige by attending strictly to its own internal affairs, and leaving our neighbors free to do the same. He felt that the vague hopes of annexation that were afloat, - Cuba, the Hawaiian Islands, possibly Canada, - were commercial schemes. He believed and practised upon the belief that no enlargement of boundaries was necessary either for defense or national pride. He felt that the great problem of the United States was to reform the national civil service, revise the tariff, and clear up the currency situation. He was little disturbed by the complications that came up with foreign countries, and thought them easy to adjust.

When Cleveland became President he took early occasion to say (December, 1885) :

"Maintaining, as I do, the tenets of a line of precedents from Washington's day, which proscribe entangling alliances with foreign states, I do not favor a policy of acquisition of new and distant territory or the incorporation of remote No Annexainterests with our own.

"... Our duty in the present instructs us to address ourselves mainly to the development of the vast resources of the great area committed to our charge and to the cultivation of the arts of 
peace within our own borders, though jealously alert in preventing the American hemisphere from being involved in the political problems and complications of distant governments.

His Secretary of State, Bayard, was an old-fashioned man whose policy was to keep his country out of adventure and to settle up outstanding difficulties of every kind. Almost the only passage in his despatches which seems to show a sense of national responsibility for the safety of Latin-American countries is the following :

" The United States has proclaimed herself the protector of this Western World, in which she is by far the stronger power, from the

Protection against European Invasion. intrusion of European sovereignties. She can point with proud satisfaction to the fact that over and over again has she declared, and declared effectively, that serious indeed would be the consequences if European hostile foot should, without just cause, tread those states in the New World which have emancipated themselves from European control. She has announced that she would cherish, as it becomes her, the territorial rights of the feeblest of these states, regarding them not merely as in the eye of the law equal to even the greatest of nationalities, but in view of her distinctive policy, as entitled to be regarded by her as the objects of a peculiarly gracious care. I feel bound to say that if we should sanction by reprisals in Hayti the ruthless invasion of her territory and insult to her sover-

No American Invasion. eignty which the facts now before us disclose, if we approve by solemn Executive action and Congressional assent that invasion, it will be difficult for us hereafter to assert that in the New World, of whose rights we are the peculiar guardians, these rights have never been invaded by ourselves."

In the next administration, that of Harrison, Blaine returned to office. He was older, his health was broken and he made no attempt to revive his former plans for a genuine leadership in America, preferring, as we shall see later, to draw our neighbors to us by commercial motives. Hence it was not till Richard Olney became Secretary of State in June, 1895, that a man in a position to give form to the external policy of his country came to the front; and Olney profoundly believed that the time had come to impress the world with the superior power of the United States in America. He therefore raised the American Doctrine beyond all previous bounds. 


\section{CANAL CONDITIONS (1885-1890)}

From 1881 to 1889 the French Company continued on its work and would probably have brought it to a point where it could have been taken up by other capital and finished, but for the superior power of the mosquito. Malaria and yellow fever cut down the labor supply ; and the impossibility of raising sufficient capital compelled the Company to stop in 1889, with about one third of the work done. An official investigation showed that the company had raised about $\$ 246,000,000$, of which about $\$ 187,000,000$ had been applied to finance and construction. Its concession, however, still held for a time, and was extended in 1893 to run to 1904 . The only reminder that the United States under the treaty of 1848 with Colombia, had a treaty-right to protect the Isthmus route was the occasional landing of marines or jackies on the Isthmus.

President Cleveland, soon after he was seated, withdrew the Zavala treaty with Nicaragua, which would have given the United States a special advantage in a rival canal route. In his annual message of 1885 he expressed himself strongly against a policy of expansion or of special territorial status.

"Therefore I am unable to recommend propositions involving paramount privileges of ownership or right outside of our own territory, when coupled with absolute and unlimited engagements to defend the territorial integrity of the state where such interests lie. While the general

No Paramount Privileges. project of connecting the two oceans by means of a canal is to be encouraged, I am of opinion that any schemes to that end to be considered with favor should be free from the features alluded to."

"Whatever highway may be constructed across the barrier dividing the two greatest maritime areas of the world must be for the world's benefit - a trust for mankind, to be removed from the chance of domination by any single power."

This policy of non-expansion was followed by President Cleveland in the Pacific. Military and commercial men were urging the annexation of the Hawaiian Islands, but he took no interest in that subject unless the Hawaiian people themselves should wish it. Still, he approved a treaty of 1887, extending the reciprocity treaty of 1875 , and granting the use of Pearl Harbor. In Samoa the United States had for some years held 
a footing; and in 1889 Germany, Great Britain, and the United States agreed to administer the islands in common.

So long as the French were at work on their canal, the only plan that seemed likely to head them off was to raise money and build on the Nicaragua route, without waiting to know whether they would succeed or fail. An American Nicaragua Canal Company was organized in 1884, and in 1889 Congress chartered an American canal company which secured a concession from Nicaragua, made surveys and in 1890 began a little work. The charter of the Company was a blow at the ClaytonBulwer Treaty. The proprietors always expected the government to come to their rescue; and barely failed to secure an act of Congress by which their bonds should be guaranteed by the government.

Though Cleveland had very little to say about either Canal, President Harrison in his inaugural, March 4, 1889, took it up.

"We have happily maintained a policy of avoiding all interference with European affairs. We have been only interested spectaNo Euro- tors of their contentions in diplomacy and in war, pean $\quad$ ready to use our friendly offices to promote peace, but Domination never obtruding our advice and never attempting of a Canal. unfairly to coin the distresses of other powers into commercial advantage to ourselves. We have a just right to expect that our European policy will be the American policy of European courts. It is so manifestly incompatible with those precautions for our peace and safety which all the great powers habitually observe and enforce in matters affecting them that a shorter waterway between our eastern and western seaboards should be dominated by any European Government that we may confidently expect that such a purpose will not be entertained by any friendly power."

Up to this time it was not certain that a Canal could actually be constructed either in Panama or in Nicaragua. A controversy arose between the two routes, backed up by newspapers, special publications, and speeches in Congress. There were "friends of Nicaragua", exactly as there were "friends of silver" and "friends of protection." Still, so long as the physical possibility of any canal was not proved, the choice of routes did not cause anxiety. 


\section{RECIPROCITY WITH LATIN AMERICA (1884-1897)}

The immense expansion of the manufactures and trade of the United States after the Civil War was certain to raise new questions of interest and responsibility. Up to that time the relations with Latin America were much more affected by reasons of general policy than by commercial motives. The United States was busy in other pursuits and made little effort to attract her neighbors' trade. Most of South America was as near to Great Britain as to the United States. European bankers and business men were established in that part of the world, and few North Americans. The products of Latin America were mostly agricultural, such as grain, coffee, rubber, hides, and sugar; or minerals, such as the nitrates and precious metals. The imports were chiefly manufactures and articles of luxury, in which European goods had the preference. The high tariff in the United States produced a surplus revenue, which led to a movement to drop the existing duties on sugar and coffee, and this suggested that more liberal imports of those articles from Latin America ought to be balanced by exports of American manufactures. Could not this trade be pushed by some sort of government action?

The most obvious method was to grant a subsidy on vessels engaged in trade to South America; but there was a strong feeling in Congress against ship subsidies; and a rival suggestion gained ground to the effect that what was needed was a system of specially favoring commercial treaties which would draw the trade northward. In 1884, President Arthur sent a special commission through Mexico, Central America, and the South American countries to study the question. President Cleveland, so far as he could, ignored the Commission when he came into office; and its report had little effect. His remedy was to cut down the tariff as a whole and thus to encourage general foreign trade.

When Harrison became President in 1889 and appointed Blaine as his Secretary of State, a new influence began to work in Congress. The Republican party set about framing the McKinley Tariff of 1890 and Blaine suggested and urged with all his might that the tariff be so constructed as to compel the South American countries to give a favored place to American trade. When the bill came before the Senate, he wrote- 
"There is not a section or line in the entire bill that will open a market for another bushel of wheat or another barrel of pork."

\section{Under pressure from this powerful party chief, the act as passed included the following provision :}

" That with a view to secure reciprocal trade with countries producing the following articles, . . . whenever, and so often as the Compulsory President shall be satisfied that the Government of Reciprocity. any country producing and exporting sugars, molasses, coffee, tea, and hides, raw and uncured, or any of such articles, imposes duties or other exactions upon the agricultural or other products of the United States, which in view of the free introduction of such sugar, molasses, coffee, tea, and hides into the United States he may deem to be reciprocally unequal and unreasonable, he shall have the power and it shall be his duty to suspend, by proclamation to that effect, the provisions of this act relating to the free introduction of such sugar, molasses, coffee, tea, and hides, the production of such country, for such time as he shall deem just."

Secretary Blaine at once began to serve notices under this act, and the result was that at the end of two years he was able to report that he had concluded eight treaties by which LatinAmerican states (or European governments for their American colonies) agreed to make concessions which would satisfy the conditions of the Act, and enable them to enjoy the free-list on their exports. All these treaties went out of existence when, in 1894, the Wilson Tariff was passed. In 1897 the Dingley Tariff made a more general provision:

" That whenever the President of the United States, by and with the advice and consent of the Senate, with a view to secure reciproReciprocity cal trade with foreign countries, shall, within the Treaties. period of two years from and after the passage of this Act, enter into commercial treaty or treaties with any other country or countries concerning the admission into any such country or countries of the goods, wares, and merchandise of the United States ... and in such treaty or treaties, in consideration of the advantages accruing to the United States therefrom, shall provide for the reduction during a specified period, not exceeding five years, of the duties imposed by this Act, to the extent of not more than twenty per centum thereof, upon such goods, wares, or merchandise as may be designated therein ... or shall provide for the transfer during such period from the dutiable list of this Act to the free list thereof of such goods, wares, and merchandise, being the natural products 
of such foreign country or countries and not of the United States; or shall provide for the retention upon the free list of this Act during a specified period, not exceeding five years . . . and when any such treaty shall have been duly ratified by the Senate and approved by Congress, and public proclamation made accordingly, then and thereafter the duties which shall be collected by the United States upon any of the designated goods, wares, and merchandise from the foreign country with which such treaty has been made shall, during the period provided for, be the duties specified and provided for in such treaty, and none other."

Notwithstanding the sanction of the Republican party and the public interest in Latin America, not a single one of the seven treaties which McKinley negotiated was ratified by the Senate. The high tariff influence was against any lessening of any duties, by any process or for any purpose. From that time to the present day, nothing has been done to put Latin America on an especially favored trade footing, except a limited ship subsidy. Under an act of 1891, a postal subsidy was allowed to vessels engaged in South American trade; ever since that time payments averaging about $\$ 300,000$ a year in excess of regular mail payments have been made on that account.

\section{PAN-AMERICAN CONGRESS（1889-1890）}

One of the few indications that President Cleveland was interested in Latin America was a call for a Pan-American Congress sent out by Secretary Bayard in 1888. By a whimsical turn of fate, the Secretary of State who received the delegates at Washington in October, 1889, was James G. Blaine, who thus carried out the plan he had urged in 1881. To this PanAmerican Congress came delegates from the Empire of Brazil, and from all the Latin-American republics, except Santo Domingo and Uruguay.

The sessions of the Congress continued until April, 1890, when it adjourned, after drawing up a long series of proposed conventions and experiments. Among them was a "uniform treaty of arbitration, between the republics of North, Central, and South America." Recommendations were made for an Inter-American railway, bank, and monetary union. One convention provided for the navigation of the international rivers. Another drafted a uniform system of customs regulations; 
One set of resolutions, suggested by the writings of the publicist, Calvo, was intended to meet the complaint that foreigners in Latin-American countries were supported by their governments in a privileged status. It read as follows:

"Foreigners are entitled to enjoy all the civil rights enjoyed by natives; and they shall be accorded all the benefits of said Rights of rights in all that is essential as well as in the form Foreigners. or procedure, and the legal remedies incident thereto, absolutely in like manner as said natives.

"A nation has not, nor recognizes in favor of foreigners, any other obligations or responsibilities than those which in favor of the natives are established, in like cases, by the constitution and the laws."

The Congress felt that something ought to be done to put a stop to the desperate struggle for territory between LatinAmerican countries; and also appeared to wish some sort of defense against invasion by foreign powers. Hence it passed the following series of resolutions, which were put into final form by Secretary Blaine :

" 1 . That the principle of conquest shall not, during the continuance of the treaty of arbitration, be recognized as admissible

No Terri-

torial Con-

quests. continuance of the treaty of arbitration, shall be void

" 3 . Any nation from which such cessions shall be exacted may demand that the validity of the cessions so made shall be submitted to arbitration.

" 4 . Any renunciation of the right to arbitration, made under the conditions named in the second section, shall be null and void."

The main fault of this Pan-American Congress was that it ran away from its constituents. The only vote that actually took effect was for the formation of a Latin-American Library which later developed into the Bureau of American Republics, a sort of central clearing house at Washington for information about America. Otherwise, not a single one of the many conventions proposed by the Congress was carried out. They needed unanimous acceptance, and could not secure any considerable number of ratifications. Nevertheless the conference showed the possibility of friendly exchange of views under 
the presidency of the United States; and the delegates were more impressed than the circumstances warranted, with the interest of the United States, and her desire to work hand in hand with her American sisters.

\section{DIFFICULTIES WITH CHILE AND BRAZIL (1891-1894)}

In spite of many dragging difficulties of diplomatic relations with weak and irresponsible governments, the United States had not since the Paraguay expedition of 1859 threatened hostilities with a Latin-American neighbor. In 1892 a diplomatic crisis arose with Chile. The Chilean President for the time being, Balmaceda, in 1891 attempted to set himself up as a dictator and was resisted by the Congressional party. Eventually that party was successful, though it felt that American ships on their station were helpful to the President's forces. A steamer belonging to the Congressional party, the Itata, left the port of San Diego, California, by stealth; and an unwarrantable attempt was made by the United States to seize her on the high seas. The American minister, Egan, harbored Balmaceda and others of his party in the American legation at Santiago, and claimed for them a right of asylum.

While these grievances were still in the minds of the Chileans, two hundred sailors from the American ship Baltimore were allowed to go on shore $>$ at Valparaiso. A difficulty arose, in which the police took a hand; and some of the Baltimore sailors were killed. The United States demanded redress and when the proceedings of investigation dragged along, President Harrison issued a high-strung message (January 25, 1892). Without precisely suggesting war, he asked "the attention of Congress for such action as may be deemed appropriate"; and he strongly expressed the duty of the United States to take strong action in Latin America in such cases, in the following passage :

"It has been my desire in every way to cultivate friendly and intimate, relations with all the Governments of this hemisphere. We do not covet their territory. We desire their peace and prosperity. We look for no advantage in our relations with them except the increased exchanges of commerce upon a basis of mutual benefit. We regret every civil contest that disturbs their peace

Protection within

LatinAmerican Countries. 
and paralyzes their development, and are always ready to give our good offices for the restoration of peace. It must, however, be understood that this Government, while exercising the utmost forbearance toward weaker powers, will extend its strong and adequate protection to its citizens, to its officers, and to its humblest sailor when made the victims of wantonness and cruelty in resentment not of their personal misconduct, but of the official acts of their Government."

While this message was being read to Congress an apology from Chile, which had been demanded several days before, was being deciphered at the State Department. A few hours' delay would have made the message unnecessary. The provocation by the Chileans was exasperating; the attitude of the United States to Chile was overbearing. The most serious thing about the whole controversy was that it presented to the Latin-American mind an American policy of willingness to take sides in the internal struggles of a Latin-American state; and an unwillingness to apply her own principles of neutrality and sympathy and republican government. The usual policy of the United States in such difficulties was one of forbearance and good temper ; the result of sixty years' efforts to make our good will clear to our neighbors, was overcast by a petulant threat of war.

Less sympathy with the revolutionists was shown in the attitude of the United States toward an insurrection of Brazilian naval vessels, in the harbor of Rio, in 1893-94. The insurgents threatened to prevent the landing of goods from American merchant vessels. The commanders of foreign squadrons in the harbor united in a notice that they would protect the peaceful commerce of their national vessels with the city. Admiral Benham for the United States saw evidence of intention to stop the landing from American ships, and gave notice that he would fire if necessary. The point was that the United States had not recognized the belligerency of the insurgents, and would not permit interruption of usual commerce at their hands.

\section{VENEZUELA CONTROVERSY (1881-1895)}

When Cleveland returned to the Presidency in 1893, he found a rising tide of interest in the Canal which showed itself in various schemes for completing the Nicaragua Canal, 
or taking over the French ditch and completing it. His Secretary of State, Gresham, was not a man of weight; but in June, 1895, he transferred his Attorney-General, Richard Olney, to that post; and within six months the country was electrified by a new version of the American Doctrine, which purported to be simply an application of the Monroe Doctrine.

One of the curiosities of American geography is the existence of the three little colonies of British Guiana, French Guiana, and Dutch Guiana on the north coast of South America. These relics of Eighteenth-Century conditions are of little political or military importance. The population at present in British Guiana is supposed to be about 300,000 , of whom perhaps 3,000 are Europeans and direct descendants of Europeans. The colony stretches northwestward to the neighborhood of the mouth of the Orinoco, where it abuts on the Republic of Venezuela. Between the two neighbors a boundary dispute arose, which went back to Dutch claims of 1613 , which were acquired by the English in 1814. In 1840 the English extended their previous claims far westward in the interior, and from time to time they shoved the nominal line still farther. The Venezuelan government in 1881 began to ask for arbitration, and in 1887 formally protested against the British action and terminated direct diplomatic relations with Great Britian. The grieved American republic appealed for sympathy and aid to the United States, which in 1886 requested Great Britian to arbitrate, and Bayard lightly alluded to a Doctrine announced two generations ago, but expressed his confidence that -

"It is not supposed for a moment that any idea of political or territorial expansion of authority on the American continent can control Her Majesty's counsellors in any action they may take in relation to Venezuela."

In July, 1894, Secretary Gresham again urged the matter on the attention of the British Government.

The United States had little reason for special friendship with Venezuela. From 1866 to 1895 there was a current of negotiation over claims against Venezuela, several of which were settled by arbitration; and it was natural that Venezuela should expect the United States to aid in bringing about a similar method of settlement with her powerful neighbor. 
The controversy went back to doubtful settlements, uncharted explorations, and movable boundary marks. So far as it was capable of decision on evidence, Great Britain seemed to have the better case; but Venezuela was passionately convinced that her just rights were disregarded. The contemptuous refusal of Great Britain to give an opportunity to present the case to an impartial tribunal made Venezuela furious, and showed also a British disregard of the requests of the United States. The United States had just arbitrated the Bering Sea controversy with Great Britain and had accepted an adverse finding. She had some right to think that that method of settlement was acceptable to Great Britain. Under a hint from the State Department, Congress (February, 1895) passed a resolution urging "friendly arbitration."

Nevertheless, the people at large were little interested in the affair, and had no notion that essential rights and interests of the United States were involved. Hence the country was taken completely by surprise when, December 17, 1895, President Cleveland sent in a special message to Congress demanding arbitration as a right of the United States, and winding up with the significant remark -

"In making these recommendations I am fully alive to the responsibility incurred and keenly realize all the consequence that may follow."

\section{THE OLNEY DOCTRINE (1895)}

Cleveland's message was founded upon a despatch sent to Great Britain July 20, 1895, - of course with the President's approval, - which was answered by Lord Salisbury, November 26. Olney's despatch contained an elaborate exposition of what he called the Monroe Doctrine. He pointed out that several previous Secretaries of State had called the attention of England to "our friendly concern", and to "the sense of responsibility that rests upon the United States in relation to the South American Republics." He then lays down the broad principle :

" That there are circumstances under which a nation may justly interpose in a controversy to which two or more other nations are the direct and immediate parties is an admitted canon of international law." 
He reviews the history of what he believes to be the original Monroe Doctrine, basing it on the Doctrine of the Two Spheres, and he then sums up especially the colonization principle as follows :

"The precise scope and limitations of this rule cannot be too clearly apprehended. It does not establish any general protectorate by the United States over other American states. It does not relieve any American state from tion. its obligations as fixed by international law nor prevent any European power directly interested from enforcing such obligations or from inflicting merited punishment for the breach of them. . . It does not justify any attempt on our part to change the established form of government of any American state or to prevent the people of such state from altering the form according to their own will and pleasure. The rule in question has but a single purpose and object. It is that no European power or combination of European powers shall forcibly deprive an American state of the right and power of self-government and of shaping for itself its own political fortunes and destinies."

The remainder of the despatch is an exposition and glorification of what Secretary Olney calls the Monroe Doctrine, which may be arranged as follows:

" That the rule thus defined has been the accepted public law of this country ever since its promulgation cannot fairly be denied. Its pronouncement by the Monroe administration at that particular time was unquestionably due to the

Public Law. inspiration of Great Britain, who at once gave to it an open and unqualified adhesion which has never been withdrawn. . . . The foregoing enumeration not only shows the many instances wherein the rule in question has been affirmed and applied, but also demonstrates that the Venezuelan boundary controversy is in any view far within the scope and spirit of the rule as uniformly accepted and acted upon. A doctrine of American public law thus long and firmly established and supported could not easily be ignored in a proper case for its application, even were the considerations upon which it is founded obscure or questionable. . . .

"It is manifest that, if a rule has been openly and uniformly declared and acted upon by the executive branch of the Government for more than seventy years without express repudiation by Congress, it must be conclusively presumed to have its sanction. Yet it is certainly no more than Authority of the Executive. the exact truth to say that every administration since President 
Monroe's has had occasion, and sometimes more occasions than one, to examine and consider the Monroe doctrine and has in each instance given it emphatic endorsement. . . .

"The Monroe doctrine understood and defined in the manner already stated ... rests . . . upon facts and principles that are To Perma- both intelligible and incontrovertible. That distance nent Colo- and three thousand miles of intervening ocean make nies.

any permanent political union between an European and an American state unnatural and inexpedient will hardly be denied. But physical and geographical considerations are the least of the objections to such a union. Europe, as Washington observed, has a set of primary interests which are peculiar to herself. America is not interested in them and ought not to be vexed or complicated with them. . . .

"Europe as a whole is monarchical, and, with the single important exception of the Republic of France, is committed to the No Mon- monarchical principle. America, on the other hand, archies. is devoted to the exactly opposite principle - to the idea that every people has an inalienable right of self-government and, in the United States of America, has furnished to the world the most conspicuous and conclusive example and proof of the excellence of free institutions, whether from the standpoint of national greatness or of individual happiness. . . .

"Is it true, then, that the safety and welfare of the United States are so concerned with the maintenance of the independence of every Sympathetic Alliance with SouthAmerican States. American state as against any European power as to justify and require the interposition of the United States whenever that independence is endangered? The question can be candidly answered in but one way. The states of America, South as well as North, by geographical proximity, by natural sympathy, by similarity of governmental constitutions, are friends and allies, commercially and politically, of the United States. To allow the subjugation of any of them by an European power is, of course, to completely reverse that situation and signifies the loss of all the advantages incident to their natural relations to us. But that is not all. The people of the United States have vital interest in the cause of popular self-government. . . .

"To-day the United States is practically sovereign on this continent, and its fiat is law upon the subjects to which it confines

Sovereignty of the United States in North America. its interposition. Why? It is not because of the pure friendship or good will felt for it. It is not simply by reason of its high character as a civilized State, not because wisdom and justice and equity are the invariable characteristics of the dealings of the 
United States. It is because, in addition to all other grounds, its infinite resource combined with its isolated position render it master of the situation and practically invulnerable as against any or all other powers. . . .

"The people of the United States have learned in the school of experience to what extent the relations of the states to each other depend not upon sentiment nor principle, but upon selfish interest. They will not soon forget that, in their hour of distress, all their anxieties and burdens and France. were aggravated by the possibility of demonstrations against their national life on the part of powers with whom they had long maintained the most harmonious relations. They have yet in mind that France seized upon the apparent opportunity of our civil war to set up a monarchy in the adjoining state of Mexico. They realize that had France and Great Britain held important South American possessions to work from and to benefit, the temptation to destroy the predominance of the Great Republic in this hemisphere by furthering its dismemberment might have been irresistible.

"There is, then, a doctrine of American public law, well founded in principle and abundantly sanctioned by precedent, which entitles and requires the United States to treat as an injury to itself the forcible assumption by an European power of political control over an American state. The application of the doctrine to the boundary

No Euro-

pean control of American States. dispute between Great Britain and Venezuela remains to be made and presents no real difficulty. Though the dispute relates to a boundary line, yet, as it is between states, it necessarily imports political control to be lost by one party and gained by the other. . . . It has been intimated, indeed, that in respect to these South American possessions Great Britain is herself an American state like any other, so that a controversy between her and Venezuela is to be settled between themselves as if it were between Venezuela and Brazil or between Venezuela and Colombia, and does not call for or justify United States intervention. If this view be tenable at all,

Great

Britain

not an

American

State. the logical sequence is plain.

"Great Britain as a South American state is to be entirely differentiated from Great Britain generally, and if the boundary question cannot be settled otherwise than by force, British Guiana, with her own independent resources and not those of the British Empire, should be left to settle the matter with Venezuela. Great Britain cannot be deemed a South American state within the purview of the Monroe doctrine, nor, if she is appropriating Venezuelan territory, is it material that she does so by advancing 
the frontier of an old colony instead of by the planting of a new colony. . . .

"Great Britain's assertion of title to the disputed territory combined with her refusal to have that title investigated being Warning to a substantial appropriation of territory to her own use, Great Britain. not to protest and give warning that the transaction will be regarded as injurious to the interests of the people of the United States as well as oppressive in itself would be to ignore an established policy with which the honor and welfare of this country are closely identified. . . . The foregoing views .... call for a definite decision upon the point whether Great Britain will consent or will decline to submit the Venezuelan boundary question in its entirety to impartial arbitration."

\section{THE CLEVELAND DOCTRINE（1895）}

These despatches were made public together with Cleveland's message, and that document accepts Olney's principles and phrases, some of them in a more condensed and racy style. The precise form of Cleveland's view of the American Doctrine is important, because he was the first President after Polk to commit himself to a detailed official statement of American relations :

"Without attempting extended argument in reply to these positions, it may not be amiss to suggest that the doctrine upon which

American

Peace and

Safety

Controlling. form of government. It was intended to apply to every stage of our national life and can not become obsolete while our Republic endures. ...

"If a European power by an extension of its boundaries takes possession of the territory of one of our neighboring Republics European Political System. against its will and in derogation of its rights, it is difficult to see why to that extent such European power does not thereby attempt to extend its system of government to that portion of this continent which is thus taken. This is the precise action which President Monroe declared to be $\therefore$ dangerous to our peace and safety.' ...

"Practically the principle for which we contend has peculiar, if not exclusive, relation to the United States. It may not have been admitted in so many words to the code of international law, 
but since in international councils every nation is entitled to the rights belonging to it, if the enforcement of the Monroe doctrine is something we may justly claim it has its place in the code of international law as certainly and as securely as if it were specifically mentioned; and when the United States is a suitor before a high tribunal

Monroe

Doctrine is

Interna-

tional Law. that administers international law the question to be determined is whether or not we present claims which the justice of that code of law can find to be right and valid.

" The Monroe doctrine finds its recognition in those principles of international law which are based upon the theory that every nation shall have its rights protected and its just claims enforced.

". . . The dispute has reached such a stage as to make it now incumbent upon the United States to take measures to determine with sufficient certainty for its justification what is the true divisional line between the Republic of Venezuela and British Guiana. The inquiry to that end should of course be conducted carefully and judicially. . . .

Resistance

by the

United

States. When such report is made and accepted it will, in my opinion, be the duty of the United States to resist by every means in its power, as a willful aggression upon its rights and interests, the appropriation by Great Britain of any lands or the exercise of governmental jurisdiction over any territory which after investigation we have determined of right belongs to Venezuela."

\section{THE SALISBURY DOCTRINE（1895）}

The reply of Lord Salisbury shows the astonishment of that illustrious statesman at what he looked upon as a new and unaccountable freak of American diplomacy. His principal objections were as follows:

"The contentions set forth by Mr. Olney in this part of his despatch are represented by him as being an application of the political maxims which are well known in American discussion under the name of the Monroe doctrine. As far as I am aware, this doctrine has never been before advanced on behalf of the United States in any written communication addressed to the Government

Official

Communication of the

Monroe

Doctrine. of another nation; but it has been generally adopted and assumed as true by many eminent writers and politicians in the United States. ... .

"The dangers which were apprehended by President Monroe have no relation to the state of things in which we live at the 
present day. There is no danger of any Holy Alliance imposing Change of its system upon any portion of the American ConConditions. tinent, and there is no danger of any European State treating any part of the American Continent as a fit object for European colonization. ...

" It is a controversy with which the United States have no apparent practical concern. It is difficult, indeed, to see how it can Venezuelan materially affect any State or community outside Dispute out- those primarily interested. . . . The disputed
side the Monroe frontier of Venezuela has nothing to do with any of Doctrine. the questions dealt with by President Monroe. It is not a question of the colonization by a European Power of any portion of America. It is not a question of the imposition upon the communities of South America of any system of government devised in Europe. It is simply the determination of the frontier of a British possession. . . .

"But the claim which he founds upon them is that, if any inde-

American

Claim to

Interposi-

tion. pendent American State advances a demand for territory of which its neighbour claims to be the owner, and that neighbour is the colony of a European State, the United States have a right to insist that the European State shall submit the demand, and its own impugned rights to arbitration.

". . . I have argued on the theory that the Monroe doctrine in itself is sound. I must not, however, be understood as expressing any

Monroe

Doctrine

not Inter-

national

Law. acceptance of it on the part of Her Majesty's Government. . . International law is founded on the general consent of nations; and no statesman, however eminent, and no nation, however powerful, are competent to insert into the code of international law a novel principle which was never recognized before, and which has not since been accepted by the Government of any other country. . . .

"The Government of the United States is not entitled to affirm as a universal proposition, with reference to a number of independent States for whose conduct it assumes no responsibility, that its interests are necessarily concerned in whatever may befall those States simply because they are situated in the Western Hemisphere. . . . "Though the language of President Monroe is directed to the attainment of objects which most Englishmen would agree to be salutary, it is impossible to admit that they have been inscribed by any adequate authority in the code of international law ; and the danger which such admission would involve is sufficiently exhibited both by the strange development which the doctrine has received at Mr. Olney's hands, and the arguments by which it is supported. . . . 
"The necessary meaning of these words is that the union between Great Britain and Canada; between Great Britain and Trinidad ; between Great Britain and British Honduras or British Guiana are 'inexpedient and unnatural.' President Monroe disclaims any such inference from his doctrine; but in this, as in other respects, Mr.

Right to maintain British Colonies. Olney develops it. He lays down that the inexpedient and unnatural character of the union between a European and American State is so obvious that it 'will hardly be denied.' Her Majesty's Government are prepared emphatically to deny it on behalf of both the British and American people who are subject to her Crown. They maintain that the union between Great Britain and her territories in the Western Hemisphere is both natural and expedient. They fully concur with the view which President Monroe apparently entertained, that any disturbance of the existing territorial distribution in that hemisphere by any fresh acquisitions on the part of any European State would be a highly inexpedient change. But they are not prepared to admit that the recognition of that expediency is clothed with the sanction which be-

Venezuelan Dispute outside the Monroe Doctrine. longs to a doctrine of international law. They are not prepared to admit that the interests of the United States are necessarily concerned in every frontier dispute which may arise between any two of the States who possess dominion in the Western Hemisphere; and still less can they accept the doctrine that the United States are entitled to claim that the process of arbitration shall be applied to any demand for the surrender of territory which one of those States may make against another."

\section{THE LODGE DOCTRINE（1895）}

Henry Cabot Lodge of Massachusetts, a Senator of long experience of foreign relations and a well-known American historian, presented a somewhat drastic view of the situation, and stated his conception of the American doctrine as follows:

"It is not a doctrine of international law, and the attempt to discuss it or to oppose it on that ground is a waste of words. Like the independence of this country, it is a question of fact and not of law. The independence of this country

Self-preseris unquestioned, because, having declared it, we compelled the world to recognize it. In the same way we have always acted on the declaration of Mr. Monroe as the guiding principle of our foreign policy. We shall now, I hope, declare it again with the 
formal sanction of Congress, representing the people of the United States. It is idle to argue either for or against it as a matter of international law, for it requires no such support. We stand by the Monroe doctrine for the same reason that England upholds Afghanistan, and takes the Shan States from China, because it is essential to our safety and our defence. The Monroe Doctrine rests primarily on the great law of self-preservation.

"We declare the Monroe doctrine to be a principle which we believe essential to the honor, the safety, the interests of the Authority United States. We declare it as a statement of fact, of the United

States. and we must have it recognized as our independence and national existence are recognized by all the world. It must be recognized, because we sustain and support it, and we can no more permit it to be a matter of discussion with other nations than we can afford to discuss with them our national welfare or our forms of government. It embodies for us the same principle as the balance of power so jealously maintained by the nations of Europe. They will not allow that to be disturbed, and we hold to our balance of power with equal tenacity.

"The Monroe doctrine interferes in no wise with the rights which the principles of international law give to all nations. It does not touch the question of reparation for injuries inflicted upon the subjects of any European power by any of the Central or South American States. We cherish that right jealously ourselves; we do not deny it to others. . . .

"The Monroe doctrine ... is merely the declaration that no foreign power must establish a new government, acquire new No Change territory by purchase or force or by any method of American whatever, or seek to control existing Governments Status. in the Americas. That is the principle which Mr. Monroe declared. If there is any dispute as to the meaning of his language, it is not needful to dwell upon it. That is what the American people believed he meant. That is the way American statesmen have interpreted it, and that there may be no future misunderstanding, that is what we should declare it to be and to have always been by this resolution."

\section{OCCASION OF THE CLEVELAND-OLNEY DOCTRINE}

The positive and deliberately offensive despatch and message seem to have been an entire surprise to Lord Salisbury and the British people. For some weeks he could hardly believe that there would not be a storm of criticism and objection in the 
United States before which the Administration would be obliged to give way. Some stout critics did refuse to see any necessary connection between a "European political system" and a boundary controversy; but it was soon clear that the overwhelming public sentiment of the United States, however surprised at the tone of the documents, accepted the assurance of the President and Secretary of State that the country was somehow in danger. Those assurances were all that the country ever had, for to this day it is uncertain what was the real cause of the outburst. Olney never has shown the public evidence that the British government had any plan of introducing strife and difficulty into Latin-American relations. President Cleveland long after published a magazine article in which the only explanation is in the following hazy phrases:

"It was necessary in order to assert and vindicate a principle distinctly American ... O Our Government interposed to prevent any further colonization of American soil by a European nation. ... We needed proof of the limits of her rights in order to determine our duty in defense of the Monroe Doctrine."

The chief reason for Cleveland's policy was not a love for arbitration, for when Great Britain suggested that the dispute with the United States be arbitrated, he declined that proposition. The government and people of Venezuela were not in immediate danger from the occupation of an almost unpeopled area. The United States was not seeking adventures, for the new doctrine was expressly based upon "American non-interference in European affairs." No previous President or Secretary of State had ever taken such broad and sweeping ground. Olney declared that "any permanent political union between a European and an American state was unnatural and inexpedient"; that the interests "of Europe are irreconcilably diverse from those of America"; that "to-day the United States is practically sovereign on this continent, and its fiat is law upon the subjects to which it confines its interposition"; that it is "master of the situation." These weighty declarations were further asserted to be at once a reassertion of Monroe's doctrine, and a permanent principle of international law for American relations. Whether sound or otherwise, they are so little related to the doctrine of 1823 that one is tempted to apply to Secretary Olney's argument the Oxford under- 
graduate's account of a football game: "It would have been just as good a fight without the ball ; the ball was only in the way." It is difficult to resist the conviction that Olney's doctrine would have had more force if it had stood out boldly on the principle of "permanent national interest." Monroe added no strength to his position.

Among the reasons suggested for the Olney doctrine is that it was the desire of the administration to block the way to British expansion in the direction of the Isthmus of Panama. This theory is that the United States was fast moving toward a national Canal, and must begin to cut off points of vantage held by other powers. A sufficient answer is that British Guiana does not approach the Isthmus; it is 500 miles further from Panama than is the Southern cape of Florida. It is impossible to connect the mouth of the Orinoco with any form of Isthmus doctrine.

If one must grope for an explanation, the most likely one is that President Cleveland felt a genuine and perhaps wellgrounded conviction that Great Britain was holding on too tightly in America; Canada was growing; the West India Islands were all loyal; the English still adhered to a strip of the coast of Central America, and had not been shaken out of the Clayton-Bulwer Treaty. We may guess that Secretary Olney shared this feeling, and selected a question in which the United States was not much interested, but which might serve as a peg on which to hang an assertion of her power, dignity, and policy in America. The political enemies of the administration taunted it with being pro-English: here was an opportunity to disprove that charge; at the same time to help a suffering fellow-American State, and to make the world aware that from the Arctic Ocean to Tierra del Fuego the most powerful political force was the United States of America. Olney later seemed to realize that he had uncorked a genii, which he was unable to return to the bottle in which King Solomon had once sealed him up. In accordance with the suggestion of the President, an ex parte commission was appointed to examine the evidence; but long before it could report, Great Britain gave way, submitted to the desired arbitration, and practically accepted the American government as counsel for Venezuela. 
STATE OF THE MONROE DOCTRINE IN 1898

The three administrations of Cleveland, Harrison, and Cleveland again, show the first efforts since Seward's Mexican diplomacy to stand as defenders between American and European powers. That policy was obliged to contend against public indifference. President Cleveland washed his hands of annexations and intervention. Mr. Blaine secured a plan of reciprocity in trade which, if carried out, would have done much to attach the Latin neighbors, and in the Pan-American Congress he gave a strong impulse to the forces which were making for union of sentiment among all the Latin-American Republics. Harrison's attitude was weakened by his sharp tone to Chile, but Cleveland and Olney more than made up for this set-back by the intensity of their defense of Venezeta, a weak power which had a weak case.

Here is another turning-point between the Monroe Doctrine and the American Doctrine. Both these doctrines were founded upon the interest of the United States ; but most early presidents took the ground that what benefited and improved Latin America must be helpful to us. Olney put into words and a great many words - the theory which Evarts had summed up in the one phrase "paramoun't interest"; and he followed with the zeal of a new disciple the theory of the exclusion of Great Britain in America, which had been more brutally stated years before by Douglas, and less pointedly by President Grant. He was opposed to monarchies, disliked them in Europe and condemned them in America. On that point his case was strengthened by the action of Brazil, which in 1889 became a Republic and in 1891 a Federal Republic. Olney especially disliked England in America, denied her the status of an American power; predicted the loss of the British colonies; and called public attention to English selfishness in contrast with American uprightness and international kindness. The chief fault of England, however, he did not mention - that was, the possession of an equal share in a future Isthmus Canal. It is hard to resist the conviction that this was the real object of Olney's attack. Whatever his motives, the result was the surrender within five years of that position of British vantage. After the first shock of surprise, Lord Salisbury bowed to the inevitable and agreed to an arbi- 
tration with Venezuela, which by humorous good fortune was decided almost completely in favor of Great Britain. Nevertheless Salisbury did all that he could to turn the public sentiment of his country in the direction of friendship and good understanding with the United States. All the suavity of Seward, the courtesy of Evarts, and the finesse of Blaine, had not availed to break up the notion that the British Empire was a great power in America as well as in Europe, Asia, Africa, and Australia. The rough and inconsiderate despatches of Olney and the undiplomatic firmness of Cleveland accomplished that miracle. 


\section{Chapter XIII}

\section{THE WEST INDIES AND THE CANAL 1898-1903}

\section{CUBAN INSURRECTION (1895-1898)}

IN the midst of the despatches on the Venezuelan question another problem was looming up. The Cubans, whose leaders had been collecting funds, organizing, and getting ready for nearly twenty years, for a second time revolted and formed what they called a Cuban Republic. Their Congress never met, their courts did not exist, their executive government was a few men in the saddle, and their army never fought a pitched battle in the open field. The insurgents depended on the kind of guerrilla warfare that had devastated Cuba in the first insurrection. As at that time, many of the owners of plantations and other property sided with the Spanish government; as in the previous insurrection, fighting went on several years without any definite result.

The people of the United States were from the first involved in this civil war, for many reasons: the insurrection cut off part of their trade; some Americans who lived in Cuba or visited it were harshly treated; they felt the old natural sympathy with patriots battling for their liberty against a colonial master. President Cleveland did all that he could to stand neutral, so long as he was in office; he resisted a strong popular pressure for recognizing the independence of the shadowy Cuban government. Meantime, the familiar cry of annexation arose again.

Here was a straightforward contest between a Spanish colony and a Spanish home government: and the precedent of twenty years before was very strong in favor of the right of Spain to carry on such a conflict without coming under the ban of the American Doctrine. However, the old Monroe Doctrine was 
now enlarged. Under Cleveland's guidance the country had accepted as the normal principle the conception that it must have a voice in all such questions in America. As the Cuban insurrection continued from month to month, the pressure grew for interposition. Secretary Olney, April 4,-1896, wrote to the Spanish government on this subject:

“The people of the United States . . . are interested in any struggle anywhere for freer political institutions, but necessarily and Allowable in special measure in a struggle that is raging almost Interven- in sight of our shores. . . . The interest of the United tion.

States in the existing situation in Cuba yields in extent only to that of Spain herself, and has led many good and honest persons to insist that intervention to terminate the conflict is the immediate and imperative duty of the United States ... the United States can not contemplate with complacency another ten years of Cuban insurrection, with all its injurious and distressing incidents."

A mighty vista was opened to the American people by the chance of Cuba's separation. The island lay athwart the entrances into the Gulf of Mexico. Commercial ties were close, and Cuba was a place for profitable investment, if it ceased to be Spanish. Above all, an Isthmus Canal must be constructed and there was a rising tide of feeling that the Caribbean Sea, in which Seward had vainly tried to arouse interest, must become a field for special American influence and effort. To hold the Canal, it would be necessary in the long run to have ports and naval stations in the West Indies; how could they be so easily acquired as by the annexation of Cuba?

\section{SPANISH WAR (1898)}

While Cleveland was President no headway could be made in that direction. When McKinley was inaugurated in March, 1897, he continued the policy of neutrality, but a strong pressure of men and party was put on him to adopt a more active policy. Several accidents, especially the destruction of the battleship Maine in the harbor of Havana, heightened the tension. April 11, 1898, McKinley sent to Congress a message to the effect that nothing could end the Cuban war except armed intervention. The main argument for such intervention was the interest of the United States; and McKinley's statement, 
though applied to the one question before him, sums up a general principle:

“ The present condition of affairs in Cuba is a constant menace to our peace and entails upon this Government an enormous expense. With such a conflict waged for years in an island so near us and with which our people have such trade and business relations; when the lives and liberty of our citizens are in constant danger and

Interference with American Interests. their property destroyed and themselves ruined; where our trading vessels are liable to seizure and are seized at our very door by ships of a foreign nation; the expeditions of filibustering that we are powerless to prevent altogether, and the irritating questions and entanglements thus arising - all these and others that I need not mention, with the resulting strained relations, are a constant menace to our peace and compel us to keep on a semi war footing with a nation with which we are at peace."

This was the basis upon which Congress virtually declared war on Spain, April 20,1898; but in the course of the discussion was added what is known as the Teller Resolution, which was a self-denying ordinance against the annexation of Cuba. This declaration added great weight to the idea that the United States ought not to annex other American territory. It disclaimed control over Cuba by the United States -

"That the United States hereby disclaims any disposition or intention to exercise sovereignty, jurisdiction, or control over said Island except for the pacification thereof, and asserts its determination, when that is accomplished, to leave the government and control of the Island to its people."

A confused notion that the Monroe Doctrine was somehow involved, is seen in a passage in a report made to the Senate in 1898:

"We can not consent upon any conditions that the depopulated portions of Cuba shall be recolonized by .Spain any more than she should be allowed to found a new colony in any part of this hemisphere or island thereof."

If annexation of Cuba were not the motive for war, what was the motive? First of all, to clear the remnant of Spanish power out of the Antilles. That power was much less arbitrary 
than Americans supposed, the insurrection was less widespread than Americans believed. At the last moment Spain was willing to reform Cuba in much the same way as after the first insurrection, but the government at Washington would none of it. Whatever else the public knew, or did not know, it was sure that it wanted to drive out the Spaniards.

This national determination led to a singular result. Porto Rico, which was almost undefended, was conquered by an American military force. The Porto Ricans had.not revolted and showed no serious discontent with Spanish rule; but the Americans were in no mood to go beyond the letter of their agreement and since Porto Rico was not mentioned in the Teller Resolution, they annexed it at the end of the war, action which has ever since served as an object lesson to Latin America. Cuba was speedily occupied and held for the benefit of the Cuban patriots whenever they should be properly organized.

At the same time the war spread in a direction hardly foreseen by Americans, Cubans, or Spaniards. An American fleet under Commander Dewey took possession of Manila Bay; supporting troops were sent out and they eventually captured Manila. A German fleet under Admiral Diedrichs for a time seemed inclined to dispute the American occupation. The native Filipinos objected, organized an army, and for two years made war on the American forces. In the treaty of peace, however, Spain had confirmed the loss of Cuba and Porto Rico, and surrendered the Philippine Islands and the little island of Guam. The Hawaiian Islands were also at last annexed by their own consent, and the United States took complete title to a portion of the Samoan group. Several small islands in the Pacific, - especially Wake and Midway, etc., which had been visited by American ships of war, were formally annexed.

These captures, made with so much quickness and ease, changed the international outlook of the United States; in the space of a twelvemonth she became a world power, with island possessions in the north and central Pacific Ocean; with a populous Asiatic archipelago ; with a protectorate and a colony in the West Indies. Toward the end of the war, when Spain seemed slow to accept the conqueror's terms, a suggestion was made that an American fleet would be dispatched to the Euro- 
pean coast of Spain. The hint was not lost on France and other European powers, which put a pressure on Spain to agree to the proposed treaty of cessions. It showed that the old Doctrine of Two Spheres which Olney had defended three years before was losing its vitality.

\section{AMERICAN POLICY IN ASIA (1885-1900)}

Within the new American empire thus established, as also within the outer world, a new spirit and a new policy at once appeared. Alaska, the Hawaiian Islands, and Porto Rico were virtually colonies of the United States, - not the old-fashioned sort of territories which were only waiting for a wave of immigration in order to become states, but colonies like those of France or Great Britain. The native population of Alaska could be ignored and seventeen years passed before the whites in Alaska received a regular territorial government. The Hawaiian Islands had a mixed population of natives, Japanese, and Europeans, with a small American-born population; and received a territorial government, in which the Japanese and the uneducated part of the born Hawaiians have no votes.

The status of the Philippines is a still sharper departure from the principles of self-government. These islands were made an Asiatic colony in the European sense. A body of eight million partially civilized and christianized natives was by unexpected conquest brought under the complete dominion of a nation very distant and different in language, race, and religion. Whatever the expectation of 'the United States, no stream of colonization has ever poured into the new acquisition. The climate and conditions attract no permanent immigrants.

The possession of these territories, and their organization under acts of Congress and Presidential proclamations made the United States a colonizing power with a foothold in Asia. Therefore, in 1900, the administration sent a contingent to join the Allies in their march up to Peking, to rescue the beleaguered diplomats. Inasmuch as most of the great European powers have interests and territory on the east coast of Asia, the United States thus became engaged in difficulties which have to be settled in the cabinets of Europe. The Doctrine of Two Spheres could be maintained in 1823, or even in 1895, when the United States had no possessions or immediate 
ambitions outside the continent of North America and the islands immediately adjoining. It lost its force when the United States occupied half a dozen points of vantage in the Pacific, including a group of islands with eight million people. It disappeared when military and diplomatic representatives of the United States took part with those of European nations in the affairs of Eastern Asia.

\section{AMERICAN POLICY IN AFRICA (1884-1906)}

In Africa, also, the United States showed a disposition to give up her old-fashioned isolation. Liberia has ever since 1847 been looked upon as under special American influence, and other nations have regularly let Liberia alone, and tacitly acted on the idea of paramount interest of the United States.

In the Congo region the United States took interest, partly because of some trade there, and partly because it gave an opportunity to protest against the slave trade and slavery. Hence representatives were sent to the general European Congress on Congo affairs in Berlin in 1884 and 1885. And they signed the final act of that Conference in behalf of the United States. A few weeks later Cleveland became President, and he declined to lay the treaty before the Senate, on the ground that ratification would cause-

"The United States [to] appear without reserve or qualification, as signatories to a joint international engagement imposing on the

No Joint Control of Africa. signers the conservation of the territorial integrity of distant regions where we have no establishedd interests or control. . . . holding that an engagement to share in the obligation of enforcing neutrality in the remote valley of the Congo would be an alliance whose responsibilities we are not in a position to assume, I abstain from asking the sanction of the Senate to that general act."

In Africa, as in Asia, the only general diplomacy was European diplomacy. Not only in the center of the continent, but on the Northern coast developed a state of tension, which finally drew the United States into a general European congress at Algeciras in 1906. 
The American Doctrine was a doctrine of peace, and so far as it was invoked in defense of the Spanish War, was out of place. The conquest of Porto Rico was in spirit opposed to Monroe's ideas, though in accord with the feeling of John Quincy Adams, Polk, and Seward. As a doctrine of peace, the American Doctrine appeared in the Hague Conference in 1899. While the proposed convention on peace was under discussion, an apparently harmless clause was introduced under which -

" The signatory Powers consider it their duty, if a serious dispute threatens to break out between two or more of them, to remind these latter that the Permanent Court is open to them."

Captain Mahan, one of the three American delegates, saw in this paragraph the possibility that some European powers would feel it a "duty" to "remind" the United States, in case that country should become involved in hostilities with a LatinAmerican neighbor. To cover this point a reservation was drawn up by the American delegates and accepted by the Hague Conference in the following terms:

"Nothing contained in this convention shall be so construed as to require the United States of America to depart from its traditional policy of not entering upon, interfering with, or entangling itself in the political questions or internal administration of any foreign state; nor shall anything contained in the said convention be so construed

Reservation of the Traditional Policy. as to require the relinquishment, by the United States of America, of its traditional attitude toward purely American questions."

The term "traditional attitude toward purely American questions" was understood by every member of the Conference to mean the American Doctrine; and this solemn reservation seems to assume that there is a definite body of principles, universally recognized, as to the relation of the United States to the rest of America. The two delegates who have written published accounts of this transaction do not own to any authority from the State Department to take so important a step ; but if Secretary Hay was not consulted by cable, he nevertheless cordially accepted the reservation, and it was included in the ratification of the Convention by the Senate. In the Second Hague Conference of 1907 the reservation was again 
introduced in a similar passage. The fact that there is a "traditional attitude toward purely American questions" is thus established by official authority. It remained to be seen how far the American definition of traditional attitude would be accepted by other parts of the world.

\section{WITHDRAWAL OF GREAT BRITAIN FROM THE CANAL (1900-1901)}

One of the most striking incidents of the Spanish War was the hearty goodwill and friendly offices of Great Britain; throughout the contest the English government, press, and people were decidedly on the American side; and when the Spaniards tried to delay the peace negotiations, Great Britain insisted on a treaty of peace which would be satisfactory to the United States. The impulse toward this state of mind was undoubtedly the sharp and hostile declarations of Cleveland and Olney in 1895, and the backing up of their policy by the American people. At this time England was in a state of "splendid isolation", without a European ally. It seemed a waste of the national energies to be quarreling with the United iStates over the control of a Canal which never would be built unless England abdicated from a share in its management. The great abilities of Secretary John Hay were now brought to bear. He became Secretary of State in 1898, and supervised the treaty with Spain. In 1899 he framed his successful doctrine of the Open Door in China; in 1900 he set himself the task of removing England from the coil of difficulties in the way of an Isthmian canal.

Several irritating things had happened on the Isthmus since the French company ceased its work in 1889. The English occupied Bluefields on the Nicaragua coast in 1894, but withdrew, and gave up all claims to that coast once for all, which cleared the road of one obstacle. In 1894 the French company was reorganized and began operations, not with any hope of completing the canal, but in order to put its work and claims in such shape as to justify a good price for them, if they came into the market.

Secretary Hay took the same ground of the need of exclusive control by the United States as almost every Secretary since Seward. When formal negotiations began in 1900 England showed a disposition to ask a price for withdrawing - such as 
the cession of ports in Alaska, - but adopted the better policy of a frank and clear giving up of all claim to a Canal. The socalled First Hay-Pauncefote Treaty of 1900 summed up the whole matter in a few lines :

"It is agreed that the canal may be constructed under the auspices of the Government of the United States, either directly at its own cost; or by gift or loan of money to individuals or corporations or through subscription to or purchase of stock or shares, and that, subject to the provisions of the present Convention, the said

Exclusive Rights of the United States. Government shall have and enjoy all the rights incident to such construction, as well as the exclusive right of providing for the regulation and management of the canal."

This was the whole treaty, except a set of rules for the neutralization of the Canal, founded on the Suez Canal Convention of 1888. The Senate objected that the treaty left indefinite the question whether the old Clayton-Bulwer Treaty was still in force, and therefore proposed amendments which were eventually accepted by Great Britain. The result was a second Hay-Pauncefote Treaty, closed in 1901, which in terms set forth that:

"The High Contracting Parties agree that the present Treaty shall supersede the afore-mentioned Convention of the 19th April, 1850."

On this basis, the right to build a Canal anywhere on the Isthmus was left, so far as Great Britain could leave it, in the hands of the United States. Two new obstacles now appeared: first, a rivalry between the Nicaragua and Panama routes; and second, a deadlock with Colombia, which was the owner of the Panama route.

\section{PREPARATIONS FOR AN AMERICAN CANAL (1899-1902)}

It was a natural supposition that any Latin-American country would be delighted to have an interoceanic canal constructed across its territory, which would put it on one of the world's greatest water highways. A canal would bring traffic to the ports, business to the merchants, and consequent taxes for the government. In so far as Nicaragua was concerned, there was no trouble; for in the contest for routes that govern- 
ment had always shown itself willing to make any concession necessary to secure a canal. In 1899, long before the HayPauncefote Treaty was out of the way, President McKinley appointed under act of Congress a board of skilled engineers, to determine "the most practicable and feasible route for such canal." The commission in 1900 reported in favor of the Nicaragua route, because the Panama company had control of the rival route, and would not sell out its work and concessions for any reasonable sum.

Between the lines could be read the belief of the engineers that the Panama route was far more desirable. Congress thereupon passed the Hepburn Act, directing the President to begin work on the Nicaragua route unless "within a reasonable time and upon reasonable terms" he could secure the Panama route. President Roosevelt was very doubtful whether a Nicaragua Canal would stand the earthquakes, and was heart and soul in favor of the Panama route. All the obstacles to that route were now removed except the consent of Colombia and the unworked and expiring franchises of the French company. At the suggestion of Secretary Hay, the Colombian authorities drafted a treaty, through the hand of their representative, Herran, by which Colombia agreed to the sale of the property of the canal company.

" The exclusive right for the term of one hundred years, renewable at the sole and absolute option of the United States, for periods

Exclusive Rights to the United States. of similar duration so long as the United States may desire, to excavate, construct, maintain, operate, control, and protect the Maritime Canal. . . . Colombia grants . . . the use and control . . . of a zone of territory along the route of the canal to be constructed five kilometers in width on either side. . . .

"The United States freely acknowledges and recognizes this sovereignty and disavows any intention to impair it in any way No Anneza- or to increase its territory at the expense of Colombia tion. or of any of the sister republics in Central or South America, but on the contrary, it desires to strengthen the power of the republics on this continent, and to promote, develop and maintain their prosperity and independence. ... .

" The United States shall have authority to protect and make secure the canal, ... . and to preserve order and discipline among Jurisdicthe laborers and other persons who may congregate tion. in that region, and to make and enforce such police 
and sanitary regulations as it may deem necessary to preserve order and public health thereon, and to protect navigation and commerce through and over said canal. . . .

"The canal, when constructed, and the entrance thereto shall be neutral in perpetuity, and shall be opened upon the terms provided for by Section I of Article three of, and in conformity with all the stipulations of, the treaty entered into by the Governments of the United States and Great Britain on November 18,

Effect of

Hay-

Paunce-

fote

Treaty. 1901."

It is necessary to cite the exact text of this document because it shows how moderate was the degree of control which the United States accepted over the canal line. For these privileges it agreed to pay $\$ 10,000,000$ in cash, and $\$ 250,000$ a year. This was the first time that such a money payment had been promised.

\section{CANAL TREATY WITH PANAMA (1902-1904)}

Under these circumstances the Senate ratified the treaty; but the Colombian Congress used its constitutional privilege of refusing ratification. This was a great disappointment to President Roosevelt, and the only reasons for refusal that could be obtained from Colombia were technical. It was believed that the real motive was a desire to wait a few months till the concession of the Panama Company could be annulled, so as to take over the property, and then sell it to the United States as an additional asset requiring additional payment.

So far nothing had occurred to give alarm to Colombia; but after the final rejection of the treaty in Bogota, a little revolution broke out in the city of Panama in 1903. It was the sort of thing which had happened before; several times American marines or jackies had been landed to protect the freedom of Isthmus transit, as authorized by the treaty of 1846 with Colombia. A mass meeting declared the State of Panama an independent republic on November 4. On November 6 Secretary Hay authorized the recognition of the new republic. The only distinct ground stated for this action was that President Roosevelt -

" Holds he is bound not merely by treaty obligations but by the interests of civilization to see that the peaceable traffic of the world 
across the Isthmus of Panama shall not longer be disturbed by a constant succession of unnecessary and wasteful civil wars."

The United States went back to a doctrine originally laid down by Secretary Cass in 1858:

" Sovereignty has its duties as well as its rights, and none of these local governments, even if administered with more regard to the just demands of other nations than they have been, would be permitted, in a spirit of Eastern isolation, to close these gates of intercourse on the great highways of the world, and justify the act by the pretension that these avenues of trade and travel belong to them, and that they choose to shut them, or, what is almost equivalent, to encumber them with such unjust regulations as would prevent their general use."

December 7, 1903, a treaty was submitted to the Senate with the new Republic of Panama, by which rights were conceded for the building of the canal under authority of the United States on terms about the same as those of the Colombian treaty. The canal strip was widened to ten miles, within which the United States was to exercise -

" All the rights, power, and authority . . . which the United States would possess and exercise if it were the sovereign of the territory."

The money payment was to be the same. Armed with this authority the United States arranged with the French company for the purchase of its property and privileges for $\$ 40,000,000$. As soon as possible, work began on the new construction; and in 1914 the Canal was opened to traffic.

THE UNITED STATES IN THE EYES OF SPANISH AMERICA (1903)

The dramatic turn by which Colombia was suddenly ousted from one of the most splendid points of vantage in the world startled both the people of the United States and of Latin America. The French government had never made any claims to territory or influence because of the concession to the French company; Great Britain was out of the difficulty altogether; no other power had the right or the desire to interfere. In fact, all the European powers within a short time followed the lead of the United States in recognizing the infant Republic of 
Panama as independent. To the people of the United States President Roosevelt rendered account in a special message dated January 4, 1904, in which he indignantly denied that he had arranged for or taken any responsibility for the Panama revolution. There has never been reason to doubt that statement; though both the President and Secretary Hay evidently thought such a rising was likely. The three main reasons that he stated for his decided action are as follows:

"That our wise and patriotic ancestors, with all their dread of entangling alliances, would have entered into a treaty with New Granada solely or even primarily for the purpose of enabling that remnant of the original Republic of Colombia, then resolved into the States of New Granada, Venezuela, and Ecuador, to continue from

Rights under the Treaty of 1846 . Bogota to rule over the Isthmus of Panama, is a conception that would in itself be incredible, even if the contrary did not clearly appear... . . The great design of the article was to assure the dedication of the Isthmus to the purposes of free and unobstructed interoceanic transit, the consummation of which would be found in an interoceanic canal. To the accomplishment of this object the Government of the United States had for years directed its diplomacy. ... .

"This recognition was, in the second place, further justified by the highest considerations of our national interests and safety. In all the range of our international relations, I do not hesitate to affirm that there is nothing of greater or more pressing importance than the construction of an

National

Interests and Safety interoceanic canal. ... In the light of our present situation, the establishment of easy and speedy communication by sea between the Atlantic and the Pacific presents itself not simply as something to be desired, but as an object to be positively and promptly attained. Reasons of convenience have been superseded by reasons of vital necessity, which do not admit of indefinite delays. . . .

"In the third place, I confidently maintain that the recognition of the Republic of Panama was an act justified by the interests of collective civilization. If ever a government could be said to have received a mandate from civilization to effect an object the accomplishment of which was

Interests of

Collective demanded by the interest of mankind, the United States holds that position with regard to the interoceanic canal.... That our position as the mandatory of civilization has been by no means misconceived is shown by the promptitude with which the powers have, one after another, followed our lead in recognizing Panama as an independent State." 
The essence of this defense is that the United States of America represents a higher kind of human interest than the Latin-American states; and that in case of a clash of interests those of the United States are paramount. Elsewhere, Roosevelt spoke of the right of international expropriation. $\mathrm{He}$ looked upon himself as a defender of the needs of the highest civilization against lower types of society and political organization. Throughout all his papers and discussions of the subject runs a note of rancor toward a state which tried to put its unrivalled geographical situation up at auction. The situation is that of a real estate owner who needs a right of way and finds that his neighbor demands an exorbitant figure. In private relations, the wealthy purchaser must pay the price or go without. In contests between nations, the stronger has often ousted the weaker out of an advantage which the aggressor would not itself give up except as the penalty of an unsuccessful war.

The United States was rather hampered in her insistence on her own greater need as against the smaller advantage of a neighbor, for just at this time we refused to transfer a few ports on the Alaskan coast to Canada, that would have been of great advantage to the Canadians and would have little interfered with our interests.

'To Roosevelt's mind the question was not that of the interest of a great power against a weak one, but of all other nations against one selfish people - the nation who could not build a canal and would not suffer another to build it. Roosevelt felt that the government of Colombia could not assert sovereign rights on a strip of land which was so signifcant to mankind. He felt that he was acting for all nations against a small, selfish, and badly governed nation, which had not the full privileges of a state in the international sense.

Colombia took the transaction very hard; for not only the ready millions disappeared, but also the territory which surrounded and commanded the canal, and the whole state of Panama. The new independent Panama was visibly a puppet state, the satellite of the United States, a means of getting territorial control of the Canal without too much offending the susceptibilities of mankind. Twelve years later, Colombia was still furious over the episode, and the other Latin-American powers sympathized with her feeling of wrong and danger. 


\section{THE NEW AMERICAN SITUATION (1903)}

What was the place of the American Doctrine in the great changes in the American world from 1898 to 1903, which have here been sketched? The original Monroe Doctrine could hardly be applied at all. Here was no danger of "intervention," because the only cases of intervention were in Cuba and Panama, and the United States was responsible for both. The principle of "colonization". could hardly be allowed to mean the right of the United States to create colonies in the West Indies or the Pacific. If the "political system" of Europe meant the use of superior force from without to compel American states to do what was disagreeable to them, then both Spain and Colombia had reason to claim that the Ameriean "political system" had been applied to their hurt. The Doctrine of the Two Spheres was weakened beyond repair. The status of the United States as the watchful defender of the interests of other American states was much disturbed, both by the annexation of Porto Rico and by the virtual annexation of the Canal Zone. The one piece of national self-restraint had been the refusal to annex Cuba, by honorable adherence to the Teller Resolution on that subject. .

No, the doctrine that was applied in 1903 to the status of England, the status of Spain, and the status of the Isthmus Powers was nothing other than that of "Paramount Interest." It was inconvenient and dangerous for the United States that the near-by island of Cuba should be paralyzed by civil war; and therefore the armies and navies of the Great Republic were called in, to take that magnificent province away from Spain. In this process Porto Rico was a kind of by-product, which dropped so aptly into the lap of the United States that it would have been an impiety to question the wisdom of Providence. For the convenience and safety of American commerce, and for the extension of American national influence, it was necessary to take the Philippine Islands: Spain could not make them the center of an eastern commerce, which the United States expected to do.

To oust Great Britain from a share in the Isthmian Canal was the necessary step to a comfortable approach to the Canal. England was in a situation where it was better to give up something than to incur the hostile feeling of the United States. 
The fundamental contention of this Government that England had canals enough and must give other nations an opportunity to enjoy their control, was sound and sensible. The United States also was a great commercial nation with ambitions to extend trade and influence, not only in the Americas but in the Pacific and Asia; and England certainly had no title or presumptive right (outside of the Clayton-Bulwer Treaty) which would justify standing in the way.

In the Isthmus case, it was perfectly clear that the thing desired was far more important to the United States than to anybody else; and that it would add to rather than subtract from the wealth and political power of the state through which the canal was to be constructed. For engineering reasons the Niearagua route was not looked upon by the experts or by the President as a real rival. They all felt in their hearts that the Panama route was the natural world route; and that if the United States put its capital into the Nicaragua Canal, somebody would complete the Panama Canal without the United States taking part.

The difficulty in this point of view is obviously that it denies equal sovereignty to the American powers; that it puts Colombia into a second class of nations; that it gives warning to all Latin America that second-class powers must in case of need give way to first-class powers. Thus the three main relations with Latin America between 1898 and 1903, - the Cuban War, the Hay-Pauncefote Treaty, and the possession of the Canal Zone, - all pointed to the ignoring of the old-fashioned Monroe Doctrine and even the American Doctrine as known to Seward and Fish and Blaine; and the substitution of a new political system in America in which the United States should be the leading figure. 


\section{Chapter XIV}

\section{THE ROOSEVELT DOCTRINE AND ITS SUCCESSORS 1901-1915}

\section{THE MONROE DOCTRINE ALWAYS WITH US}

The Cuban war and the annexation of the Canal Zone have had great effect upon the American Doctrine, but at the time details were quickly settled. In 1902 the American troops were withdrawn from Cuba, and a nominally independent republic was then set up as an addition to the family of nations, which could not be restored to Spain, nor detached from its close relation with the United States, by anything short of European invasion. In the same way the Canal controversy was at an end; not only England but all the other powers of the world accepted the transaction and recognized the so-called state of Panama. The Hay-Varilla canal treaty was ratified once for all in February, 1904, and a few days earlier President Roosevelt pointedly said to Congress :

"The question actually before this Government is not that of the recognition of Panama as an independent republic. That is already an accomplished fact. The question, and the only question, is whether or not we shall build an Isthmian canal."

The elimination of these two vexing questions only seemed to leave room for another set of perplexities and dangers. From 1901 to 1915 there was a succession of incidents which showed that however satisfied the United States might be with her policy, neither Latin America nor Europe understood or accepted the findings of the United States with regard to her own interests, powers, or intentions. The name of Monroe confused the whole issue, for no foreign statesman could be brought to believe that Monroe, Polk, Buchanan, Grant, Cleveland, and McKinley 
all wanted the same thing, or meant the same thing when they described their policies. To the people of the country, to the experienced statesmen of Latin America and to the world at large, the policy of the United States was a jumble in which benevolence, self-interest, defense, and desire for more territory, all had a part.

The Monroe Doctrine, and its development into an American Doctrine, promised peace, and yet there was war in America. The United States gave a kind of pledge for the good behavior of the Latin-American States, notwithstanding which they behaved ill. In 1902 Germany, England, and Italy made a fair test of the question whether the American Doctrine stood in the way of a military expedition against the Latin-American states, if no conquests were intended. This put the State Department on its mettle to preserve the influence of the United States against foreign aggressions, and at the same time to avoid direct responsibility for states which had given cause of offense to extra-American powers.

In this juncture arose Theodore Roosevelt, aided by John Hay, and, after Hay's death in 1905, by Elihu Root, as Secretaries of State. All three were men of large vision, strong national spirit, and a genuine desire to help their Latin-American brethren upward. They were men both of words and of action. Their policies will be considered later in this volume, but their words must be noted here, because they tried hard to think out the complicated subject and to phrase statements which might be accepted as an official and permanent doctrine of foreign policy. Roosevelt wrote easily and much, and was so fond of stating moral principles, that he has been accused of "inventing the Ten Commandments." His whole point of view was to do things and at the same time to make clear to the world his reasons for doing them. He was ambitious to codify the American Doctrine, to exclude everything that had found its way into the mass of official statements but was outworn or out of keeping. At the same time, he tried to employ phrases and ideas that would cover the conditions of America as he found them. His views are not contained in any one state paper; but some significant extracts, especially from his messages from 1901 to 1905 , can be arranged in an order which will bring out his favorite principles. 
TEXT OF THE ROOSEVELT DOCTRINE (1901-1906)

"That our rights and interests are deeply concerned in the maintenance of the Doctrine is so clear as hardly to need argument. This is especially true in view of the construction of the Panama Canal. As a mere matter of self-defense we must exercise a close watch over the approaches to this canal; and this means that we

Permanence of the Monroe Doctrine. must be thoroughly alive to our interests in the Caribbean Sea."

"We would interfere with them only in the last resort, and then only if it became evident that their inability or unwillingness to do justice at home and abroad had violated the rights of the United States or had invited foreign aggression to the detriment of the entire body

Interposition by the U. S. of American nations."

"There are certain essential points which must never be forgotten as regards the Monroe Doctrine. In the first place we must as a nation make it evident that we do not intend to treat it in any shape or way as an excuse for aggrandizement on our part at the expense of the republics to the south. We must recognize the fact that

No Aggrandizement of the U. S. in some South American countries there has been much suspicion lest we should interpret the Monroe Doctrine as in some way inimical to their interests, and we must try to convince all the other nations of this continent once and for all that no just and orderly government has anything to fear from us. . . . If all of the republics to the south of us will only grow as those to which I allude have already grown, all need for us to be the especial champions of the Doctrine will disappear, for no stable and growing American Republic wishes to see some great non-American military power acquire territory in its neighborhood."

"This doctrine has nothing to do with the commercial relations of any American power, save that it in truth allows each of them to form such as it desires. In other words, it is really a guaranty of the commercial independence of the Americas. We do not ask under this

Guaranty of Commercial Independence. doctrine for any exclusive commercial dealings with any other American state. We do not guarantee any state against punishment if it misconducts itself, provided that punishment does not take the form of the acquisition of territory by any

Protection non-American power."

of Territory.

"Our attitude in Cuba is a sufficient guaranty of our own good faith. We have not the slightest desire to secure any territory at the expense of any of our neighbors. We wish to 
work with them hand in hand, so that all of us may be uplifted together, and we rejoice over the good fortune of any Sympathy of them, we gladly hail their material prosperity and with Latin political stability, and are concerned and alarmed if America. any of them fall into industrial or political chaos. We do not wish to see any Old World military power grow up on this continent, or to be compelled to become a military power ourselves. The peoples of the Americas can prosper best if left to work out their own salvation in their own way."

"The Monroe Doctrine should be the cardinal feature of the foreign policy of all the nations of the two Americas, as it is of the Peace in United States. ... The Monroe Doctrine is a America. declaration that there must be no territorial aggrandizement by any non-American power at the expense of any American power on American soil. It is in no wise intended as hostile to any nation in the Old World. Still less is it intended to give cover to any aggression by one New World power at the expense of any other. It is simply a step, and a long step, toward assuring the universal peace of the world by securing the possibility of permanent peace on this hemisphere. During the past century other influences have established the permanence and independence of the smaller states of Europe. Through the Monroe Doctrine we hope to be able to safeguard like independence and secure like permanence for the lesser among the New World nations."

"It is not true that the United States feels any land hunger or entertains any projects as regards the other nations of the West-

The U. S. as an International Policeman. ern Hemisphere save such as are for their welfare. ... If a nation shows that it knows how to act with reasonable efficiency and decency in social and political matters, if it keeps order and pays its obligations, it need fear no interference from the United States. Chronir. wrongdoing, or an impotence which results in a general loosening of the ties of civilized society, may in America, as elsewhere, ultimately require intervention by some civilized nation, and in the Western Hemisphere the adherence of the United States to the Monroe Doctrine may force the United States, however reluctantly, in flagrant cases of such wrengdoing or impotence, to the exercise of an international police power."

"It is not merely unwise, it is contemptible, for a nation, as for an individual, to use high-sounding language to proclaim its Use of purposes, or to take positions which are ridiculous if Force. unsupported by potential force, and then to refuse to provide this force. . . . It is our duty to remember that a nation has no more right to do injustice to another nation, strong or weak, 
than an individual has to do injustice to another individual; that the same moral law applies in one case as in the other. But we must also remember that it is as much the duty of the Nation to guard its own rights and its own interests as it is the duty of the individual so to do."

"The Monroe Doctrine should be treated as the cardinal feature of American foreign policy; but it would be worse than idle to assert it unless we intended to back it up, and it can be backed up only by a thoroughly good navy.

Support by A good navy is not a provocative of war. It is the surest guaranty of peace."

"In asserting the Monroe Doctrine, in taking such steps as we have taken in regard to Cuba, Venezuela, and Panama, and in endeavoring to circumscribe the theater of war in the Far East, and to secure the open door in China, we have acted in our own interest as well as in the

Intervention Elsewhere. interest of humanity at large. There are, however, cases in which, while our own interests are not greatly involved, strong appeal is made to our sympathies. . . . In extreme cases action may be justifiable and proper. What form the action shall take must depend upon the circumstances of the case; that is, upon the degree of the atrocity and upon our power to remedy it. The cases in which we could interfere by force of arms as we interfered to put a stop to intolerable conditions in Cuba are necessarily very few. . . . It is inevitable that such a nation should desire eagerly to give expression to its horror on an occasion like that of the massacre of the

Sympathy with Europe and Asia. Jews in Kishenef, or when it witnesses such systematic and longextended cruelty and oppression as the cruelty and oppression of which the Armenians have been the victims, and which have won for them the indignant pity of the civilized world."

\section{PAN-AMERICAN CONGRESSES (1901-1915)}

An evidence of the genuine desire of the United States to come into closer and friendlier relations with the other American powers, was the successful revival of the idea of a formal meeting of representatives of the various countries. The Washington Pan-American Conference of 1889-1890 left an agreeable impression; and in 1900 President McKinley, through Secretary Hay, suggested an "International American Conference", which was eventually called by the Mexican Government to meet in the city of Mexico in 1901. All the American states 
sent delegates, and the Conference agreed upon a surprising number of projects, though the representation of the United States in every case gave notice that no treaty went into effect unless ratified by the Senate.

It fell to President Roosevelt to propose instructions to the American delegates. In friendly tones he warned them that the United States was not prepared to take much responsibility for her neighbors. He spoke of -

"The safety and permanence of the political system which underlies their and our existence as nations. . . . It is not ... opportune for the delegates from the United States to assume the part of leadership in the conference."

The Conference, in behalf of all its members, voted to adhere to the Hague Conventions that had been made three years before. It also drew up a treaty of arbitration for pecuniary claims, by which the signatories agreed to submit claims which could not be otherwise settled to the Hague Tribunal. It recommended an international railway to run from Mexico to the Argentine, a project first brought forward in the Pan-American Congress at Washington in 1890. A Customs Congress was proposed to simplify the formalities and adopt a common nomenclature. There were also resolutions for unifying the treatment of vessels and merchants in the various countries; for setting up an international sanitary policy; for calling a coffee commission; for creating an international archæological commission ; for founding a Pan-American bank. The Congress congratulated Cuba on becoming a republic, and approved the construction of an Isthmus Canal by the United States. One of the few acts of the Congress which bear upon political relations was a resolution of gratitude to Carlos Calvo, whose chief service was the so-called Calvo Doctrine on the independence of American States.

The "Third International Conference of American States" was called by the Conference of 1901 and met at Rio de Janeiro in August, 1906. Panama and Cuba were received as new and equal members. Two of the general treaties drawn up there one on pecuniary claims, and one on naturalized citizens - were eventually ratified by the United States. The most striking incident of the Conference was the speech of Secretary Root, who came down on a special mission to express the sentiments of President Roosevelt on behalf of the United States. 
"We deem the independence and equal rights of the smallest and weakest member of the family of nations entitled to as much respect as those of the greatest empire, and we deem the observance of that respect the chief guaranty of the weak against the oppression of the strong. We neither claim nor desire any rights, or privileges,

Equal Rights of American States. or powers that we do not freely concede to every American Republic. We wish to increase our prosperity, to extend our trade, to grow in wealth, in wisdom, and in spirit, but our conception of the true way to accomplish this is not to pull down others and profit by their ruin, but to help all friends to a common prosperity and a common growth, that we may all become greater and stronger together.

“. . . Let us unite in creating and maintaining and making effective an all-American public opinion, whose power shall influence international conduct and prevent international wrong and narrow the causes of war, and forever preserve our free lands from the burden of such arma-

All-American Public Opinion. ments as are massed behind the frontiers of Europe, and bring us ever nearer to the perfection of ordered liberty."

This conference was more business-like than that in Mexico, although it undertook too many projects at once. It recommended to the approaching Second Hague Conference to go into the question of the collection of public debts, commonly called the Drago Doctrine, and provided for a fourth Conference. So far as the relations of the United States are concerned, the chief service of the Conference was the visit of Root to South America with his messages of sympathy and his promises that the United States would keep hands off.

The Fourth Conference met at Buenos Ayres in 1910, and the twenty-one American Republics except Bolivia were all represented. Beyond a resolution for a system of arbitration of pecuniary damages, the Conference moved in the familiar lines by suggesting uniform copyright and trade-mark laws, and by urging ambitious plans for an international railroad and bank, which somehow have never got beyond the paper stage.

Some subsidiary conferences, as for instance that on sanitary improvements, met from time to time; and in 1908 a Scientific Congress was held in Santiago, Chile. Another was called in Washington for 1915. All the Latin-American States were admitted to the Hague Conference in 1907, and thus presented a serious problem because of the number of small and weak states 
which felt that they were entitled to take part in decisions of great moment by a majority vote of nations. The main result of these three Congresses has been summed up by a LatinAmerican publicist as follows :

"Pan-Americanism counterbalances Pan-Saxonism, Pan-Latinism, and Spanish-Americanism, in the sense that both the United States and the Latin states of America feel themselves more closely bound to each other than to the other countries of their same respective origins."

\section{VENEZUELA CONTROVERSY (1902-1903)}

Venezuela had hardly come to a settlement with Great Britain on the boundary question by the arbitration of 1899 , before the two countries were involved in another difficulty over the treatment of British subjects and their property. The British Government, July 29, 1902, served notice upon the Venezuelan government that in case Venezuela should fail to -

"Promptly pay to the injured parties full compensation wherever satisfactory evidence has been furnished to His Majesty's Government that such is justly due, His Majesty's Government will take such steps as may be necessary to obtain the reparation which they are entitled to demand from the Venezuelan Government in these cases."

The Venezuelans had some apparently well-founded grievances against the British government which they looked upon as a kind of offset. Germany also had a batch of claims against Venezuela, and on December 7, 1902, put in a blanket demand for the settlement of the whole bill, on the basis figured out by the Germans. Venezuela behaved badly all the way through, refusing to agree upon any common tribunal, and attempting to set up an ex parte Venezuelan commission, which was to make the final decision whether claims were valid, and to pay for them in bonds of doubtful value. The United States, Spain, Netherlands, and Italy joined in protesting; but the Venezuelans fell back on two points which, as we shall see, have been elaborated by the jurist, Calvo: (1) that foreigners could not claim a more favorable status than native Venezuelans; (2) that diplomacy was not to be used to secure the settlement of foreign claims. 
The result was a document dated December 7, 1902, in which Germany demanded several hundred thousand dollars for damages suffered in the recent civil wars of Venezuela and for other losses. The two governments therefore agreed upon a policy of "reprisals", which would include a "pacific blockade" and were joined by Italy. The blockade was duly proclaimed; some Venezuelan vessels of war were seized and the Germans bombarded Puerto Cabello, and shelled a Venezuelan fort. Venezuela yielded and consented that the claims should be decided by the Hague Tribunal, which needed an opportunity to show its usefulness.

The United States took an honorable part in persuading the parties to agree to this arbitration. Before the Court a new issue appeared. Were the three powers which had joined in the military demonstration to come in for payment ahead of other powers, such as France, which had good claims and had reached an agreement with Venezuela? The Court on rather technical grounds held that the powers which had intervened were entitled to a priority in the settlement of their claims. Thus the controversy was closed, but its effects were lasting. In spite of the arguments of Olney and Cleveland with regard to the relations of Great Britain to Latin America, the English were actually intervening with armed force and were taking a part in attacking the ships and defenses of Venezuela, though without occupying any territory.

\section{SANTO DOMINGO (1905-1915)}

The care with which the European fleets forbore to land troops in Venezuela was not due to any weak-minded sympathy with a derelict power, but to a direct promise made by Germany. What would have happened if the Venezuelans had still refused to take any steps toward settling up the bill for damages which had been presented? Plainly the next step would be an intervention that would hurt; and that would be directly opposed to the intent of the American Doctrine. A few months later very similar trouble arose in the Republic of Santo Domingo ; and in 1905 President Roosevelt took the responsibility of negotiating a treaty with the Dominican government by which as a temporary arrangement Americans were to take charge of the custom-house. From one point of view this was a carrying 
out of the American Doctrine, by preventing European powers from seizing ports and custom-houses. On the other side, Roosevelt's action created something very like a protectorate. The President was non-committal on the important point whether this was a necessary defense of the American Doctrine, but dwelt on the immediate danger of occupation by other persons.

"It is not of the slightest consequence whether we grant the aid needed by Santo Domingo as an incident to the wise develop$\begin{array}{ll}\text { Danger of } & \text { ment of the Monroe Doctrine, or because we regard } \\ \text { European } & \text { the case of Santo Domingo as standing wholly by itself, } \\ \text { Interven- } & \text { and to be treated as such, and not on general prin- } \\ \text { tion. } & \text { ciples or with reference to the Monroe Doctrine. The }\end{array}$ important point is to give the needed aid. . . . There was imminent danger of foreign intervention. The previous rulers of Santo Domingo had recklessly incurred debts, and owing to her internal disorders she had ceased to be able to provide means of paying the debts. The patience of her foreign creditors had become exhausted, and at least two foreign nations were on the point of intervention, and were only prevented from intervening by the unofficial assurance of this Government that it would itself strive to help Santo Domingo in her hour of need. In the case of one of these nations, only the actual opening of negotiations to this end by our Government prevented the seizure of territory in Santo Domingo by a European power."

For two years Santo Domingo was administered under this agreement, which had behind it in the United States only the official signature of the Secretary of State and of the President. A few such "agreements" had at various times been made by authority of the President on international matters of little moment. To send down what were practically Federal officials to collect, bank, and apply the customs revenue of a nominally independent state went beyond any responsibility up to that time assumed by the President, and made a doubtful precedent.

Besides the Dominican and American authorities there was a third unofficial party to these transactions. This was the group of bankers in New York who were creditors or represented creditors of the island republic. The prime motive of the arrangement was to prevent a descent on a Latin-American state by a European state; the Dominican pcople were benefited by peace and order in their revenue; but the bankers 
had also a direct personal interest in the making and continuing of financial control. The system has stood the test of ten years' experience and is now the accepted policy of the State Department.

In connection with this transaction, President Roosevelt put into form a new version of the American Doctrine as applied to debtor and delinquent states, which has stood the test of the succeeding years, and appears to be sanctioned by the State Department.

"Moreover we must make it evident that we do not intend to permit the Monroe Doctrine to be used by any nation on this Continent as a shield to protect it from the consequences of its own misdeeds against foreign nations. If a republic to the south of us commits a tort against

No Seizure of Territory for Debt. a foreign nation, such as an outrage against a citizen of that nation, then the Monroe Doctrine does not force us to interfere to prevent punishment of the tort, save to see that the punishment does not assume the form of territorial occupation in any shape. The case is more difficult when it refers to a contractual obligation. ... On the one hand, this country would certainly decline to go to war to prevent a foreign government from collecting a just debt; on the other hand, it is very inadvisable to permit any foreign power to take possession, even temporarily, of the custom-houses of an American Republic in order to enforce the payment of its obligations ; for such temporary occupation might turn into a permanent occupation. The

No Temporary Occupation. only escape from these alternatives may at any time be that we must ourselves undertake to bring about some arrangement by which so much as possible of a just obligation shall be paid."

\section{THE TAFT DOCTRINE (1909-1913)}

A novelty in Roosevelt's policy and statements was his sound and practical decision that the United States could not protect a Latin-American state against the just resentment of a foreign nation, provided the acts of the foreign nation did not extend to taking possession of American territory. Another obvious principle was the right of the United States in the last resort to avoid such a seizure, by treating the offending Latin-American power as a bankrupt and putting in a United States official as a kind of receiver.

This latter policy President Taft followed out through his 
administration. The State Department was conducted by Secretary Knox, a skilled lawyer whose conception of his place was that he was employed by the United States to represent her material interests. His dispatches were substantially briefs, setting forth his case; and it was not his business to furnish points for the other side. As an experienced corporation lawyer, in close association with capitalists, he felt the necessityx.that the State Department should push American business interests. The resulting "dollar diplomacy" caused an uproar when it was applied in China, and was very repugnant to the Latin-American states. Nicaragua was practically administered by the United States. Secretary Root, a man of broad sympathies, as we have seen, visited .South America, where he was enthusiastically received by a people who are always affected by high courtesy and eloquence. Knox was almost inaccessible even to many American diplomats, and he showeu a disregard of the wishes and even of the rights of our neighbors, which repelled them.

Though President Taft's policy was forbidding, his words were full of American brotherhood. In his first message (1909), he intimated that the country was overstocked on Monroe Doctrines, and that he would not add to them.

"The Pan-American policy of this Government has long been fixed in its principles and remains unchanged. With the changed

Enforcement of Obligations. circumstances of the United States and of the Republics to the south of us, most of which have great natural resources, stable government and progressive ideals, the apprehension which gave rise to the Monroe Doctrine may be said to have nearly disappeared, and neither the doctrine as it exists nor any other doctrine of American policy should be permitted to operate for the perpetuation of irresponsible government, the escape of just obligations, or the insidious allegation of dominating ambitions on the part of the United States.

"Beside the fundamental doctrines of our Pan-American policy there have grown up a realization of political interests, community Common of institutions and ideals, and a flourishing commerce. Interests. All these bonds will be greatly strengthened as time goes on and increased facilities, such as the great bank soon to be established in Latin America, supply the means for building up the colossal intercontinental commerce of the future."

Nevertheless Taft pushed hard to acquire control of Nicaragua and Honduras, and at the other end of the line carried the 
influence of the United States into Europe by putting an end to a treaty.with Russia in 1911, because Americans of Jewish descent who visited Russia found that their passports were not respected.

A new variation of the American Doctrine was suggested by a supposed effort of Japan in 1912 to get control of territory on Magdalena Bay, in the Mexican territory of Southern California. The attention of Congress was called to it and Secretary Knox denied that either the Japanese government or any Japanese company had bought land on Magdalena Bay. Senator Lodge, whose interest in this subject had been shown in the controversy of 1895 , felt sure that the Japanese had designs on Mexican territory with a view of getting a permanent footing, and he introduced a resolution into the Senate which was adopted.

" Resolved, That when any harbor or other place in the American continents is so situated that the occupation thereof for naval or military purposes might threaten the communications or the safety of the United States, the Government of the United States could not see without grave concern the possession of such harbor or other place by any corporation or association which has such a rela-

No New

Foreign

Naval Sta-

tions in

America. tion to another Government, not American, as to give that Government practical power or control for naval or military purposes."

Thereby the Senate, as far as it had authority, added the Asiatic to the European powers in the list of those which must not interfere with the Latin-American states or introduce their political system.

\section{THE ROOT DOCTRINE (1914)}

As Secretary of State, Root made no notable statements which were not based upon President Roosevelt's principles; but when out of office, he became a kind of independent sage. In an address before the American Society of International Law, April 14, 1914, he made a careful survey of the history and meaning of the American Doctrine, which is much weakened by his unwillingness to admit the alteration of circumstances since 1823. 
"We frequently see statements that the doctrine has been changed or enlarged; that there is a new or different doctrine

No Change

in the

Monroe

Doctrine. since Monroe's time. They are mistaken. There has been no change. One apparent extension of the statement of Monroe was made by President Polk. ... All assertions to the contrary notwithstanding, there has been no other change or enlargement of the Monroe Doctrine since it was first promulgated. It must be remembered that not everything said or written by Secretaries of State or even by Presidents constitutes a national policy or can enlarge or modify or diminish a national policy."

This dictum might be challenged, but it does not interfere with the logical force of the general summary of the Doctrine which follows :

"It is the substance of the thing to which the nation holds and that is and always has been that the safety of the United Safety of States demands that American territory shall remain $\checkmark$ the U. S.

American.

"The Monroe Doctrine does not assert or imply or involve any right on the part of the United States to impair or control the independent sovereignty of any American state. ... The declaration of Monroe was that the rights and interests of the United States were involved in maintaining a condition, and the condition to be maintained was the independence of all the American countries. ... .

"The United States would have had the right against every other American state to object to acts which the United States

Rights

Irrespective of the

Monroe

Doctrine. might deem injurious to its peace and safety just as it had the right to object to such acts as against any European Power and just as all European and American Powers have the right to object to such acts as against each other. All these rights which the United States would have had as against other American states it has now. They are not in the slightest degree affected by the Monroe Doctrine. They exist now just as they would have existed if there had been no Monroe Doctrine. They are neither greater nor less because of that doctrine. They are not rights of superiority, they are rights of equality. They are the rights which all equal independent states have as against each other. And they cover the whole range of peace and war.

"It happens, however, that the United States is very much bigger and more powerful than most of the other American republics. And when a very great and powerful state makes demands 
upon a very small and weak state it is difficult to avoid a feeling that there is an assumption of superior authority involved in the assertion of superior power, even though the demand be based solely upon the right of equal against equal. An examination of the various controversies

Superior

Authority of the U.S. which the United States has had with other American Powers will disclose the fact that in every case the rights asserted were rights not of superiority but of equality. . . .

"As the Monroe Doctrine neither asserts nor involves any right of control by the United States over any American nation, it imposes upon the United States no duty towards European Powers to exercise such a control. It does not call upon the United States to collect debts or Duty of the

U. S. to Europe. coerce conduct or redress wrongs or revenge injuries.

"Since the Monroe Doctrine is a declaration based upon this nation's right of self-protection, it cannot be transmuted into a joint or common declaration by American states or any number of them. If Chile or Argentina or Brazil were to contribute the weight of her influence toward a

No Joint Declarations. similar end, the right upon which that nation would rest its declaration would be its own safety, not the safety of the United States. ...

"The building of the Panama Canal greatly accentuates the practical necessity of the Monroe Doctrine as it applies to all the territory surrounding the Caribbean or near the Bay of Panama. The plainest lessons of history and the universal judgment of all responsible students of

Effect of the Panama Canal. the subject concur in teaching that the potential command of the route to and from the Canal must rest with the United States and that the vital interests of the nation forbid that such command shall pass into other hands. Certainly no nation which has aćquiesced in the British occupation of Egypt will dispute this proposition. Undoubtedly as one passes to the south and the distance from the Caribbean increases, the necessity of maintaining the rule of Monroe becomes less immediate and apparent. But who is competent to draw the line? . . .

"A false conception of what the Monroe Doctrine is, of what it demands and what it justifies, of its scope and of its limits, has invaded the public press and affected public opinion within the past few years. Grandiose schemes of national expansion invoke the Monroe Doctrine. Interested motives to compel Central or South American

False Conceptions of the Monroe Doctrine. countries to do or refrain from doing something by which individual Americans may profit invoke the Monroe Doctrine. Clamors for national glory from minds too shallow to grasp at the same 
time a sense of national duty invoke the Monroe Doctrine. The intolerance which demands that control over the conduct and the opinions of other peoples which is the essence of tyranny invokes the Monroe Doctrine. Thoughtless people who see no difference between lawful right and physical power assume that the Monroe Doctrine is warrant for interference in the internal affairs of all weaker nations in the New World. Against this supposititious doctrine, many protests both in the United States and in South America have been made, and justly made. To the real Monroe Doctrine these protests have no application."

Root's Doctrine does not cover the whole ground, nor does it explain or justify the various steps taken by the United States in the direction of coercing or weakening other American countries. It may stand as the last word spoken by an expert in international law and a trained American statesman. Its spirit comes nearer than any similar systematic presentation of the Doctrine to a recognition of the duties of the United States. Nevertheless, the accuracy of the Root Doctrine must be tested by the actual relations of the United States to the rest of America.

\section{THE WILSON DOCTRINE (1913-1915)}

President Wilson had but one undisturbed year in which to develop a general American policy ; for the coming of the European War in 1914 dwarfed all foreign relations which were not associated with that crisis. While expressing good-will and sympathy with the Latin-American powers, he continued Roosevelt's and Taft's policy of making protectorates out of LatinAmerican states. This drew our American neighbors no nearer than before, either to the doctrine or the practices of the United States; and there was thrown upon him the intolerable weight of a problem in Mexico, which taxed the patience and wisdom of the Government.

By several public utterances President Wilson essayed to reasure the Latin-Americans and also, perhaps, to restrain his countrymen. March 11, 1913, a week after his inauguration, he issued a public statement of which the following extracts show the spirit.

"I earnestly desire the most cordial understanding and coöperation between the peoples and leaders of America. ... . Co- 
operation is possible only when supported at every turn by the orderly processes of just government based upon law, not upon arbitrary or irregular force. We hold ... that just government rests always upon the consent of the governed and that there can be no freedom without

Orderly

Government

Essential. order based upon law and upon the public conscience and approval. . . .

"We shall lend our influence of every kind to the realization of these principles in fact and practice, knowing that disorder, personal intrigue, and defiance of constitutional rights weaken and discredit government and injure none so much as the people who are unfortunate enough to Preference for Orderly have their common life and their common affairs so tainted and disturbed. ... We are the friends of peace. . . . As friends, therefore, we shall prefer those who act in the interests of peace and honor, who protect private rights, and respect the restraints of constitutional provisions. . . .

" The United States has nothing to seek in Central and South America except the lasting interests of the peoples of the two continents, the security of governments intended for the people and for no special group or interest, and the

Interests of the U. S. development of personal and trade relationships between the two continents which shall redound to the profit and advantage of both, and interfere with the rights and liberties of neither."

These convictions were linked into a more elaborate form in a speech made at Mobile, October 27, 1913, of which the purpose was evidently to calm the sentiments of the United States. In a speech to Congress, December 2, 1913, he enlarged on the duties of his country as the champion of constitutional government. The essential statements in the two utterances are as follows :

"We are the friends of constitutional government in America ; we are more than its friends, we are its champions; because in no other way can our neighbors, to whom we would wish in every way to make proof of our friendship, work out their own development in peace and liberty."

"You hear of 'concessions' to foreign capitalists in Latin-America. You do not hear of concessions to foreign capitalists in the United States. They are not granted concessions. They are invited to make investments. The work is ours, though they are welcome to invest in it. . . . States that are obliged, because their territory does not

Subordination through Concessions. lie within the main field of modern enterprise and action, to 
grant concessions are in this condition, that foreign interests are apt to dominate their domestic affairs. . . . What these States are going to seek, therefore, is an emancipation from the subordination, which has been inevitable, to foreign enterprise. . . . The dignity, the courage, the self-possession, the self-respect of the Latin-American States, their achievements in the face of all

Inequitable

Debt Conditions. of loans than any other peoples in the world. Interest has been exacted of them that was not exacted of anybody else, because the risk was said to be greater, and then securities were taken that destroyed the risks. ... I I rejoice in nothing so much as the prospect that they will now be emancipated from these conditions, and we ought to be the first to take part in assisting in that emancipation.... In the future they will draw closer and closer to us, because of circumstances of which I wish to speak with moderation and, I hope, without indiscretion. ...

"The United States will never again seek one additional foot of territory by conquest. She will devote herself to showing that

No more

Conquest by the United States. she knows how to make honorable and fruitful use of the territory she has, and she must regard it as one of the duties of friendship to see that from no quarter are material interests made superior to human liberty and national opportunity. . . . It is the relationship of a family of mankind devoted to the development of true constitutional liberty. ... .

"America is a name which sounds in the ears of men everywhere as a synonym of individual opportunity because a synonym of individual liberty. . . .

"In emphasizing the points which must unite us in sympathy and in spiritual interest with the Latin-American peoples we are only

Spirit of the United States. emphasizing the points of our own life, and we should prove ourselves untrue to our own traditions if we proved ourselves untrue friends to them."

Some light is thrown upon the view of the Administration by a public statement made by Page, American Ambassador to England, in 1914, in an address the spirit of which must have been approved by the authorities in Washington.

"I sometimes read that the United States is entering upon a policy to discourage foreign investments there. That is untrue. ... There is a policy forming in the minds of our Government and our people, which is not new, that would discourage such 
investments or concessions as would carry with them the control of the Government of any of those States, and only such. . . . You may be assured that it is none of the business of the United States to put any let or hindrance upon any legitimate investments of yours anywhere in the world, and they most heartily welcome your

No Interference with Foreign Investments. investments in any part of the Americas, 'provided only you do not make them so that you may possibly take the country with them.

" The Monroe Doctrine meant this, when it was first formulated : that the United States would object to any European governments taking more land in the New World. In those days the only way that a foreign Government could gain land was literally to go and take it. Now we have more refined methods of exploitation, and there are

No Annexations for European Interests. other ways to take it. That is the only protest that the United States has ever whispered.

"You will, I am sure, understand why the United States prefers that no land in the New World should be acquired in these new, subtle ways."

\section{THE WRITTEN AND THE UNWRITTEN AMERICAN DOCTRINE}

Throughout the volume, up to this point, the attempt has been made to show how the various utterances which might be considered to commit the Government have fitted in with the conditions from decade to decade. The Monroe Doctrine is not an utterance, nor a series of utterances, but a frame of mind, the nature of which is from time to time described in the generalizations of those who are in a position to know the facts and also to gauge the temper of their country. A comparison of the more or less detailed statements made by Monroe, Adams, Polk, Cass, Buchanan, Seward, Fish, Evarts, Blaine, Olney, Cleveland, Roosevelt, and Root shows clearly that not one but many doctrines have been stated. With all the efforts of doctrine makers to refer for authority back to "Chapter I; Attitude of James Monroe," the number of doctrines since 1849 is about the same as the number of Secretaries of State.

An obvious reason for this variety is that the rapid changes of circumstances have made it impossible for any President or Secretary of State to begin where his predecessor left off. The elements of the American problem are so many that no mind can grasp them all, and no one can invent a formula that will cover them all. It would be highly agreeable to believe that 
the United States has for nearly a hundred years followed a simple and persistent plan which was perfectly understood by other nations and was therefore a fair warning to them of what the United States would do under given circumstances. The simplest form of the doctrine is Root's nervous phrase, "That the safety of the United States demands that American territory shall remain American," but even that reduced form does not answer the question whether annexations by the United States are within the American Doctrine, against the American Doctrine, or outside the American Doctrine. So far as his phrase goes, Root might agree with Douglas in "Manifest Destiny."

The essential difficulty with the American Doctrine is that the United States has for nine decades been trying to lay down general rules for the conduct of European powers and other American powers in the Western hemisphere, so far as that conduct may be unwelcome or hurtful to the United States. Yet no written doctrine or doctrines can teach us all we wish to know about the actual needs and conditions of America. The scribes have been too many, and they have used too many kinds of handwriting. The American Doctrine is not a paper statement of what the United States thinks to be, but a summary of what the United States and other nations have actually done.

The remainder of this volume will be devoted to the attempts by publicists, by other American pens, and by foreign writers, as well as by the United States, to frame a set of principles which will cover particular difficulties. Some of these suggestions or policies might be called Anti-Monroe Doctrines. In each group. of instances the position of the United States must be described: for no form of the Monroe Doctrine has ever been put forth as an abstract principle. Every statement and counter statement has been made to defend some immediate interests. The seriousness of the whole situation is that it is one of conflicting national aspirations. How can any one of the parties concerned find a formula which will satisfy all the other parties? 


\section{PART IV \\ PRESENT-DAY DOCTRINES}

\section{Chapter XV \\ THE LATIN-AMERICAN DOCTRINE}

THE MONROE DOCTRINE ONE-SIDED

That the people of Latin America are entitled to any share either in shaping or in applying the Monroe Doctrine which has been so often brought to their notice, is comparatively a recent idea. They were expected to welcome the original announcement of 1823 with joy. They were duly pleased, and in the Panama Congress of 1826 intended to talk things over with the United States, so as to re-state the Doctrine in a practical form which all the world would recognize as the joint view of America.

The Panama Congress, like every Pan-American meeting since that time, discussed matters which it could not settle, passed resolutions which it could not carry out, and drew up treaties which it could not put in force. People of the Spanish strain deceive themselves as to the effect of strong words and a well-drawn document. Instead of their sitting in council with representatives of the United States, important decisions have been made for them against their will. Buenos Ayres was snubbed about the Falkland Islands in 1831. The destinies of Cuba from first to last were settled with little attention to the wishes of the Cubans. The present relation of that Republic to the United States is not what its people would adopt if they had a chance to express their minds by a popular vote.

The Canal policy had to be discussed with the Isthmus states, and is about the only question on which there has been mutual study; the State Department has often proposed that 
the other side grant concessions; and one power has even drawn up two pacts with regard to the Canal and asked the United States to adopt them. This is Colombia, whose treaty of 1846 was the free offering of that country, grudgingly accepted by President Polk. The Hay-Herran Canal Treaty of 1902 was also drawn by the government of Colombia, but their own people refused to ratify it. The pleas of Latin-American states for support against pressing foreign demands have not always met a ready response. Seward's action toward Mexico during our Civil War was years behind what the Mexican popular government expected. The Central American states have been little consulted about their future. Venezuela found in the United States a champion against England in 1895, but only a limited support in 1902.

Hence the strong belief among Latin-Americans that the Monroe Doctrine was never made for their benefit, and has never been appealed to by the United States except for her own purposes. In the Pan-American Congresses, the representatives of the United States have always been ready to talk; but only two or three of the dozens of measures proposed by those meetings have been adopted by the United States government. A unilateral doctrine has never been to the mind of Latin America.

\section{RIGHT OF LATIN-AMERICANS TO THINK}

Nevertheless, the United States has not intended to ignore her neighbors' right of international discussion, a right which is so valued in our own affairs. We admit it in an irritating way, because as a nation we think our neighbors to the south are political children who have about the same rights that minors have in the ordinary community. They are to be protected from harm, kept out of mischief, given playthings to occupy them, and promised their own way when they are old enough to be called political men. To a complaint that wings its way northward, a ready answer is that the decisions "down there" are made by military despots; that there is no evidence that they consult their own people or are guided by public sentiment.

From one side, the North Americans have for a century claimed a peculiar interest in their southern friends, because they are republics; on the other side, the United States makes little effort to deal with the populations of Latin-American 
countries, and usually recognizes the head of the state, however crooked or bloody the road by which he reached that place. A curious phenomenon in American diplomacy is that representatives of the great Republic who go into Latin-American republics, often come back home full of admiration for the dictator and his chiefs, with whom they have been on cordial terms. Diaz reigned by the usual arts of despotism: by silencing, banishing, occasionally shooting those who tried to work up a party against him; but minister after minister to the United States assured us that Diaz was a great ruler, of just the kind that was needed in every other Latin-American State.

There is, however, a public opinion in Latin America, which is capable of passing upon the foreign policy of their rulers and the friendly or unfriendly attitude of the United States. Every despot must have about him some honest and public-spirited men, as administrators, foreign ministers, and writers on public law, to carry on his administration and to screen him from the criticism that he is a despot. Latin America has also developed a class of publicists. The symmetry of Spanish law - which at bottom is Roman law - seems to train men to think accurately and to form brilliant generalizations on complex problems. It is not an accident that Calvo, a Brazilian, was till his death in 1906 a master in international law. Washington has received in late years a score of highly-educated, well-trained, hard-thinking representatives from Latin-American states. About five hundred young men from those countries are carrying on studies in the United States, in law, government, language, science, and engineering. They expect to be the leaders of the next generation. The universal testimony of visitors to Mexico and to Central and South America is that there is in every country a class of well-trained, high-minded, and able men, who have a right to think about the American Doctrine and speak and write about it, even if they could not read their title clear to complete free speech on home affairs.

\section{PHYSICAL POWER OF LATIN AMERICA}

If large numbers both of communities or people give nations a right to act on world questions, Latin America has a just claim to take part in framing general international principles which are to regulate their concerns. In North and South 
America exist eighteen republics in which Spanish is the official language ; one, Haiti, in which French is used ; and one, Brazil, in which Portuguese is the usual tongue. As for population, these twenty states count 75 millions against 100 millions for the United States in America, and 10 millions for all the British possessions, both Canada and the islands. The distribution of these numbers is shown in the following table, the various countries being arranged in the order of their total population.

1. United States (Continent, Porto Rico, and Canal Zone)

2. Brazil

4. British Possessions (Canada, Newfoundland, $\dot{W}$ est Indies, Guiana, Honduras, Falkland Islands)

5. Argentine

6. Colombia

7. Peru

8. Chile

9. Venezuela

10. Cuba

11. Bolivia

12. El Salvador

13. Uruguay

14. Haiti

15. Paraguay

16. Santo Domingo

17. Nicaragua

18. Honduras

19. Guatemala

20. French Possessions

21. Ecuador

22. Costa Rica

24. Putch Possessions (West Indies and Guiana)

Population

25. Danish Possessions (West Indies) Total

$100,000,000$

$24,000,000$

$15,000,000$

$10,000,000$

$7,500,000$

$5,300,000$

$4,600,000$

$3,500,000$

$2,500,000$

$2,400,000$

$1,800,000$

$1,200,000$

$1,250,000$

960,000

850,000

680,000

600,000

570,000

560,000

450,000

400,000

400,000

360,000

100,000

30,000

$\overline{185,050,000}$

This showing is not so favorable for the influence of the LatinAmericans, as the numbers suggest; for they are sub-divided into many lands and nobody has ever succeeded in bringing all of those lands under one system, or into alliance for one object. Furthermore, the best friends and strongest admirers of the Latin-Americans would admit that the average intelligence and capacity of the whole population is decidedly below that of the United States or Canada.

Latin America is like Europe in the great variety of size and power of the political units within the same continent. Nine so-called nations have a population of less than a million each, 
and nine more are under ten million each. Such units do not much impress the world. How much attention will be paid to the public opinion and ambitions of Santo Domingo and Ecuador and Costa Rica? It seems impossible that any such countries can ever become a real international force.

Some of these countries, especially Brazil and the Argentine, are growing. Others, like Mexico, are just now about at a standstill. It is likely that both the American and British communities in North America will keep on growing rapidly and there seems no prospect of the Latin-Americans catching up.

\section{RACE AND SOCIAL CONDITIONS}

The United States has been going ahead in strength, influence, and wealth, ever since Monroe issued his Declaration in 1823. What are the conditions of Latin America? In some countries the race conditions have changed very little during a century. In Mexico, for instance, the proportions of the Spanish race, mixed race, and the Indian race, are probably about what they were then. American or English immigration has not affected the population of a single Latin-American state. Direct Spanish immigration appears to have been very small till recently. At present there is a steady immigration into the Argentine, which in 1912 received about 300,000 immigrants of whom 160,000 were Italians and 80,000 were Spaniards, and there are supposed to be over 1,000,000 Italians in the country now. To Brazil came in the same year about 180,000 , of whom 75,000 were Portuguese, and 35,000 Spaniards. The German immigrants to Brazil were only 6,000 , but for many years they have been coming steadily, and it is supposed there are 300,000 or more in the southern provinces of Brazil. In Mexico and some other countries there is a class of Spanish business men who take advantage of their knowledge of the language and the habits of the people to set up their establishments in the Western World.

Nowhere are the foreign elements large enough to give them control of the governments or to disturb the rule of the descendants of the Portuguese and Spanish colonists, fortified by the immigration that is now going on from Spain and Portugal. The Spanish countries all remain Spanish in language, law, education, and religion. The Church in several countries, es- 
pecially in Mexico, has been drawn into the intensest politics; and in Peru up to 1914 it was still law that the practice of no religion except that of the Catholic Church shall be allowed in the Republic. Those who visit Latin America admire the courteous manners of the people and make warm friends. Chosen youth go to Europe or to the United States for an education, especially in scientific or technical lines. Most of the countries possess universities of the grave and carefully regulated type.

Nearly every Latin-American country, excepting Cuba and the two republics of the island of Haiti, contains an Indian and mixed population ranging from a small fraction to three-fourths of the whole. In Brazil, Cuba, Haiti and Santo Domingo, the mixture is with the negro descendants of former slaves. Notwithstanding the splendor of some of their cities and the wealth of great landowners, Latin America is poor. The whole western range of country from Mexico to Chile is plagued with mountains and deserts, and in the richest and most fruitful regions the laborers are poor and live poorly.

Hence, notwithstanding seventy-five millions of people, the per capita Latin-American trade is far below that of Europe or the self-governing English colonies of Canada, Australia, and South Africa. Brazil and the Argentine are magnificent countries with great advantages for growth and wealth. Large parts of them lie in the temperate zone and they seem destined to become the seat of mighty peoples. The valley of the Amazon farther north in the tropics is scarcely opened and may become another Ganges in the world's history. Mineral wealth abounds in many parts of Latin America, coal in Brazil, precious metals all the way up and down the Andes and the Cordilleras, and nitrates on the west coast of South America. In timber, fruit, rubber, coffee, and sugar there is an opportunity for a great world trade.

\section{LATIN-AMERICAN GOVERNMENT}

Every Latin-American country is now in form a republic, yet no government really proceeds from the people. The Spanish tradition is of an upper class, out of which governors and judges and magistrates are taken. Alongside this practically hereditary element is a group of prosperous business men, 
planters, merchants, and capitalists, who expect to share some of the good things of government. Then there is a class of political soldiers; such men as Villa of Mexico, who have come out of the depths and never get far away from their origin. Whenever they break into the sacred circle, government is turned into a squabble for the control of the treasury.

A country like the United States, in which three Presidents have been assassinated in thirty-five years, has hardly a right to say that there can be no popular government where murder is a part of the governmental machinery; still whenever a military officer of no special note kills his President, in order to make himself President, the result is swift military despotism. The A B C powers for the last twenty years have kept up peaceful changes of the heads of the government; but there was a revolution of the navy in Brazil in 1893; a revolution by Congress against a president in Chile in 1891; and a revolution in the Argentine in 1890, and a revolt in 1893 . Mexico has ever since 1911 been going through one contortion of war and destruction after another.

Whatever the cause, the fact remains that no Latin-American country is free from the danger of revolution at any time; and that most of them are unable to set up any kind of government of their own which will last more than a year or two. The disturbances of internal government react on all the relations of Latin-American States with each other and with the outside world. Except for the A B C powers, there is no group of friendly neighboring states.

Latin America is not the only part of the world in which there are weak and quarrelsome governments: but, outside of the A B C powers there has been little gain from the experience of a century. These various lands have increased in population and in property, but not in the good order and protection to the individual which is the necessity for business at home and for foreign trade, as well as for the social development of the nation. Mexico has never had a worse four years of revolution than from 1911 to 1915. Guzman Blanco and Castro, recent dictators in Venezuela, were as pompous as Bolivar and as tyrannical as Santa Anna. After a century of effort and suffering, most of Latin America is in the same condition of political childhood as when it came out from under the Spanish Empire. In the less developed countries the executive changes 
often and it is difficult to carry out treaties; above all, the troubles within extend to resident foreigners and their appeals bring their home governments into the disturbance.

\section{LATIN-AMERICAN UNIONS}

Considering the unity of language, law, traditions, race, religion, and intellectual training, we naturally expect a Latin political union. A United States of Latin America with seventyfive million people would be one of the world's great powers; could remove most of the difficulties and friction which have led to interventions; and could protect all its territories against colonizing schemes of other powers. It might even make head against the United States and insist upon an understanding which would shut out the great northern republic from laying down anybody's Doctrine as a rule which her neighbors must observe. Ever since Bolivar, some Latin-American leaders have glowingly set forth the advantages, the uplifting power, and the absolute necessity of Latin-American union. Yet the recent Pan-American Congresses have not led in that direction.

Such a union was impossible from the start. To say nothing of the difference of feeling between the Portuguese and the Spanish elements in the New World, there never was any unity among. the Spanish colonies. They were separated by immense distances, and trade between them was for several centuries frowned upon by Spain. When they became independent their forms of government did not fit in with international unions. At the present moment, there are four nominal federal governments in Latin America: Mexico, Venezuela, the Argentine, and Brazil. In not a single one have the internal States ever been allowed to look after themselves as do the States in the successful American union. Local self-government cannot exist in the midst of civil wars and despotisms. Every one of the twenty Latin-American republics has a so-called Congress: in how many is there real legislative power of their own? Such communities could not possibly be expected to obey the edicts of a general Congress in which their own deputies may be out-voted.

Thoughtful Latin-Americans have striven to bring about closer approach by associating neighboring powers. From time 
to time alliances have been formed by groups of neighbors. None of these alliances have stood the test of time, except that which is described in the next section.

\section{THE A B C COMBINATION}

How does it come about that the United States with her thirty races contains only one people, while Spanish America, with nearly uniform race conditions, shows such objection to real union? We may leave out of account Cuba and Panama, which are satellites of the United States, and the West Indian colonies of England, Holland, France, and Denmark, which are subject to European control. The remaining units out of the former Spanish and Portuguese colonial empires in America have sorted themselves out into three groups:

(1) The first is the small, weak states of Central America, the island of Haiti and the mountain country of Western South America, with a few others, such as Paraguay. None of these have the population or the character to grow into vigorous countries which might fairly claim to be members of the family of nations.

(2) Another group of states, Colombia, Peru, Venezuela, Bolivia, and Uruguay, contain a larger population but are at present notoriously unstable and unable to keep peace within their own borders, or to avoid difficulties with their neighbors.

(3) The next important group is made up of the Argentine, Brazil, and Chile, with a combined population of $35,000,000$. They are the richest, most prosperous, and most orderly of all the Latin-American governments; and of late years they have several times acted together as a group and almost as an alliance. They occupy a broad band of contiguous territory which stretches from the southern boundary of the Guianas, and all the way around the coast of South America, including the magnificent rivers of the La Plata and the Amazon, as far as the Straits of Magellan. Chile is well to do, partly because of the nitrate beds taken from Peru in 1881. Brazil has a tight hold on the coffee supply of the western world. The Argentine has almost taken the place of the prairies of the United States as an exporter of grain and animal products.

The A B C countries are perfectly aware of their place in the good society of nations, and in 1914 and again in 1915 they 
acted together in trying to bring the Mexican people to their senses. Each of them is able to call upon a public opinion, which exists outside of the orders of the government, and must be taken into account on such questions as the American Doctrine. Not one of the A B C States is likely to be attacked by a foreign power on any grounds; none of them fears the United States. They are all trying to build up a capable army and a navy which, however small, shall include powerful modern ships. They are the leaders in the Pan-American movement; hence the three capitals of Buenos Ayres, Rio, and Santiago have since 1900 entertained two Pan-American Congresses and one Scientific Congress.

Mexico would naturally have been a part of this combination but for the breakdown of the Diaz régime in 1911. Its great stores of minerals, and oil, its cotton fields and fruit farms, made it one of the most prosperous of all the Latin-American states. It was considered the standing proof that LatinAmericans could be trusted to form an enduring state. The only explanation of Mexico's woe is that even benevolent despotisms wear out at last; and the question arises whether the A B C powers have any insurance against a like fate overtaking them. At present they seem stable. None of them is controlled by a single despot; the real force in their government appears to be a wealthy class of planters and land-owners and miners, with a nominal popular government behind them.

\section{LATIN-AMERICAN LIKING FOR THE MONROE DOCTRINE}

Everywhere in Central and South America people who know anything about the rest of the world are aware that there is a mysterious something called the Monroe Doctrine, which purports to have come into being for their benefit. They also understand that President Monroe was only the conduit through which this life-giving spring first reached the world. They know that the Monroe Doctrine is not a document or a policy but a national frame of mind. It is not even a clear and welldefined frame of mind, but works by fits and starts. When Venezuela in 1895 appealed to that Doctrine, the United States arose in majesty and defended her neighbor. When the Venezuelans in 1902 again appealed to the United States, they were indeed protected from invasion, but not from such disagreeable 
consequences as blockades, bombardments, and the capture of vessels. To the Latin-Americans, therefore, the Monroe Doctrine is something like the knob of a bell-pull, which you ring when there is a fire; you hope the fire engine may come; and you hope it may not run over you; but you are not sure in either desire.

\section{Dr. Drago has said of it:}

"The Monroe Doctrine is in fact a formula of independence. It imposes no dominion and no superiority. Much less does it establish protectorates or relation of superior to inferior. It creates no obligations and no responsibilities between the nations of America, but simply calls upon all of them with their own means and without aid, to exclude from within their respective frontiers the jurisdiction of European Powers. Proclaimed by the United States in the interest of their own peace and security, the other republics of the continent have in their turn proceeded to adopt it with an eye alone to their own individual welfare and tranquility.... Thus understood, the Monroe Doctrine, which in the end is nothing more than the expression of the will of the people to maintain their liberty, assures the independence of the states of that continent in respect to one another as well as in relation to the Powers of Europe."

The representative of Brazil at the Pan-American Conference at Buenos Ayres even proposed a resolution to the effect that -

"Latin-America sends to her great sister nation of the north an expression of her thanks for that noble and unselfish action which has been of such great benefit to the entire New World."

Senator Calderon of Peru extended his admiration in the suggestive remark:

"The Monroe Doctrine, which liberated Latin-America from the tutelage of the Holy Alliance, is perhaps destined to protect it also against the Orient."

The Latin-American states have always been willing that somebody else should protect them from European aggression, as was shown, in 1896, by President Diaz of Mexico, who said :

"Each one of these republics ought by means of a declaration like that of President Monroe, to proclaim that every attack on the part of a foreign power, with the view of curtailing the territory 
or independence of, or of altering the institutions of any one of the republics of America, would be considered by the nation making the declaration, as an attack on itself."

\section{LATIN-AMERICAN DISLIKE OF THE MONROE DOCTRINE}

If the Monroe Doctrine justified the support of the Republic of Panama by the United States, every power in that part of the world was certain to oppose the Doctrine. It is common sense for the Latin-Americans to be willing to accept the powerful protection of the United States against European powers; and equally common sense to oppose anything that looks like a leadership over them. An American writer on Colombia has recently said that -

"Even in this enlightened age every nation seems to have a bugaboo of an impending foreign enemy - England, Germany; the United States, Japan, and so forth. So Colombians dread a Yankee attempt, sooner or later, to overpower South America and believe their land to be the outpost which will be first attacked. They have already felt the talon of the Eagle."

Evidence that the Monroe Doctrine is usually looked upon with suspicion is too strong to be denied. Recent travellers and visitors find an atmosphere of distrust. Professor Hiram Bingham, who knows the language, has explored the interior, and is not looking for trouble, quotes diplomats, business men, and literary men to that effect, including James Bryce. One Chilean sums up his opinion in the phrase:

"We don't want any Papa."

An editor says :

"The Monroe Doctrine implies a moral subordination to the United States which is repulsive to the national feelings of the young republics."

Perez Triana, formerly President of Colombia, sharply criticizes the United States as follows:

"The American Continent, with the exception of the colonies belonging to the belligerent nations, is outside the political radius of the reign of barbarism under which any colonies which Europe might acquire in America would come. . . . 
"The principle laid down by the United States is by no means based on disinterested, altruistic, or humanitarian motives, but solely on the advantage of that nation, on a desire for isolation from the powers of the western hemisphere and their troubles. . . .

"The United States, while preventing the conquest of American territory by European nations, has not been logical nor honest ; it has not respected the essential equity of the principle, for it has conquered territory by violating the sovereignty of other American nations."

The dislike of the Monroe Doctrine in many cases goes over to those who apply the Monroe Doctrine. The general testimony of those who have recently been in Latin America is that the Yankee is unpopular. He looks down upon the Latin people whom he visits, rarely learns their language, and has a low opinion of their abilities. A great part of the trade is in the hands of English, German, and other banks and importers from Europe. The United States has not a large commerce, and the Latin-Americans complain bitterly that American merchants will not adapt themselves to the trade conditions of the country. The Americans retort that the business conditions of Latin America are a hollow shell and that the people who have been doing the business must shoulder the losses. It is hard for the two races and the two political systems to understand each other or to work together.

\section{THE LATIN-AMERICAN REMEDY}

In the long run neither the Monroe Doctrine nor any other great line of international action will ever be supported by the Latin-Americans unless they can have a hand in framing it. In the present conditions of the world, invasions of Latin America seem more probable than for many years past; and there is a great need of bringing the American powers together beforehand. That is what the Latin-Americans want, but what the United States does not want. In a congress of sovereign powers, each equally independent, every one claims to vote as a unit on general questions; but the United States will never consent to be outvoted even by a majority of twenty republics to one, on any question of defense and assurance of her future in the world. So far, even the A B C have not been admitted into the confidence of the United States, beyond giving 
advice. For the United States is no readier to yield to a vote of three to one than twenty to one. Hence the two forces of Pan-Latinism and Pan-Americanism work against each other.

Some little effort has been made to form a sentiment in favor of Pan-Iberianism, that is of a union of friendship, commerce, and perhaps some kind of government in which Spain, Portugal, and all the Spanish and Portuguese-speaking peoples shall take part. The taking over of the Philippines, Cuba, Porto Rico, and Panama by the United States subtracts four areas from this project; and the renewal of special relations with Spain would be an alliance with a weak and distant power, against a strong nation which is at the gates of Latin America.

To satisfy the A B C powers does not mean to satisfy Latin America. It leaves the world face to face with a group of small, undisciplined, and changeful countries, which will certainly do what they think best for their own destinies, unless restrained by the force of their neighbors. Any partnership or union or arrangement that can be thought of, still leaves in existence a group of dissatisfied and tough little countries which will not accept anybody's fiat. Some kind of Doctrine may be worked out which contents both the United States and the A B C powers; but a doctrine which does not also please the small States is only the old Monroe Doctrine over again. It is a rule of action laid down upon them by outsiders, for the advantage of those outsiders.

Manifestly there can be no American combination or alliance in which the United States will not be the most powerful factor. The A B C powers would be quite satisfied with an arrangement which recognized them as selected partners with the United States; and under any stress of danger they would admit the superior power and therefore the superior judgment of the United States. Still, the conditions would be much like those of the New England Confederation of 1643, in which Massachusetts had more population than the other three constituent States put together; and Massachusetts once flatly refused to accept a vote of the other three as binding on her. It is impossible to get rid of that fateful arithmetic. Either the greater must yield to the less, or the union dissolves. 


\section{Chapter XVI}

\section{DRAGO DOCTRINE AND CALVO DOCTRINE}

\section{2-1915}

\section{THE INDIVIDUAL IN AMERICAN AFFAIRS}

WE think of the American Doctrine as something which affects only nations: we conceive that the United States stands as a defender between Mexico and Germany, or England and Santo Domingo. In actual operation the American Doctrine has of late years usually been set in motion by the troubles of individuals. A Pennsylvanian goes down to Guatemala to raise bananas, and straightway becomes a storm center in international relations. His right to buy land, to carry on business, to be protected from brigands and rapacious officials, at once affects the relations of the government of the United States with the government of Guatemala. So when Castro, exPresident of Venezuela or Huerta, ex-President of Mexico, comes to the "States," he finds that he is not a simple visitor; he disturbs the friendly relations between his former country and the United States.

The same thing may happen in the case of citizens of the United States who visit European countries; but almost anywhere in Latin America the foreigner finds two special difficulties : revolutions and weak governments. Revolutions mean disorder, pillage, violence, and often murder both of natives and of resident foreigners. Weak governments take as much as they can of the foreigner's property and often refuse to stand by the concessions and privileges granted by a previous ruler or government. In addition, the weak government borrows money abroad and then neglects to pay the interest. That makes the foreign investor or stockholder in a company carrying on business in a Latin-American State a party to the ravages and the injustices of both revolutionary and recognized governments. 
This capacity of the alien to make trouble between his original country and his country of residence extends farther. The American railroad builder whose contract is broken appeals to his government to put a pressure upon the government which has ill used him, and files a claim for damages which may be twenty-five years in dispute. The German bondholder asks his government to back up the demand for interest and unpaid principal by a show of force.

Such demands, starting with individual rights and the failure of weak governments to protect the alien, have frequently led to threats of intervention which have called up the question whether the American Doctrine stands in the way of enforcing such claims. To meet this point several ingenious statements of policy have been evolved of which the most striking are the so-called Calvo Doctrine, against any intervention; and the so-called Drago Doctrine, against intervention for the collection of debts. The purpose of both these doctrines is the same as that of the American Doctrine - to prevent wars and territorial seizures which would change the conditions of America and bring Europe into closer contact with American affairs.

\section{RIGHTS OF ALIENS IN LATIN AMERICA}

Little trouble arises in Latin America from the ordinary tourist, travelling business man, or scientific explorer. They come and go easily, often steering a safe course between revolutions. It is different with those citizens of the United States and European powers who settle down to make their homes in Latin America : for few of them accept naturalization in those countries; instead, they remain citizens of a home country which has some power to protect them. The archives of the consulates and the legations are full of demands for such protection, and the belief that these demands will be listened to, is a daily restraint on the Latin governments. The result is that the foreigner is far less likely to be overtaxed, or plundered, or to see his property destroyed by revolutionaries. The foreigner expects to keep his property and to save his life in times of disturbance, and if he is ill treated, counts up his injuries and makes out a bill which he expects his own government to press.

To meet this difficulty many of the Latin-American states 
have made constitutions or passed laws which are intended to take away this favored status. They argue that no foreigner is obliged to come to a Latin-American country; and if he comes he must accept the laws as he finds them. For instance, a Venezuelan statute of 1903 contains the following provisions :

"Foreigners shall enjoy the same civil rights that the constitution of the Republic gives to Venezuelans. . . .

"Domiciled foreigners who violate any of the provisions enumerated in article 6 lose their status as foreigners and ipso-facto become bound by the same responsibilities and obligations as natives in all political contingencies. . . .

"Neither domiciled nor transient foreigners have the right of recourse to the diplomatic channel except when, after having exhausted all legal methods before the competent tribunals, it shall clearly appear that there has been a denial of justice, notorious injustice, or an evident violation of the principles of international law. . . .

"Neither foreigners nor Venezuelans can claim from the Government of Venezuela compensation for losses or damages occasioned them by armed agents or bodies in the service of any revolution, but they can bring a personal action against the authors of the losses or damages."

No act of a Venezuelan Congress can take away the foreign citizenship or the rights of an alien; but it can make it more difficult for him to get justice by ordinary methods. The alien creditor who lives in Europe or the United States is treated often with much the same off-hand denial of his rights : for instance, the government of Ecuador has positively guaranteed with its entire custom house receipts the payment of the interest and principal on certain railway bonds. The bonds are now three years in default, the price has run down from 94 to 35 , and the bondholders are whistling for their money. So far as revolutions are concerned, the United States government during our Civil War always insisted that it was not liable for property destroyed by the Confederates, and we are obliged to recognize the same principle with regard to the Latin-American revolutions. What is to be done when a regular, recognized government seizes property or annuls contracts or neglects to pay interest on bonds belonging to the citizens of other countries? 


\section{COLLECTION OF PUBLIC DEBTS}

The Administration in Washington became at last sensitive on the general irresponsibility of the smaller Latin-American powers and especially their indifference to their debts. This whole subject of the public debts of bankrupt nations is mysterious. Every despot tries to create a foreign loan, which becomes a perpetual burden on his country. Bankers, European and American, can be found, who will advance moderate sums on the pledge of revenues. The transaction is frequently greased by valuable concessions of land and privileges. Sometimes the nominal head of the state accepts a fraction of the face of the bonds and makes his country responsible for the full face. Nobody in his senses would take a loan from such a state on fair and open terms, expecting regular interest and eventual repayment of the principal.

Debt troubles of this artificial kind have especially disturbed the Central American states, to which people's minds turned after the acquiring of the control of the Isthmian canal. The "coast line of the United States" idea of President Hayes came as a suggestion for special attention. The three succeeding administrations of Roosevelt, Taft, and Wilson felt a special sense of responsibility for improving the poor governments in that neighborhood, and straightening out their debts. Central America was a nest of rival and revolutionary states. The natural solution was to repeat the methods used on Santo Domingo, which seemed to please everybody concerned. The Dominican bondholders were practically secured to the amount of $\$ 15,000,000$, which was more than they could have extracted in fifty years from the negro republic. The Dominican authorities appear to have realized more net cash than when they nominally received the whole sum. The State Department was doing a good work, and at the same time keeping the European Political System at bay. The whole thing was too successful. The theory seemed to be that if it went well with one delinquent republic, it ought to go ten times better with ten delinquent republics. Elsewhere on the map could be found the same combination of European creditors, empty treasuries, and the possibility of foreign powers taking possession of an American state as a pledge for its debts. 


\section{CLAIMS AND ARBITRATION METHODS}

In the course of years a kind of system has been worked out for dealing with interferences, or alleged interferences, with citizens of the United States. (1) The claimant is expected first of all to remonstrate to the government of the country in which he claims to be injured. (2) If it is a question of property, he is expected to bring suits in the courts of that country and our State Department will usually do nothing for one of our citizens until he can make out a case of "denial of justice." (3) Then the attention of the delinquent government is officially called to the case; Washington keeps calling it. (4) Bye and bye, - it may be some years later - the demand is made that this and like cases be included in a treaty which will provide some method of finding out whether the claims are valid. (5) This pressure usually results in course of time in an arbitration or a commission to examine and report on the claims, or to make awards. (6) The damages found by such a commission then have to be provided for by a money payment. (7) There's the rub, for by this time the head of the state may be the bitterest personal enemy of the former dictator who caused the trouble. It is like pulling teeth to get money from a government, no member of which had a hand in the original injury. The United States went to war with Mexico in 1846, partly because claims had been accumulating for about forty years and the money was not forthcoming. What shall foreign governments do to avoid the same tedious process?

The question is complicated by the fact that many of these claims are false at every stage from start to finish. The final awards by a commission are often from one fourth to one tenth of the amounts claimed. The United States has twice used its diplomatic machinery to force a settlement of claims which it afterwards discovered to be fraudulent. In one of these; the La Abra case (1875) the arbitrators made an award of about $\$ 683,000$. The Mexican government at once began to fight it and after years of effort, our Congress passed an act' re-opening the case. After about twenty years of fierce discussion, the Supreme Court of the United States held that the award had been obtained through fraud and Congress returned to Mexico $\$ 400,000$, the remainder having early been paid over to the fraudulent claimants. A similar award made 
in 1885 in the Pelletier case against the Republic of Haiti was thrown out by the State Department on the ground that it was unjust. There have been some similar cases in which arbitrations between European powers and Latin-American powers have been disputed. One such difficulty led in 1898 to a naval demonstration against Colombia by the Italian government.

Notwithstanding the honorable willingness of the United States to reconsider awards in a few bad cases, there is a widespread feeling in nearly every Latin-American state that all the big and powerful nations support their citizens in excessive claims. On the other hand, of course, there are many undoubted cases of scandalous seizures of property and injuries to persons, such as would cause war if they were practised by one European government upon another. The obvious way of dealing with weak governments under such circumstances is to send a naval expedition, which lands a small force and announces that it will stay until the grievances are redressed.

\section{THE CALVO DOCTRINE (1867-1915)}

Latin America is especially subject to such troubles because it is a debtor region. The governments habitually borrow up to the limit of their credit. The railroads are built mostly by foreign capital and very heavy investments are made by foreigners in mines and other enterprises. Weak governments which are always in debt furnish the best possible field for interventions. Calvo, the Brazilian, a world authority on public law, in his great work on International Law, first published in 1867, laid down the following principle:

"Aside from political motives these interventions have nearly always had as apparent pretexts, injuries to private interests, No Interventions for Debts and Claims. claims and demands for pecuniary indemnities in behalf of subjects or even foreigners, the protection of whom was for the most part in no wise justified in strict law. ... According to strict international right, the recovery of debts and the pursuit of private claims does not justify de plano the armed intervention of governments, and, since European states invariably follow this rule in their reciprocal relations, there is no reason why they should not also impose it upon themselves in their relations with nations in the new. world." 
In the reference to "interventions" in this passage, Calvo meant to deny to foreign governments the right to insist on the collection of debts due to their subjects, whether they were due from a Latin-American government or Latin-American citizens. Elsewhere in his work and in later editions, Calvo made his doctrine more explicit.

"It'is certain that foreigners who establish themselves in a country have the same protection as nationals, but they can not lay claim to a protection more extended. If they suffer any wrong they ought to expect the government of the country to pursue the delinquents, but they should

Foreigners not Privileged. not claim from the state to which the authors of the violence belong any indemnity whatever.

" 1 . The principle of indemnity and diplomatic intervention in behalf of foreigners for injuries suffered in cases of civil war has not been admitted by any nation of Europe and America.

" 2 . The governments of powerful nations which exercise or impose this pretended right against states,

Diplomatic

Interven-

tion for

Injuries. relatively weak, commit an abuse of power and force which nothing can justify and which is as contrary to their own legislation as to international practice and political expediency."

Calvo's Doctrine clearly pronounces against any foreign government taking the responsibility of even urging the claims of its citizens. He clearly denies the right of a government to remonstrate or to try to get a settlement of any claims. Though Calvo's Doctrine is put in general terms it has been applied by the author and by others as especially suitable for the protection of Latin-American powers. Calvo's purpose in arguing and elaborating his doctrine was to put a stop, first to armed interventions, and second to diplomatic protests, for "the recovery of debts and the pursuit of private claims." He does not deny that armed intervention or diplomatic protest may be used in cases of the ill treatment of persons, whether officials of foreign governments, travelers, or alien residents. His point is that those who lend money to a government take their own risk of getting their money back; that it is bad for LatinAmerican governments to borrow so readily ; and that investors would be more careful if they did not expect the governments in the last resort to step in and compel their creditors to pay. If the Calvo Doctrine is sound, it binds the United States; 
but our government has never committed itself to this principle. In the Pan-American Congress of 1890 all the representatives, except those of the United States, voted for a declaration that foreigners should have the same status as citizens and the same legal protection for life and property, and no more. The United States delegates argued that it was the practice of governments to back up claims for unpaid public bonds and for forced loans and other oppressive acts of actual governments. The Latin-American states naturally favor Calvo's Doctrine, and at the Pan-American Congress of 1906 at Rio unanimously voted to -

" Consider the point of inviting the Second Peace Conference at The Hague, to consider the question of the compulsory collection of public debts, and, in general, tending to diminish among nations conflicts having an exclusively pecuniary origin."

The Conference of the Hague in 1907 went into this matter; but, as will be seen in the next section, committed itself to a milder form of statement.

\section{THE DRAGO DOCTRINE (1902-1915)}

A revised and limited version of the Calvo Doctrine was put forth December 29, 1902, in a dispatch written by Luis M. Drago, Foreign Minister of the Argentine Republic, and communicated to our State Department. The immediate occasion was the pending intervention in Venezuela :

"The collection of loans by military means implies territorial occupation to make them effective, and territorial occupation Territorial Occupation for Debts. signifies the suppression or subordination of the governments of the countries on which it is imposed.

"Such a situation seems obviously at variance with the principles many times proclaimed by the nations of America, and particularly with the Monroe doctrine, sustained and defended with so much zeal on all occasions by the United States, a doctrine to which the Argentine Republic has heretofore solemnly adhered.

“. . . The simplest way to the setting aside and easy ejectment of the rightful authorities by European governments is just this Territorial Expansion. way of financial interventions. . . . The Argentine Republic . . . would, with great satisfaction, see adopted . . . by . . . the United States . . . the principle, already accepted, that there can be no territorial expansion in America on the 
part of Europe, nor any oppression of the peoples of this continent, because an unfortunate financial situation may compel some one of them to postpone the fulfillment of its promises. In a word, the principle which she would like to see recognized is : that the public debt can not occasion armed intervention nor even the actual occupation of the territory of American nations by a European power.

"The right to forbid new colonial dominions within the limits of this continent has been many times admitted by the public men of England. To her sympathy is due, it may be European said, the great success which the Monroe doctrine Colonies. achieved immediately on its publication. But in very recent times there has been observed a marked tendency among the publicists and in the various expressions of European opinion to call attention to these countries as a suitable field for future territorial expansion."

The Drago Doctrine differs in many respects from the Calvo Doctrine. It is not simply the opinion of a text writer but an official proposal from one of the most responsible Latin-American States. It does not object to diplomatic action, but to the use of forcible measures, such as were at that moment in preparation against a Latin-American State. Another difference is that the Calvo Doctrine remains to this day a suggestion, while the Drago Doctrine has been approved by the United States and by the Hague Convention as a general principle of international law. After the Venezuelan trouble was all over President Roosevelt (February 15, 1905) said to the Senate: .

" Except for arbitrary wrong, done or sanctioned by superior authority, to persons or to vested property rights, the United States government, following its traditional usage in such cases, aims to go no further than the mere use of its good offices, a measure which frequently proves for Contract Claims. ineffective. On the other hand, there are governments which do sometimes take energetic action for the protection of their subjects in the enforcement of merely contractual claims, and thereupon American concessionaires, supported by powerful influences, make loud appeal to the United States government in similar cases for similar action. . . . Thus the attempted solution of the complex problem by the ordinary methods of diplomacy reacts injuriously upon the United States Government itself, and in a measure paralyzes the action of the Executive in the direction of a sound and consistent policy." 
At the Pan-American Conference at Rio in 1906, the United States delegates were instructed in favor of the Drago Doctrine by Secretary Root:

"It has long been the established policy of the United States not to use its armed forces for the collection of ordinary contract Force for debts due to its citizens by other governments. We Collecting have not considered the use of force for such a purDebts. sovereignty of othst wh sovereignty of other members of the family of nations which is the most important principle of international law and the chief protection of weak nations against the oppression of the strong. It seems to us that the practice is injurious in its general effect upon the relations of nations and upon the welfare of weak and disordered States, whose development ought to be encouraged in the interests of civilization; that it offers frequent temptation to bullying and oppression and to unnecessary and unjustifiable warfare."

The delegates were further instructed, however, to push for a reference of the whole question to the Second Hague Convention, where it was presented and defended by the representatives of the United States.

The Drago Doctrine if strictly interpreted might lead to the same results as the Calvo Doctrine; for if a delinquent power could not be coerced it might indefinitely refuse any kind of settlement. In the Hague Convention, therefore, a way was sought which would at least compel debtor States to show cause for refusing to pay their creditors. Dr. Drago was himself present and took part in the discussion and the conference finally came together (by a vote of 39 in favor and 5 abstentions) in the following statement, which became a part of the Hague Conventions of 1907.

“The contracting Powers agree not to have recourse to armed Arbitration force for the recovery of contract debts claimed from instead of Armed Force. another country as being due to its nationals. the Government of one country by the Government of

" This undertaking is, however, not applicable when the debtor State refuses or neglects to reply to an offer of arbitration, or, after accepting the offer, prevents any 'Compromis' from being agreed on, or, after the arbitration, fails to submit to the award."

The Hague Convention hoped by its action to make the Drago Doctrine a part of international law which would apply at all 
times all over the world; and it set up an international arbitration tribunal to which disputes could be submitted so as to carry out the second of the votes.

\section{THE AMERICAN DOCTRINE AND THE DRAGO DOCTRINE}

To test the new arbitral machinery and to lead the Latin-American States into the way of peaceful adjustment of their debts, the United States in 1902 brought before the Hague Tribunal the "Pious Fund" case, which was a long-standing controversy" with Mexico over a beneficiary fund for use in California. There was no danger of an invasion of Mexico on that issue, but it was a convenience to have the court decide in favor of the United States. In 1910, a less artificial case was made the claim of the Orinoco Steamship Company against Venezuela. The point was that this American corporation had been deprived of its concession for exclusive trade in certain rivers, for which damages it claimed $\$ 1,200,000$ and eventually the court awarded $\$ 92,000$.

The difficulty with the Drago Doctrine is that it settles nothing except that military expeditions shall not be undertaken for small reasons. As the Doctrine was finally stated in the Hague Conference, any European power has a right to demand arbitration of disputes over contract debts. It may also use diplomatic pressure; may combine with other powers to remonstrate and to threaten; and then, if arbitration is not forthcoming, it may still, - for all of Drago or the Hague Conference, - send ships, land troops, and hold a piece of territory until it gets satisfaction. The Drago Doctrine is only a lightning rod which carries off the electricity which may happen to strike within a limited area. It does nothing to prevent thunder-storms.

The real protection of Latin-American states from being assailed for comparatively light causes which do not involve the life and limb of aliens, is still outside of international law. Is the American Doctrine, as interpreted by Roosevelt in his messages on the Venezuela affair of 1902, such a protector? So long as there is no agreement between the Latin-American states that they will stand by each other in such controversies, their hope must be in the sincerity and good will of the United States; still further, they are dependent on our power to carry 
out the promises contained in the declarations of Presidents and Secretaries of State.

Further, the Calvo-Drago-Monroe Doctrine, when all dovetailed together, covers only a small portion of the possible sources of trouble. It does not offer a solution of revolutionary conditions such as those of Mexico. It does not affect the vast field of international difficulties caused by the presence of aliens in such revolutionary countries. The principle that a regular government shall not be responsible for the acts of a revolutionary body is a good one: people who deliberately place themselves in a revolution area must expect troubles. Yet what is to be done where there is a succession of revolutions and dictators? Which was the legitimate government and which the revolutionary, in the forty-eight alleged governments which existed in Venezuela between 1829 and 1861 ? 


\section{Chapter XVII \\ THE GERMAN DOCTRINE}

\section{AMERICAN COLONIZERS}

DURING the century of relations between the United States and Latin America, the problem has been simple because the number of foreign powers that had a right to share in the destinies of America was small. Holland and Denmark, although they still hold small American possessions, have never been a factor in American affairs. Russia withdrew official claim to territory south of $54^{\circ} 40^{\prime}$ in 1824 ; and though the posts on the coast of California were troublesome, they had ceased to have any political significance before the annexation of California. In 1867, by the cession of Alaska, Russia withdrew altogether from the American mainland and islands, including the Aleutian group which stretches westward almost to the coast of Kamchatka. The French since their withdrawal from Mexico in 1867 have pushed their investments and their colonial policy in other parts of the world. They have had fewer grievances against Latin-American states than some other great powers, and have been little concerned in the declarations, interventions, and protectorates by which the United States has enlightened the international history of America.

The one great power which since the decline of Spain has had a right to claim a large interest in America is Great Britain. Except for Guiana, that interest has been confined to North America and the adjacent waters. The West Indies have become a less important part of the world's trade and warfare than in the previous centuries; and the English part of the West Indies - Jamaica, Trinidad, and part of the Windward and Leeward Islands - have declined considerably in comparison with the larger West India Islands. The principal seat of the 
British power has been in the northern lands which are now brought together in the colony of Newfoundland and the Dominion of Canada. The Canadians are exceedingly loyal Britons, and in the Boer war of 1900 and the great European war of 1914, contributed men, money, and energy in profusion. Canada, however, is a semi-independent country, which on various occasions has brought pressure to bear upon the Imperial Government against making agreements with the United States which the Canadians disliked. At no time since the Civil War have the people of the United States felt that Canada was a seat of European power and influence.

\section{GERMANS AS COLONIZERS}

To Russia, France, and Great Britain during the last twentyfive years the great fields of colonial activity have not been in the western but in the eastern hemisphere: Africa, Asia, and Australasia. In those fields they have had to confront a new and determined colonizing power which has made itself felt also in America. This power is Germany, which might well be called one of the great colonizing nations of America because of the millions of Germans who have come out to become citizens of other countries. It is only since 1890 that this powerful nation has taken up the idea of colonies which should be owned and governed by Germans and which might include millions of native inhabitants who would not be consulted as to their governmental preferences. Inasmuch as Germany came late into the struggle for colonies, it was impossible to acquire desirable sites except by conquest from other powers. That method naturally seems to England, France, and Russia, with their enormous established colonies, as contrary to good breeding; and the United States is especially concerned lest the Germans should extend their ambition to South America.

That Germany is not included in the list of American colonial powers is almost an accident. The Emperor Charles V made grants of land on the northern and western coasts of South America to two of the great German banking families. As the time came for Spain, England, France, Holland, and Sweden to contend for empires in America, the Germans ought to have taken part, and they probably would have done so but for the calamity of the Thirty Years' War. In the year 1620, while 
the English Pilgrims were settling Plymouth, the Protestant Bohemians were overwhelmed at the battle of the White Hill. In 1630, while the Great Emigration was crossing the sea to Massachusetts, Gustavus Adolphus landed in northern Germany to head the northern Protestants. In 1638, while the New Englanders were talking about a Confederation, and the Swedes were planting a colony on the Delaware, the Protestants and Catholics were ravaging the interior of Germany. In 1648, when Rhode Island was striving to enter the New England Confederation, the Peace of Westphalia at last stopped the hostilities in exhausted Germany. Later wars and devastations and persecutions drove thousands of Germans to North America, but not an acre of territory in either western continent has ever owned allegiance to a German sovereign.

This ruin of Germany was a misfortune to America, for the Germans of the seventeenth century had the mental and moral outfit for colonization. They were good farmers, good craftsmen, good churchmen, strong, healthy, and well fitted to meet the hardships of colonization. They included a vigorous educated and literary class. They were good shipbuilders, good sailors, good navigators. Europe contained no better business men than the German merchants. For centuries previous to the Thirty Years' War they had maintained the German Hansa, the mightiest shipping trust ever known. If they had not spent their best blood on the barren battlefields of Germany, they could have reached the New World, explored it, colonized it, and held their own in naval warfare.

The Germans in this period founded some colonies. Bohemia was partly filled with Germans. Far down in Transylvania at various times German colonies were planted which still maintain their language, religious faith, and customs. Hundreds of thousands of Germans settled in northern Russia, and the great Catherine settled some of them in southern Russia, which was perhaps the original cradle of the Teutonic race. They could have set up a desirable community in any part of America where they found a footing. In the seventeenth century a footing was available in unsettled and disputed parts of North America. Yet with the exception of the unsuccessful venture of the Great Elector on the West Coast of Africa, the German flag previous to about 1890 never floated over any territory outside Europe. 


\section{GERMANS IN NORTH AMERICA}

Nevertheless Germans took considerable part in the English colonies. A few of them drifted into all the English settlements, and when William Penn published a tract in German, in which he set forth the attractions of "Quackerthal" in America, thousands of Germans heard the summons and came to Pennsylvania.

Other settlements were made by the Palatines in New York, and by the Salzburgers in Georgia, where Salzburg, Augusta, and Brunswick still recall the origin of those towns. German Swiss made a settlement at New Bern, North Carolina. Germans pushed out to the frontier, followed the valleys southwestward and spread into the Tennessee valley. Watauga, the pioneer European community on the headwaters of the Tennessee, was partly peopled by Germans. The stream of German immigration continued at intervals till the American Revolution. So far as can be judged from the census rolls of $1790,275,000$, or about one fourteenth of the total population of the United States as it then stood, were of German origin.

A second stream of Germans began to come into the country about 1820 , including some exiles of the highest intellectual power, and thousands of honest, hard-working citizens. The troubles of 1848 stimulated the exodus, and when the Civil War came on, many thousands of Germans born and their sons took up arms, especially on the Northern side. Some great cities, such as Philadelphia, Cincinnati, Milwaukee, Chicago, and Cleveland, have for years had a numerous and active German element.

The number of Germans in America is hard to estimate, because "German" may mean only men and women born in Germany; or it may mean individuals who consider themselves still Germans though for the time being living out of their country; or it may mean everybody.who is descended, however remotely, from an original German. The native Germans, in the United States in 1910, were about 2,500,000. They and the children of born Germans made up 8,300,000. The total number of persons who come of German stock, however remote, including the descendants of the Pennsylvania and other colonial Germans is about 15,000,000. 


\section{GERMANS IN SOUTH AMERICA}

In other parts of America, German colonists, except in the Argentine and Brazil, are hardly known. German business men, however, have been steadily coming in during the last twenty-five years. In most of the Latin-American countries, especially in Mexico, Venezuela, and Brazil they have set up banks, factories, mines, and import and export houses. German goods, German travelling men, German owners, and German experts are known throughout America; and their care to learn the language and the business methods of their customers has given them a great advantage. These business Germans in America carry with them their home distinctions of social classes and rank, and are not beloved by the people among whom they live. Through their energy in business and their ability to make money, many Germans have acquired property in American countries and have thus become objects of those unwelcome attentions from the heads of the state and their subordinates which lead to claims, protests, threats, and reprisals. Both in the Venezuela troubles of 1902 and the Mexican troubles of 1911, Germans suffered heavily. In Latin America there are supposed to be 600,000 Germans of whom 100,000 are in the Argentine and 500,000 in Brazil.

These last are the only ones that can lay claim to be something like a German colony in America. In the Argentine they are balanced by 1,000,000 Italians, and as many of other European races. In Brazil most of the Germans are settled in the southern provinces of Sao Paulo, Santa Catherina and Rio Grande Do -Sul, where they are the dominant element. They live together, keep up their language, and think of themselves as German-Brazilians and different from the Portuguese-Brazilians.

From the point of view of the present German imperial government, these people, like the Germans in the United States, are practically lost to their country. Many of them came away to get rid of military service and of a government which looked after them too faithfully. As a part of Brazil, they are persons of distinction, and they have as near local self-government as is possible in a country with the traditions of centralization. They are prosperous, increasing, and happy - so happy that they have never felt the need of calling upon their former home authorities to protect them against the Brazilian government. 
The only way in which they could ever serve German ambitions would be to pry themselves away from Brazil by revolution and then offer themselves as a colony of Germany. Whether this is a possibility no one can say. Many Germans in various parts of the world enjoy their freedom from paternal political control and bureaucracy. An independent German state, in which former Germans are predominant seems more likely than annexation to Germany.

\section{COLONIAL HOPES OF GERMANY}

Till 1890 Germany was willing to let her children go to build up other lands, for the population was rapidly growing and seemed too large for the land. The great change of sentiment since that date is due to a new plan for a national colonial system, for which Emperor William II and Admiral von Tirpitz are the persons most responsible. Captain Mahan had made it clear that sea power was the key to colonies, for the nation that could control the ocean could pick up its enemy's colonies whenever it was convenient. Colonies had become fashionable in Europe. The wealth of Holland is to a large degree derived from them. Belgium in 1907 took over the Congo region from the Crown. The French since 1840 have occupied three of the former Moslem countries in North Africa, and large areas in Africa and eastern Asia. Russia is colonizing Siberia; Italy has taken Tripoli ; England is the greatest colonial power of history.

The Germans wished to be admitted to this world's club of empires; and soon found that the qualification was the ownership of territory in which colonies could be founded. The Germans were late in reaching Africa, and could get only undesirable parts of that continent. They were late in Asia and succeeded in obtaining a foot-hold on the Chinese coast only by the seizure of Kiao Chao in 1898. To spread in Asia as other pioneers have done is now a hard task, for newcomers must reckon with the rising power of Japan and the mighty unorganized potentialities of China. In the last few years the Germans have picked up several groups of islands in the Pacific, and part of New Guinea. Undoubtedly they had their eyes upon the Philippine Islands, before and at the time of their annexation to the United States. 
The turning point in Germany's colonial situation was in 1906, when their minds were fixed on Morocco as a neat place for an African venture. They were blocked off at Algeciras by the combination of England and France, and the lesson was taken to heart. Thenceforward the Germans saw no way to secure really valuable colonies, except to take them by force. The main object of the war of 1914 between Germany and the western Allies is to test their sea-power, and to dispute their possessions of colonies. If the Germans are successful by sea and land, they will again occupy their colony in China, take their choice of African lands, and pocket such British naval stations, like Gibraltar and Egypt, as are thought necessary to protect the lines of communication. We shall know in a few months whether these ambitions are to be fulfilled.

\section{GERMANY IN VENEZUELA (1902)}

South America with its enormous, rich, and productive territories, little developed, and ruled by weak, despotic, and belligerent governments, has seemed a possible field for German colonization, especially in view of the scores of thousands of Germans in Brazil and Argentine. The chief obstacle has been, and still is, the attitude of the United States. Prince Bismarck once called the Monroe Doctrine "an American impertinence." Professor Adoph Wagner spoke of it as an "empty pretension." It was a natural inquiry whether it was not possible to be rid of those restrictions.

The only case of the appearance of German vessels in any port of America in a hostile frame of mind is the blockade of the Venezuelan coast in 1902. The Germans were undoubtedly ill-used by the South-American state and methodically set forth to the world three kinds of grievances. (1) They had suffered like other people from Venezuelan civil wars with their forced loans and requisitions and robbery of property; and they insisted strongly upon collecting these claims. Chancellor von Bülow remarked on this subject:

"Among German claims in Venezuela, we give precedence to those arising from the last Venezuelan civil wars. These are not mere business debts contracted by Venezuela, but they have grown out of acts of vio-

Claims for Damages by Civil War. lence against German citizens in Venezuela, either by forced loans 
or by seizure of cattle without payment, or by the pillage of German houses and estates."

(2) The Germans also demanded the payment of bond-holders and creditors in cases where the Venezuelan government had guaranteed payment. (3) The Germans complained that Venezuela had refused to take any action whatever which would lead to an adjustment of the claims by anybody except the officials of Venezuela.

These claims were real, were exasperating, and all ordinary remedies seemed to be exhausted. That Great Britain and Italy should join with Germany in the demonstration was an evidence that the three powers were convinced of the justice of their claim, and so far forth strengthened the case of all. Before actually sending out the expedition, Germany consulted the administration in Washington, and there was an exchange of personal letters between the Embassy and the Department and also between the German Emperor and the President. The German Chancellor made a distinct and clear statement of the purposes of Germany, December 11, 1901, in the following terms :

No Permanent Occupation.
"Under no circumstances do we consider in our proceedings the acquisition or the permanent occupation of Venezuelan territory."'

\section{Chancellor von Bülow also said in the Reichstag:}

"The Venezuelan matter was from the very first neither a question of territorial acquisition nor of glory for us, but of a

No Territorial acquisition for Germany in America. settlement through extraordinary means of business which had been complicated by the debtor's untrustworthiness, whereby, of course, the maintenance of honor played a part. We were able to establish our claim only through common action with England and Italy. It was not merely a question of arranging the matter in hand, but giving a warning which would serve for the future. The mere money standpoint must not control in such cases. We dare not submit to breaches of the law. Otherwise we would not need ships or cannons. The Venezuelan case was exceptional. We shall not always dispose of such matters through force, but our action will depend upon special circumstances."

Inasmuch as the United States had practically agreed not to oppose pressure that did not include occupation of territory 
the joint expedition had to use a kind of force that would not go beyond the high-water mark. They therefore took possession of the insignificant Venezuelan war craft; they sank some of those vessels; they bombarded Puerto Cabello; they declared a "pacific blockade" of all the Venezuelan ports. These acts very nearly amounted to war. However, the pledge was kept; the Venezuelans yielded, and the crisis was happily over. President Roosevelt intended it to be a warning to all Latin America that states could not do just as they liked and then call for the shield of the Monroe Doctrine. On the other hand the President used swift and sharp diplomacy in setting bounds to the methods of approaching Venezuela.

\section{GERMAN VIEWS OF THE MONROE DOCTRINE}

The impression in the United States was very strong that the German people and government were against us in the Spanish war of 1898; and there are many evidences that we have been looked upon by Germany as a power which stands in the way of the development of the Americas. A distinguished American statesman has said that Germany was the only country that he visited in Europe where he was made to feel that the whole spirit of the country was one of dislike toward the United States, because this country had become rich and powerful upon democratic methods which seemed to the German people contrary to greatness. The Emperor William has freely expressed his suspicion of a government in which congresses and legislatures are the ruling power. Among his sayings are:

"Parliamentarism is a double-edged sword, which now-a-days seems to do more harm than good."

"It is not talk, talk, talk, but do, do, do, that legislative bodies ought to be chiefly engaged in."

"After all it is the monarch alone which gives stability to the nation's politics."

\section{Of the country at large the Emperor has said :}

"Such a pushing people as the Americans will sooner or later clash with others. . . . Let us hope never with Germany."

"Your whole country is an experiment - an intensely interesting one, I admit. Whether it will stand the storms of time as the older monarchips of Europe have done remains still to be seen." 
Bismarck once called the Monroe Doctrine "a species of arrogance particular to the American and quite inexcusable." Professor Edouard Meyer in 1910 expressed a very unfavorable opinion of the Monroe Doctrine as follows:

"If, for example, the Monroe Doctrine were violated, the United States would appeal to the sword and not to The Hague. True, the United States does not own South America, yet they consider it to their advantage to keep other nations from gaining a foothold there. Inevitably this attitude must lead to war as the only solution."

The farthest point that Germany seems to have reached on this subject has been to recognize as a fact the peculiar interest of the United States in the future of Latin America. At the beginning of the European war in 1914, the German government lodged at the State Department a positive statement that they had no purpose of aequiring territory in America in connection with the European war. The Germans are a pragmatic people, who pride themselves on their knowledge of facts, their stores of information, and their remarkable power to apply exact knowledge to their problems. But they are not quick to understand the workings of other than German minds. To them the Monroe Doctrine is really a statement that the United States, from its commercial relations with other American States, would dislike it very much if they were colonized or otherwise affected by European powers; and that if an issue of sufficient importance were presented, the United States might go to war about it. In addition, many Germans think that the United States is playing fast and loose - warning others to respect the independence and sovereignty of the Latin-American States, and at the same time gobbling them up as dependencies or protectorates. This is one of the many forms of harm done by our persistent dollar diplomacy in Latin America.

\section{DANGER FROM GERMANY}

The significance to us of the intense desire and determination of the Germans to become a great colonial power is that they see nothing immoral in taking from England and France what England and France have within a few years taken from 
other people. The attitude of Germany to Belgium suggests that the Germans think it suitable to assume possession of any country which is of military or commercial advantage to them, and which they are strong enough to hold.

There is no evidence that the colonial conscience of Germany reawakes on this side of the ocean. If the Empire, now or hereafter, should fancy a colony in North or South America, it will not be held back by Monroe's Declaration that the "American continents, by the free and independent condition which they have assumed and maintained are henceforth not to be considered subjects for colonization by any European power." Hence the safety of Brazil and Venezuela does not depend upon their being entered upon the maps of the world as independent countries. Nor is the future of California or Texas secured simply by being geographically a part of the United States, but by the ultimate ability of the United States as a nation to hold on to them.

Americans in general believe that neither Germany nor any other power has the physical ability to invade or dismember the United States. None of the other independent American powers have the same confidence, and that is why they favor the American Doctrine so far as it protects them. No other of the World Powers seems at present in the least inclined to establish itself in America. Spain has lost all her colonies. France and England have all they can do to hold what they now possess. Italy is looking toward the Orient. Germany is the one power that has enough physical force and a broad enough ambition to give any chance of success in Latin America. Against Germany, therefore, more than any other nation on earth, all the American powers are seeking some rallying cry which would enable them to make head if danger came upon them.

$$
\text { [a. } \boldsymbol{l} \cdot \mathbf{c}]
$$

\section{THE AMERICAN DOCTRINE IN THE EUROPEAN WAR}

So potent is the American principle that it has cropped out in the fierce discussions caused by the European war. September 3, 1914, the German Ambassador at Washington, Count von Bernstorff, calmed an apprehension which had not been felt by sending a note to the Department of State in which he stated that - 
No German

Expansion

in South

America.
" $\mathrm{He}$ was instructed by his Government to deny most emphatically the rumors to the effect that Germany intends, in case she comes out victorious in the present war, to seek expansion in South America."

This statement was afterwards elaborated in public by Doctor Bernhard Dernburg, who was considered to be an unofficial representative of the German government :

"If the Government of the United States wants assurances from Germany that in the event of victory she will not seek expansion No German or colonization in North America, including Canada, Expansion and also South America, Germany will give the asin North or South

America. surances at once. Germany has not the slightest inDoctrine. ... .

"We have already laid before the Government of the United States an official note stating that Germany would not seek expansion in South America. North America was not included because it never entered our minds that any one could conceive that we had such intentions."

The Administration had not invited either of these statements, was not nervous about the possibilities of annexations by Germany, and did not make the Ambassador's communication public until it had been revealed by Dernburg. However, to these statements, which could in no way give offense, Dernburg added a warning about a part of America which has very seldom been mentioned in connection with the American Doctrine :

"The fact that Canada has taken part in this struggle has opened up a new prospective to Americans. It is a wilful breach of the Monroe Doctrine for an American self-governing dominion to go

\section{Breach of}

the Monroe

Doctrine in

Canada. to war, thereby exposing the American Continent to a counter-attack from Europe and risking to disarrange the present equilibrium. But I think America can set her mind to rest on that point. I at least would most emphatically say that no matter what happens the Monroe Doctrine will not be violated by Germany either in North America or in South America. When she is victorious there will be enough property of her antagonists lying about over the four parts of the globe to keep Germany from the necessity of looking any farther, and causing trouble where she seeks friendship and sympathy." 
This curious remark seems to point to a hazy idea that the Monroe Doctrine is something which, if disregarded, should call upon the culprit the disapprobation of the world. The point in Dr. Dernburg's mind is apparently that Canada was protected by the Monroe Doctrine (which it has never been), on an implied promise that Canada would keep out of European quarrels (which Canada has not done), and that by venturing across the ocean in defense of Great Britain, the Dominion has lost a sanctity (which it has never possessed). When the Canadians sent a force to the Boer War in 1900, it never occurred to the Germans that it was a breach either of international law or of the American Doctrine.

Almost the only thing which directly affects the American Doctrine in the European war, is the effort made by both sides to push or draw the United States out of neutrality and into a war in the causes and results of which she has only a distant interest. That is the penalty which the United States pays for acceptance of world power. The conquest of the Philippines, the share in the Open Door despatch, the Chinese intervention of 1900, and the agreement of 1908 to act in common with Japan on certain Asiatic questions, all commit the United States to a responsibility outside of America which cannot be reconciled with the old Doctrine of the Two Spheres. There are now three spheres of world action - West, East, and Near East - and the United States has a part in all of them.

In fact, the United States Government has a remarkable connection with the underlying causes of the present European struggle. In 1906, on the personal request of the Emperor of Germany, the United States sent Mr. Henry White as a representative to the European conference at Algeciras to decide whether Germany should have a foothold in Morocco. The influence of the American representative, acting under instructions from Washington, was very strong, and the United States must take part of the responsibility for shutting Germany out of this cherished ambition. If the United States feels an interest in Morocco, she cannot blame Germany for feeling an interest in Brazil. On the other hand, if the Germans have felt their exclusion from North Africa so keenly that they make it one of the causes for a terrible war, the United States would be equally justified in considering a German invasion of Brazil an act to be resisted by the American army and navy. 


\section{Chapter XVIII}

\section{PACIFIC AND ASIATIC DOCTRINES}

\section{EARLY AMERICAN INTEREST IN ASIA}

The late Professor Edward Bourne of Yale, used to say that the Philippine Islands were attached to the Spanish West Indies till after 1823, and therefore it ought to be presumed that Monroe intended his Doctrine to apply to that Asiatic archipelago. The quip leads the mind to the important fact that the relations of the Pacific Coast of America, the Pacific Ocean, and the nations of Asia, are all bound together. The first Asiatic trade went from Philadelphia, Boston, Providence, and other Atlantic ports via the Northwest Coast to China. The relation of the original Monroe Doctrine to Oregon is sufficiently described above. It is a curious fact that the objection to "colonization" which was intended to block the way of Russia, has been applied almost entirely to the West Indies and the eastern coast of North and South America. The clause in Monroe's Declaration had little to do with the process by which the United States came to have a Pacific front.

The three-cornered trade with a cargo of trinkets to the Northwest Coast, a cargo of furs to China, and a cargo of tea and silk and other Oriental products and some hard dollars, died down.as furs grew less abundant; but in the palmy days of the clipper ships there was a big trade "Round the Horn" to China and India, and the great islands off the southern coast of Asia. Quite a different trade was that of the whaling ships, which soon swarmed into the Pacific. The national service of the whalers was to put in at the Sandwich Islands and give their crews a little experience of society in the South Seas. They were followed by the missionaries, and the missionaries are chiefly responsible for the transition from the native 
kingdom of the Sandwich Islands to the present territory of Hawaii, as a part of the United States.

China was first reached by the ship Empress of China, in 1784, and the United States shared with other nations the scanty privileges of the port of Canton, till the British smashed a way for their opium trade in 1842 . The United States went up through the breach thus made, and, in 1844, secured a commercial treaty. Our diplomatic influence in China was for many years trifling, except that Anson Burlingame, when recalled by his own government, was taken up by the Chinese as their representative and negotiated the Treaty of 1868 .

Our entry into Japan has a curious connection with the proceedings in China. It was a happen-so that among several nations who were trying to get into communication with Japan, the United States should have won the prize. We now know that Perry and his fleet would have gone home unsuccessful but that a shrewd Japanese statesman called the attention of his court to the things that happened to China when that power refused to negotiate. Nevertheless, the conditions of the treaty of 1854 have pleased the dramatic instincts of both nations; and ministers, missionaries, and advisers from the United States have had an honorable part in the development of Japan.

\section{THE MONROVOID DOCTRINE ON HAWAII (1842-1849)}

Edgington, in his book on the Monroe Doctrine, repeatedly takes our government to task for not applying the Monroe Doctrine to the Pacific Islands. Not a single responsible official utterance can be found to show that any President or Secretary of State has ever tried to stretch the term Monroe Doctrine over that far distant area, which in Monroe's time was little known, little visited, little prized, and had little relation with Europe. Nevertheless, for many years the United States took a position with reference to Hawaii, which much resembles the Monroe Doctrine. In December, 1842, Secretary Webster made the following communication to commissioners who had appeared in Washington, asking for the recognition of the Hawaiian kingdom -

" The United States . . . are more interested in the fate of the islands and of their government than any other nation can be; and 
this consideration induces the President to be quite willing to declare, as the sense of the government of the United States, that No Coloniza- the government of the Sandwich Islands ought to be tion of the respected; that no power ought either to take posIslands.

session of the islands as a conquest, or for the purpose of colonization; and that no power ought to seek for any undue control over the existing government, or any exclusive privileges or preferences with it in matters of commerce."

These principles were restated in a special message to Congress by President Tyler -

"Considering therefore, that the United States possesses so large a share of the intercourse with those islands, it is deemed Protection not unfit to make the declaration that their Governby the United

States. anxiously wishes for its security and prosperity. Its forbearance in this respect, under the circumstances of the very large intercourse of their citizens with the islands, would justify this Government, should events hereafter arise to require it, in making a decided remonstrance against the adoption of an opposite policy by any other power."

Foster, Secretary of State under Benjamin Harrison, says of this declaration "The position assumed was in effect a virtual protectorate on the part of the United States." The next year the captain of a British ship of war engaged in a controversy with the monarchy and ran up the British flag, whereupon, believing that the assurances of the Secretary of State and President meant something, the King called upon the United States to intervene :

"Relying on the magnanimity and firmness of the United States, we appeal to the President to interpose the high influence

\section{High In-}

fluence of the U. S. of the United States with the Court of England to grant us an impartial hearing and procure us justice, to induce Her Britannic Majesty to withdraw from the sovereignty of these islands and leave us as we have been, an independent Government supported in our right."

The American ship of war Constellation soon appeared in the islands and remonstrated; and our Minister in London pro- 
tested; in 1843 Great Britain and France, both of whom had some designs on the island, made a joint agreement -

"To engage reciprocally to consider the Sandwich islands as an independent State and never to take possession, either directly or under the title of protectorate, or under any other form, of any part of the territory of which they are France and composed."

Meantime, the United States sent a minister to the Islands in 1843, but he forthwith found difficulty because the ministers of France and Great Britain obtained treaties by which subjects of France and England were not to be tried by a Hawaiian Court for a criminal offense. This was an application of one of the incidents of extraterritoriality, but under American influence the two European powers withdrew their claims to special privileges.

Trouble arose again in 1849 through a similar pressure upon the island by a French naval officer, and Secretary Clayton warned France not to interfere:

"The situation of the Sandwich Islands, in respect to our possessions on the Pacific and the bonds commercial and of other descriptions between them and the United States, No Euroare such that we could never with indifference allow pean Annexthem to pass under the dominion or exclusive control ation.

of any other power. We do not ourselves covet sovereignty over them. We would be content that they should remain under their present rulers."

\section{HAWAII IN THE UNITED STATES (1850-1915)}

The controversy led to an outright proposition of annexation, made to the United States. An official document transferring the sovereignty of Hawaii was drawn up in 1851, but Webster, again Secretary of State, was very cool to the proposition, and also to the plea that he was bound to take care of American citizens in Hawaii.

"You inform us that many American citizens have gone to settle in the islands; if so, they have ceased to be American citizens. The Government of the United States must, of course, feel an interest in them not extended to foreigners, but by the law of nations they have no right further to

Protection of American Citizens. 
demand the protection of this Government. Whatever aid or protection might under any circumstances be given them must be given, not as a matter of right on their part, but in consistency with the general policy and duty of the Government and its relations with friendly powers.

"You will therefore not encourage in them, nor indeed in any others, any idea or expectation that the islands will become annexed to the United States."

Further suggestions of annexation met with more favor in the eyes of Secretary Marcy, who, in 1853, made the following official statement :

"It has been intimated that Russia takes an interest in the destiny of the Sandwich Islands, and even has an eye on them for No Russia. herself. I do not doubt that she would prefer that they should remain as they are rather than see them under the control or in the possession of either Great Britain, France, or the United States, but it is scarcely probable that she would actively interfere in the matter."

Secretary Marcy laid down a principle which would apply the main restrictions of the Monroe Doctrine to the Pacific Ocean:

"I do not think the present Hawaiian Government can long remain in the hands of the present rulers or under the control of

\section{No Euro-} pean Protection. native inhabitants of these islands, and both England and France are apprised of our determination not to allow them to be owned by or to fall under the protection of these powers or of any other European nation.

"It seems to be inevitable that they must come under the control of this Government, and it would be but reasonable and fair that

\section{Annexation} Inevitable. these powers should acquiesce in such a disposition of them, provided the transference was effected by fair means. ... .

"This Government will receive the transfer of the sovereignty of the Sandwich Islands with all proper provisions relative to the existing rights and interests of the people thereof, such as are usual and appropriate to territorial sovereignty."

"The United States would not regard with unconcern an attempt on the part of any foreign power, and especially any European maritime power, to disturb the repose or interfere with the security of the Hawaiian Islands." 
Matters progressed to the actual drafting of a treaty, by which the Hawaiian Islands were to become a State of the Union; but it was never passed on by the United States Senate, and the matter cooled off.

From that time the United States cultivated friendly relations with Hawaii ; and American immigrants and their children came to have large influence in the kingdom. In 1875, a favorable reciprocity treaty was made with the Kingdom of Hawaii, which was thought by many people to be intended for the benefit of California sugar kings who wanted help in a fight with sugar trusts in the eastern States. In 1893 an impulsive minister to Hawaii did his best to bring about annexation by calling in marines, but he was disavowed by President Cleveland when he came into office, and annexation was postponed until 1898. Then Hawaii was annexed by joint resolution, and subsequently made a territory. There seems little prospect of statehood for a group of islands, in which only about 40,000 out of 200,000 are of the Caucasian race; of which 40,000, 24,000 are Portuguese and Spanish. Having been for several decades an unacknowledged protectorate, Hawaii has now become a dependency, which must expect for a very long time to receive its conditions and control from Washington.

\section{AMERICAN PACIFIC ISLANDS}

The social and political influence of Americans in Hawaii far exceeded any influence in the other Pacific groups. The United States government paid little attention to suggestions that other islands which had been first visited by our merchantmen or naval vessels ought to be declared permanent occupations, until 1898, when several such islands were taken up and incorporated into the map. The difficulty with Peru over the Lobos guano islands in 1852 arose out of a claim to the discovery of the islands by an American citizen in 1823, though they must have been known to the Spaniards three centuries earlier. American ships took temporary possession of Jarvis and Nantucket islands, in the Central Pacific, and of the Bird and Necker Islands in the neighborhood of Hawaii. In 1853, Commodore Perry suggested that he be authorized to take the Lew-Chew or Bonin Islands "under the surveillance of the American flag ", and he bought a coal depot there. 
His idea was to make this a center of American trading stations and colonies. Great Britain also laid claim to the islands, but they were annexed by Japan in 1878 .

The only other foothold of the United States in the Pacific previous to 1898 was an undivided share in the Samoan Islands. Inasmuch as the Germans and British were firmly seated as traders in those islands and the home countries pressed territorial claims, it was not possible to apply the idea of a sole protectorate. The United States, therefore, by a treaty of 1889 , agreed to a triple joint protectorate which worked very ill ; and, in 1899, there was a territorial division of the islands, in which the United States took unquestioned title to Tutuila, with its splendid port of Pago-Pago, and five small islands near by. The group is governed by the President and the Navy Department, and there seems no prospect that it will ever come into even the territorial condition.

\section{AMERICAN PROTECTORATE OF LIBERIA}

Far away from the Pacific and Asia is the little country of Liberia, which is the only portion of Africa in which the United States has a direct interest. In an area of 40,000 square miles live perhaps $2,000,000$ people, of whom about 12,000 are descendants of immigrants from the United States, and about 40,000 more are partly civilized and Christianized. The Republic of Liberia goes back to settlements made by the American Colonization Society for negroes returned to Africa. Various little plantations were combined into one community in 1837; and in 1847 Liberia declared itself sovereign and independent. In 1862 the United States formally recognized the nation and exchanged ministers; and in 1884 Secretary Frelinghuysen said of it:

"Although at no time a colony of this government, it began its career among the family of independent states as an off-shoot of this country, and as such entitled to the sympathy and, when practicable, the protection and encouragement of the United States . . . a relationship of quasi-parentage."

December, 1886, President Cleveland said of it:

"It can not be forgotten that this distant community is an offshoot of our own system, owing its origin to the associated 
benevolence of American citizens, whose praiseworthy efforts to create a nucleus of civilization in the Dark Continent have commanded respect and sympathy everywhere, especially in this country. Although a formal protectorate over Liberia is contrary to our traditional policy, the moral right and duty of the United States

Informal

Protectorate over Liberia. to assist in all proper ways in the maintenance of its integrity is obvious, and has been consistently announced during nearly half a century."

This situation, which has never been officially recognized by the United States or other countries, puts Liberia for the time being out of the hurly-burly of African territorial struggles, and it may develop into a regular colony of the United States. The only direct bearing of Liberia on the Monroe Doctrine is that it is one of several indications that the United States cannot in the nature of things, keep out of the Eastern sphere of human affairs.

\section{AMERICAN POLICY IN ASIA}

The interest of the United States in Asia was first of all commercial, then religious, and much later territorial. In 1831 an American ship was sent out to bombard the pirate town of Quallah Battoo. Four naval expeditions were sent to Japan before Perry was successful. American forces were four times landed in China between 1854 and 1859 to protect life and property; and again in 1900 . None of these expeditions and landings were based upon an acknowledged theory of the relation of the United States to Asia. In China and Japan, when those countries were first opened to foreigners, the idea of inferior nations was practically applied by the system of extraterritoriality. Since the laws, customs, and courts of those countries were not adjusted to Western ways, both the Asiatic and external governments were led to believe that foreigners should live in a restricted area and should provide courts for their own affairs and offenses.

When Japan modernized itself, building up a representative government, skilled courts, and codes of laws, the system grew irksome and the United States led in a movement to give up the privilege in 1899. This amounts to a frank admission that Japan is a full nation in the Western sense, not subject to any limitations or deductions. In China the system of extraterri- 
toriality still prevails except that foreigners are no longer confined to certain "concessions" for residence. In those concessions Chinese subjects are taken out of the jurisdiction of their own magistrates upon certain questions and are triable in "mixed courts", in which a foreign consul or his representative has the deciding voice.

In most of the rest of Asia, the United States deals with colonies whose affairs are decided by European governments. In Siam there has been a strong American influence, because two successive advisers to the King of Siam, Dr. Strobel and Professor Westengard, have had such influence that they have jocularly been called "American Kings of Siam." The late Mr. Dennison was for many years the trusted counsellor of Japan in diplomatic affairs, and John W. Foster was so highly regarded by China that in 1895 they brought him over to be the associate with Li Hung Chang in negotiating peace with Japan.

In general, the influence of American diplomats, statesmen, and missionaries has been one of friendship, both with China and Japan. This is creditable to the three nations concerned, and is greatly aided by the fact that there seems to be no territory or point of vantage which is desired by Japan or China on one side, and by the United States on the other side. The Japanese were disturbed about the annexation of the Hawaiian Islands, in which 80,000 Japanese have their homes, but that is an accomplished fact. Controversies between Oriental countries and the United States have of late years principally concerned immigration and citizenship, which have little connection with territorial questions.

\section{PROTECTION OF THE PHILIPPINE ISLANDS}

Ever since the ratification of the treaty of annexation in 1899 the Philippines have been an indisputable part of the American Empire, for, by the insular decisions of 1900, the Supreme Court affirmed that they were no longer foreign territory ; but, till Congress should act, they would not come within the customs boundary or the sphere of general acts of Congress. The possession of territory only six hundred miles from Hong Kong and centrally situated for Pacific trade puts the United States in the category of external nations which own colonies in Asia. 
From the first there was a strong protest in the United States against annexation and then against permanent holding as a dependency. As a possession, the Philippines are entitled to defense by their over-country. Should the plans for an independent republic be successful, the new government will either be actually independent, or will be fastened down by obligations like those laid upon Cuba. While the Filipinos feel perfectly competent to navigate for themselves in the stormy political seas of the Western Pacific, it is plain that they have neither numbers, means, unity, nor training sufficient to defend themselves against the European colonizing powers, or Japan, or China.

To hold the people against their will as a dependent part of the Union is contrary to American principles of government; to set them afloat as an independent nation would be to invite war and conquest. To give them independence while requiring that their defense and foreign policy be regulated by the United States, would leave them protectorates. To cover them the United States would be obliged to extend to the Pacific the principle which in America is called the American Doctrine. Foreign powers are to be warned off that section of the ocean. The United States is to guarantee the archipelago protection from invasion and from interference with its government. This is "colonization" and "political system" over again.

President Taft, earlier Governor-General of the Philippine Islands, looked forward to ultimate independence. President Wilson comes nearer the main issue, though he does not solve the critical question whether the United States is really to allow the Filipinos to work out their own destiny. Soon after he became President he expressed his mind on the question of independence as follows :

" Porto Rico, Hawaii, the Philippines, are ours, indeed, but not ours to do what we please with. Such territories, once regarded as mere possessions, are no longer to be selfishly exploited; they are part of the domain of public conscience and of serviceable and enlightened statesmanship. We must administer them for the people Responsibility to Porto Rico and Hawaii. who live in them and with the same sense of responsibility to them as toward our own people in our domestic affairs. No doubt we shall successfully enough bind Porto Rico and the Hawaiian Islands to ourselves by ties of justice and interest and affection... . 
In the Philippines we must go further. We must hold steadily

Independence of the Philippines. in view their ultimate independence, and we must move toward the time of that independence as steadily as the way can be cleared and the foundations thought-

\section{FOUNDATIONS OF AN ASIATIC DOCTRINE}

Wu Ting Fang, then the talented Minister of China to Washington, some years ago suggested that -

"The Monroe Doctrine, being the fixed policy of your government, the natural logic is that it should be applied to that part of the world where this country has possessions."

There is something in this quip; for though the Monroe Doctrine can hardly take passage across the Pacific, the question of the "paramount interest" of the United States may well apply. Conditions of Eastern Asia to-day much resemble those of South America a century ago: on one side a weak and disorganized race; on the other, active and hungry European powers. Instead of a group of small states, there is the one great Empire of China, to which the European States have long since applied their "political system, controlling its destinies." They have chipped off numerous fragments of Chinese territory: Manchuria, part of Mongolia, Dalny, Port Arthur, Wei-Hai-Wei, the German colony of Tsin-Tau, Hong Kong and Kow Loon across the strait, the French possession of Kwang-Chau-Wang. Intervention by single European powers, and commands issued by groups of powers, have been the long experience of the Chinese.

The country is peopled by one race, and has one set of customs and traditions, including that of a unifying empire. The Chinese have been in past history a conquering race. They are a commercial people and they possess probably the richest mineral resources in all the world. Yet the old Empire and the present Republic are unable to shake off the influence of external powers. In any case, the United States is not in a position to terrorize China or any part of Asia. The principal reason why Americans are in China and interested in it are either a missionary zeal or commercial reasons. Nobody would dream of attaching China to the American system, or applying to it any form of the American Doctrine. 


\section{AMERICAN PRINCIPLE OF THE OPEN DOOR}

It has nevertheless been in the power of the United States to give China great and needed aid by proposing a sort of commercial Monroe Doctrine for that Empire. In 1898 four ambitious great European powers seized different pieces of Chinese territory, and then they began to squabble about their rights in the interior. They seemed to think that it was in their power to subdivide China into European colonies or at least into "spheres of influence." Russia was to have a free hand in the North; England in the Yang-tse Valley, France in the South, and so on. The United States, through her occupation of the Philippines, was a near neighbor to these schemes, and John Hay was Secretary of State. He was the only man in the world who set himself to the problem of saving China from disruption, without a general war. In 1899, he drew up and - sent to all the powers concerned a circular upon Chinese trade to which the term "Open Door" has ever since been applied.

"First. The recognition that no power will in any way interfere with any treaty port or any vested interest within any leased territory or within any socalled 'sphere of interest' it may have in China.

No Interference with Vested Interests.

"Second. That the Chinese treaty tariff of the time being shall apply to all merchandise landed or shipped to all such ports as are within said 'sphere of interest.' . .

"Third. That it will levy no higher harbor dues on vessels of another nationality frequenting any port in such 'sphere' than shall be levied on vessels of its own nationality, and no higher railroad charges over lines built, controlled, or operated within its 'sphere.'"

This despatch so completely met the situation that it was accepted with brief delay by all the powers concerned, including Germany. Hay's point is very simple: no nation is to be allowed to come in and, on the plea of possessing "a sphere of influence", disturb the established trade with China, in which all nations have a right to share. It expresses the spirit of the Monroe Doctrine, in what is substantially a protest against colonization by European powers, and also against the introduction of a commercial system which comes perilously near being a "political system."

No one knows what will be the effect of the present European 
war upon China. For many years the ambassadors from Europe have been a check upon each other, each watching sharply to see that his neighbor gets no more in the way of concessions and opportunities than his own countrymen. On the other hand, the European powers have long stood by each other in Oriental relations. They were able to engineer even so complicated a situation as the joint expedition to Peking in 1900. It looks as though that concert was broken up, so that China must henceforth deal single-handed with her most powerful immediate neighbors, Russia and Japan.

\section{DUAL UNDERSTANDING WITH JAPAN (1908)}

The war of 1904-1905 left Japan in Manchuria alongside China and it became evident that the Japanese were laying the foundations for control of the railroads which were feeders of the Chinese system, and for a special influence on internal trade. Secretary Root in conference with President Roosevelt decided to keep up the general method pursued in the Open Door despatches. Under date of November 30, 1908, he negotiated with Japan a note which was never submitted for ratification by the Senate, in the following terms:

"1. It is the wish of the two Governments to encourage the free and peaceful development of their commerce on the Pacific Ocean.

"2. The policy of both Governments, uninfluenced by any aggressive tendencies, is directed to the maintenance of the existing status quo in the region above mentioned and to the defense of the principle of equal opportunity for commerce and industry in China.

" 3 . They are accordingly firmly resolved reciprocally to respect the territorial possessions belonging to each other in said region.

" 4 . They are also determined to preserve the common interest of all powers in China by supporting by all pacific means at their disposal the independence and integrity of China and the principle of equal opportunity for commerce and industry of all nations in that Empire.

" 5 . Should any event occur threatening the status quo as above described or the principle of equal opportunity as above defined, it remains for the two Governments to communicate with each other in order to arrive at an understanding as to what measures they may consider it useful to take." 
The form and purpose of this note are almost without parallel in American diplomacy. It assumes a special interest in China on this side of the water; it accepts a partnership with Japan; it includes a promise that neither power will take action in China without consulting the other. In some ways it resembles the Clayton-Bulwer Treaty, in that the two powers concerned assert their special fitness to adjust a serious question together.

In the next administration Secretary Knox tried his hand on the Chinese question. In 1909-1910 he sent a note protesting against the situation of Russia and Japan in Manchuria and suggested a course of action which he thought would remedy the trouble, but no attention was paid to this recommendation, of which the essential passages are as follows:

"The Government of the United States asks his Britannic Majesty's Government to give their consideration to the following alternative and more comprehensive projects: First, perhaps the most effective way to preserve the undisturbed enjoyment by China of all political rights in Manchuria and to promote the development of those Provinces under a practical application of the policy of the open door and equal commercial opportunity would be to bring the Manchurian highways, the railroads, under an economic, scientific, and impartial administration by some plan vesting in China the ownership of the railroads through funds furnished for that purpose by the interested powers willing to participate. . . . The plan should provide that nationals of the participating powers should supervise the railroad system during the term of the loan and the governments concerned should enjoy for such period the usual preferences for their nationals and materials upon an equitable basis inter se. The execution of such a plan would naturally require the coöperation of China and of Japan and Russia, . . . as well as that of Great Britain and the United States. . . . The advantages of such a plan to Japan and to Russia are obvious. Both those powers, desiring in good faith to protect the policy of the open door and equal opportunity in Manchuria and wishing to assure to China unimpaired sovereignty, might well be expected to welcome an opportunity to shift the separate duties, responsibilities, and expenses they have undertaken in the protection of their respective commercial and other interests, for impartial assumption by the combined powers, including themselves, in proportion to their interests. . . . The principle involved in the foregoing suggestions . . . finds support in the additional reasons that the consummation of such plan ... would create such a community of substantial interest in China as would facilitate a 
coöperation calculated to simplify the problems of fiscal and monetary reforms now receiving such earnest attention by the Imperial Chinese Government."

\section{JAPANESE TESTS OF THE AMERICAN DOCTRINE}

Though the American Doctrine does not reach to Asia, it is quite possible for Asia to reach to America. It is fortunate for the United States that China has been in no position to back up claims for the reception and citizenship of her subjects in the United States; for what threatened thirty years ago to be a crisis has been removed by the simple stoppage of the immigration of laborers, without interrupting the friendship of the two nations. Japan enters much more deeply into American questions, having a great military and naval power, carrying on trans-Pacific commerce in Japanese ships, possessing an active population, thousands of whom would like to settle in the United States.

Down to the successful war of Japan against Russia, nobody thought of the Japanese in connection with the American Doctrine. Their victory, or at least equality, in that struggle caused Japan to be accepted as one of the world's great powers. If the Japanese at any time should cherish designs upon American territory similar to those of the Holy Alliance in 1823, there would be a time and place for evolving a new doctrine, parallel in scope with the original Monroe Doctrine.

On this side of the Pacific, the Japanese have learned that the United States may not precisely apply the Monroe Doctrine to them, but does apply exactly the same basal principle. The great objection to allowing Japanese laborers to come to the United States is that they might found what would practically be a Japanese colony. The people of the Pacific Coast believe that the Japanese government, if need arose, would call upon such Japanese settlement to stand by their Empire; exactly as Germany may sometime ask the Germans in Rio Grande do Sul to stand by their original land.

The Magdalena Bay Episode of 1912, described in an earlier chapter, raised a more direct issue. Of course the assurance of the Japanese Government must be accepted, that no territory had been acquired at Magdalena Bay by any Japanese with or without the consent of Mexico. Nevertheless, the 
belief remains that if nothing had been said about the matter, if the United States had gone on her way without remonstrance, the Japanese government would soon have been in possession of a coaling station on the Mexican coast. The United States stands firm against any right of the Japanese to plant a station on the west coast of Mexico, and at the same time is trying to get islands lying off the coast of Central America, for a like purpose. A Japanese station in America cannot be allowed; but we hold the large group of the Philippines, with its 8,000,000 people, just off the Asiatic coast, and near neighbor to Japan.

The opposition of the United States to any Japanese territorial hold anywhere on the eastern side of the Pacific may not be logical, but it is firm, and has its basis in the interests of this country. Japan is nearer to Western Alaska than is the State of Washington. Japan is but a few hours' sail from the Philippines, and a few days' sail from the coast of California. That nearness and the military and naval power of Japan make it necessary for the United States to apply to Asiatic influence in America the same principle that she maintains with regard to European interests. So far as the Monroe Doctrine has force and meaning and reason, it is as good against Asia as against Europe. The time may come when it will be asserted against Australia. The true American Doctrine is directed, not against this or that power, but against a state of foreign mind, unfavorable to the interests of the United States in America.

\section{JAPAN'S MONROE DOCTRINE FOR ASIA}

The effect of the joint note was tested when the war broke out in 1914, and Japan as one of the western allies prepared to besiege Tsin-Tau. Official notice was given to the United States government that it was the intention of Japan to return that province to China. After its capture, no steps were taken in that direction and the world was soon informed that the Japanese were pushing upon the Chinese a treaty which would give them a specially privileged position in China. The Japanese were to have extensive rights of trade, the ownership and management of certain mines and railroads, and positions as "controlling advisers" in police and financial departments. The Japanese by a whimsical situation have long been Europeans in China; that is, they are entitled to the privileges of 
extraterritoriality, and they have pushed those privileges far. The recent demands, many of which have been embodied in a treaty, seem intended to put Japan in about the same position toward China, as that in which the United States is placed with regard to Cuba. If the treaty holds, henceforth nothing serious can be done by the Chinese government without the good will, if not the formal approval, of Japan.

Considering that Japan has 53,000,000 people, besides Korea and Formosa, and China has between 300,000,000 and $400,000,000$, the responsibility assumed by Japan is portentous. Japan is claiming in the whole of the Middle Kingdom a "Sphere of Influence" far wider than was expected by the great powers, when disturbed by the Open Door despatch of 1899. Japan's preferences in trade seem likely to destroy that equality which was the basis of Hay's theory. Japan is laying up a legacy of distrust and hatred which may take the place of the fear and fury often felt by Chinese toward Europeans. It remains to be seen whether, when the present European war is over, Europe will accept this dictum, or will be in a situation effectively to protest.

Nothing in the future can be more certain than that Japan henceforth will stand against all countries as the leader of the Asiatic spirit and the defender of Asiatic empire in Eastern Asia, - exactly as the United States feels herself the champion of true Americanism in the Western Hemisphere. Perhaps it is fortunate for all the western powers that China and Japan have shown that they will not pool their issues, and go forward hand in hand as the dual great power of Eastern Asia. Like Latin America, Asia is deprived of the influence in the world which its numbers and civilization would permit; it suffers from the same inability of men of kindred race to act together. 


\section{PART V \\ PRESENT WORLD CONDITIONS}

\section{Chapter XIX}

\section{CHANGES OF WORLD CONDITIONS}

\section{PROGRESSIVENESS OF THE AMERICAN DOCTRINE}

THE preceding survey of the American Doctrine as seen through the eyes of other people leaves the impression that not only is the present Doctrine viewed with suspicion in Latin America, Europe, and Asia, but that the United States has no very clear idea of what it means, how far it applies, and how it is to be sustained. So many things have been called "Monroe Doctrine" which do not agree with each other, and so many Presidents, Secretaries of State, and other men of weight have put forward such a variety of reasons for what they claim to be the real Simon-pure Monroe Doctrine, that the tendency is to lose sight of the two main principles of every vital form of the Doctrine. The first is that the Doctrine has always been and is now, directed primarily to the defense and welfare of the United States, and secondarily to the defense and welfare of other American states. The second is that the Monroe Doctrine has taken various shapes because the conditions upon which it rests have shifted from decade to decade. That would be a good reason for disusing the term "Monroe Doctrine", except that everybody recognizes those two words as meaning, in broad form, a paramount interest of the United States in America.

In spite of the efforts of Fish and Olney and Root to make out that there is an unchangeable Monroe Doctrine, a law of the Medes and Persians, which altereth not, it would be impossible to apply the comparatively simple original form of statement to the complicated conditions of the present day. Modern science and philosophy and history have accepted the Darwinian theory of development. The world to-day reasons on a presumption of change. The present European war is held by Germany to be due to the refusal of other nations to recognize the German 
right to seek new advantages. The struggle has been notable for the appeals of the belligerents to neutrals and to each other to accept the fact that warfare and international usages have changed and must necessarily change. They insist that the advance of science has so altered weapons and the art of war, that the former international law of contraband and blockade and neutral shipments no longer covers the cases that arise.

Many examples prove that this principle of change undermines the policies and axioms of nations. For centuries there was a tradition that England and France must be natural enemies; now they are firmly bound allies. It is only seventeen years since Rudyard Kipling warned his countrymen against the Russian bear; at present he strokes the shaggy animal's fur and only wishes that he had more teeth. The United States for decades carefully forbore to exert any influence upon the governments of her neighbors, and now practically dictates to half a dozen of them.

It is time to give up what has long been a kind of Monroe Doctrine cult. The journalist, the diplomat, and the public man seem to find something sacred in the phrase and in the policy. Such unthinking adoration is difficult to maintain, in view of the fact that neither the Doctrine nor its bases are now what they were a century ago when the question first arose. Conditions both in Europe and America have fundamentally changed. To the soldier, the writer, and above all, the statesman, it is of consequence to know what the political department of the government and the public sentiment of the country believe that the Doctrine now includes. Reddaway, the English authority on the Monroe Doctrine, sees clearly the mind of the American people in the matter :

"As against their own Government, their neighbours and Europe, they are wont, therefore, to gain every point upon which

Americans not bound by their Own Doctrine. they insist. Hence they must inevitably tend to exalt their own authority, and to believe that their will has only to manifest itself to be obeyed. Such a people, it is clear, cannot be fettered by ancestral maxims which do not commend themselves to their present judgment. . . . From the time when its promulgators went out of office, the Monroe Doctrine, if heeded at all as a canon of policy, must from the nature of the case have been applied with progressive meaning." 
A still more facile way of dealing with the changes in the Monroe Doctrine was expressed by President Adams, of Wisconsin, in 1896 :

"It may justly be said, that, as the Monroe doctrine is to be defended and upheld, not as a part of International Law, but simply as an American policy; so, if the people demand it, it Right to can as easily and as logically be modified and ex- Modify. tended as in the beginning it could be formulated and promulgated. What we had a right to create, we now have a right to modify."

\section{EXPONENTS OF CHANGED POINTS OF VIEW}

The Monroe Doctrine was made by fate, and has grown to meet world forces, but its form has been much affected by those who have from time to time stated it; and they have steadily changed the national point of view. Most of them have been men of ability. John Quincy Adams was the equal of any later Secretary of State, even of John Hay. President Polk was as eager to shape a national policy as President Roosevelt. The difference of form of statement is not in the capacity of Presidents and Secretaries of State, but in the widening of their fields. The group of five European great powers which impressed Monroe with their might were children compared to the modern great nations. The other group of weak, small, and distressed communities whose dangers aroused him had together less influence in the world than that now possessed by the Argentine alone. Modern statesmen have been compelled to view the world in a larger way, to extend their interests and their knowledge. The desk of Secretary Lansing has probably five times as many kinds of business lying upon it as that of Secretary Madison or Secretary Cass.

With few exceptions all the long line of worthies who have put forward successive statements on American relations, have been sincere, patriotic, and clear-headed. Jefferson, Monroe, John Quincy Adams, Seward, Grant, Fish, Evarts, Blaine, Cleveland, Hay, Root, Roosevelt, Taft, Wilson - all have meant something definite by what most of them called the Monroe Doctrine; all have recognized the critical point that our policy toward Latin America does not coincide with our general policy toward external nations, and therefore needs 
defense. Yet all have different ideas each from the other, different surroundings, and a different output of doctrine.

Among the persons who have most contributed to the successive layers of the Monroe Doctrine are John Quincy Adams, who was the draftsman, and, to a large extent, the originator of the declaration of 1823 . James K. Polk was the first to face the problem of forbidding European nations to do to LatinAmerican states what we were willing to do; Seward laid the foundation of our later canal policy; Blaine was the first to discover the possibilities and difficulties in persuading the Latin-American states to do something for their own protection; Olney pungently stated the dangerous boomerang doctrine that the United States might do what she chose in America and call upon the Monroe Doctrine to sustain her. Roosevelt broke through the vicious circle resulting from the insistence of LatinAmerican powers that they were free from accountability to other nations; Wilson has pushed very far the method of removing the difficulties of little powers by removing their independence. Not one of those statesmen felt that his predecessors had expressed the full truth, or had recognized completely the circumstance which made a new announcement necessary. Each added a new story to the structure.

\section{CHANGES IN TERRITORIAL CONDITIONS}

The most obvious alteration since 1823 is in the political geography of the world, which has brought new problems everywhere and particularly in America. Three new continents have practically been opened up, - Asia (especially the outlying archipelago of Japan), Australasia, and Africa. New British, French, and German neighbors have also appeared in the Pacific islands. Fast steamers, regular intercourse, cables, and wireless, have brought the ends of the earth nearer, and have powerfully aided in breaking down the now obsolete Doctrine of the Two Spheres. New neighbors to the westward feel a keen interest in our American policy. New problems of external defense hamper the efforts to state a fixed policy. World changes of boundary, world growth of new empires, alter our horizon and restrain our acts.

Within America the number and grouping of states has greatly changed in a century, as may be seen by the following tabulation. 
A. Number of American States in 1823.

1. United States of America (then bounded on the West by the Sabine River and Rocky Mountains) together with claims to Oregon.

2. Six continental States, formerly Spanish.

(Mexico; Central America; New Granada; Peru; Chile; Buenos Ayres.)

3. One continental State, formerly Portuguese.

(Brazil - in 1823 temporarily including Uruguay.)

4. One island republic, formerly Spanish and French.

(Haiti, of which Santo Domingo was at the time a part.)

5. Seven groups of colonial possessions of European powers.

(a) British possessions. - Canada ; Hudson's Bay Company ;

Oregon claims; Nova Scotia and New Brunswick; northeastern islands; Jamaica; several groups of West India islands; Belize; Guiana.

(b) French possessions. - islands in the Windward and Leeward groups; Guiana; the little islands of St. Pierre and Miquelon.

(c) Dutch possessions. - Surinam and a few small West India islands.

(d) Danish possessions. - a small group of West India islands.

(e) Russian possessions. - Alaska, claiming south of present boundaries.

(f) Spanish possessions. - Cuba and Porto Rico.

(g) Swedish possessions. - St. Bartholomew.

Total American powers in 1823: seventeen in all.

(a) 10 independent American States.

(b) 7 colonial groups.

B. Number of American States in 1915.

1. United States: (extended to the Pacific, with additions of Alaska, the Hawaiian Islands, and Porto Rico).

2. Four leading Latin-American States:

(a) Mexico (much reduced in territory).

(b) Brazil.

(c) Argentine (having lost Uruguay and Bolivia).

(d) Chile.

3. Four potentially strong States :

(Venezuela ; Colombiá; Peru; Uruguay).

4. Seven feeble States :

(Honduras ; El Salvador ; Costa Rica ; Ecuador; Bolivia ; Paraguay; Guatemala).

5. One acknowledged protectorate of the United States :

(Cuba). 
6. Four virtual protectorates of the United States :

(Santo Domingo; Haiti ; Panama ; Nicaragua).

7. Four groups of colonial possessions :

(a) British possessions. - as in 1823, with the addition of complete title to British Columbia, and formal annexations in the far North.

(b) French possessions. - as in 1823, plus St. Bartholomew.

(c) Dutch possessions. - as in 1823.

(d) Danish possessions. - as in 1823.

8. Total American Powers in 1915; twenty-five in all :

(a) 16 independent States.

(b) 5 protectorates of the United States.

(c) 4 colonial groups.

C. Relative population in 1823 and 1915 .

\begin{tabular}{|c|c|c|c|c|}
\hline & LATin AMERica & United States & OTHERS & TotaL \\
\hline 1823 & 22 million & 11 million & 1 million & 34 million \\
\hline 1915 & 75 million & 100 million & 10 million & 185 million \\
\hline
\end{tabular}

A little study of these figures will bring out the significance of the changes. A hundred years ago Latin America had twice the population of the United States; now it has about three fourths our present population. There is no single LatinAmerican power that would dream of attacking its great neighbor, or that could safely go to war with any one of the six great powers of Europe, or Spain, or Japan. The only strong group, the $\mathrm{A} \mathrm{B} \mathrm{C}$, has a present population of thirty-five millions, and could not think of disputing supremacy with the United States unless that power were hard beset by extra-American enemies. In 1823 Spain still claimed every revolted colony; France had hardly given up lingering hopes of recovering Haiti; Russia was pressing on the northwest. All those external influences have long since been extinct. Nobody expects either France, Spain, or Russia to make any attempt to seize Latin-American territory.

The most startling change on the map is the annexation of Texas, New Mexico, California, the Gadsden Purchase, Porto Rico, and the Canal Zone by the United States; for all of them came out of the wreck of the Spanish Empire, and all but Porto Rico have been parts of some independent American power. 
By these annexations the United States has become possessed of a multitude of vantage points for commerce and defense. After waiting a weary century, she has obtained a foothold in the Caribbean Sea by the ownership of Porto Rico and is steadily pushing her influence in that region.

In all these changes there is no encouragement for European colonization, which was a real danger a hundred years ago. Cuba, the Mosquito Coast, Tigre Island, and Mexico have been coveted by foreign powers, but the only territory in foreign hands is Belize. Up to the present time the United States has never lost a point in her controversies over territory, whether they were settled by negotiation, arbitration, or annexation; with the single exception of Blaine's futile claim to a closed sea alongside Alaska. The whole trend of the geographical history of the century has been in favor of the main principle of the Monroe Doctrine.

\section{PRESENT TERRITORIAL FIELD}

How far have changing conditions altered the geographical application of the old-time Monroe Doctrine? The phrase applies only to the Western Hemisphere, but it no longer rests on the Doctrine of the Two Spheres. Its basis is simply that the United States, as the richest, most populous, and most forthputting community in America, takes upon herself a special interest in American affairs, which she would share with no other power. The United States has done more than any one else to define a restricted area for her doctrine:

(1) The United States herself has never been considered in the Monroe field, either for the territory which she possessed in 1823, or for the part of Oregon which was assured by the treaty with Great Britain in 1846, or for the former LatinAmerican, Hawaiian, and Samoan territory which have been incorporated into the American Empire.

(2) The protectorates and semi-protectorates (Cuba, Haiti, Nicaragua, Santo Domingo, and Panama) are no longer possible subjects for European "colonization" or "political system", and therefore are not within the American Doctrine. All but Cuba came into their present situation, as we shall see in the next chapter, through a kind of reverse motion of the Monroe Doctrine. They are now protected substantially on the same basis 
as the Philippines and Porto Rico, - by the indivisible interest of the United States in territory which she virtually controls, and by her will to defend her flag wherever it floats.

(3) Of the groups of colonies, now that Spain is turned out of the West Indies, only the British are significant to the United States. They were all planted before 1823, except the extension of Belize and the Mosquito Coast, against which the United States violently protested as a violation of the Monroe Doctrine. Of late years there has been a frank acceptance in this country of the fact that the Canadians are loyal British subjects, who have no present desire for annexation to the United States, or for independence. Notwithstanding the recent suggestions of some Germans, which have already been discussed, Canada has never been considered in the field of the Monroe Doctrine, though a conquest of Canada would revive the issue of transfer of territory which has frequently been raised by American statesmen. Over the Danish islands the United States has. a sort of preëmption because treaties have twice been negotiated for their annexation.

This summary covers the whole of the two Americas, and their area may be re-analyzed as consisting of the following elements: (1) The continental territory of the United States, including Alaska ; all of which is absolutely outside the purview of the Monroe Doctrine; (2) the West India islands of Cuba, Porto Rico, Haiti, and the Danish group; in which the possession, protection, or probable future relation of the United States make a special interest which no European nation is likely to question; (3) the European colonies, French, British, and Dutch, against which at present there is no hostility from the United States; (4) the mainland countries of Nicaragua and Panama (enclosing the Canal Zone) in which the United States is now establishing a direct proprietary interest like that in the West Indies; (5) the Continental Latin-American countries, fragments of the old Spanish and Portuguese Empires, to which alone the Monroe Doctrine is at present applicable as a vital principle.

\section{SUGGESTED GËOGRAPHICAL LIMITATIONS}

The question has often been asked would it be possible, would it be advantageous, to set aside a part of South America as outside the limits of the Doctrine, and draw, say, the line 
of the Amazon River as a limit beyond which the interests of the United States are to be considered as no longer opposed to European interference or colonization. Historically there is no argument for this division; our government has never made such a distinction. If there is a different feeling toward Chile and the Argentine, it is not a willingness that they be a field of foreign conquest ; but assent to their ability to take care of themselves and so to prevent conquests. The only result of establishing such a line would be to make easier for Germany the opportunity of colonization somewhere in America. This suggested raising of the Monroe embargo, is, however, not strictly necessary for the end desired. As has been pointed out above, if enough Germans were so minded they might make a second Texas of Brazil, by emigration thither, till in force enough to control the government; the difficulty is that nobody feels any assurance that Germans in Brazil would wish to be colonists of the German Emperor, or could "deliver the goods." A German Brazil would be almost certainly an independent power, and as such would be entitled to the protection of the Monroe Doctrine.

Any geographical distinction between North and South America, or between regions to the north or south of the Amazon, is in conflict with the fundamental reason for the Monroe Doctrine, as stated by President Roosevelt in several messages, viz., that it is a doctrine of peace; and such it has normally been. The Monroe Doctrine prevents the creation of centers of friction and disturbance, and it saves America from the fate of Africa and Asia. To see those rich and prosperous regions, which might furnish homes for millions, left to sloth and misgovernment is painful. German or Italian rule would be more ship-shape. Still there is no certainty that open European control would improve the conditions of America. The occupation of Eretria by Italy and Cameroon by Germany, and of Cochin China by France, have not removed all sloth and misgovernment from those colonized areas. Nobody can foresee all the future greatness of the Amazon Valley and the La Plata Valley, which together contain by far the most valuable part of South America. They are already receiving large numbers of European colonists, from whom may eventually come a reorganization of the governments under which they live; but they ask for no withdrawal of the favoring side of the Monroe Doctrine. The experience of a hundred years shows that the 
Doctrine has at least kept the Americas out of the scramble of European diplomacy. Whatever the reasons for asserting it, those reasons apply to the most distant as well as the nearest sections of Latin America.

The observer cannot fail to notice that the United States has at last pushed far into the Caribbean Sea. Her only opponents have been the decaying Spanish power and the small defensive strength of the two negro republics. Fifty years ago the American people could not be brought to take an interest in securing coaling stations in the West Indies; now we are the leading Caribbean power. The French West India islands are of little value to the home country and very likely sometime will pass to the United States. The little Dutch islands off the coast of South America might go the same way. The one West Indian power that is likely to stick by its possessions is Great Britain, which has for nearly three centuries maintained naval stations in those seas. Jamaica and the smaller islands flank the world's waterway into the Panama Canal. At present, however, there is no rivalry between the United States and the Arglo-Saxon power, and Great Britain is not likely, so far as the eye can reach, to trouble the principal West Indian neighbor.

\section{EXPANSION OF THE UNITED STATES}

The usual point of view of American statesmen since the Mexican war has been that this country desires no territory belonging to a neighbor. Every case of annexation or protection has been urged on peculiar grounds, and has been recognized as an exception. Like many of his predecessors, President Roosevelt, in his message of 1901, disclaimed territorial ambition by the United States :

"The Monroe Doctrine is a declaration that there must be no territorial aggrandizement by any non-American power at the No Aggres- expense of any American power on American soil. sions by the United States. of any other." It is in no wise intended as hostile to any nation in the Old World. Still less is it intended to give cover to any aggression by one New World power at the expense

The reason for this principle has never been more clearly stated than by the same President in 1905 : 
" One of the most effective instruments for peace is the Monroe Doctrine, as it has been and is being gradually developed by this Nation and accepted by other nations. No other policy could have been as efficient in promoting peace in the Western Hemisphere and in giving to each nation thereon the chance to develop along its own

Responsibility of the United States. lines. If we had refused to apply the Doctrine to changing conditions it would now be completely outworn, it would not meet any of the needs of the present day, and indeed would probably by this time have sunk into complete oblivion. It is useful at home, and is meeting with recognition abroad because we have adapted our application of it to meet the growing and changing needs of the Hemisphere. When we announce a policy, such as the Monroe Doctrine, we thereby commit ourselves to the consequences of the policy, and those consequences from time to time alter. It is out of the question to claim a right and yet shirk the responsibility for its exercise."

The American spirit of expansion is one of the factors with which the world has to deal. The earlier extensions were as inevitable as the rising of the sun. The United States had the same reason for reaching the Gulf Coast and the mouth of the Mississippi that the Russians have for desiring control of the Bosporus and Dardanelles as an outlet. The extension to the Pacific Coast was a lofty policy which doubles the importance of the nation in modern conditions. Yet the annexations of 1898 were almost unaccountable, when one considers how regular were the warnings of writers and statesmen against assuming responsibility for alien folk. The world is beset by the notion that widely distributed territories with considerable population, in themselves make the home countries rich and happy. It is a fair inquiry whether India has not taken more gold out of the treasures of the English investor than was ever returned westward by the conqueror and official and trader. Men of affairs look on the Philippines as a gold brick. To undertake to govern Dominicans, Haitians, Cubans, Panamanians, and possibly Mexicans, is a still harder task for a country which finds it not easy to govern itself. It seems amazing that so much energy and money goes into the care of communities in which the members of the white races of the United States are not willing themselves to live. Still, expansion has been in the blood of the people ever since the Revolution and the passion has not yet run its course. 


\section{TRANSFERS OF AMERICAN TERRITORY}

At many points in the history of American diplomacy can be found discussions of the question whether any European colony or dependency in America can be transferred to another European country without infringing on the American Doctrine. A collateral question is whether an American power may cede any part of its territory voluntarily to a European power. A third question is whether a change of relation in a European home country, such as annexation by another country, would carry with it the colonies. A fourth question is whether these principles of transfer would apply with equal force to Japan or any other Asiatic power. On some of these issues the State Department has taken positive ground; on others we can only draw an inference; the unmistakable trend of public sentiment is against any kind of change except from one American power to another, and particularly from weak American powers to the United States.

(1) The transfer of colonies from one power to another was not mentioned in Monroe's declaration, but was opposed with vigor by Adams and Van Buren, and later by Fillmore and Pierce, when there seemed some possibility of the annexation of Cuba by England or France. The basis for this principle is simple : the hope of annexing Cuba was stated by John Quincy Adams, in 1825; while waiting a convenient opportunity it was safe to leave Cuba in the hands of a weak and declining power.

(2) The United States wants no new neighbors and is not willing to see present neighbors strengthened. Jamaica is the only large West Indian island not within the American sphére of influence that remains British; but no one could doubt that the United States would seriously object to any proposition to transfer it to Spain, France, or Germany. That issue may possibly be raised at the peace negotiations at the end of the European war. Great Britain has much desired to obtain the two islands of St. Pierre and Miquelon which were reserved in the treaty of 1763 as a fishing station and turned out to be chiefly a smugglers' depot; but they still remain French. Whether the United States would equally object to the sale of the Danish or Dutch islands to Germany, or to the conquest of the French islands, is a question still to be solved. The present 
tendency is strongly against any shifts in the West Indies; though in 1878, when the island of St. Bartholomew was transferred by Sweden to France, our State Department took no notice. The attitude of Germany, or rather of certain Germans toward a possible conquest of Canada and its transfer to Germany has been discussed in the chapter on the German Doctrine. Notwithstanding many controversies with Canada and about Canada, the United States has now established a kind of modus vivendi of peace and good understanding with Canada, which could not be expected to last if the Germans were to annex the country.

(3) Voluntary cessions of territory by American powers have been of little importance. Great Britain, France, and Spain have for centuries been possessed of islands for naval stations, and asked for nothing more. The only clear case of invoking the Monroe Doctrine against such a transfer was in the Magdalena Bay episode of 1912. The United States there objected not only to any claim of jurisdiction but also to the purchase of land by a Japanese company which might be the entering wedge for occupation. The indirect influence of the Monroe Doctrine in this respect has doubtless been large, for there are irresponsible and temporary despots who would be glad to make a dishonest penny by selling islands or even mainland ports to the highest bidder. The prevention of the establishment of such points of friction is one of the main services of the American Doctrine, and is quite as much to the interest of other American powers as to that of the United States.

(4) The question of the effect on colonial possessions of the transfer of the home country has not yet come to the front, but is likely to become serious. If Holland were to be absorbed by Germany, or Denmark by Russia or England, would their West Indian colonies go with them? The same question is raised on a larger scale with respect to Belgian Congo; and here there is no doubt that if Germany has the physical power and disposition to annex Belgium, it will take all the appurtenances.

\section{CONQUESTS OF TERRITORY}

Notwithstanding the stern prohibition of Monroe, several efforts have been made by European powers to plant their flags permanently on American soil; in each case the American 
power concerned has violently protested, and in several instances appeal has been made to the United States:

(1) Ever since the first settlement of Belize by the English logwood cutters in 1638 Great Britain has made efforts to enlarge its boundaries, first at the expense of the Spanish kingdom of New Spain, and later of the Latin-American States of Honduras and Nicaragua. In 1852 the Bay islands were added to the colony and a strong effort was made to push the boundaries inland. The United States flatly expressed her disapprobation of this action and eventually it was given up.

(2) Buenos Ayres, in 1831, insisted that the English were occupying their territory in the Falkland Islands, but the United States sided with England in the controversy and pooh-poohed at the suggestion that the Monroe Doctrine was involved.

(3) A similar long and obstinate insistence on a British protectorate of the Mosquito Coast was based upon the ancient but shadowy theory that the Mosquito Indians had a responsible king and that he was the dependent of the British government. Great Britain nominally gave way on this point in 1860 and actually yielded in 1894 .

(4) Tigre Island was held for a short time by the British in 1849 which was considered a particular iniquity just then because the United States wanted it for herself.

(5) Boundary controversies with European powers can happen only on the rim of the three Guianas. Brazil rather easily adjusted her difficulties with France and England. The trouble between Venezuela and Great Britain in 1895 has been sufficiently described.

(6) France avoided the specific issue of conquest in Mexico by setting up a nominal Mexican Empire. The American government penetrated that fiction on the ground repeatedly stated by Seward that the Mexicans had not voluntarily accepted either the French occupation or the sham Empire.

\section{CHANGES IN EUROPEAN CONDITIONS}

The amazing changes in the governmental and international conditions of America are hardly greater than those in our relations with Europe. When Secretary Olney reiterated that the United States had no share in European complications, he did not expect that the United States was going to press an active 
policy in Turkey, or to take up the cause of the Jews in Russia and Rumania. The political system of Monroe's time has broken down. Not only has the concert of European powers disappeared, but Western Europe has become democratic, except in the terrors of war, when great nations accept unhesitatingly the decisions of a small group of statesmen who are practically designated by themselves. The contrast between American republics and European monarchies has ceased. Switzerland is hardly more democratic than Denmark, Sweden, and Norway. Belgium, Holland, Austro-Hungary, Italy, Germany, even Russia, accepted democratic forms. France has been for forty-four years a republic. England in ordinary times is more responsive to public sentiment than the United States. North and South Americans alike realize that they have something to learn from the practice of European governments. No one can yet measure the effect upon democratic sentiment the world over of the present war. British and French and Italian democracy are all on trial; for the first necessity of any type of government is that it should endure; and no nation can endure which is unable to defend itself.

The European war has also sharpened the minds of the American public to what is going on over there. The man on the street is glib on the motives of Russia and Rumania and Germany and Holland and all the rest. The farmer shipping his wheat is alert to know what the position of Germany or Great Britain is on food-stuffs as contraband. The United States had begun to feel a responsibility for bad and oppressive government, not only in America, but in Europe and Asia. Mr. Bryan came home from India and freely denounced what he considered the exploitation of that country by Great Britain. An American administrator, Shuster, in 1911 was placed in charge of the finances of Persia. Americans have been excited over Armenian massacres and Balkan atrocities and the "pogroms" against Jews in Russia. A proof of a rising tide of interest in distant affairs is the majority found in Congress for putting an end to the Russian commercial treaty of 1832 on the ground that the Russian government discriminated against American citizens of Jewish origin. The intense national interest in the fate of Belgium had in the minds of some men of weight reached the point where they demanded that the United States go to war with the conqueror of Belgium as a protest. 
Commercial relations with Europe are also much more intimate and important than they were in 1823 ; a single ocean steamship in a year will carry a fifteenth as much as the whole foreign commerce of the United States in 1823. Within the borders of the United States live eight million persons born in European countries; a hundred thousand Americans annually visit the Eastern Hemisphere. Missionaries and commercial travellers, the two advance agents of civilization, are found in every European country, and American oil, food products, and manufactures spread throughout the world. When the American tariff draws its cabalistic circle of exclusion, the tin-miner of Cornwall, the button-maker of Vienna, the potter of Limoges, and the weaver of Saxony become aware of the weight of our government. Let any one examine the useful government publication known as Foreign Relations during the last twenty years, and one will be amazed at the amount and multifariousness of present American interests in European countries.

The fiction of the Two Spheres may therefore be dismissed, for it is neither a social fact nor an international need. In times of peace, and still more in times of war, the action of the lawmakers of Great Britain and Germany and other European countries wakes people up, because it may mean a restriction or an enlargement of American trade.

The most striking change in the conditions of nations is the building up of large units. Consolidation applies not simply to banks and factories and railroads, but to world powers. Down to the French Revolution there were about a hundred so-called independent states in Germany; now they are reduced to the twenty-seven members of the German Empire, several of which are controlled by powerful neighbors, and all of which accept the leadership of Prussia in time of war. The possible great world powers are coming down in number. A hundred years ago Turkey was one of the great states of Europe. Now it is a dependent ally of Germany. The prophet who looks forward another century will see three great European powers, - Great Britain, Germany, and Russia ; one great Asiatic power, China; and one great American power, - the United States. If those five powers will develop a set of international principles and live by them in peace, they will lay down the law to the rest of the world. France, Italy, the Balkan States, Japan, have not. sufficient territory and population to play a great part in the 
world's history permanently. Agreements and disagreements between those five powers will make up the greater part of the history of the world during the next hundred years. The United States could not stand neutral in a western geographical sphere, if it would; and the ambition of its people is that it should take its part in the big world.

\section{CHANGES IN LATIN AMERICA}

In the chapter on the Latin-American Doctrine attention has been called to the physical and social changes to the south of us. Many political changes have occurred. The long-continued Brazilian monarchy and the brief Mexican monarchy have disappeared, and all America south of Canada is covered with nominal republics. Since 1823 the external interests of Europe have changed their direction from America to Eastern Asia, Africa, and the Near East. No country, except Great Britain, has now any significant colonies in America; therefore there is little difficulty in accepting the Latin-American states as members of the world system. Treaties have been made with them frequently, and they have been admitted to the second Hague Conference and Tribunal, though one of the main difficulties in the resulting arrangements has been the question whether in a permanent arbitral court each nation should have an equal voice. The fear of democracy, whatever it may have been in 1823, is no longer a motive in Europe. Latin America is not democratic; and if it were, has little influence in European affairs; while the bugaboo of foreign interference with republican government in the United States has long since passed away. In commerce and business, Europe has accepted the LatinAmerican powers as substantial and independent; immense investments of foreign capital have been made; and Europe shows little disposition to interfere with what may be considered the permanent status of these powers.

On the other hand, European nations have for a century had a continuous series of difficulties with Latin-American states over claims; a difficulty heightened because the authorities of those states commit arbitrary and predatory acts against both nationals and foreigners; but the foreigner has his own government behind him and is therefore in a better situation than the national. Many of the claims are bad or exaggerated; many 
others are perfectly just, and yet are neglected from decade to decade. Yet, except for the French invasion of Mexico, there have been few cases of the use of force for the collection of money ; and the Drago Doctrine, accepted in spirit by President Roosevelt, would automatically take away the necessity of applying force and of perhaps encountering the American Doctrine in such cases.

Without doubt the American Doctrine, as it is commonly construed, is distasteful to the great European powers. They deny that it is international law - and how can it be international law when denied by such a group of states? They feel that the argument of the "Two Spheres" has ceased to have force since the United States has taken an interest in Asia; they have many causes of friction and collision with Latin America and feel that the United States prevents them from settling such troubles in their own way. What they recognize in the American Doctrine is simply the insistence of the United States that she shall be heeded.

So far as revolutions, civil war, and anarchy are concerned the only peaceful continental lands between the United States on the north, and the A B C powers on the South are the Republic of Panama, and (for the time) the Republic of Nicaragua, both under the direct control of the United States. Civil wars are fewer because the A B C powers have adjusted their boundaries with each other and with their neighbors. The Guiana boundaries are now about completed, though as late as 1895 Brazil and England almost came into collision over the attempts of the British on the island of Trinidad, which was claimed by Brazil ; Brazil's claim was eventually acknowledged. The same year the imprisonment of a vice-consul in Nicaragua gave rise to a dispute with Great Britain, in the course of which Nicaragua offered to transfer certain islands. Since that time the only serious issue between European and Latin-American powers has been the Venezuelan question of 1902. 


\title{
Chapter XX
}

\section{DOCTRINE OF AMERICAN PROTECTORATES}

\author{
RESPONSIBILITY OF THE UNITED STATES TO EUROPE
}

The crisis of the modern American Doctrine, which is erroneously called the Monroe Doctrine, was reached in 1902 when the United States laid down the terms on which England, Germany, and Italy might approach the coast of Venezuela with hostile ships of war. The most ordinary principle of selfinterest argued against letting foreign navies get accustomed to the sea road between Europe and America. Hence those precautions and limitations and agreements that no forces should be landed and no territory should be occupied; they were intended not so much for the welfare of Venezuela as for the peace of mind of the United States. Pursuing this policy of limiting the responsibility of Latin America, the delegates of this country pushed the Drago Doctrine on the Hague Convention of 1907. It was the administration at Washington that felt apprehensive over the appearance of hostile squadrons in American waters. It was the Federal government that thrust itself between the European creditor and the American debtor. In the case of Venezuela, the foreign powers galvanized the delinquent state into agreeing to an arbitration on the pending claims. Before the tribunal in 1904 the three powers secured the further principle that other debtor nations could not come in and take advantage of the settlement, to obtain which they had spent no money on a blockading fleet. This was a suggestion that any European power whose citizens could not collect their debts from a Latin-American government or its people, had only to send a warship, make a bluster, and they would receive attention and payments on account while the other creditors cooled their heels outside, and the United States looked on. One experience of an invasion with a promise not 
really to invade was enough to convince the United States that even the most innocent and peaceful military intervention was awkward and undesirable.

President Roosevelt saw that point and also perceived the only rational way of preventing armed interventions, which was to put a pressure on naughty American states to be good and cease making trouble. If they would not be good for the United States, then they were to be made to behave. This is the famous Doctrine of the Big Stick which has already been discussed. It involves the idea that all the Latin-American States except four or five are in a sort of second class, and not entitled to the dignity and privileges of sovereign states; hence they must accept the counsels, reproofs, and discipline tendered them from time to time by the United States. Upon this question President Roosevelt dwelt in his message of 1904.

"If a nation shows that it knows how to act with reasonable efficiency and decency in social and political matters, if it keeps

Interna-

tional

Police

Power. order and pays its obligations, it need fear no interference from the United States. Chronic wrongdoing, or an impotence which results in a general loosening of the ties of civilized society, may in America, as elsewhere, ultimately require intervention by some civilized nation, and in the Western Hemisphere the adherence of the United States to the Monroe Doctrine may force the United States, however reluctantly, in flagrant cases of such wrong-doing or impotence, to the exercise of an international police power."

This is clearly a way out of a serious quandary. The United States must either "fish or cut bait." To hold off the avenger because he was hurting the American Doctrine, and thereby endangering the United States, would have been futile, unless the United States somehow compelled the offending state to be a real state.

\section{RESPONSIBILITY TO LATIN AMERICA}

On any theory, the United States has a natural political influence over her neighbors which no foreign country exercises. We have been the teachers of sister republics, most of whom have quickly forgotten their lesson. The United States is so near several of these countries that their disturbances stop trade and trouble the border. The reason most often put forth 
for the protectorate of Cuba, the conquest of Porto Rico, and the present great influence in the island of Haiti is that the local civil wars annoy the United States. The troubles of Mexico have for four years reacted on the frontier of Texas, leading to lawlessness and a desire to take revenge by crossing the border, and punishing Mexican bandits.

The best Latin-American writers on the subject, such as Alvarez, frankly admit the service which the United States has rendered by keeping alive the sense of "America for Americans", and by her example on matters of consequence to both North and South America, such as the treatment of immigrants, and the disposal of public funds. The United States has in a few cases taken a hand in the framing of a new Latin-American government. Influence from Washington has repeatedly urged the Central American States to unite; and has taken a decided stand on the government of Mexico.

Perhaps more good could be done by trying to exert a little influence against the despots. Our usual principle is to recognize the de facto governments, meaning the faction that for the moment has control of the capital, the army, and the treasury. The assumed reason for this course is that the United States will accept whatever government the people of a country choose for themselves. Very rarely has the State Department taken the ground which it took toward the Huerta Administration of Mexico; namely, that it would not recognize as head of the State a man who could not show the backing of the votes or the goodwill of his countrymen, but who was believed to have come to power by murdering his predecessor. Seward wrote to our minister in Chile in 1866 that his government will -

"Maintain and insist, with all the decision and energy which is compatible with our existing neutrality, that the republican system which is accepted by the people in any one of those [South American] states shall not be wantonly assailed, and that it shall not be subverted as an end of a lawful war by European powers."

\section{DOCTRINE OF INFERIOR NATIONS}

The obvious way of preventing trouble is to try to keep the governments of weaker powers in a reasonable and temperate frame of mind. The three A B C powers recognize the duty 
and advantage of order and honesty. Several other powers have neither the spirit nor the means to satisfy their debtors. The little state of Ecuador, for instance, has a nominal outstanding debt of $\$ 20,000,000$, which, so far as the financial world can see, will never be paid. If persuasion and appeals to national honor fail, the next step is to use compulsion. Peaceful compulsion is a difficult matter, but compulsion by war between equal nations, the world recognizes. There is no such thing as military coercion in times of peace. Ever since the days of the Greeks and the Persians, there has been a world-wide prejudice against pushing war upon a feeble folk; and when, in 1914, Austria with $52,000,000$ people, proposed to discipline Servia with $4,500,000$, three great nations stepped out as champions against this attempt on the sovereignty of a little state.

A solution of these difficulties can be found if it be admitted that the forty-eight or so nations of the earth are not equal, but are roughly divided into real nations and inferior nations. Apply that doctrine to America. The world thinks such states as Venezuela, Paraguay, and Salvador weak and imperfect states, physically unable to defend themselves against any strong enemy, and in no position to take the responsibilities of sovereign nations. The world tends to hold the same opinion without discrimination about all the other Latin-American states. In that general belief the United States shares.

The ideal of complete sovereignty to be enjoyed by every nation on earth has its conveniences: it is a bulwark to little states to which the world owes much; and it furnishes a set of general definite principles which operate in the big really sovereign states. Nevertheless, all political communities are not equal. International law recognizes dependencies which are partial states, subject, like Panama and Cuba, to the will of another state. International law objects to recognizing the truth that the world is made up of two different types of nations, the fit and the unfit; the organized and the boneless, the trustworthy and the undisciplined. Japan and Siam are docketed as equal Asiatic kingdoms. Persia, Montenegro, and Paraguay send and receive ambassadors, make treaties, and solemnly act as though they were the international equals of China and Italy and the United States. 


\section{INFERIORITY APPLIED TO LATIN AMERICA}

Roosevelt had this principle in mind when he secured the Panama Canal Zone. To his mind such a state as Colombia was incapable of constructing a canal out of its own means, had not credit to borrow the necessary money, and could not protect and defend the canal when finished. Hence it had no right to hold the only strip available for an Isthmian Canal against a nation which could bring to bear the necessary energy and capital and military power.

The same thing applies in other relations. The United States is inclined to think that the A B C powers can take care of themselves and can keep out of the troubles which lead to the eternal bickerings over claims; but at present we look on Mexico as a wild man, and on the Central American powers as incorrigible children. The Calvo Doctrine falls to the ground at once unless you admit its foundation principle, which Calvo has expressed as follows:

" America, as well as Europe, is to-day peopled by free and independent powers, whose existence as sovereigns is entitled to the same respect, and whose internal public law is not subject to any kind of control by foreign nations whoever they may be."

"Whoever they may be" refers to the United States as much as to Europe. Calvo's country, the Argentine, and four or five others, do not hesitate to draw distinctions between themselves and the small countries; but if they once admit that Ecuador can be controlled from without because inferior to the Argentine, they also admit that the Argentine may rightfully be controlled by Germany because inferior to that power. Since foreign interventions, actual and threatened, almost always fall on the weak states, the United States finds it difficult to explain just how those small states are so completely independent that foreign nations must not touch them, and at the same time are so far from independent that the United States will not trust them. Edgington, an ingenious writer on the Monroe Doctrine, has found a solution to his mind in a suggestion that both the rights and laws of such states should be ignored.

"Our proposition is that the public policy of the United States, with reference to its citizens who are temporarily domiciled in 
foreign countries, and who make contracts there, controls over the public policy or status of foreign nations, who have statutes and a public policy which is contrary to our own."

The same writer seriously proposes that when a LatinAmerican state misbehaves, its neighbors shall put it into a "receivership," until it gives up its naughtiness.

Some distinctions must be made, such as President Roosevelt made in his message of 1905 :

" There are certain republics to the south of us which have already reached such a point of stability, order, and prosperity that they Distinction. themselves, though as yet hardly consciously, are among the guarantors of this Doctrine. . . . If all the republics to the south of us will only grow as those to which I allude have already grown, all need for us to be the especial champions of the Doctrine will disappear, for no stable and growing American Republic wishes to see some great nonAmerican military power acquire territory in its neighborhood."

\section{LIBERTIES WITH LATIN-AMERICAN SOVEREIGNTY}

One unmistakable mark of the fact that the United States has not recognized our neighbors as equals is the practice of asylum for so-called political criminals - usually revolutionary leaders who have either failed to upset the reigning despot or are no longer able to maintain themselves as heads of the state. Some of these gentry are professionals, who have served as chiefs of revolutionary armies in several countries, and who play the game within and without the land of which they are citizens. The people of the United States look upon these men, who are often ugly ruffians, as not morally responsible for their efforts to overthrow the government and shoot the dictator; and receive an escaped conspirator as a curiosity.

A striking example of harboring of persons held by their own governments to be criminals was the Barrundia case of 1890 . Barrundia, a fugitive revolutionist from Guatemala, was a passenger on an American merchant steamer which touched at a Guatemalan port. 'The deck of a merchant vessel is in all civilized countries simply a part of the territory in which it lies. The local authorities, therefore, came off to capture Barrundia : he resisted, and was shot and killed. 
An American vessel of war was lying near by, and its deck was, under international law, a bit of American floating territory; but Commander Reiter, on the advice of the American Minister, Mizner, declined to interfere. Had the affair happened in Marseilles and had he interfered, our Government would have apologized or there would have been war. Had an English cruiser interfered to prevent the capture of an American on board an English merchant vessel in New York Harbor, the commander of any fort might have been justified in turning his guns on the man-of-war. The officer of the American ship, who had declined to exercise authority within the territory of a friendly power, received the severest naval penalty short of cashiering, and the minister was dismissed. The principle of the Barrundia case is simply that American ships of war are not bound by ordinary territorial rights in weak American states.

This case became a precedent for the harboring of partisans of Balmaceda, the defeated and discomfited ex-President of the Republic of Chile in 1891. During the civil war of that year several of the Congressionalist party took refuge in the American Legation, which sheltered them from the Balmacedists. The privilege depends on a principle of international law applied in the less civilized parts of the world. The official residence of the minister of one country in the country to which he is accredited is always considered a bit of his home territory; neither he nor his servants may there be molested, nor may the officers of the law enter it. In countries like the dependencies of Turkey, Japan, and China, Spain, and the Latin-American States, ordinary fugitives from justice are rarely sheltered in the embassies. In disturbed and revolutionary countries, especially Latin-American, the sanctity of the ambassador's house is by tacit consent extended to the case of political refugees. Governments rise and fall rapidly, and the dictator of to-day may be the outlaw of to-morrow. The privilege is not supposed to be perpetual ; the fugitive is protected till he can escape, or till the government relents, or till his party comes in again. In this manner Minister Egan received two partisans of the Congressionalist party; when the crash came, he received Señora Balmaceda and about sixty other persons. Other legations did the same: Balmaceda himself was for a time sheltered by the Argentine Minister. 
Egan advanced another doctrine, which could not fail to be offensive; he claimed as a part of the right of asylum the safe departure of the refugees out of the country. In a dispatch of October 22, 1891, Mr. Egan said to the Chilean Government:

"There can not, therefore, be cause for surprise on the part of your excellency if the Government of the United States should interpret as an act of but slight courtesy and consideration that the Chilean Government, having the power in its hands to make this friendly manifestation, should not wish to do so in accordance with the respect due to the invariable practice and international policy of Chile."

Eventually, rather than provoke a quarrel on the subject, the Chilean Government permitted some of the refugees to leave the country.

The motive for this protection was the belief that the restored Congressional government meant to avenge itself on prisoners. It was humane - but it violated a principle which could never be applied in the United States. It was a clear assertion that Chile - and if Chile, then any other LatinAmerican power - was on a lower scale of civilization and government than other American powers, because she threatened her neighbors. When Secretary Frelinghuysen was informed in 1882 that Uruguay might find it necessary to cede her territory to the Empire of Brazil, in satisfaction of a debt, he replied with the following mild suggestion:

"In reply, I have to state that it is to be hoped that the con-

No Trans

fers by

Republics to

Monarchies. tingency you fear may not arise. While the United States wish not to encourage any nation in making default in the payment of debts, this government would be reluctant to see a republic which has a large bonded debt so hand over its territory to a monarchy that the government of the same would cease to be republican."

On this question of the transfer of territory the United States had not the same scruples, when Colombia was suddenly deprived of the State of Panama in 1903. Notwithstanding the theory of the United States that this was a legitimate revolution, the Colombians looked upon it as a direct intervention to prevent their putting down the revolution, followed by an unjust occupation of the Canal Zone, which they consider still 
to be Colombian territory. For a time Colombia refused to keep up diplomatic relations with the United States, and up to 1915 never recognized the independence of Panama.

\section{INTERVENTIONS BY THE UNITED STATES}

The action of the United States in her own quarrels with her neighbors has usually been of writing paper mixed with possible blood. We have made many strong diplomatic protests and have sent few armed forces. The principal instances of sending troops against other American powers, begin with the forcible occupation of West Florida in 1810. In 1818 General Jackson invaded East Florida and was never censured by his government. The ship Lexington, sent by President Jackson, uprooted what claimed to be a colony of Buenos Ayres in the Falkland Islands in 1831. In 1846 regular troops of the United States occupied the disputed belt along the Rio Grande and then pushed into undoubted Mexican territory, while other forces seized New Mexico and California. Greytown within the bounds of Nicaragua was bombarded by the guns of a United States ship in 1854. In 1859 an expedition was sent to Paraguay. Chile was threatened with war by Harrison in 1892. The Brazilian navy was warned to behave in 1893. Mexico has been warned at various times, especially in 1914, when there was a battle at Vera Cruz. Except in the Mexican War, however, the only dispatch of organized armies and fleets by the United States in America was in the Spanish War of 1898.

\section{PROTECTION OF LATIN-AMERICAN STATES}

Whatever the warp of the Monroe Doctrine may be, its woof is that weak states, which otherwise cannot defend themselves, should be defended by the United States. It is remarkable how few instances can be found in which the United States has gone beyond paper warnings in their behalf. Not a soldier was raised or a ship built with a view to making good the original Monroe Doctrine. The Administration did nothing but write dispatches against European wars upon the former Spanish colonies. The United States protested several times at aggressions of the British in Nicaragua, and even landed marines, 
but the Mexicans had to wait from 1861 to 1867 before their neighbor gave the decisive good advice to the French to leave Mexico. The government protested, but did not send a gunboat, when, in 1861, the Spaniards tried to annex Santo Domingo. In the two Venezuela episodes of 1895 and 1902, great nations held back from the use of force, but held back because of the words of the United States and not because of her ready rifles. Marines were landed five or six times to protect the Panama railroad, but always in accordance with the treaty of 1846 with Colombia, which allowed such action, and in none of these cases was a foreign enemy feared. Up to the present time the United States has made no sacrifices of men or money in defense of other American states, unless the landings in Cuba in 1898 and 1906 can be held to be a protection to the Cubans against enemies from the outside.

One wonders why Europe has paid so much attention to the Monroe Doctrine, Polk Doctrine, Seward Doctrine, Evarts Doctrine, Olney Doctrine and Roosevelt Doctrine. What would have happened if Spain had transferred Cuba to France in the fifties? Would the United States have gone to war if Great Britain had paid no attention to Cleveland's protest about the Venezuela boundary? Would the navy be despatched to the La Plata if the Germans seized Montevideo? - The real strength of the American Doctrine is that it is the undoubted will of a nation of great potential strength which is set in the midst of the Americas. The American Doctrine has behind it the defensive force of the scores of millions of still unborn citizens of the United States. As for actual rifles, submarines, and army corps, they are also still in embryo.

\section{PROTECTORATE OF CUBA}

In the large, the United States looks upon all the LatinAmerican States as protectorates; that is, as nations which under no circumstances are to be allowed to be annexed or brought into foreign spheres of influence, or made satellites by foreign nations. Diplomats are familiar with the practice of Europe in treating weak states as protectorates. Little San Marino, Monaco, and Andorra, all nominally independent governments, are simply political playthings for the Italians, French, and Spaniards. Portugal is under British influence; 
Turkey is at present a dependency of Germany. Egypt has for twenty years been an English subordinate state. Why may not the same principles be applied to specific parts of America by the United States?

The first experiment in that direction was made in 1898, when Cuba was conquered from the Spaniards. Carrying out the promise of the Teller Resolution, passed when war was declared, the United States honorably aided the Cubans to a republican government of their own. In 1902 while they were forming a constitution, Congress adopted the so-called Platt Amendment which was drafted by the President and Cabinet: the new Republic was required to insert into its constitution the following appendix :-

"The Government of Cuba shall never enter into any treaty or other compact with any foreign power or powers which will impair or tend to impair the independence of Cuba, nor in any way authorize or permit any foreign power or powers to obtain by colonization or for naval or military purposes, or otherwise, lodgement

No Foreign Colonization or Dependencies. or control over any portion of said island."

" That said Government shall not assume or contract any public debt to pay the interest upon which, and to make reasonable sinking-fund provision for the ultimate discharge of Limited which the ordinary revenues of the Island of Cuba, Public Debt. after defraying the current expenses of the Government, shall be inadequate.

"That the Government of Cuba consents that the United States may exercise the right to intervene for the preservation of Cuban independence, the maintenance of a government adequate for the protection of life, property, and individual liberty, and for discharging the obligations with respect to Cuba imposed by the

Intervention by the United Treaty of Paris on the United States. . . .

"To enable the United States to maintain the independence of Cuba, and to protect the people thereof, as well as for its own defence, the Cuban Government will sell or lease to Coaling the United States the lands necessary for coaling or Stations. naval stations, at certain specified points, to be agreed upon."

The practical reason for this assumption of authority over Cuba, so far as it concerns European powers, is briefly stated in the messages of President Roosevelt of 1902 and 1903. 
"Cuba lies at our doors, and whatever affects her for good or for ill affects us also. So much have our people felt this that in Cuba in our the Platt amendment we definitely took the ground Political System that Cuba must hereafter have closer political relations with us than with any other power. Thus in a sense Cuba has become a part of our international political system."

"When the acceptance of the Platt amendment was required from Cuba by the action of the Congress of the United States, this GovCuba as a ernment thereby definitely committed itself to the Protectorate policy of treating Cuba as occupying a unique position as regards this country. It was provided that when the island became a free and independent republic she should stand in such close relations with us as in certain respects to come within our system of international policy; and it necessarily followed that she must also to a certain degree become included within the lines of our economic policy. Situated as Cuba is, it would not be possible for this country to permit the strategic abuse of the island by any foreign military power."

It is sound reasoning that the United States, after going to war with Spain in order to bring peace and order to Cuba, should continue to take the responsibility for Cuba's not becoming a new disturbing element. The right of intervention covered by the Platt Amendment was used in 1906 when the republic fell into disorder; and a military force was sent down which occupied the island for more than two years. Not till 1909 was the force withdrawn and Cuba returned to the Cubans.

\section{PROTECTORATE OF PANAMA (1903-1914)}

The next region which has virtually come within the territory of the American Empire, though nominally an independent State, is the Republic of Panama. That little State was born in the midst of the remarkable revolution of 1903, and within sixty hours was recognized by the United States as independent. A government was at once founded whose first significant step was to make a treaty with the United States which virtually ceded the Canal Zone. From that time to the present day, Panama stands in the list of independent States in the Statesman's Yearbook. Is it really independent?

The Canal Zone is practically a strip of United States territory, ten miles wide, which runs through the middle of the Republic of Panama with its thirty-two thousand square miles 
and four hundred thousand people. When the United States undertook to build the Canal and to allow all nations to use it, she practically guaranteed to the world that there should be no further trouble in Panama, which had for many years been a very disturbed part of the United States of Colombia. The power that is spending $\$ 400,000,000$ on a great artificial water channel, built by the United States, controlled by the United States, and fortified by the United States, feels that it has a right to make sure that the so-called State of Panama does not interfere with the safety of the works and the security of transit. Hence, at intervals ever since 1903, the United States officials have from time to time made it clear that they prefer to see this or that man elected to office by his fellow Panamanians. No serious dispute can possibly arise between Panama and other nations, because Panama must, in the nature of things, always follow the advice of the President of the United States on any question which might make trouble with foreign countries. To refuse to follow that advice would be considered an offense against the dignity and welfare of a nation of a hundred millions.

\section{PROTECTORATE OF SANTO DOMINGO (1905-1915)}

From the time of the intervention in Venezuela in 1902, President Roosevelt felt the responsibility of his administration for keeping order in countries which European nations were not allowed to invade or seize. No power more needed relief from wrong-doing than Santo Domingo, in which, between 1899 and 1904, there were five successive despotisms, each trampling on its predecessor. A debt of nominally thirtytwo millions of dollars burdened the republic, which seemed bankrupt, although the importations were considerable and the customs duties were comparatively large. President Roosevelt, therefore, March 31, 1905, entered into an agreement with the Dominican Republic as follows:

" To attempt the adjustment of all the obligations of the Dominican Government, foreign as well as domestic ; the adjustment of the payment and of the conditions of amortization ; the consideration of conflicting and unreasonable claims, and the determination of the validity and amount of all pending claims." 
Then the United States was to take control of the customs houses, put in employees and receive the duties, paying 45 per cent to the Dominican Republic and 55 per cent (less salaries) to a fund for the interest on the debt. In addition the United States gave assurances that -

"The Government of the United States, at the request of the Dominican Republic, shall grant the latter such other assistance as the former may deem proper to restore the credit, preserve the order, increase the efficiency of the civil administration, and advance the material progress and welfare of the Dominican Republic."

The Senate was not much pleased by the action of the Presi. dent in committing the country to such an "agreement", which would for the time have as much force as a treaty requiring their ratification. A regular treaty was then brought forward, but no action was taken until 1907, when a slightly amended version was ratified. By that time, over two million dollars had been saved and set apart for the creditors. Through the influence of our government the debts and claims were funded at about fifteen millions.

Since 1905 American officials have remained in charge of the custom house. In 1915 the public took uncomfortable account of the fact that Secretary Bryan was urging the head of the custom house service to look out for places for "good democrats," which seemed to show a conception that the officials of the negro republic, out of whose funds these functionaries are paid, were to be chosen with more reference to the interest of a political party in the United States than the interests of the Dominicans.

\section{INTERVENTION IN CENTRAL AMERICA (1906-1915)}

In 1906 a revolution broke out in Guatemala. Salvador and Honduras were accused of aiding the rebels, and the regular Guatemalan government made war on those two neighbors. President Roosevelt and President Diaz joined in instructing their ministers to Guatemala to soothe the rival powers and a conference was held on board the American ship of war Marblehead. This led to a general treaty of peace of the five powers, at Washington, which was a first-class example of the good that the United States could do by friendly suggestion. 
Unfortunately, the very next year President Zelaya of Nicaragua prepared to attack Honduras, and United States marines were landed to keep order in the port of Ceiba. Commander Fullam of the United States ship Marietta served a notice which seemed to commit the United States to a new kind of intervention :

"It must be perfectly plain that foreign interests could not possibly be secure if bombardments were permitted. On the contrary, such interests would be subjected to the danger of complete destruction in every case. If bombard- bardments. ments of coast towns are to be resorted to during the frequent wars and revolutions in Central American States, the mercantile interests of all foreigners will be absolutely insecure in the future.

"... A ship of war ordered here to protect American interests could not be excused for subjecting these same interests to inevitable ruin by permitting the destruction of these towns by fire and bombardment.

"Fully three-fourths of the valuable mercantile and business houses in these coast towns are owned by foreigners."

Under the treaties drawn in the Washington Conference of 1907, the United States felt that she had a special right in Central America as a consulting and advising party. In 1910, two Americans, Cannon and Groce, were shot by Zelaya's order, on the charge that they had aided revolutionists to destroy a Nicaraguan ship. Secretary Knox protested, and refused to keep up diplomatic relations with Zelaya's government, and there was wild talk of bringing him to the United States and executing him here. The case was not so clear as it looked, for the two Americans had lived for years in Central America, and were said to hold commissions in the revolutionary army. On the other hand, Zelaya was in the habit of speaking with contempt of the United States, and Secretary Knox retorted with a tart statement of the interests of the United States in Central America.

\section{PROTECTORATE OF NICARAGUA}

Our government then took decidedly the side of the Nicaraguan revolutionists; and in 1911 Knox made a treaty by which Nicaragua (that is, the revolutionary party), was to be aided to arrange a loan for the funding of all the public debt, and the 
United States was to see to it that Nicaragua carried out her promises. The Senate refused to ratify the treaty; and, almost exactly as in the case of Santo Domingo, President Taft made an agreement without the aid of the Senate, and sent down a representative to take charge of the Nicaraguan custom house and to pay the proceeds into a fund for the benefit of the creditors. Such a representative, who is not really a federal official, and still less a Nicaraguan, is still in virtual control of the custom house in 1915.

By this arrangement the United States practically made herself responsible for peace and order in Nicaragua, in order that certain New York bankers who had risked a certain amount of cash should be protected in their investments. This was a more serious responsibility than in Santo Domingo, where the United States government had no rival governments to confront. The Nicaraguans had the ingratitude and bad taste to raise another revolution in 1912 , which added about $\$ 1,000,000$ to the official debt. 'The new government, headed by Mena, had already pledged all its taxes and even a "government reserve of 300,000 litres of brandy" and now handed over control of the internal revenue and shares in a government railroad, to the bankers. Practically the whole financial system of the Nicaraguan government was thus pledged to foreigners, who were backed up by the United States government.

To this desperate, bankrupt, and war-harassed little country Secretary Bryan in 1913 offered a new treaty "for the preservation of Nicaraguan independence," by which the United States was to pay $\$ 3,000,000$ in cash to Nicaragua - a suggestion like that made to Mexico in 1861 - and in return our government was to receive the right to build a canal through Nicaragua (which was clearly of very little value), certain islands in the Caribbean Sea and a naval base on the Pacific side. As a kind of offset, a series of limitations corresponding to the Platt Amendment to Cuba was to be accepted by Nicaragua, including the statement that "the United States have the right to intervene for the preservation of Nicaraguan independence."

\section{DOLLAR DIPLOMACY}

In spite of strong pressure by President Wilson and Secretary Bryan, this treaty was not ratified by the Senate of the United 
States. One objection was that the United States was simply giving its support to American capitalists in funding the debt at a figure far above the sums which anybody in Nicaragua had received; and that they were taking possession of the railroad which was almost the only asset of the Republic that was left. During this long period of storm and stress a small body of American marines was posted at. Managua, the capital of Nicaragua, nominally in order to defend the customs officials, who had no international right to be there. Through this little military force, through the influence of the banks, and through specific directions from the State Department, our government took direct responsibility for supporting or refusing to support the aspirants for the Nicaraguan presidency. Independence was for the time at an end. Nicaragua was a protectorate of the United States, so far as the Administration could bring it about. Nobody except the State Department seems to feel any enthusiasm for this condition of things.

A similar influence has been brought to bear upon Honduras with a treaty negotiated for a scaling of the debt, but nothing came of it.

The policy of subsidizing a Latin-American state so that it may pay its debts to American financiers, has been much criticized. A similar policy was invoked for settling the controversy over the Isthmus. Secretary Root in 1909 proposed to Colombia to accept $\$ 2,500,000$, to be taken out of the annual payments to Panama for ten years. Secretary Knox in 1913 offered to Colombia an additional payment of $\$ 10,000,000$ nominally for the exclusive right of way for a canal across the impossible Atrato route and the "lease" of two small islands.

\section{MEXICO AND PROTECTION}

All doctrines of protectorates and of the Canal as a "coast line" are confused by the present status of Mexico. Till 1911 everybody seemed to suppose that Mexico was definitely on the list of well-behaved and permanent commonwealths. It had its nominal federal republican government, its courts, its army, its railroads, its orderly finances ; it paid the interest on its debts, invited foreign capitalists to invest in all kinds of enterprises and gave them fair protection. The Mexico of Diaz furnished no excuse for completing the "coast line" 
between the Rio Grande and the Canal Zone. The present Mexico is a terrible problem. At the end of four years of revolution, it seems as far from peace and a settled government as at the beginning. Mexico is our intimate neighbor, having a common boundary of 1810 miles from the Gulf to the Pacific. The business of Mexico is interwoven with that of the United States through railroads and concessions.

At the same time, Mexico contains a large number of aliens from Europe who under ordinary circumstances would look to their own governments for protection. For three years the United States fended off those governments by giving them to understand that the reconstruction of Mexico was an American question. Following out this policy, the United States declined to recognize President Huerta on the ground stated by President Wilson :

"We can have no sympathy with those who seek to seize the power of government to advance their own personal interests or ambition."

The special interest of the United States was clearly admitted by the British Premier, Mr. Asquith, in a public statement November 10, 1913 :

"There have been rumors that after the United States had adopted a line of their own in regard to Mexico, we took a line calculated deliberately to thwart America. There is not a vestige of foundation for such a rumor."

By common consent, therefore, the United States was left free to straighten out the Mexican crisis if possible; and she tried both mediation and intervention. Mediation, or as it was commonly called, "watchful waiting", failed because the factions in Mexico did not wish to mediate, but to annihilate their enemies. The prohibition of the export of arms to Mexico, issued in March, 1912, by President Taft was withdrawn by President Wilson as "a departure from the accepted practices of neutrality.” A lack of respect for the American flag led to a joint resolution of Congress, April 22, 1914 :

" That the President is justified in the employment of the armed forces of the United States to enforce his demand for unequivocal amends for certain affronts and indignities committed against the 
United States. . . . That the United States disclaims any hostility to the Mexican people or any purpose to make war upon Mexico."

The President thereupon sent to Vera Cruz an expedition which captured the place and occupied it from April to September, 1914. During this time the A B C powers offered their good offices and worked out a scheme for the settlement of Mexico, which seemed likely to be accepted by the leading factions. Again the victorious faction divided into rival bodies, and Mexico was again thrown into anarchy. Enormous quantities of foreign property were destroyed and lives of some Americans were taken. Foreigners, especially Spaniards, were roughly handled by the revolutionists. Probably in the whole history of Latin America no such crop of damages and claims was ever sown as in Mexico.

After four years of warfare the country was no nearer peace, and the United States was no nearer a decision as to how it should deal with a long-drawn out civil war within her nearest neighborhood. European powers were diverted from this question by the breaking out of the Great War in July, 1914; but by holding back from intervention in Mexico, they have thrown upon the United States the moral and political responsibility for reaching a solution somehow. And the United States hesitates because of the prophecy stated by a general of the army: "If we ever get into Mexico, we'll never get out again." Annexation of Mexico would not fit into any form of the American Doctrine.

\section{FIXED POLICY OF PROTECTORATES}

Three administrators, Roosevelt, Taft, and Wilson, have for ten years been pushing the influence of the United States into Latin America, by their combined policy of gold and steel. If the Senate ever ratifies the treaties, the United States will be enlarged by bringing within our sphere of influence a complex of countries, islands, and naval bases, which will be practically territory of the United States.

This policy leads in the direction of annexing the whole island of Haiti with its two republics, and all Central America, with its five States. If that is accomplished, the United States 
will possess or control three West India Islands (Cuba, Porto Rico, and Santo Domingo), and six mainland dependencies (Nicaragua, Honduras, Guatemala, Salvador, Costa Rica, and Panama).

The country may as well face the danger of an expansion which will make it responsible for twelve million people of whom not one fiftieth can speak English, and not one twentieth have ever shown a capacity for self-government. They are accustomed to the rule of the sword. They have traditions and standards which are strange to Washington. The main reason put forward for taking them is that otherwise they will go to smash; that they are practically bankrupt; that Americans lend them money and sell them goods and cannot collect.

That is hardly an encouraging point of departure for making future territories and States of the Union. If these new protectorates are not to be future States of the Union, they will be colonies, and will thus go back to the status from which their fathers revolted a century ago. Uncle Sam has done well with the Philippines and Porto Rico; he has been a good friend and aid to Cuba; but there is a limit to the size of the family - which the most good-natured uncle can bring up to advantage. It will be a queer family with two kinds of children: the legitimate forty-eight equal sisters, and ten others darker in color who are not to be admitted to the common living room but enter into separate apartments of their own by a side entrance. Is that "government of the people, by the people, for the people"? 


\section{Chapter XXI}

\section{RELATION OF THE AMERICAN DOCTRINE TO COM- MERCE}

THE WEST INDIAN THEORY

In all the various statements of the Monroe Doctrine, official and unofficial, the motive put in the foreground has usually been the political - foreign policy, territory, conquest, treaties, effect of democracy, paramount interest. One of the tickling things about the Doctrine is that it adds to the national selfconsciousness of being a great power in the world. The American eagle screams partly because he likes to hear his sounds re-echoing among the crags. When Secretary Fish made the impolitic statement that the United States had a "leading voice" in North America; when Secretary Olney unchained his doctrine of the "fiat" and "sovereignty" of the United States, they were saying those things partly in order to show the world that they dared to say them. Another motive which undoubtedly was always in the background was the commercial interest of our country, but it was never distinctly stated as a significant force till Fish, in the despatches just referred to, talked of "commercial connections" and "the development of a peaceful American policy."

The idea that West Indian trade was the chief motive of the Monroe Doctrine has been discussed earlier in this volume. The argument against this view is that there was good trade both before and after the Declaration. From 1783 to 1823 there was plenty of trade with the British West Indies. in British bottoms; and with French, Spanish, and other West Indies in American vessels which braved the dangers of limited and contraband trade. After 1823, for a good twenty years the colonial systems of Great Britain, France, and Spain remained an impediment to trade in the West Indies. England under 
pressure from Jackson, and a system of "countervailing duties" passed by Congress, admitted American vessels in 1830, and in 1849 gave up the Navigation System altogether.

The new states admitted imports on nominally reasonable terms, except that there continued a vexatious system of fines or duties on the transit of imported goods. The Monroe Doctrine placed no restraint on the right of the Latin-Americans to make such commercial treaties as they chose, provided there should be no preference to any European power as against the rest of the world.

The total South American trade at this time was not large, and the United States probably got a fair share. Few of the modern tropical and sub-tropical staples were then exported. The trade in fruit, rubber, frozen meats, and nitrates was not yet set in motion. The most that our ancestors could expect was that they should have as good an opportunity as any one else to develop reciprocal trade. The North Americans were handicapped by a lack of capital. They founded few importing and exporting houses outside our boundaries. They were not yet a manufacturing country. Foreign trade in all directions did not bulk so big as it does nowadays.

\section{POLICY OF RECIPROCITY}

The turn of feeling on the subject of trade with Latin America, and the reciprocity acts of 1890 and 1897 have already been discussed. After 1870, two parallel forces brought into relief the commercial motive in America. These were, investments and surplus manufactures. Cuba always had a stable govêrnment, and Mexico after Diaz came to power in 1879 invited investments. Money therefore poured into these countries to build railroads, to open mines, to develop agricultural estates. In Mexico particularly the railroads had a subsidy from the government; and those who desired concessions of other kinds found means of convincing the authorities. With these investments went a considerable number of American citizens with their families. Thousands of business men throughout the Union had interests in Mexico and knew something of LatinAmerican conditions. Their thrift and far-sightedness quickened the pulse of Mexico, in which the revenue and the exports and imports rapidly increased. Thus investors at home and 
active men in the various Latin-American countries came to have the strongest personal interest in calling for the support and backing of the United States.

For a long time, American manufacturers were little interested in Latin-American trade, or indeed in any export trade. . They found a sufficient market at home. Higher organization and greater capital so increased the product that manufacturers began to push into the markets of Europe, Asia, and Africa, and they became interested in Latin America. Still the American exchanges were comparatively small; and Blaine's policy was to come to an understanding with the Latin-Americans by which we should graciously receive their raw materials at or near a free-list.

The McKinley Act of 1890 and Dingley Act of 1897 broke down, apparently, because manufacturers saw that American producers of hides, timber, and other raw materials would take note of new competition and refuse the votes necessary to keep the tariff intact. Meantime, several European powers, especially France and Germany, engaged in tariff controversies with the United States; and the reciprocity provision of the Dingley legislation of 1897 was in part intended to bring them to terms. That was accomplished, but the treaties with the Latin-American countries were relentlessly hung up by a protectionist Senate.

Since that time no progress has been made toward a commercial system which shall give especial advantage to the LatinAmericans. So far as their products are admitted free, it is because they come within the class of raw materials, which the Underwood Tariff of 1913 expected to encourage. Whatever the chance may have been of definitely attaching Latin-American powers to us by commercial ties, nothing has so far been accomplished. The heavy export of fruit, which has become a great industry, has to compete with the protected fruit of California and Florida; hides, which had been indefinitely on the free list, were taxed by the Dingley Tariff of 1897 . So far as our exports go, they are received by the Latin-Americans on the same customs conditions as those from other nations, and the rivalry is simply one of prices and terms. So far as imports into the United States go, they are on the whole unfavorably treated, because they are included in great classes of goods which are subject to duty. 


\section{SHIPPING}

From the beginning of the Latin-American states there was trouble over their documenting ships which were not built by them, were not owned by them, and, in some cases, had never seen one of their ports. Monroe's Administration was lenient to these vessels, many of which carried commissions as privateers, and some of which were no better than pirates. That immediate difficulty faded away, but has arisen in a new form through the efforts of the A B C powers to construct navies. Brazil had a few armed ships while still an Empire, and all three powers wish to be in a position to defend their ports and to attack at least the commerce of states with whom they may be at war. It is difficult to keep up this status of naval powers by countries which do not build even merchant ships, and which are dependent for their commercial connections upon ships flying foreign flags.

Throughout the United States there is a widespread belief that shipping has a magical effect upon commerce, - " "trade follows the flag." The notion extends to the impression that the flags of ships of war in foreign ports somehow help to sell goods. The United States is keenly alive to the fraction of South-American trade that comes to her, and has therefore for twenty-five years made subsidy payments, ostensibly for postal service to American ships plying to various Mexican, Caribbean and South American ports. During the whole of that period, efforts have been made to secure general subsidy bills, which would include lines to Latin America. The postal subsidies in the last year of record amounted to about $\$ 350,000$ for trade to other American countries.

The whole subsidy question is tied up with the tariff question. So long as Congress is unwilling to make concessions on the raw products of other American States, we cannot expect to have cargoes for a large shipping. To pay money subsidies to ships in order that they may be satisfied to carry light cargoes, is preposterous upon its face. Our government must take one ground or the other : either it must build up the trade, both by easing the tariff and by facilitating the supply of direct ships; or it must receive what American trade comes without special inducements and let the shipping take care of itself. 


\section{INTERNATIONAL CONTROVERSIES OVER THE CANAL (1850-1900)}

The most powerful modern influence upon shipping is the waterway across the Isthmus of Panama, the history of which in connection with the American Doctrine has been discussed in several previous chapters. Interest in the Canal is as old as interest in America, but for many years the task seemed so great and the complications so many that there was a general understanding that it would be built under joint international control, and would be a neutral highway open to commerce and to the navies of the world, both in peace and war. For that policy was substituted, in 1850, the Clayton-Bulwer Treaty which was an official admission that Great Britain and the United States had equal interest in the Canal. At that time it was thought that other powers would enter into this association of nations, but nobody came forward with the necessary capital ; and as vessels increased in size, the dimensions, cost, and difficulty of a canal constantly loomed up larger.

Secretary Seward, Secretary Fish, and Secretary Blaine all saw the need of dissolving the partnership with Great Britain, and they all tried to undermine that agreement by separate treaties with the Isthmus powers to back up their argument. Fish, Blaine, and, later, Olney dwelt upon the danger to Latin America from close contact with Great Britain as a partner in the Canal. The British government played into the hands of the United States on that issue by its exasperating and repeated attempts to get a footing on the Mosquito Coast, which would have brought it to the mouth of the San Juan River, next to the outlet of any possible Nicaragua Canal. This action gave ground for the repeated insistence of the United States that the Clayton-Bulwer Treaty had not been kept in good faith; and led to the belief that the British were determined to acquire a strategic point on the flank of what many people supposed to be the best route.

For a long time the Isthmus of Tehuantepec was looked upon as a possible route for a Canal, or, at least, a railroad which would make the necessary link from ocean to ocean; and a permit to use it was secured in the Gadsden Treaty of 1853. After 1870 , it became clear that there were only two likely routes: Nicaragua and Panama; and that accented the diplomacy of the United States with Nicaragua and Colombia, and with some 
of the other Central American states. Honduras and Nicaragua made canal treaties with the United States, expecting that our government would finance, or build, or control the Canal. The United States several times took advantage of its treatyright with Colombia to protect the Panama railroad which was a practical statement of her peculiar interest in Latin America in general and the Canal in particular.

The French Canal Company broke into this confidence that sooner or later the United States would build the Canal; but the republican government of France, warned by the experience of the Second Empire in Mexico only about twenty years earlier, declared point-blank that it had no government concession or interest in the Canal; that the Company was a private concern which raised its own funds and made its own arrangements with Colombia. As matters turned out, this assurance proved true; the government had no desire to back up a bankrupt corporation which scandalized France by its purchase of newspapers and deputies. If the Canal had been the expected success, France might have looked at matters in a very different light.

\section{INTERNATIONAL LAW OF THE CANAL (1901-1905)}

The Canal as a fixed international fact begins when, by the first Hay-Pauncefote Treaty of 1900, Great Britain agreed to withdraw from any share in construction or control. The second and operative treaty of 1901 includes that principle and adds a formal abrogation of the Clayton-Bulwer Treaty. The position of Great Britain during the previous fifty years was not founded on international law, but on the treaty consent of the only power which was in a geographical position to contest British influence on a canal. Both forms of the Hay-Pauncefote Treaty, however, included substantially a reprint of the rules of the Constantinople Convention of 1888, which were to be made to apply to the American Isthmus Canal.

Are those rules international law? They were signed by most of the European powers, but for more than fifteen years were not put into operation, simply because it was convenient for Great Britain to exercise a dispensing power upon them. When in operation they are sufficiently one-sided, inasmuch as they authorize Great Britain to protect her posts in the Red 
Sea. In terms, the Suez Canal was open to all nations in time of peace and neutralized in time of war. German, Austrian, and Turkish vessels of war have a treaty right to use the Suez Canal in the present European war; but everybody knows that the right is a delusion; that the Canal is used and usable only by Great Britain and her allies in time of war.

The idea of equal commercial use which appears in the first suggestions of the Canal back in 1826, has been realized because the United States so agreed in the British Treaty of 1902, and also in the Panama Treaty of 1903, and has carried out those pledges in legislation. The precedents of the world are in that direction: the Suez Canal, the Lower Danube, the Belt between the Danish and Swedish coasts, and some other natural and artificial waterways are protected by treaties. The Danube is administered by an international commission. The underlying idea would seem to be that a great artificial canal is to be subject to the common use like a natural strait, such as Gibraltar and the Dardanelles. This equality is of little direct consequence to the Latin-American states because not one of them is a commercial shipbuilding country. They all depend on foreign shipping. Indirectly, it puts them on the great lines of traffic, and equality of tolls gives them access to cheap services.

The question whether the United States may give special low rates to her own shipping has been raised and settled in the negative. By the act of 1912 a discrimination was enacted for American ships bound on voyages from one coast of the United States to another. By the act of 1914 this privilege was repealed. Here again the example of the Suez Canal was called in, for Great Britain gives no advantage of tolls to her own vessels in that waterway.

The question of the fortification of the Canal, which was violently discussed for several years, has also been adjusted, and the fortifications are there. If the question had been decided otherwise, it would now have to be reconsidered in view of the terrific offensive power of modern guns and aëroplanes. Some of the Canal locks are actually within range of the heaviest naval guns operating from the sea, and it would be folly to leave the defenses in such shape that any great naval power which declared war without notice might destroy this artery of the United States before naval aid could reach it. Fortifications, 
bigger fortifications; garrisons, and larger garrisons, - are certain to be demanded, and may be needed.

The provisions as to the use of the Canal by warships are workable only in wars in which the United States is not a party. It is therefore a remarkable fact that, though warships have often appeared in the ports at the ends of the Canal during the present war, no battleship of any nation has made use of the Canal. As for the use of the Canal by enemies of the United States in time of war, it appears to be in the treaty but it is not in the Canal. It is easy to disarrange a delicate piece of mechanism at the lock gates; it is simple that a barge should accidentally sink in the channel; a United States submarine could conveniently operate off Colon or Panama; hence nobody need expect that the Canal Zone will ever see a hostile armed ship upon its waterway. It is one of those cases of promising the impossible, against which Colonel Roosevelt has so often declaimed.

\section{EFFECT ON THE COASTING TRADE}

The instinctive reason for constructing the Panama Canal has been nearly the same as that for building the Pacific Railroads. Both systems are hooks and bands to bind the Union together. The railroads will always be the carriers of most of the through, high-class freights, and of nearly all the passengers, because they are so direct, swift, and regular. The Canal will act as an equalizer on railroad rates. The Canal bids fair to be the highway of heavy bulk freight, lumber, coal, ores, foodstuffs, fruit, raw and manufactured iron, machinery, and the like, and will take part of the tourist and trans-Pacific travel. The exact current of this traffic is not yet defined. It is hard to see why any shipments to the Pacific Coast should be made through the Canal from points west and southwest of a line drawn through Chicago, St. Louis, Oklahoma City, and El Paso. Chicago freights must go 1000 miles to New Orleans and 5000 miles by water in order to reach Portland, which is only 2300 miles away by direct rail.

From the Atlantic and Gulf Coasts to the Pacific Coast the Canal offers a route which will develop a heavy trade. The fish, grain, and lumber of the Pacific Coast States will find a convenient outlet. It must not be forgotten, however, that canals create no trade and build no cities. They take the trade 
that naturally develops. Hence, places like San Diego, which are on or near the main steam line, will prosper as ports only in proportion as they furnish goods to export. As a political agent, the Canal undoubtedly tends to good feeling and common understanding between the Atlantic and the Pacific Coasts.

The Canal, also, will be a great highway from the Gulf and Atlantic Coast to Asia. But it cannot much increase the total shipments from the United States to Japan and China. Those shipments have already a very good short sea route from Puget Sound ports, Portland, or San Francisco, with excellent railroad connections from the Eastern States. Lines of ships are already planned to run from New York through the Canal to Japan and perhaps to Australia, and they will somewhat cheapen trans-Pacific transport; but the only way to enlarge international trade is for both sides to sell more to each other.

A cross-connection with the American Doctrine which affects the Pacific and Asia, is that the Canal puts the United States definitely nearer than Japan to the West Coast of Mexico and South America. It makes it more difficult for the Japanese to think of getting a footing somewhere on that coast, and it brings us closer to the Japanese Doctrine against European or American control of Asia.

\section{THE CANAL AND LATIN AMERICA}

We hardly realize that the geographical lay of the land is such that every part of South America is farther east than Savannah ; and that the Canal is on the same meridian as Charleston and Pittsburgh. Hence the new water route gives not the slightest aid nor advantage to the best and broadest parts of South America. What it does for that continent is greatly to shorten the sea voyage from American or European ports to the four coast states of Western South America. From those coasts railroad lines will eventually cross the Andes at several points, in order to reach the fine country on the upper waters of the tributaries of the Amazon. The rich areas on or near the middle and lower waters of the Orinoco, Amazon, and La Plata will always be tributary to the east coast. That is, the Canal gives a better access only to $14,000,000$ South Americans, many of whom live east of the ridge of the Andes; while it does not in the least 
improve the physical or moral connections with nearly forty millions of other South Americans.

Whatever the new trade advantage may be, it is from the start shared with European nations, which already have their strong trade connections in that part of the world. This has been an unprogressive region even since the breakdown of the Spanish Empire, with the exception of Chile, which has another good road to Europe through the Strait of Magellan. There are rich mines, most of which, however, would furnish little freight. Otherwise export products are few. Nobody will ever get immensely wealthy out of the trade of Colombia, Ecuador, and Peru.

In North America, the Canal opens up the western coast of Central America and Mexico and gives them for the first time direct access to the world's markets. The railroad across the Isthmus of Tehauntepec is a short-cut rival for part of this trade; but Western Mexico and Lower California are put on the map by this new connection. These however are mountainous countries with narrow valleys and belts of sea-shore. The interior of the Central American States and parts of Mexico are rich in fruit, coffee, and rubber; and the political influence of the United States is so strong in those countries that the Canal will certainly open up profitable trade.

Here is where the American Doctrine will have nèw opportunities. With Nicaragua practically governed from Washington, and Honduras and Guatemala on the waiting list, the Canal will serve to strengthen the commercial and governmental ties which are binding those countries fast to their greater neighbor. The example will not be lost on the South American States. Colombia in particular lies just outside the Canal area, and several successive Secretaries of State have tried very hard to pay damages to Colombia for the loss of Panama and thus reëstablish friendship. Colombia feels herself despoiled and robbed, and even the formal apology which Secretary Knox introduced into his treaty which the Senate did not ratify, could hardly take out the sting.

The Canal means closer touch with the Latin-American states; more travellers; more commercial men; more investors. In the disturbed states it will mean also more friction; more seizures of property ; more danger to life; more claims, more arbitrations, more treaties, - possibly more intervention. 
The attitude of the United States in the protectorates of the West Indies and Central America is distinctly against better feeling and larger influence among the powers brought nearer to us by the Canal.

The country most likely to be affected politically by the Canal is Mexico. To say nothing of the "coast-line" argument, it is going to be convenient to trade with both the east and the west coast, to send war vessels and to make landings. Intervention may at any time put Mexico in the position of a protectorate; and if independence is preserved the Canal means a great distribution of American citizens, enterprises, and capital : that is, a greater growth of the commercial ties which move ever forward toward annexation.

\section{GENERAL QUESTION OF COMMERCE}

All these discussions of routes bring into relief the main question of a possible special relation, or combination, or commercial alliance, between the American states. Ever since the first Pan-American Congress in 1890, the idea of an American customs union has been on the carpet. The success of the German Zollverein in aiding trade and preparing the way for a political union is cited as an example. The problem of a customs union between small, adjacent, and interlocking states dependent for their outlet on a few common ports, is very different from that of the scattered continental and island countries of America, and is subject to many special difficulties.

(1) The United States has not been able to come to terms with our nearest neighbor and best customer, Canada. The reciprocity treaty which existed from 1854 to 1866 grew very unpopular, and the theory of reciprocity is usually opposed by the high-tariff sentiment. When by greàt exertions President Taft secured an act of Congress which would make a system of Canadian reciprocity if the Canadian Parliament passed a similar act, the Canadians held back. The two efforts of 1890 and 1897 to secure reciprocity treaties with Latin America broke down. The conclusion cannot be resisted that the United States does not desire special tariff relations with our neighbors, or, if brought to that point, the neighbors hang back. An American customs union without Canada would be very incomplete. An American customs union which would include 
Canada, Brazil, and Peru would strike great diversities of interest.

(2) Where would such an alliance land the American Doctrine, which never would have come into being but for the expectation and intention of Great Britain that the Latin-American powers should trade freely with Europe? For the United States to take part in a customs union which would greatly diminish European trade would be to invite protests and threats of reprisals from Europe: All-American trade might provoke All-European trade.

(3) The differences of natural interest between two manufacturing and protective countries, the United States and Canada, and a group of agricultural and mining communities, whose interest is free trade in their exports, are too great to be confined by an alliance of this kind. The rival schools of industry can fight it out in our own Congress at Washington, which by a small majority passes a bill that becomes law. It is hard to conceive of any International Tariff Congress which could frame or sustain a uniform scale of import duties for all American countries. Or, should the alliance have several scales? Would the Western farmer stand the strain of competing imports of grain from the Argentine? Would the California fruit growers give up their advantage against Jamaican fruit? Would the copper miners of Butte allow free imports to come from Mexico?

(4) A manifest tendency of a customs union would be that it might lead to a political union, a real Pan-America. The difficulties of such a union have been discussed elsewhere. Whether it would or would not be a good thing, there can be no doubt that the apprehension of such a result would be one of the most powerful influences against any customs union. Nothing but a rearrangement of the forces of the world which would fill all America with the terror of invasion, can bring together these diverse elements into a commercial or political union. 


\section{PART VI}

\section{DOCTRINE OF PERMANENT INTEREST}

\section{Chapter XXII}

\section{SEARCH FOR THE DOCTRINE OF THE FUTURE}

\section{AMERICAN DEFINITIONS OF THE MONROE DOCTRINE}

THE attempt to define what the Monroe Doctrine has been and is, will be of little use unless it throws some light upon the form which the interrelations of America are likely to take in the future. Has the so-called Monroe Doctrine been a permanent policy, or is it simply a succession of declarations, each serving an immediate purpose, and added to its predecessors as a boy strings his catch of fish on a cleft stick? That no agreement has been reached upon the critical question - what does the Doctrine now mean? - may be seen from a few of the current definitions. To the mind of Admiral Chester, of the United States Navy:

"The Monroe Doctrine is the cardinal principle of the foreign policy of the United States. It has been so construed for nearly one hundred years of our national history, and it so remains to-day. ... . Two distinct and far-reaching principles are laid down in the Monroe Doctrine. The first is the principle of 'self-defense.' Self-preserva-

Self-

Defense and Protectorates. tion is the first law of nature, and it is the first law of nations. In the case of the United States the national defense required, when the doctrine was enunciated, that the country should hold a protectorate throughout the entire western continent. The second principle is that South American republics, which followed our lead in declaring their independence, should have our protection in maintaining this doctrine for themselves." 
Major McAndrew, of the Army, in a searching article in the Infantry Journal (1911), gives it the following meaning:

"The Monroe Doctrine has come to mean that the United States will not only oppose any attempt of a European and it Guardianship of America. may as well be added, an Asiatic, power to acquire territory on, or to extend its influence over, any portion of the Western hemisphere; but that it constitutes itself the guardian and protector of all American states, that it will not permit any Old World nation to intervene or to interfere in the political affairs of an American state, no matter what the cause. It means that to the United States belongs a prominent place in all American affairs, and that its responsibilities or power in that respect will not be shared with any European or Asiatic nation. It means the doctrine of 'permanent interest of the United States.' In support of this principle the American people are at all times willing to go to the extent of war with any

Defense of American Principles. nation disrupting it, no matter how strong our probable adversaries may be.

"We will not admit that there is room for arbitration, even where the principle is involved. . . The American people are not disposed to submit to arbitration a question that involves the Monroe Doctrine. . . .

"The present Monroe Doctrine is even an extension of the broad policy declared by President Polk in 1845, which was in effect, that the United States would never acknowledge any transfer of territory, whether made even by the desire of the inhabitants, by purchase or by force, from any nation of North.America to any nation of Europe. This is the basis of our "traditional policy."

A more critical and unfavorable view is that stated by Hiram Bingham, in his article "Should we abandon the Monroe Doctrine."

"Whatever our foreign policy happens to be for the moment, it is called the 'Monroe Doctrine.' Do we decide to intervene Variableness of the Doctrine. in Cuba, we do not say that we believe it to be for our best interests as a nation to overstep the bounds of international law and to carry our intervention into a neighboring territory.... Do we wish to take any part of Spanish-American territory which we need or which is being badly governed? We refer our actions to the Monroe Doctrine. It is no wonder that Monroeism, as it is called in South America, has come to mean to the Latin-American mind interference, intervention, tutelage and patronizing insolence." 
Among many definitions propounded at the Clark University Conference of 1914, Professor Callahan's summary is as follows :

"Under whatever name, and however modified to suit the conditions and needs of American foreign policy, it is still a useful principle. It may fitly be called the doctrine of na- Doctrine of tional defense, which in its results may be regarded Defense. also as a doctrine of Pan-American defense. In America the United States government has duties and responsibilities which cannot be abandoned to the mercy of trans-oceanic powers, nor submitted to the decision of international conferences or tribunals. It must attend to the larger interests of the United States - without any unnecessary interference with the larger interests of other powers. . . . Peace in America, on the basis of good government, is more important to the United States than it is to Europe, and more important to the United States than peace in Europe.

Peace and Interest.

"The present basis of policy is the paramount interest of the United States in American affairs - a special interest which, especially in the Caribbean, can be shared with no other power, and perhaps would be questioned by no European power."

Philip M. Brown, formerly minister to Honduras, said before the American Academy of Political and Social Science :

"If we will reduce the Monroe Doctrine down to its simplest terms; if we will strip it of all the vagaries of statesmen and commentators, we find in the last analysis that it means nothing more and nothing less than that the United States finds itself pledged to the defence of the rights of every nation to independence, sovereign jurisdic-

Sanction to Bases of International Law. tion and equality. These are the most sacred, basic principles of international law; and nothing could be more securely a part of international law than an effective sanction of these principles. Such a sanction is to be found in the Monroe Doctrine, which, interpreted in this light, ceases to be simply a question of policy, and is at once put on the solid basis of law."

Tucker, author of a well-known book on the subject, at the same Conference has stated his view as follows:

"What is this doctrine? It may briefly be defined as a warning to the governments of the Old World not to establish colonies on, or to extend their political systems to these continents, and to 
refrain from interference in the affairs of the Spanish-American republics. Conceding that the Doctrine has no place in the realm Warning to of international jurisprudence and that it is hardly Europe more than a fiat, we are confronted by the fact that its assertion by this government has more than once received the attention of European powers, and it has been, in a certain sense, recognized by them in the happy adjustment of the contentions which has occasioned its avowal."

\section{FOREIGN DEFINITIONS OF THE MONROE DOCTRINE}

Most of the foreign writers, especially the Latin Americans, look upon the Monroe Doctrine with suspicion, if not with positive dislike. Hector Pétin, a French lawyer, in his elaborate book Les Etats-Unis et La Doctrine de Monroe (1900), says, -

"The Monroe Doctrine was a local and accidental solution. The promise made by Monroe not to intervene between Europe and European colonies, the implied promise to limit American ambition to America only, were associated doctrines imposed on the President by the circumstances and distinctly dictated to him by the very prudence of his message. In the process of evolution, the Monroe Doctrine has been transformed: from abstention it has altered into action. It has become more and more bold, progressive and even aggressive. Transformed by Polk and his successors into an instrument of expansion, it has more and more developed the germ of conquest, while at the same time by its substitution of an American law for the general law of nations, it has expressed a contempt of law. . . I Imperialism ignores all rights and all duties; it lays down as a single rule that interest overtops rights."

Another lively French writer, De Beaumarchais, writing in 1898 on La Doctrine de Monroe, expresses the same view that the Monroe Doctrine is a short road to empire.

"The Monroe Doctrine - such is its name - in fact influences all the foreign policy of the United States; it includes a solution for all the international complications which could arise; it dictates to the government of Washington a duty which it could not ignore without violating all historic precepts, without betraying the country. Defensive at the beginning of the century, the same doctrine has become offensive; formulated to prevent Europe from advancing in America, it to-day orders Europe to recoil. ... Wonderfully habile, the Monroe Doctrine in fact 
is used to authorize political measures of the greatest variety and to legitimatize them all. Its title of 'Doctrine' has contributed to its success by giving to the decisions which it invokes, a judicial look, which is bound to please a people upon whom the words 'law' and 'legality' exercise so reasonable an influence. The import of the Doctrine has been speedily ignored; at least people had forgotten to what particular conditions it had made allusion; people remembered only those applications which had enlarged the country, and they made of it a principle of universal range."

A more recent writer, the Marquis Barral-Montferrat, encouragingly introduced by the renowned Comte d'Haussonville, in 1905 published his little book De Monroë à Roosevelt, in which he scourges Uncle Sam.

"American Imperialism, with its enormous pride and its insatiable ambition, imperialism as nine-tenths of the citizens of the United States understand it without enough courage to admit it, imperialism as the President in office with his habitual obstinate pride is not afraid to define it, is already completely on the spot. In fact what the United States more and more desires is to become one of the greatest powers and perhaps even the greatest power of the world. In fact, to reach this result, the Americans are ready to risk much. Even to those who tell them to look out $\mathrm{Mr}$. Roosevelt is ready to answer that steady expansion is a natural law of every active organism, and that to follow this law is to note proof of a wisdom greater than the greatest wisdom of those who think they are wiser because they show themselves less confident."

Several of the Latin Americans have already been quoted in deprecation of criticism. The Uruguayan, Capella y Pons, as recently as 1913 in his Monrö̈sme sees something more friendly in the attitude of the United States.

"The Monroe Doctrine, that which was conceived by the patricians who placed the foundations of the great republic; and which is the only one which for that reason could be called 'traditional,' has remained unchanged and unchangeable. It is that which all the people of the [South American] Continent feel to be enlarging in proportion as they form themselves into independent nations. . . . The real Monroism, in a word, is that which incorporates the policy of independence, of freedom and of brotherhood among the American states, and which refuses to recognize as legitimate, exercises of power from without which would change the system of national organization which they have deliberately adopted." 
The most recent and the most thorough investigator into the Monroe Doctrine, Herbert Kraus, takes a legal view of the whole situation.

"No point of view remains from which the Monroe Doctrine could be justified under International Law. For the defense of the Doctrine, references have frequently been made to the existence of a supremacy of the United States over the other American communities, especially since the participation of the United States in the controversy on the Venezuela boundaries. If by 'supremacy' is to be understood the existence of an actual political leadership by one nation in a particular group of states, then in fact there is such a supremacy for the benefit of the United States in America. . . . This fact is, however, by itself, unsuited to furnish a legal justification for the Monroe Doctrine."

\section{OBJECTIONS TO THE MONROE DOCTRINE ANALYZED}

To know what the Doctrine must be, we should take note of what it ought not to be. For convenience the numerous objections may be classified as follows, without supporting each by quotations :

(1) The doctrine has been unevenly applied. For instance, while the United States was protesting against the French in Mexico, during our Civil War, she did not try to stop the Spanish attempt to reconquer Santo Domingo. We have protected Venezuela against England, but not Chile against Spain. Haiti has been protected in order to save its financial soul, but Ecuador is allowed to go on sinning.

(2) The fears which caused the original Monroe Doctrine and many of the renewals have never had a sound basis. The Holy Alliance would have let Latin America alone if Monroe had kept silent. No European power has been tempted to take possession of American territory except France, in 1861. No great power now looks with longing on America.

(3) Several of the Latin-American peoples have come out of the conditions which suggested the Monroe Doctrine and are no more to be considered as subject to it than Portugal, or Sweden, or Greece; and the other Latin-Americans may safely be left to the influence or control of the strong states.

(4) The Monroe Doctrine has always been unilateral. The United States expects of its neighbors a degree of good order 
and respect for aliens which she is not able to enforce in her own territory. The United States also demands of Europe a self-denial toward America which she has never practised. Five regions now within our borders - Texas, New Mexico, California, Porto Rico, and the Canal Zone - have been annexed at the expense of a Latin-American power since 1823. Therefore the Doctrine has been anything but a protection to Latin America.

(5) The Monroe Doctrine is not a protection to the United States, since it involves us in quarrels not our own; and since the modern forms of the doctrine have led this country into the policy of scattered dependencies, which add seriously to the cost and difficulty of defense.

(6) So far from securing peace, the Monroe Doctrine has done nothing to bring about concord and union among LatinAmerican powers; it has not prevented several wars with the United States, nor several military interventions by the United States.

(7) Neither the original Monroe Doctrine nor any form of the American Doctrine has ever been brought within the text of an act of Congress or a treaty, either with Latin-American or European powers. It has been formally excluded from the Hague Conventions. It has, therefore, never been sanctioned by the American people and there is no sufficient evidence that they favor it.

(8) The Monroe Doctrine tends to bring the United States within the field of military nations and thus to destroy the position of peace to which our geographical situation and the desire of our people entitle us. To maintain the Doctrine calls for a military expenditure and spirit in the United States which will be a harmful influence in the world.

\section{THE AMERICAN DOCTRINE AS A UNIVERSAL PRINCIPLE}

How can we get rid of the practical difficulties which beset every attempt to frame a consistent remedy for the troubles of America? How can we at the same time make a Doctrine which shall correspond to the present conditions of mankind? For any form or application of the Doctrine which is not rooted in the character of nations and the relations among them is doomed to fail. 
One sure defense of the principle, one reason for thinking that it is necessary and permanent, is that corresponding doctrines have been evolved in all ages; and several of them are now in operation in other parts of the world. From 1850 to 1890 there was a baleful Monroe Doctrine of the Near East, to defend which France and Great Britain went to war with Russia. There is now a Monroe Doctrine of the Balkans, in which Russia has taken something like the leadership asserted in America by the United States. Another Monroe Doctrine protects northwest Europe; interference with Belgium or with one of the five small States, has been felt by France and England to be a challenge. A Monroe Doctrine, as we have seen, is rising in Eastern Asia.

The most significant of all these warning signals is the great Monroe Doctrine of Europe, which would at once be aroused if any extra-European power should seek to plant naval stations or protectorates or colonies where they might threaten Europe. Suppose the United States were to fortify Liberia as a naval and military station, or should negotiate for the Balearic Islands in the Mediterranean. Would that be simply a local question between the powers concerned and the United States? Japan is becoming a great world maritime power, to which the Azores would be a very convenient naval station. Would England or Germany accept without protest an effort to plant a new center of friction and excitement and danger by an Asiatic power on the approaches to Europe?

These objections of single powers and groups of powers to a disturbance of the present conditions rest upon a solid bbasis, which is deeper and stronger than international law, because all international intercourse and all treaties must accommodate themselves to it. When in the course of years a group of nations has come to an equilibrium of boundaries and ports and approaches by sea, everything defined and understood, the proposal of an outside power to settle in that field, even on a very limited area, is looked upon as an affront. The protest would be still stronger when the new territory comes out of the flanks of a great established power, jealous of its own prestige. Since the Greeks a hundred years ago fought their way into nationality their kingdom has been a poison to the Turkish Empire. The King of the Belgians for his own profit founded a company to exploit the Congo River, and suddenly the 
nations found a new European colony planted in the midst of the French, German, English, and Portuguese possessions. Whatever the weakness or the imperfection of the Monroe Doctrine, it is simply a re-statement for America of a timehallowed European and Asiatic principle.

\section{PROTECTION TO THE UNITED STATES}

The main reason for this principle of "stand-off" adopted by so many nations in various parts of the globe, is that statesmen believe it to be the simplest and surest means of selfprotection. In Europe, as in America, great powers sometimes interfere to prevent changes of the boundary or status of small powers, out of sheer good nature, or out of race consciousness. Russia is interested in nations which have the Greek form of religion and speak languages akin to Russian. England was so good-natured as to make a present of the Ionian Islands to the little kingdom of Greece. In like manner the United States has frequently shown a real spirit of national friendship, a genuine desire to improve our neighbors, - that is, to make them as much as possible like the United States; which is one of the reasons why the Doctrine is not popular in Latin America.

The first duty of the United States, however, as of every other state, is to provide for her own people. No maxim of public policy can stand which is not likely to promote their safety and welfare. The main argument against the new protectorates is that, though they may be useful to other races, though they tame and civilize uproarious neighbors, they do so at our expense. Energy, efficiency, and money which is greatly needed in our internal affairs flow out to those who do not want to be made happier or better or more solvent. In the protectorates, as in previous inter-American relations, the future Doctrine must be founded upon the effort to promote the safety and long life of Columbia, the Gem of the Ocean.

If the Doctrine is not a bulwark to the United States, it never ought to have been born, and it will certainly die out. The argument that the Monroe Doctrine has protected us from European seizures of points of vantage is rather far-fetched, inasmuch as when it first appeared the British were already in possession of Nova Scotia, the St. Lawrence Valley, the northern 
interior of North America, the Bermudas, Bahamas, and Jamaica, all of which might be used against us, and none of which have been thought contrary to the Monroe Doctrine. Doubtless the silent working of the Doctrine has prevented some other territorial changes: Cuba would hardly have remained Spanish so long but for our strong objections to any territorial occupation. Nevertheless, supposed British desires to annex Texas, California, and the Hawaiian Islands, all proved fanciful ; Great Britain cared more about Oregon than California. Still we must remember that Hawaii would almost certainly have been British or French, if the United States had not hovered in a threatening attitude on the horizon.

How far the Monroe Doctrine has protected the United States from direct or indirect disturbance by Europe is hard to estimate because we have had but one European war since 1823 - that with Spain in 1898 . The immediate cause of that war was Cuba, which was much in the minds of those who framed the declaration; but the whole theory of the Monroe Dogtrine was against disturbance of existing colonies by the United States. The real question is, whether we should now have been any more uneasy if European powers had made settlements in America; say, the French in Venezuela, the Germans in Brazil, the Italians in Argentine, the English in Central America. The history of American colonization shows that the mother country of every such colony would have tried to enlarge its boundaries and become more powerful; and that wars with the remaining Latin-American powers would have resulted.

Suppose half of South America had been occupied by nations which are parties to the present European war. The whole Western Hemisphere would have been in a turmoil and the present difficult course of the United States would have been far harder. When everything has been said that can be said about the changes in naval warfare, about the growing ease of sending a landing force to a long and undefended coast, and about the great distance of South America from every part of the United States, - the fact remains that the present distribution of nations in America is not threatening to our peace or welfare; and that a group of European colonies would be a standing menace. 
NO DEPENDENCE ON EXTRA-AMERICAN SUPPORT

A new publicist and a new prophet has recently arisen among us in the person of Roland G. Usher, the author of Pan-Americanism, A Forecast of the Inevitable Clash Between the United States and Europe's Victor. It appears that by "Pan-Americanism" the author does not mean Pan-Americanism, inasmuch as he thinks that is impossible; that by "forecast", he does not mean forecast, but guess; and that "the inevitable clash between the United States and Europe's victor" means no more than that if they clash they will clash. Attention has already been called to Professor Usher's imaginative theory of the commercial reason for the Monroe Doctrine. He has expanded that thesis into a notion that beginning with a demand for "freedom of trade in the Gulf of Mexico" (which has never been demanded by the United States), the country took to enlarging its territory, because "the growth of the cotton culture had now made the annexation of land suitable for cotton our primary interest." Thence by a bridge the piers of which are not visible he advances to the thesis that "the South Americans ... defense from aggression has depended upon the English control of the sea and upon the lack of sufficient motive to challenge it."

Usher's next step is to assert that "the English continued to retain the supremacy of the Western Hemisphere, though they rarely chose to assert it and never demanded formal recognition by European nations or by the United States." Then the building of the German fleet "gradually compelled England to concentrate her own ships in the channel and in the North Sea, and thus robbed her of her physical control of the waters of the Western Hemisphere. . . . They therefore proposed to hand over to the United States the actual control of American waters, and in particular, of the Gulf of Mexico . . . in exchange for an understanding as to the ways in which the United States would use its control of American waters and for an amicable arrangement which would probably lead to close economic relations with the United States. ... The offer was alluring, and was accepted by the United States."

The only trouble with this logical network is that it is made of moonshine. Ever since the Napoleonic Wars the British fleet has been larger than that of any other country, but it has 
had a large task all over the world and has spared little of its naval force for interests like those in the West Indies and the Gulf, which were to England minor issues. How does Usher account for the fact that the United States has for a hundred years made no serious objection to the growth of the power of Canada alongside us? It is because it was early recognized that Great Britain would not and could not use her naval strength to enlarge her power in America. The United States has never consciously or unconsciously come to an agreement with England for a division of power, except in so far as the Clayton-Bulwer Treaty was a proof that the United States recognized Great Britain as equal in certain American affairs. The country is no more indebted to Great Britain for not coercing us with her navy, than to Spain for not holding on to Louisiana, or to Germany for not planting a colony in South America. None of those powers wished to do those things. Foreign statesmen are not so clever and so farsighted as Professor Usher, and therefore have made none of the long-headed combinations which he would have made had he been Prime Minister of England, Chancellor of Germany, Premier of France, and Parliamentary leader of Italy. Nothing ever comes to pass in international affairs which is so smooth and easy and logical and complete and as regardless of hard facts as Usher's theory.

\section{PROMOTION OF PEACE}

Americans especially value their Doctrine for its southing effect upon the passions and turbulences of America : yet it has had little effect in preventing civil wars in either continent. Apparently the boundary wars in South Ameriça are about at an end, but the little Central American states still fight like cats in a basket. By its present application, the Doctrine of Peace has descended upon most of the West India islands and part of Central America. Civil wars and revolutions have for the time being ceased in Cuba, Porto Rico, Santo Domingo, Haiti, Panama, and Nicaragua, simply because the big stick has been put into operation there. Cuba has to be quiet; everybody there knows that any serious trouble will bring back the United States troops, and nobody ventures to predict that in that case they will ever leave. Porto Rico was easily gov- 
erned by the Spaniards and is reasonably prosperous under American control. The two negro republics have never been at rest since 1793 and are likely to require steady policing. Panama must be tranquil for the sake of the Canal; Nicaragua is held down by a small military force and the knowledge that there are thousands more where they came from. If the history of Latin America teaches anything, it is that there will be risings in most of those countries; and that something like a garrison will have to be placed in each of them, if order and peace are to be continued.

The same methods may perhaps be awaiting Mexico. In that case we should again face the difficulty which has been so troublesome with regard to the Philippines. None of the dependencies can expect to take part in the general affairs of the Union ; that is reserved for States. None of them can be trusted with local self-government like that of the former territorial governments of Dakota or Oregon. To retain unwilling subjects and deal out their government to them from Washington, is a denial of our own principles of freedom, which cannot fail to have a bad effect on our sense of liberty. Seventeen years ago there was not a community within the control of the United States (except the District of Columbia) which was not a State or in the way to become a State. Now there are eight such lands or groups.

We have peace in our borders and may be obliged to extend that blessing to Mexico, but it is a peace which brings with it a responsibility to every European government for anything that befalls their citizens in any of these regions. That is why Sir Edward Grey, the great English diplomat, in a public address in 1911, paid his respects to the Doctrine:

“ They knew that anything like war between the United States and the British Empire would be so violently opposed to the deepest sentiments and feelings of the people in both countries as to be unthinkable. ... In the United States they had no intention of disturbing existing

The Doc-

trine is Territorial. British possessions. They had a policy associated with the name of Monroe, the cardinal point of which was that no European or non-American nation should acquire fresh territory on the continent of America.

"If it be, as I think it must be, a postulate of any successful arbitration treaty of an extended kind that there should be no 
conflict or possibility of conflict between the national policies of the nations which are parties to it, this condition is assured as between us."

\section{PROMOTION OF COMMERCE}

The commercial motive has been sufficiently discussed at several points in the history of the Monroe Doctrine. Historians and critics are right in thinking that the economic motive, the desire to make money, - or at least to make more money, - is the final factor in many international rivalries and wars, where its influence is not distinctly seen. Every student of the question must judge for himself how far the United States has been guided consciously or unconsciously by the desire to expand trade and profits.

The weakness of the economic theory of history is that it leaves out of account an international fact which is common in the relations between individuals, namely, the willingness of most men to lose money and property in the desire to punish somebody else. Not one of the European nations engaged in the present war can make enough money gain in the next twenty-five years, out of any conquests or advantages that may result, to pay the losses and costs of its own fighting.

The people of this country are also much deflected from their usual principles, and perhaps from their real economic interests, by the glamour of colonies. The farther away colonies are, the livelier is the belief in the profits which they will furnish. Three hundred million East Indians, by a very small contribution from each one, may add to the wealth and prestige of Great Britain. Eight million Filipinos cannot by their trade or their wealth increase the per capita of production and savings for the American Empire. Indeed, all the dependencies and protectorates taken together are worth far less commercially to the United States than the one State of Pennsylvania.

One reason why the commercial advantage of these outliers is so slender is that the protectorate system does not bring the protected countries into close enough relations with the home countries. Every one of them is outside our customs boundary ; and judging from the experience of the Philippine Islands, which waited eleven years for that act of common sense and justice, the date is far off when the full protectorates will have the 
proper advantage of a commercial connection with the Union. There is no constitutional objection to admitting the products of Haiti and Nicaragua free of duty; but there is no reason to suppose that Congress will so vote. Meanwhile, each of the little protectorates has its own customs system, which must correspond with the judgment of Washington. The obligation of our government to the bondholders to turn over to them a percentage of the customs receipts makes it necessary that the duties should be low enough to be productive. In the long run, however, there will be a feeling in Congress that the people for whom we are doing so much, ought to give us more trade.

That brings back the old stumbling block in the way of reciprocity with Latin America. The principal products of all those lands are either foods or raw materials for manufactures, and the United States government has never accepted the theory of free raw materials. Protected interests prefer a duty on raw materials, and an extra compensating duty on the finished product. The United States has not adjusted itself to the English practice of drawing raw materials from colonies by very favorable duties, and paying for them in manufactures.

The American Doctrine has so far troubled itself little about those obstructions to commerce which are caused by awkward and oppressive methods of laying customs and other taxes. On paper the Pan-American Congresses have shown an interest in a uniform system of tariff administration - definitions, classification of goods, methods of establishing values, and so on. There have even been schemes for a general customs union, the difficulties of which are treated in an earlier chapter. The United States is in a position to earn the gratitude of the LatinAmericans by sharing in a general administrative system, in which there might be several different scales of duties, according to the preferences of the various countries. Tariff wars between groups of nations are likely to be a feature of the future world. Such groups in Eastern Asia, the Near East, Central Europe, and Western Europe may enact uniform systems of customs, shipping and transit laws, and may engage in tariff wars with each other. If the United States could form a combination with her near neighbors, and take all their products that we could use, it would strengthen the political ties and sense of common interest: but such a policy has been no part of the American Doctrine, is out of accord with the financial 
and commercial policy of Congress, and is not likely to be taken into the Doctrine of the Future.

\section{ENFORCEMENT OF THE RESPONSIBILITY OF LATIN AMERICA}

The original idea of John Quincy Adams, if not of Monroe, was to relieve othe American States from a part of the necessity for defending themselves. That policy was unpopular and, till the French came to Mexico, was never put in play. It has now been revived by the adoption in the last ten years of the method of the "Big Stick." That utensil is easy to manipulate in small communities; but in the case of Mexico it looks as though nothing but a thundering big stick could do the business. Yet Mexico is more likely to call forth the use of the American army and navy than any other part of America. With no country are the causes of trouble so numerous. The international boundary is long and disquieted; heavy American capital is engaged in the Republic and calls for protection. So far as the Canal is concerned, Mexico is "On the Road to Mandalay."

Unless a speedy and thoroughgoing repentance comes about, there seems no other way in the long run than for the United States to step in and establish order, rather than see some European power or combination accomplish that work. In the tension of public feeling arising out of the European war of 1914, the landing of a German army in Mexico at any time in the near future would be as well calculated to bring peace to America as a descent of Turks on the Suez Canal would bring peace to the Orient.

As for the smaller powers, they have kicked and squirmed under the weight of Uncle Sam less than might have been expected. Our action in the protectorates puts the Administration in a position to enforce a few salutary principles as to contract claims and public debts. To the Drago Doctrine the United States is already committed, both by our action in the Hague Convention in 1907, and by the limitations on the occupation of Venezuela in 1902. The Calvo Doctrine, - that foreign governments shall not interest themselves in collecting private claims, - rests on the same logical foundation as the American common law doctrine that no man except a soldier or sailor can make a legal contract for personal services, specific 
performance of which can be enforced by a suit. The moment a man agrees that another man shall in the future control the movement of his muscles or his pen or voice, he ceases to be free. So the borrower who makes a contract or borrows money with the understanding that his creditor's government will come down upon his government if the money is not paid, has contracted to do what a foreign government directs; he is no longer a free agent. Calvo is right in his belief that the world would get on better if lenders to persons outside their own land must depend upon the ordinary courts of the debtor country for their remedy.

Unfortunately the world has not started in on that basis, and hundreds of millions of dollars have been lent, which can never be collected without the aid of the European diplomats. If the American countries need capital, they cannot get it unless they can give some assurance that previous lendings are safe. There is therefore no way out of European money difficulties except to depend upon the express promise of the United States to be a policeman! "Weak states that can pay and won't pay must be made to pay" - that is practically the doctrine.

This brings all such Latin states under the tutelage of their strongest neighbor. Europe so far has been willing to accept the results without too deeply examining the process. As matters are now moving, the United States guarantees that the revenues of the protected states shall be carefully collected and administered, and also that they shall be sufficient to safeguard the public debt. If insurgents and rebels and revolutionists and popular uprisings in Haiti, for instance, decrease the purchasing power of the inhabitants and therefore cut down the customs receipts, such movements must be put down. The United States cannot be responsible for the payment of an old debt and at the same time allow a new one to be incurred.

\section{THE FUTURE DOCTRINE MUST BE SIMPLE}

A multitude of quotations in this volume from public men, especially Presidents and Secretaries of State, show the numerous changes in the Doctrine which obscure its meaning. Cleveland, Roosevelt, and Wilson have all tried to make the Doctrine clear by using many words. What we now need is a statement 
in a few words which may in some way be put before the world as the controlling principle under which future events will be regulated as they arise. Monroe included at least four different propositions in his one doctrine. Is there any one brief form of statement which will carry the meaning, avoid the pitfalls, and accomplish the results.

As a phrase of two words, nothing better has ever been coined than Evarts' "Paramount Interest", because it puts into relief both sides of the American Doctrine: first, it springs out of "interest"; secondly, it is defended by a "paramount" interest. Paramount to whom? Manifestly to all other powers, European, African, Asian, or Australian. In practice, also paramount to the Latin-American states, whose standing grievance is that they are counted inferior in the calculations of the United States.

This ground is over-covered by such phrases as Olney's "sovereignty", "fiat" and all the rest. Those words were intended to be offensive to England, but they are doubly offensive to Latin-Americans, for they are a denial of their right to exist, except so far as the United States may permit. These violent and exaggerated forms of statement weaken the Doctrine because they assert a degree of authority and of power which the United States does not possess and could not exercise except through a general American war.

In its simplest form the Future Doctrine should include first of all, the interest of the United States, for her own sake, against Europe's obtaining new footholds in America. Some people still seem to think that our interest was created by the say-so of Monroe or Fish or Blaine or Roosevelt. On the contrary that interest exists in the nature of things, would have existed without any public Doctrine, and would continue to exist even if the United States should by statute declare the Monroe Doctrine to be abrogated.

The next step is to define the reason for making that interest felt, which brings into relief the altruistic side, the honest republican desire that our near neighbors may be given the chance to practise republican government; and the mutual advantage to both parties if they can act in harmony upon this matter.

The next point would naturally be one which appears in many forms of the doctrine, namely, that it is not the desire of the United States to annex any more territory south of its present 
boundaries. That point can no longer be safely included in any definition of the American Doctrine because we have never recognized any limitation on that subject in the Monroe Doctrine; and because we are now, from year to year, picking up territory which is not likely ever to see independence again, - unless the United States is worsted in a great war.

At this stage in previous efforts to define the old forms of the American Doctrine enouncers have usually planted themselves on the principle of the Two Spheres. The attempts to look upon the round world through a pair of spectacles in which the two glasses have different focuses was never successful and is now entirely out of date. The United States is a Canal Power, a Pacific Power, and an Asiatic Power. We are no longer entitled to special consideration on the ground that we take no part in the affairs of the other hemisphere - the nation does and must take a part.

The future Doctrine should make no pretense to be "international law" or "public law" or "inter-American law." It is not law at all, except in the sense of the physical sciences; the investigator notices that certain things happen so many times that he infers that all these happenings have a common cause. The American Doctrine is not a "law" for the people of the United States because none of them is required as an individual to believe and obey. It is no law for foreign nations but simply a warning of the disagreeable things that may happen to them if they ignore it, like a notice of "No trespass" put on the fence of a disputed field. It is certainly not law for the Latin American states, who did not make it and resent every part of it that sets limits and bounds upon what they might otherwise do as sovereign nations.

The future Doctrine will not even be a "doctrine" in the sense that is usually applied to the term, namely, a generalization which explains the past and provides in its categories for things that have not yet happened. Nor will it be a doctrine in the sense of a permanent state policy: for a doctrine which changes from decade to decade has already ceased to be anything at the end of the first ten years. The popular notion that the United States has, ever since 1823, followed an unwavering uniform policy is a delusion which is easily refuted by the course of history. The American Doctrine is not even a single large principle; it is sub-divided into various more or 
less connected ideas, which vary from presidential administration to presidential administration and are sometimes contrary with themselves. Witness the contrast between the principle that foreign nations must not annex American territory and the equally well established principle that the United States may annex what she pleases.

\section{THE AUTHOR'S DOCTRINE OF PERMANENT INTEREST}

Any one who tries to express in brief his idea of what the American Doctrine rightfully is, must first face the facts of the world as they are. He must take account of the number of American states, and the variety of their size, civilization, and capacity for government. On the other side he must picture to himself the world at large, with its ambition for naval stations and colonies. In the foreground he must place the United States of America, with her natural desire to enlarge in area, in spirit, and in influence upon the world. The history of American relations must also be examined to see, not so much what our government has professed, as what it has attempted; and among those attempts, what it has really put into action.

From the point of view of actuality, basing conclusions on the world, and then on the Western Hemisphere and especially on the nation of the United States of America as it is, the author suggests the following statement of the American Doctrine, not as a reflection of his own views, but as a condensed statement of what he believes to be the body of principles held by the American people.

The people of the United States of America believe that the safety and happiness of mankind depends upon the opportunity of

Self-government in

America. each nation to govern itself; and that most nations which have the opportunity to choose will desire the democratic form, which is the accepted principle of every one of the twenty-one independent American states. Attempts from without, to substitute monarchical forms are hostile to the United States.

Territorial Completeness of the Two Americas.
The two continents of North and South America have long been completely occupied by native governments except for Canada and for some other small European colonies which have existed a hun- 
dred years and which have shown no hostility to their neighbors. There is therefore no opportunity for foreign nations to alter the map of America, though the American powers may combine or separate, and the United States is free to annex territory according to her judgment.

Among these allowable territorial changes are protectorates by the United States over those formerly independent islands and small land states which are nearest to us. These are necessary to protect the Canal route, or to safeguard American capital or to avoid giving to European powers an excuse to intervene and land military

Protectorates of the United

States. forces.

For the above reasons the United States undertakes to prevent certain causes of trouble between Latin-American and European and Asiatic states. This leaves to such powers no good reason for intervening in America except the defense of national honor or interest from violence.

Protection against Europe. In such cases the United States decides whether there is a just reason for war. Against any effort to build up colonies our government will protest, and in the last resort will use military and naval force to ward off what would otherwise become a danger to the United States.

For this purpose the United States will, as occasion serves, consult the strongest and stablest Latin-American states, without entering into any arrangement by which the decisions of the United States could be overruled by votes or combinations of other powers.

Coöperation with Latin America.

These principles depend upon the permanent interest of the United States in preventing European nations from altering the controlling status of the United States by conquest, by colonization, by acquiring naval stations, or by

Permanent intervening in behalf of contracts, claims, or debts.

Having by repeated statement and acts affirmed these principles, the United States holds that the rest of the world is aware of them and must accept them as the basis of their relations with America.

Notice to

the

World.

"Permanent Interest" might be well used as the briefest phrase which describes the Doctrine of the Future. It is free from the objection of "Paramount Interest", which seems to claim a supremacy in America that the United States is not called upon to assert as an official principle. Permanent Interest is not based upon the name or reputation of any one statesman. Permanent Interest is opposed to all forces 
and influences which might endanger other extra-American possessions of the United States, such as Hawaii and the Philippines and Liberia. Permanent Interest is as good against Asia as against Europe. Permanent Interest does not exclude the side of sympathy and neighborly feeling; it is a permanent interest of the United States to sympathize with our neighbors' troubles, for that is one way to avoid quarrels with them. Permanent Interest adapts itself to all changes of conditions, while leaving the kernel of the doctrine whole. Permanent Interest is the same in principle as the interest which external powers feel in their hemispheres and spheres of influence. Permanent Interest is no discovery or novelty : it is simply an attempt to state as the ruling principle of our government the considerations which actually rule that government. 


\section{Chapter XXIII}

\section{PEACEFUL MAINTENANCE OF THE DOCTRINE OF PERMANENT INTEREST}

THE MONROE DOCTRINE A STATE OF MIND

ONE of the most serious faults of American statesmen and the American people has been their habit of looking upon the Monroe Doctrine as a sacred principle which needs to be stated, but not to be executed. It seems to have the weight of the Ten Commandments, which are not questioned or limited or construed, but obeyed. In some ways this trust in a paper Monroe Doctrine has been justified, because it has usually been framed in words and not deeds. The powerful sentences of James Monroe actually gave pause to European governments. Seward's despatches with their rising confidence that the French could not wish to remain in Mexico, compelled Napoleon to give the order for the withdrawal of his troops. Olney's rhetoric was more cogent than all the logic of Lord Salisbury. The motto for the popular idea of the Doctrine of Permanent Interest might well be "What the United States says, goes."

What has really made both the Monroe Doctrine and the Doctrine of Permanent Interest respected, has not been this state of mind of those who have expressed the will and purpose of the United States, but the ideas of foreign statesmen who were disposed to set themselves against such a will and purpose. The effect of the Monroe Doctrine, like that of many formal laws and ordinances, has been to lead to a general belief that if it were not observed something disagreeable would happen. This idea has been allowed to hold sway in Europe because Europe had other things to think about. American affairs and the possibility of securing American territory have played rather a small part in the combinations of Europe during the last hundred years. 
The commercial conditions which brought the West Indies to the fore have long since changed. The semi-tropical products in which they had once almost a monopoly are now raised in - many other parts of the world. Cane sugar has to compete with beet sugar on the continent of Europe, and even in the United States. Brazilian coffee must maintain its market against the Orient. Rubber about equal to the Brazilian article is raised in Ceylon. Except for the four large West India Islands, - all but one of which are now under the supremacy of the United States, - the parts of America best worth owning have been the most defensible. Germany is superior to Brazil in military and naval strength; but the Germans who could be landed in Brazil, for the purpose of invading it, might, be inferior in strength to the defenders.

The psychology of Europe has lent itself readily to the belief that there is nothing in America which up to this time has seemed worth while to possess, against the resistance of the local states, against the threats of the United States, and against the supposed conviction of Europe that it was unseemly to conquer and annex the territory of weak states. Great Britain particularly has come to the conclusion that it is not worth while to keep up an opposition to the known wishes of the United States. "You Americans are a hard people to run away from," said a distinguished English statesman; by which he meant that whenever a controversy with this country arose it was difficult to grant it easily and gracefully without being thought weak.

The present hypnotic effect of the Monroe Doctrine on Europe may die out in either of two ways. Foreign nations may cease to believe that the United States will defend her Doctrine, if the issue is squarely raised; or, the Americans may themselves show that they are not willing to endure the dangers and sacrifices which maintenance of a Doctrine of Permanent Interest is likely to bring. The effect of written statements of our position is about worn out. The two questions which the world now asks are: does the United States mean that America shall be for the Americans? If so, will the United States back up that decision with men, guns, and ships? 


\section{THE NATIONAL DETERMINATION}

Up to the Spanish War of 1898 this country stood at the parting of the ways: it was still possible then to withdraw quietly from responsibility for any other nation on earth, or any territory outside our own boundaries. This was very nearly Grover Cleveland's policy during his first administration, and has been urged in 1898 and since by strong writers and active propagandas. The nation deliberately chose the other road. It stood by its ancient belief that misfortunes to other American powers were indirectly misfortunes to the United States of America. Specifically, it listened to the cry of the Cubans for sympathy and aid in 1898. Porto Rico, Guam, and the Philippines were unexpected prizes of war; but McKinley justly interpreted the public sentiment of the time that they must be kept. Notwithstanding the resistance of the Anti-Imperialists, they were added on varying terms to the American Empire.

Roosevelt made possible a United States Canal across Panama ; but if he had not secured that route by rough-and-ready methods, the sentiment of the country would have pushed the Administration to the Nicaragua route. When our government once owned the Canal, the people were willing to accept whatever form of Doctrine might be necessary to protect that route. The action of the Administration on Venezuela and the Drago Doctrine seemed reasonable to most thinking Americans. The necessary outcome of that action in the protectorate of Santo Domingo was unpopular in the Senate because it seemed to the Senators an infraction of their power over treaties; when they ratified the later treaty, they accepted the pólicy, as either a good thing or a necessary evil.

The subsequent territorial progress of the United States in Central America and the West Indies has aroused very little alarm, perhaps because people do not realize how fast and how far it goes. The country in general supported President Taft and President Wilson in their unwillingness to intervene in Mexico; but if they had followed the same active policy of intervention there that they followed in Nicaragua, apparently they would have had the support of both houses of Congress and of a majority of voters.

Voices have been plentiful to protest against these methods and their consequent responsibilities. No subject has been 
more discussed; and the evidence all goes to show that the American people, some with joy and some with regret, consider themselves bound by ties both of interest and honor, to maintain the permanent interest of the United States in American questions, in the teeth of European or Asiatic interference.

With that happy-go-lucky belief in their own star which is characteristic of Americans, the United States has never worked out any definite system for maintaining the Doctrine of Permanent Interest if it should become necessary. Now that the Doctrine is contested both by its opponents and by its beneficiaries, and the spirit of the world is changing on questions of conquest and colonization, the United States must either withdraw her doctrine or defend it. In what manner defend it?

As Admiral Chadwick says of it:

"The Monroe Doctrine is not in any of its meanings or forms a part of international law. It is but a pronouncement of a policy and as such it may be ignored by any power which chooses to ignore it. It has life and being only as long as the United States is ready to back such policy by force."

\section{FORCE OF THE EXAMPLE OF THE UNITED STATES}

The Doctrine of Permanent Interest is not automatic; it cannot even sustain itself. What are the pillars upon which it must rest if it is to endure? Some of these supports are moral, some legal, some international, some military. The guarantees and lack of guarantees will both appear, if we take up in succession the various agencies which may be invoked to keep this structure secure from dangers within and without.

The mildest influence in America for virtue, peace, and safety is precept. So far as our neighbors are concerned, they have always been expected to take whatever kind of doctrine was dished out for them, because it was intended for their good. Our State Department has read many moral lessons to refractory American governments. A considerable part of the Doctrine of Permanent Interest - all of it that is disliked by the Latin-Americans - would disappear, if they would "only be good"; and the obvious way to avoid the difficulties which bring about trouble with Europe would be to take the United States of America as a model. The theory of our Government is one of individual rights, of freedom of movement, career, and oppor- 
tunity, of unrestricted public discussion, of a right to vote for officials and even for measures. In general these are the official methods and purposes of all the twenty other American republics. Why not avoid trouble with Europe by their imitating the United States? We constantly complain of the LatinAmericans because they approach their government from the point of view of one-man power, or in the states that are farthest developed, of the power of a small aristocracy. Somehow, our democratic example has not had the desired effect.

The difficulty is that the Latin-Americans make bold to think of the United States in other terms than admiration. They have an unpardonable fondness for pointing out dents in our shining armor. They tell us that their officially recognized dictators are no worse than our unofficial bosses; that an aristocracy of coffee-planters is just as reasonable as an aristocracy of railroad kings and manufacturers and bankers. When we tell our brethren that they must give up the horrible cruelties practised by military despots, and insist that the killing of unarmed prisoners is inhuman, they ask why we fail to stop the abominations of our penitentiaries, and why we permit helpless prisoners to be taken out of jail, and murdered by men who appear to be backed by the public sentiment of their neighborhood. When our newspapers print accounts of the horrors of a Mexican battle, the Latin-American newspapers print accounts of riots, lynchings, and open defiance of courts and law.

If a band of men hold up and rob a train in Guatemala, they are "desperate brigands", who reveal the weakness of government and the insecurity of rights and property. When a similar band of men hold up a train in Arizona or Illinois they are only "road agents", who shoot nobody unless he resists. Only one legislature in the Union has thought it worth while to create a State Constabulary which can put down those gentry. When a few rich Latin-American land-owners and military chieftains combine to get possession of the national capital and loot the treasury, they are in a "conspiracy" which deserves to be punished by intervention from the United States. A similar combination of a few rich men with ward chieftains, who take possession of an American city government and loot it, is a "political ring", which is a subject for jocose cartoons. It is true that the United States is on the whole an orderly part of the world, governed by good intentions, if not with efficiency, while Mexico 
and Nicaragua are volcanic centers of the human passions. However, the Peruvian miner and the Argentine ranchman think they are as competent to make good government as the Yankees; they are confident that they approach as near to popular government as some of the communities of the United States. The form of federal government has been widespread in Latin America; and perhaps in Brazil and the Argentine there are such things as States and cities that have something like home rule. Nowhere else in Latin America is there a body of units of government which can be compared in local consciousness with the States and cities of our Union.

\section{BENEVOLENT LEADERSHIP BY THE UNITED STATES}

May not the Latin-Americans be led in a Monrovian path of virtue by the more direct and formal leadership of the United States, acting as primus inter pares? This idea has already been examined in the discussion of Latin-American union. It is an old notion which might work well if it could only work at all. Did not Athens hold the hegemony of the Delian league? Was not the Province of Holland the inspirer and leader of the Dutch United Netherlands? Has not Prussia been the mentor of the German Empire? Why should not the United States point the way of happiness and greatness to all America?

This conception was clearly in the mind of John Quincy Adams at the time of the Panama Congress, but he had not the backing of his own country, because leadership implied the responsibility to defend as well as to advise. The Delian, Dutch, and German confederations were united by strong pólitical bonds which gave to the leading states an almost unquestioned right of offering counsels which must be followed. If benevolent leadership means only good advice from time to time, it is too weak to be called a tie; if it means that the big power is to make decisions for the small powers, then the small powers practically disappear as sovereign nations. Polk, the ablest diplomat of his time, turned our neighbors' minds once for all away from any such leadership when he undertook annexation of Latin-American territory. We must accept it as a cogent fact that the Latin-Americans do not believe that the Yankees are so much wiser and far-sighted than their neighbors that they are capable of ruling both themselves and others. 
Many Presidents and Secretaries of State have sought to lead Latin America into the relation of little sisters to a big brother, and every such attempt has come to grief. Buchanan's policy of pacifying Mexico and Central America by annexations drew on him the scorn of his political enemies. Blaine's well-meant and statesmanlike effort to build up an international conscience among Latin-American powers was a bad failure, partly because of the weakness of his agents, and partly because he was himself too ardent for the task. Olney's lurid statements of the glory, power, and supreme authority of the United States accomplished the immediate object of causing Great Britain to let go of Venezuela, but left permanent distrust in LatinAmerican minds. Knox's and Bryan's Dollar Diplomacy has secured some dollars and fortified the Latin-American discontent. Whatever other solution there may be, no change of circumstances can make it possible for the United States to put herself forward as a leading power which shall actually lead, except to military music.

\section{INTER-AMERICAN LAW}

Would a still stronger form of political attraction keep the Latin-American States in their orbits? Could there be, perhaps by the medium of a series of interlocking treaties, a general understanding of what the United States desires by her Doctrine of Permanent Interest, and what the other states accept? That is, could there be a pact intended to cover the relations necessary to insure the independence of the American states? In that direction, the Pan-American Congresses have worked without much result, perhaps because they undertook too much. The main difficulty with such a pact is that it would be worthless unless it included a square promise by the United States that she would call out horse, foot, and gun-boats, if necessary, for the defense at least of "good states" which had given no real offense. That promise the United States has never been willing to give, although the time for shyness on that point has long gone by. Our theory of the American Doctrine of Permanent Interest has been that we are to tell the rest of the world what they must do, without clearly indicating what we intend to do.

"Inter-American Law" is difficult, although not impossible, because there are two sources of the law of America - the Roman 
and the English Common laws. The field which most needs modification is the law of obligation - a clear understanding of what shall be recognized as collectible debts, and a simplification of the methods of collection through the courts. Along with this must be decided the crucial question of the status of aliens. The United States in practice makes the same point as that insisted upon by Venezuela and other Latin-American states, viz. that the alien has no privileges superior to those of the citizen and that his privileges may be much less. For instance, in many of the States of the Union an alien cannot hold real estate. Some of the Latin-American states would like to go farther and insist that the alien must accept the status of the citizen, whether he seeks naturalization or not. The real issue here is the question whether the Latin-American communities are imperfect states, like Turkey or China, in which the laws ought not to apply to the superior foreigner.

Philip M. Brown, formerly minister to Honduras, is confident that the law of America can be greatly unified.

"While no one nation should constitute itself the sole judge of its rights, no nation, on the other hand, should be permitted

Interna-

tional

Codes. to escape the fulfillment of its just obligations. The determination of these rights and obligations is properly a function of law. We should, for example, have an agreement of the nations of this hemisphere, if not of the whole world, as to the precise rights of international creditors; as to the circumstances justifying a nation to go into bankruptcy; as to the legal methods permissible for the collection of debts; as to the rights of foreigners to reparation for torts; as to the rights of foreigners to damages for wrongs committed in times of civil disturbance; and many other such questions that give rise to diplomatic friction, reprisals and even war.

"If the other nations of the world, owing to political problems yet unsolved, are unable to undertake yet this great task of creating the law which must eventually supplant war, we in this hemisphere have no excuse if we do not whole-heartedly direct our energies in this direction."

The main difficulty in any method of lessening the friction in America by legal agreements is that the United States has not confidence that they will be carried out by revolutionary and dictatorial governments; nor that the Latin-American courts can be depended upon to give such justice to the alien as could 
be expected from the courts of the United States. Possibly there might be a gain from drawing up a general American document, defining the cases in which all the American powers of consequence would take steps to prevent their neighbors from acts which might justly offend Europe.

We must not forget that so far as the Doctrine of Permanent Interest has yet gone, it includes no pledge to protect any American power which backs up an insult to the flag, the diplomatic representative, or the merchant or naval vessels of a European power. "The American Doctrine does not, therefore, include a large class of acts which at any time may rouse Europe to call for intervention, or which may lead to war. If Chile, for example, should deliberately sink an English ship and England sent a fleet to bombard Valparaiso, the United States would be under no obligation to defend Chile or even to protest. Whatever action was taken by Washington, - and some action would surely be taken, - would lie outside of the Doctrine.

\section{PAN-AMERICAN ORGANIZATION}

The difficulties in the way of a mild union become still stronger when the attempt is made to create a closely knit American union. If the Latin-Americans cannot combine into any political organization for their own purposes, how can they be expected to combine with each other and at the same time with the United States? Doubtless the world nowadays makes too much of race unions and race antagonisms. If Italians, Frenchmen, Slavs, Germans, American-Indians, and Negroes can work together in our federal union, Latins and Teutons might sufficiently agree to form an international union.

John Barrett, director-general of the Pan-American Union, who has been minister to several Latin-American powers, is entirely confident on that subject. He puts it as follows:

" I believe the time is coming when there may be evolved from the Monroe Doctrine itself as a principle and phrase, and thereupon substituted for the Monroe Doctrine as a principle and phrase, the principle and phrase of a 'Pan-American policy.' . . .

"The Pan-American policy would adopt, absorb

Independence within an American Union. and enlarge the Monroe Doctrine as an original policy of the United States into a greater and all-American policy, where each nation 
would have the same rights of attitude, the same dignity of position and the same sense of independence as the United States now has. . . . By the substitution of 'Pan-Americanism' for 'Monroe' - thus including all the American nations as sponsors - and by the substitution of ' policy' for ' doctrine' and thus removing the hard, unyielding, dictatorial and didactic suggestions of the words 'Monroe Doctrine', about which every Latin American is a little sensitive, a long step will be taken towards a new era of PanAmerican comity and Pan-American confidence. . . .

"Then we will have achieved, in my opinion, that ideal, unselfish, fraternal relationship of the American governments and peoples which will give a new worth and a permanent, acceptable significance to Pan-American relationship, Pan-American accord, and the status of the Pan-American Union."

Mr. Barrett is a strong authority because he is the executive officer of the only Pan-American organization which at present exists. This was organized first as a library and center of information, then as the Bureau of American Republics, and was stimulated by the Pan-American Congress of Rio, in 1906. Since 1910 it has had the formal name of the Pan-American Union. It is housed in a building provided by Andrew Carnegie in Washington. All the American powers contribute to its support, and are entitled to its results. It began to publish bulletins in 1891, which during the last dozen years have been published and distributed as public documents. The Bureau has done much to interest itself in trade questions.

The most courageous apostle of Pan-Americanism is Usher, whose ingenious views on other questions have been widely circulated. In his book on Pan-Americanism, he sketches the "prerequisites for the erection or creation of a Pan-American confederation or union." He thinks it must be "a confederation of sovereign states, with a common executive and legislature." The states are to have graduated votes, and "schedules of issues might be prepared ... graduated according to the importance of the subject." Foreign affairs must be carried on by the confederation "with either the abandonment of the Monroe Doctrine, or its assumption by the confederation." To carry out this scheme, Usher thinks it "eminently desirable" that there should be "free trade within the confederation and a uniform currency." The negro problem is to be solved by "the granting of social equality to South Americans by the 
citizens of the United States." Having thus led Israel into the promised land, our Moses then announces that "We have no actual evidence of a desire on the part of the United States to make it real." He is therefore perfectly safe in coming to the eventual conclusion that we are "dealing with the possible creation of something which never existed and which does not now exist." Pan-Americanism is not so inept as all this : but it is certainly not a reliable method of maintaining the Doctrine of Permanent Interest.

\section{LIMITED AMERICAN ORGANIZATION}

To the Latin-American mind the only likely Pan-Americanism is the dreaded union brought about by the United States absorbing enough of her neighbors to make one predominant Saxon-Latin-American State. A lesser form of combination has been brought to the front by the efforts of the A B C Powers in 1913, and again in 1915, to aid in the salvation of Mexico, which have been elsewhere discussed. Charles M. Sherrill, recently minister to the Argentine, sees a possibility of success in the coöperation of a few self-chosen strong powers :

"Suppose affairs should take so serious a turn in Mexico that, either to forestall an armed intervention there by some European power seeking to defend its citizens or else perform like service for some citizens of our own hemisphere, it finally becomes necessary under the terms of the Mon-

Joint American Responsibility. roe Doctrine that the United States intervene, I would suggest that we invite Argentina or Brazil or some other American country to join with us. . . . It would entirely remove any idea among our South American neighbors that our purpose was land grabbing, because a man does not invite his neighbors to accompany him on an errand intended to benefit him alone. Secondly, .... it would free our government from the persistent importunities of individuals and corporations urging our sole intervention to benefit their own pockets, but who would not favor a joint intervention by us along with other powers. Furthermore it would be the best and most convincing form of invitation to Latin America to participate equally with us in the responsibilities and development of the Monroe Doctrine. The great Doctrine would at once become continental, and cease to be unilateral, which is to-day its one great defect." 
There is vitality in this idea, because whatever the United States and the A B C Powers may agree upon, can by their joint physical power be put through. If Mexico ever returns to sanity, that nation may become one of the selected circle. Peru, Colombia, Uruguay, and possibly others may eventually also be admitted. Such a working union, defined by a treaty or resting upon a common understanding, could do much to simplify the Doctrine of Permanent Interest, because part of the duty of keeping in order the irrepressible violent states might then be performed by other members of the combine than the United States. Why might not a few hundred Brazilian troops be called in to keep order in Haiti, and if necessary to collect the customs and pay the creditors?

This plan has the wholesome virtue of recognizing things as they are, of making distinctions between the real Latin-American states and the pseudo states. It is, however, a system of legalizing the internal wars which have been a curse to Latin America. It does nothing to settle the critical question, Will the United States accept unwelcome advice from the A B C Powers, and from other powers as they come up to the required political standard? If so, there may be a real combination; if, on the contrary, nothing unpalatable is ever to be granted by the United States, the arrangement would be only a delusion.

An internal social question, which on its face has little relation to diplomacy, comes in at this point. Many of the people and some of the military and civil leaders in several Latin-American states, have Indian or Negro blood. The Indians would probably be hospitably received in conferences with the United states, for non-tribal Indians are voters in this country, and two of the federal senators have Indian blood. A mulatto alliance would terribly complicate Washington society. To the minds of most people living south of Mason and Dixon's line, it is entirely out of the question for the Government of the United States to make any alliances or agreements or understandings which are based on personal and national equality with countries in which there is a strong infusion of African blood. 


\section{INTERNATIONAL ARBITRATION}

One way of avoiding the issue of force is to build up a machinery for settling all difficulties, including those which may arise out of the Monroe Doctrine; and great efforts have been making during the last twenty years to secure a world arbitration. The two methods which have been put into operation are, first, a system of interlocking, by which every nation may be so tied up by individual treaties with many other nations that almost any quarrel can be held up till there is time for peaceful adjustment. President Taft and President Wilson have both pushed this method far, especially with the Latin-Americans. The first difficulty is that we have no effective treaty of that kind with the nations that are most likely to descend on America. The second is that these treaties are limited in duration. The third is a limitation originally pressed by the Senate to the effect that questions involving the honor and territory of the United States are not to be included.

Such a system, if it does not break down on trial, is a weak protection against sudden international cyclones. It prevents nations from going to war over a single incident or insult; necessarily it has very small influence over against big questions of national policy and greatness, such as the Monroe Doctrine. From the standpoint of the intense Monroeists any interference in America is not only contrary to national influence but is a direct affront against the United States : the only way to adjust it is for the foreign nation to recall its fleets and armies. Arbitration is in the way.

The second method is by a group of general arbitration treaties and agreements, to which all nations shall give their adhesion. This was the purpose of the two Hague Conferences. Bitter experience has shown that it does not stop wars in general. Since the first Hague Conference of 1899 the world has witnessed the Boer War, Russian-Japanese War, the Mexican Civil War, two Balkan Wars and the fearful War of 1914, in which eleven European nations are engaged. In not one single instance was the war prevented or delayed by an appeal to The Hague. No matter what promises are made beforehand, no matter how convenient the machinery for settling questions, nations which feel that their fundamental interests are endangered will go to war; or if peaceably inclined will be forced to a defensive 
war. The Doctrine of Permanent Interest is furthermore declared by the second Hague Conference to be outside the régime of the Hague arbitral machinery; which does not mean that European powers recognize the Monroe Doctrine, but rather that they do not consider it a part of international law.

All methods of arbitration stumble over the same rock of offense. The theory of general arbitration rests upon the fiction that the boundaries of the whole world are now adjusted and that the subdivision of world power is permanent. In fact, the present combinations and distribution of peoples are not in accord with their political arrangements in Europe, Africa, or Asia. The United States insists that a state of equilibrium has been reached in North and South America and yet, in the sight of the world, is from year to year enlarging her own power by taking possession of small neighboring states. So long as the Canal is held to be "part of our coast line" the boundaries between the North American powers are not yet fixed: to arbitrate the Monroe Doctrine would be like trying to arbitrate the ownership of the Dardanelles or the mouth of the Rhine or the possession of Tsin Tau by the Japanese. Turkey, Belgium, and China would welcome arbitration by an impartial tribunal if such could be found ; Russia, Germany, and Japan will never arbitrate. So the question whether the United States ought to prevent European settlements in America is outside of arbitration, because it pertains to future defense, world power and the place of the United States among nations. 


\section{Chapter XXIV}

\section{MILITARY MAINTENANCE OF THE DOCTRINE}

\section{AMERICAN BELIEF IN PEACE}

The theory, practice, and spirit of the Monroe Doctrine and all its successors has been that it is a means of avoiding war of all kinds - war between Latin-American states by the example and precept of the United States, which ought to induce them to avoid unnatural quarrels; war between the European powers and our neighbors, by preventing them from giving encouragement to aggressions; above all, war between the United States and non-American powers, by eliminating the dangers arising from boundary and other neighborhood questions. Hence statesmen and writers have been in the habit for many years of thinking that because the Doctrine's aims are peace, they can reach that end wholly by peaceful methods.

The United States has not been alone in believing that large principles of state policy may be carried out by pourparlers, by despatches, by understandings, by treaties and by arbitration. The whole trend of the modern science of international law has been to prevent quarrels, first, by laying down in advance rules accepted by both parties to a controversy; secondly, by providing means of accommodating differences either by a special arbitration or by an arbitral system; thirdly, by striving with much success to create the presumption that difficulties that seem insuperable may be settled, if both parties sincerely desire to avoid war.

The position of the United States has been especially firm in the direction of peace. It speaks well for the candor, skill, and humanity of American statesmen that in the last hundred years, while the storms of battle have beaten upon all the rest 
of the world, the United States has had but one war with a European power, and that so brief and so small in its dimensions that it did not disturb the placid current of internal affairs. Of late years, this spirit of peace has been much promoted by formal organizations. Besides several societies, there are now three wealthy foundations which aim to spread the cause of peace throughout the world and particularly to save our own country from wars and rumors of wars by showing that they are not necessary to reach the legitimate ambitions of our country.

In literature war plays a lively part. It $\cdot$ is not an accident that the favorite modern hymn is "Onward Christian Soldiers." Nevertheless, the trend of nineteenth-century thought in the United States has been in the direction of peace. Charles Sumner, who was anything but a mild spirit, and who once came near bringing his country into a needless war with Great Britain, was the first nationally known apostle of peace. His quotation of "Peace hath her victories" was in itself an argument. The efforts of Presidents and Secretaries of State to settle outstanding quarrels by agreement or arbitration have met with public approval. Mr. Bryan is proud of his thirty arbitration treaties.

With two rather serious reservations we have always felt a spirit of peace toward our near neighbors. The Mexican war was a backward step; but, so far, no other Latin-American state has been deprived of territory by the United States, except Colombia. The recent aggressions of the United States have affected the territory of the protectorates, but haye there taken the alluring form of aid and sympathy to distressed peoples who could not organize their little governments even for their own protection. The presumption of the United States, of her people, of Congress and of the Administration, is that America should be at external peace and that peaceful methods are adequate. A significant proof of this pacific disposition is that the disturbances just south of our borders, with considerable destruction of American property and lives, have not as yet diverted the United States from peaceful neutrality toward Mexico. Considering the four years of carnage and senseless destruction, and the losses of American property and lives, the Administration has shown a forbearance which ought to reassure our neighbors. 


\section{AMERICAN BELIEF IN OURSELVES}

A strong reason for national confidence in this preference for peaceful ways is that with few exceptions the United States has obtained what she wanted without war; the conclusion is irresistible that this, among all nations of the earth, has a peculiar right to be heard when she states a demand. The late Justin Winsor remarked that in all our controversies with Great Britain, the United States had the better in the settlement. He thought that one reason was the number of issues which had been adjusted by treaties made at Washington, in which he believed the Secretaries of State to be superior diplomats to the Ashburtons and De Greys and Pauncefotes, on the other side of the table. A stronger reason is that nearly all those controversies arose out of questions in which the interest of the United States was visibly greater than that of England. Our' claim to the Columbia River and to indemnity for the Alabama captures was in every way fiercer and more determined than England's counterclaim.

"There is a special Providence for little children and the United States," said a German sage. It must be owned that some things which we fancy are due to our own sagacity and foresight are simply part of the march of history in which we are beneficiaries rather than agents. Nobody in the world guessed that gold would be discovered in California a few days after the Treaty of 1848 was signed, by which California was formally ceded. Nobody in America, Europe, or Asia realized the economic and strategic value of Alaska, when Russia offered it to the United States in 1867. Nobody perceived when Lewis and Clark were struggling across the backbone of the continent that they would be followed by iron roads which would bind the Atlantic and the Pacific together. Notwithstanding the surface film of oil on certain watercourses, nobody guessed till recently the prodigious wealth and width of the oil fields of Texas and California. We have drawn unlimited checks on the Bank of the Almighty and when they have been cashed, have said to each other: "How industrious we are! How wise we are! How favored we are by Heaven!"

In foreign relations we have been so successful that success has come to seem our due; any suggestion of yielding a part of a field of controversy arouses the guardians of the press. 
Undoubtedly one of the strongest elements in this genuine diplomatic success has been the fact that for many decades America was so far out of the routes and currents of world traffic and adventure that our preference was not gainsaid by powerful nations. Therefore we failed to realize that our peace and our diplomatic successes were exactly like the gifts of nature, - timber, rich soil, minerals, - immense blessings which are bound to be exhausted sometime. We need Conservation of our position in the world just as much as of our physical resources. We have had our way, not because of virtue and courage but because nobody thought it worth while to dispute our place in America. It is time to free ourselves of the delusion that any portion of the surface of the earth can be fenced off as a sphere peculiar to ourselves.

In like manner we must give up the belief that we are the most intelligent and highly educated nation on earth. If Americans descended from the Colonial English stock, had a superior fibre to their near cousins in England and their remoter cousins on the Continent, they have been willing to weaken that fibre, by bringing in those near and far cousins in vast numbers. "Best people on earth!" says the "Man from Home" in his delightful play. Who will dispute the sage from Kokomo or disclaim the rightmindedness of his countrymen? What we need is that this native shrewdness and kindliness should take account of the solid fact that Americans cannot have everything that they desire, even in their own latitude. It has become almost a principle of statecraft that public opinion in the United States is decisive in America and very influential in Europe.

That agreeable superiority has had to endure some softening. We have learned new things about the difficulty of living in the troubled world. Our possession of the Philippines has taught us something of the perplexities of colonizing nations, and has disabused us of the idea that we are the only great people who disdain to inflict upon weak races a distasteful government. We have learned something also about the difficulties of legislation on complicated subjects of international trade, such as discriminating rates in an international Canal, and the grant of lower tariffs to goods brought in American bottoms. The time has come also to recognize that in our relations with the Western Hemisphere we must take account of what other 
people wish; that neither Latin America or Europe will any longer accept as a reason for our action the statement that we prefer a Doctrine of Permanent Interest; or that such a Doctrine is international law, or, at any rate, international practice, simply because it is good for us. No American statesman will ever again inform Europe, as Mr. Olney did, that "The United States is practically sovereign on this continent, and its fiat is law upon the subjects to which it confines its interposition."

\section{THE WORLD'S BELIEF IN FORCE}

The conditions of the world call for modesty, foresight, and preparation by the United States. This is a great nation, its continental population of one hundred millions is the largest aggregate of Western people under one government, except the Russian Empire. Our population is one half greater than that of Germany, more than twice as great as that of Great Britain and Ireland, and larger than France, England, and Spain taken together. This is one of the world's great units; in most parts of the country, the population is still much below what the land would support. While Germany and Italy are elbowing for room for their own people, we invite millions from elsewhere, to help fill our unoccupied land.

Size is no measure of world greatness; but mankind has up to this time been much impressed with the potentiality of America. Here is a country which might raise ten million troops, build a thousand ships of war, land vast armies in Europe and Asia. The world, however, is just now learning a lesson of the weakness of strong nations; of the inability of millions of soldiers to push aside and overrun a smaller number of millions. France, Italy, and Russia are not only populous but supposed to be armed to the teeth; and they have all felt the misery of him who bites the file. Into the world has come the big brutal fact that no nation conquers or protects itself by its mass. All the efforts of humanitarians and writers on public law to reduce the realm of force by agreements among nations that in case of war they will forego some of their advantages, are broken down. Down to 1914 any international lawyer would tell you that it was illegal to use bombs dropped from air ships, poisonous gases, fiery liquids, and explosive 
bullets. He would give you abundant reasons why such practices were useless as well as barbarous. Every one of them is now being used to some extent, and nearly every one is being used in retaliation by armies which profess horror at such savage practices.

All men of good will hope that when the terrific storm and stress of this war have passed, there may be a return to the milder methods of the past. No one nation is responsible for the present worship of power. Many nations may co-operate in an era of peaceful adjustment. In the midst of all these efforts, stands the hard obelisk of physical force. So long as one great nation on earth desires war and is willing to risk war, all the good will and humanity of the rest of mankind is brought in question. Nations which are not founded on force, which do not love it, which practise reason and argument in their governments, are brought against their will into the conflict of weights. Unless they have big guns, swarms of heavy ships, prodigious transportation, masses of soldiers, they are subject to destruction by those who know how to combine those elements into the most crushing and terrific human projectile that the world has ever known.

When the war broke out in 1914, a neglected book suddenly sprang into world knowledge. This was Bernhardi's cool, cynical, cuttingly-phrased statement that the doctrine of force was soon to have its test. Bernhardi harks back to Treitschke, at whose feet the author of this book once sat as a student and disbelieved his master. He appeals also to Nietzsche, the denier of modern civilization. They all reach back to Gneisenau and Frederick the Great. No wonder they seem to Americans a kind of Anti-Christ, for their gospel is frankly the same as Napoleon's "God is on the side of the strongest battalions." Yet these writers all begin with the most undeniable proposition in the world - namely, that superior force must conquer inferior force. The Greeks knew that at Salamis and the English at Waterloo. The new and the harmful part of the doctrine put forward by these Germans is their appeal to their countrymen to cultivate force as the approach to all the manly and desirable virtues upon which a state can be built. First conquest, then your own terms, then a re-civilization of the conquered, and all this to make your own country great!

If this is a principle upon which permanent empires can be 
built, then it is the war cry of the future. Other powerful empires like that of the United States are founded upon the counter idea of accommodation, of the expression of the various wills of regions, races, and individuals, of mutual understanding within a country and between countries. The United States is definitely committed to the belief that force is the last remedy and not the first, that force can be avoided by wise and considerate government; that the worship of force degenerates into the worship of those who exercise that force, till the sword and the helmet and the shoulder-straps seem the most beautiful and splendid things on earth.

\section{FORCE UPON LATIN AMERICA}

The doctrine of peace has made no startling inroads on our twenty neighboring republics. Three of them, The Argentine, Brazil, and Chile, in the last twenty years have come out of the hurly-burly of internal and civil wars, have straightened out their boundaries for the most part, and have a distinct sense that this is their opportunity to develop in wealth, commerce, and in intellectual life. Two of them have immense territories, a great part of which is still untenanted; and Chile is geographically so shut in as to take away the temptation to enlarge at the expense of neighbors. Since the war with Peru in 1879-81, Chile has been in possession of the only piece of Peruvian territory which had a money value, in the provinces of Tacna and Tarapaca with their immensely valuable nitrate beds. Few countries in the world are so free from present desire to expand beyond their present boundaries as the A B C Powers.

Mexico is contracted like Chile, shut in by bounds which the disorderly republic could hardly extend: on the north the United States; on the South, Central America, which is now coming under the direct protection of the United States. Mexico, Colombia, Venezuela and Peru are a group of four large territorial states which furnish in one or the other almost an annual example of the real impediment to peace, and therefore the real necessity for the Doctrine of Permanent Interest. What might be termed the middle group of Latin-American States suffer from revolutionary habits which have been sufficiently described in previous chapters. The difficulty is an 
imperfect civilization. Their revolutions require some sort of regulating Doctrine, but forbid that Doctrine to be one of complete peace.

This uneasy relation between a peaceful Doctrine and forcible revolutions is still better illustrated in the third group of LatinAmerican States, the small and unreliable. The policy of our government toward these communities seems based upon the idea that where Uncle Sam sets his foot, disorders must cease. So far, the apparent belief that the five once independent states now reduced to American Protectorates will make no more mischief, has been borne out; but there are two strong reasons for believing that sooner or later there will be revolutions in those communities. The first is that it is in their blood: Haiti has never had a settled government in a hundred years; and to deprive the Central Americans of their revolution is like depriving them of their bull-fight - it grieves their sense of morals. The other reason is that the United States cannot prevent risings in our own borders: West Virginia and Colorado have both suffered within a few months from what was really an armed revolution, accompanied in some cases by assumptions of arbitrary power by the regular government which remind one of Latin-American dictatorship. It is hardly reasonable to expect a mixture of Spaniards, Indians, and Negroes to be fonder of peace than a mixture of English, Hungarians, and Slavs, brought together by the accident of employment. There will be no permanent peace either in the independent states or in the protectorates without some pressure from outside; and pressure is force, and may be war.

The necessity of keeping peace in both free and dependent territories is bound to make the United States more or less military. When Santo Domingo defaulted on its bonds ten years ago, that was no offense against the United States, though held to be a reason for intervention. If Santo Domingo should now try to get back where it was in 1904, it would involve a denial of the authority of the United States and would be treated as rebellion. The word was even applied to the Haitians in 1915, when they tried in a feeble way to resist the handful of American troops sent down to establish what is virtually an American Custom House. The term was earlier applied to the Filipinos who set up the plea that they could not be rebels to people whom they had never known before, with whose 
government they were not acquainted. Our protectorates are a standing incitement to the use of military force in keeping up civil government.

The United States has always shown forbearance and good nature toward the middle group of Latin powers. We have never had war with Bolivia or Ecuador or Uruguay, though the United States Navy showed its teeth to the Paraguayans in 1859. With the exception of Venezuela, none of them has put to the proof the Roosevelt Doctrine that the United States stands between them and the temporary occupation of their territory with a view to the collection of debts due to foreigners. What would happen if the Venezuelans were again to treat German and English subjects and contracts as they did in 1902 ? Is there any reason in law or morals or public policy why a United States official should not be placed at the head of the customs organization of Venezuela as well as of Haiti, if the behavior of the two governments be the same? We are proceeding in the name of the Monroe Doctrine to illustrate the motto of Massachusetts "Ense petit placidam sub libertate quietem" - "With the sword we seek quiet peace under freedom." However creditable, however necessary, however unavoidable, this makes of the Doctrine of Permanent Interest, a policy which not only may require war but in the end implacably will require war.

\section{TEMPORARY DEFENSIVE ALLIANCES}

A possible method of protecting the Doctrine would be either a previous understanding or a special treaty by which the Saxon and Latin-American states should protect each other in case of need by a union of military forces. Under present conditions the United States would be expected to furnish nearly all the naval power for such a war; while the Latin-American forces would be chiefly land troops which conceivably might be transported into a field of war outside their own country.

Any tyro in military affairs can see at once the difficulties of an effective alliance between powers which are not connected by land routes. An Inter-American railway was proposed as far back as 1890, and many links are now in existence. It would be a great help in such warfare, but for the fact that no steps are taken to complete it; and that it would be subject to breakage 
by enemy occupation of the Isthmus if it were constructed. Concentrated operation would require transport by sea on an immense scale. In fact, inasmuch as nearly all the LatinAmerican countries have seacoasts, the likelihood is that each one would hold its troops back for self-defense against possible invasion. We can hardly conceive of Brazil allowing the transfer of a hundred thousand troops from the Amazon to help defend the Chesapeake.

The difficulties of concerted action under common command are manifest. Doubtless the United States would always be willing to furnish commanders for Mexican or Chilean contingents; would there be equal readiness to place American army corps and squadrons under Colombian or Ecuadorian generals? The utmost that could be expected is that all the capable powers would agree to fight like devils while the war lasted. In case of a defensive war against a strong naval power, nobody could be sure where the blow would fall. Sound tactics would seem to direct a European enemy toward the richest part of America, where most harm could be done and most progress could be made toward compelling a favorable peace. If an English or a German army were to land on the Jersey coast there seems very little hope of aid from the Southward; on the other hand, an attempt by a European power to conquer Cuba, Mexico or Brazil would give scope for the American navy.

Such dangerous times may come that every American power will accept any allies that it can find ; and there may be means of combining the 176 million people in America (outside of Canada) for military purposes. Still, in this day of swift attack and terrific impact, the United States is bound to bear the shock of any European invasion. In the long run, one might organize a joint force of combined America, which could defend the most vulnerable points in both hemispheres. However, there is no force known to man except a powerful navy which could prevent a strong, determined enemy from landing where it listed, in either North or South America or the West Indies, at places very unfavorable to the defenders. The difficulty with any defensive alliance is that it multiplies points of attack on both continents, without really strengthening the one power which must bear the brunt of an Inter-Hemisphere war. 


\section{FORCE UPON NON-AMERICAN POWERS}

After all, people who think about it are aware that war is an unwritten part of the Doctrine of Permanent Interest; but it is supposed to be war against weak and disorganized peoples whose resistance must be brief, so that the loss of life and property will be trifling. Our experience in the Philippines suggests that a weak and poorly armed people who methodically hate us can make it very difficult for large bodies of more highly civilized troops. Should we send troops to Mexico, there will doubtless be another lesson as to the cost of precious lives in putting to rights a weak and disorganized people. Modern warfare, however, shows clearly that no fortresses, not even those built by the richest and most scientific people, will stand big gun fire; and that an army without modern artillery is nothing but a target for slaughter. With the means now at her command, the United States could easily deal with her Protectorates, even if all should rise together; and our antiquated military system would probably furnish sufficient in troops and organization to meet any belligerent American neighbor, or any combination of such neighbors that is likely to be made against us. Is that all that is needed for defending the Doctrine of Permanent Interest?

Though the Doctrine works against the Latin-Americans, it is intended to work against other powers. If some of those other powers push the question to an issue, who is going to take the responsibility of resisting them? The review in the previous chapter of the various peaceful methods suggested for the maintenance of the Doctrine of Permanent Interest shows the inherent weakness of all methods which depend upon dividing the responsibility between the American powers. The United States announced the Doctrine, regulates it, applies it, profits by it; the United States alone can enforce it. It is a militant doctrine in so far as the United States means to defend her diplomatic principles at all hazards. The American people appear to believe that the decision as to their intention to fight for it may be safely postponed until they are asked to fight for it. Upon this question the best military authorities appear to be agreed that the Doctrine will lead to war if we adhere to it; it is bound to lead to war if any powerful nation is willing to risk war with us for the sake of what it may pick up in America. 
An old tradition holds that it is unthinkable that the United States should ever be actually involved in war with a European power. That cherished belief has had many hard knocks. One was the Spanish War, in which the United States enjoyed the dangerous sport of breaking down one of the weakest of the middle group of European nations. A basis for the belief is the manifest unwillingness of Great Britain to come to fisticuffs with the United States. Canada and the West Indies and Newfoundland have become hostages for English friendship. France and Russia have no quarrels with us, and most people nowadays, when they muse upon war with Europe, mean only war with Germany.

The Monroe Doctrine, The American Doctrine, The Doctrine of Permanent Interest - call it what you will - is an announcement to the world, a promise to Latin America, and a pledge to the American people, that the United States will resist Germany or any other European or Asiatic country which may attempt to invade any part of the Western Hemisphere - Canada included. Resistance which does not resist has no place in this wicked world. A sensible people must make up its mind how far its resistance means a willingness to meet the cost and sacrifices of war.

\section{MUST THE UNITED STATES HAVE A DOCTRINE?}

In view of these difficulties, might not the United States simply withdraw her claims to any form of special Doctrine, while preserving the ultimate right of self-defense which is every nation's guerdon. Why not treat the Doctrine as unnecessary and obsolete? Why not leave other states to the process which Bismarck so piquantly suggested for France: "Let her cook in her own gravy"? Why should we bestir ourselves about countries more distant from us than either Europe or Asia? The answer is that the United States does not cherish the Doctrine of Permanent Interest for the sake of other countries but for our own welfare. "Giving up the Monroe Doctrine" would not relieve us from the dangers and hostilities which would result from new European settlements in any position which gave command of our coasts or of the approaches to the Panama Canal. Great Britain has points of vantage in those waters, but seems to have no enterprise on foot in America, south of Canada. 
It is much more likely that the Bermudas, the Bahamas, Jamaica and the Lesser Antilles will eventually be amicably transferred to the United States than that they will be used by England as bases for naval warfare against us.

No formal assurance to the world that we are not interested, especially in the Caribbean, Central America, and the Northern part of South America, will ever take away the fact that we are and must be interested. It is now out of the power of the United States to decide whether it is worth while to hold the region about the Gulf of Mexico. A combination of Latin-American powers with European or Asiatic powers against the United States is very improbable, because, whatever our lack of confidence and regard toward the Latin-Americans, we are more interested in their permanence than is Germany or Japan. Still, such a combination is not impossible, and the easiest way to prevent it is to ward off all remote approaches toward the planting of non-American powers in America.

If the flank of the United States would be exposed by the invasion of a neighboring country, it is equally true that the invader must present a flank toward us. With or without a Doctrine of Permanent Interest, the chief obstacle to the establishment of colonies by an external power will always be the United States. Therefore, some bold and military foreign nation, possessed of a great navy and army, may sometime find it good military tactics to attack the United States, and if possible, put us out of the game, as a preliminary to seizing other American territory. No abdication of the Doctrine of Permanent Interest would dispose of the three geographic facts that the United States is in the middle of the Americas, owns the Panama Canal, and controls three large West India Islands and at least two Central American states. Nor is the spirit of the American people one which is willing to secure peace and safety by undertaking beforehand not to be aroused by such a conflict. The last favorable time to give up the Monroe Doctrine was when Seward began to lay the foundations for a Canal policy of ownership and management. The Canal cannot be held except on terms and by efforts which require us to be either masters or allies of the neighboring countries.

The bulwarks of International Law are apparently giving way, and we have contributed to that result by accepting the maxim of European statesmen that weak nations of inferior 
racial or military power are a legitimate prey for stronger nations. That principle has been carried out in Poland, in the Balkans, in Turkey, in Central Asia, in China, in the Pacific Islands and in Africa. Of late it has been applied to Belgium. It is familiar to us in the West Indies and Central America. It will infallibly be transferred by Europe to America, if there is sufficient motive and sufficient strength. Balances of power in Europe may delay it; the suffering and weakening caused by the present war may postpone it ; but the only effective obstacle to-day, and far in the future, must be the resistance of the United States.

\section{READINESS TO PROTECT THE DOCTRINE}

.For two reasons, the United States is willing to stand by the Doctrine though in the end it lead to war. One is the national love of moral principles. Our fathers in the American Revolution felt that they were battling for self-government. Their sons were aroused by the cry of "Free trade and sailor's rights." The cause of the Civil War was rival moral theories on the rights of man over man. The Spanish War of 1898 began as a humanitarian movement for the relief of suffering. Perhaps it would be hard to raise volunteers for our army if the only object were to prevent the Germans from seizing Tierra del Fuego or the Japanese from making war on Chile. The United States is not likely to declare war on anybody simply from friendship and sympathy for somebody else; but the statesman who assures his countrymen that bold and desperate men are attacking the sacredness of the Monroe Doctrine, will probably carry them with him into war for the principle.

Another influence which is certain to make itself felt is that of hostile fleets and armies passing and re-passing along our coasts and islands, where the only fleet bent upon destruction that has been seen for near a hundred years was the unfortunate squadron of Cervera in 1898. We feel little interest in the throatcutting of one Latin-American by another, but a profound dislike of the same process when applied from outside the boundaries of America.

In any case, the United States is rather a sensitive nation and ought to see where danger lies. The present European War shows how the devouring flame of war spreads from country to country. War in the Caribbean, or Central America, or Mexico, 
or Colombia is next door to the United States; and war in Brazil or Chile, or the Argentine, would be looked upon as preparing the ground for a later approach to our frontiers.

Upon the face of things, the country is ready to accept the danger of war, whether for the Doctrine of Permanent Interest or for the protection of foreign trade, or for any other obvious national interest. Certain newspapers have made it their business for many years to blow up the coals ; and have boasted - perhaps with reason - that they brought on the war of 1898 . To read the editorials, one would think that the American people are on the qui vive to assert the dignity and power and policy of their country. During the European War there have been many incitements to take part on one side or the other. Since the Doctrine of Permanent Interest is accepted by the American people, embodied in state papers, known to all nations, and concerns the vital interests of the United States, of course it must be defended.

\section{WAR FOR THE DOCTRINE}

Is the nation, is Congress, are the newspapers, really ready to carry out their own bold determinations? If so, they must face the difficulties and the cost. Potential armies and navies are no longer regarded. In a world which has just seen the might of England and of Russia defied, small preparations and weak forces simply do not count. The only proof of a genuine belief in the Monroe Doctrine and a real intention to carry it out, is willingness to provide the men and the ships, without which it will eventually become a scoffing and a by-word. The reports of actual military and naval preparations rendered by the War and Navy Departments from year to year, seem to show that the people of the United States are not willing to make the necessary sacrifices to defend even their own boundaries.

The country seems to have learned nothing from an experience of a century and a half. Washington clearly and vainly pointed out to Congress that militia were a costly and unreliable kind of military force, yet militia have been the main dependence in every war since his time and apparently are expected to do most of the fighting in any future war. In the Civil War, the cost of military operations on both sides, in supplies and men, was three times what it ought to have been to do the work. 
In the Northern armies in that war, out of two million men enlisted, one hundred twenty-five thousand desertions are reported. Many of the deserters eventually returned to their own commands; some of them deserted many times. Sixteen thousand officers were removed from the service for incapacity and similar causes. In the Spanish War of 1898 a proud republic of ninety million people succeeded, two months after the declaration of war, in sending seventeen thousand men to Cuba! The transports of the army were chartered vessels which refused to obey the orders of the commander of the squadron. The confusion, loss, and sacrifice of needless life was a national humiliation. In the whole war 345 men died from wounds and 3850 from disease !

The army has since been increased: for a like trifling expedition forces and transports could now be found within a few days; but seventeen thousand men could not occupy and defend two miles of the lines of trenches which characterize modern warfare. Congress has never authorized the men, the guns, the ammunition, the officers, the military and naval staff which would be necessary for any real defense against an invading European force. When the European War is over, this country will be at the mercy of any one of a half a dozen foreign powers that might feel hostile - or would be at their mercy, but for our navy. The defeat of that navy by a combination of powers or by a single power, would lead in a few weeks to an invasion of the United States; the people of this country would then learn the real significance of "Extend their political system to any portion of either continent," and "for the purpose of oppressing them, or controlling in any other manner their destiny, by any European power." Without a different kind and degree of military preparation on our part, the time may come when Brazil will pronounce a new doctrine forbidding European nations to meddle with the feeble United States!

The combination of great sensitiveness as to any movement against other parts of America, alongside an unwillingness to expend either the money or the skill necessary to enable us to aid our neighbors, spells disaster. If we stand by the ordinarily received Doctrine of Permanent Interest, it is in the power of any one of twenty other American powers to antagonize some European power, and thus to exact from us a resort to war. The United States has snuffed out six of these highly charged local bombs by our new system of protectorates; but there is a 
limit to the relief which can be had by that means. Every one of those protectorates must be protected or abandoned, in case of war. On one side, the United States is loading up with weak dependencies in Asia and America which are incapable of selfdefense, and which we must police and if necessary garrison. On the other side, while thus increasing the present need of a strong army and navy, the United States satisfies herself with a force which could not even defend our own coasts.

\section{FACTS OF THE DOCTRINE}

No prophet since the time of Elijah has enjoyed predicting evil; and, no observer can be sure that he has taken into account all the elements of his problem or has given them proper weight. The fixed facts with regard to the Monroe Doctrine may be summarized as follows :

1. It arose out of new conditions in the world, particularly the creation of a group of nations, which confused the old formulas of state policy.

2. It was founded in a genuine spirit of good will and sympathy with distressed republics, and to this day international sentiment plays a considerable part.

3. Considerations of business and commerce had little to do with its origin and do not much affect the problem now; for the United States has made, and is making, no systematic attempt to secure Latin-American trade.

4. From the first, the Doctrine was defensive, its main purpose being to relieve the United States from dangers to herself arising out of such changes of territorial status as would bring strong and aggressive powers into territory then occupied by weak powers.

5. The Monroe Doctrine has never stood in the way of the territorial expansion of the United States; and at present a process of making dependencies out of the nearer and weaker Latin-American States is going on briskly, thus tending to produce a composite Saxon-Latin empire.

6. The Doctrine in all its phases accords with the state policy of other parts of the world and has its counterpart in the near East and in eastern Asia. 


\section{A GUESS AT THE FUTURE}

Some obvious deductions from these facts and from the general condition of the world are as follows :

1. Till recently, there has been little to tempt European nations in the conditions of America ; but they have been drawn in by trade, are affected by civil wars and dissensions and, to some degree, by their people who have emigrated to South America.

2. The effect of the great European War is to encourage the Doctrine of the Strongest and a spirit of adventure on the part of powerful nations. The likelihood of an invasion of America is greater than at any previous time.

3 . The United States is compelled to take account of these changes in the world's conditions, not because there has been a paper Monroe Doctrine, but because such a change in the status of America would be threatening and ultimately dangerous to the United States.

4. The force of the circumstances and conditions therefore compels the United States to feel a special solicitude which is expressed by the term Doctrine of Permanent Interest.

5. The Doctrine of Permanent Interest is difficult to maintain peacefully, even toward the other American states; and unless Europe is about to enter on a new régime of international understandings and good will, which seems very ${ }_{a}$ doubtful, the Doctrine is likely to be tested by some ambitious military power.

6 . For such a contest the naval preparation of the United States is insufficient and her military organization is preposterous. Either the country must face the responsibility which it assumes and prepare itself accordingly, or it must give up the Doctrine.

7. The Doctrine will not give up the United States; for European settlements in America can only be made by war upon American countries, which would inevitably involve the United States sooner or later, with or without a Doctrine.

Briefly put, the so-called Monroe Doctrine is a formula which expresses a fact and not a policy. That fact is inherent in the political geography of the Americas and in the conditions of modern warfare. Even so peaceful a country as the United States, which desires no war and is bound to suffer heavily from any war in which she engages, whether victorious or defeated, may not have the choice. Peace can be maintained only by 
convincing Germany and Japan, which are the two powers most likely to be moved by an ambition to possess American territory. But the United States will defend her interests even though they seem at first to be only indirectly affected. If we are not prepared to take that ground, the Monroe Doctrine is dead.

If we are willing to go to that limit, it must be proved by intelligent preparation. That means a kind of organization through powerful general staffs and centralization of the War Department and Navy Department, which Congress has never been willing to authorize. It means an enlargement of the military and naval forces and ultimately some form of military training of the Swiss type. It means a willingness to face the world as it is, and no longer to live in the delusion that we are protected by a paper Doctrine of Permanent Interest. 



\section{PART VII}

\section{MATERIALS}

\section{CHAPTER XXV}

\section{BIBLIOGRAPHY OF THE MONROE DOCTRINE AND OF ITS COLLATERAL DOCTRINES}

\section{CRITERION}

To prepare anything like a complete bibliography of the Monroe Doctrine in its broadest sense, would be a long and severe task; for there is a large literature of private materials, published records, and secondary discussions which no one has as yet sought to assemble and to put in order, so that it may be used by inquirers. The only approach to such a bibliography has been made by Dr. Herbert Kraus in his Die Monroedoktrin, which is described below. Though he has listed some periodical articles in his section "Von der Monroedoktrin handeln", he has made no attempt to exhaust the periodical material; nor has he gone far into the often illuminating discussions in biographies and in general histories of the United States and of other American countries.

The author has confined this bibliography to a limited number of selected book titles. In order to bring the results within reasonable compass, periodical articles have been entirely omitted, although many of them contain information and discussion of the first order.

Many suggestive articles can be reached through the standard indexes to periodicals (See Channing, Hart and Turner, Guide to American History § 24) including Leonard A. Jones, Index to Legal Periodical Literature (2 vols. 1888-1899).

Likewise the numerous and fruitful treatises on public international law have been left out, though they contain extracts 
from sources and expert discussion of great value. The most important ones can be reached through the author's Foundations of American Foreign Policy, ch. viii, "A brief Bibliography of American Diplomacy"; and more specifically through Kraus's section (pp. 27-31) "Völkerrechtliche Werke allgemeinen Inhalts."

This Bibliography is sub-divided into five heads as follows ; -

1. Bibliographies of the Monroe Doctrine.

2. Compendiums containing Material on the Monroe Doctrine.

3. General Diplomatic Works, containing Material on the Monroe Doctrine.

4. Works treating specifically of the Monroe Doctrine.

5. Printed Sources of the Monroe Doctrine.

\section{BIBLIOGRAPHIES OF THE MONROE DOCTRINE}

Some of the treatises on the Monroe Doctrine contain lists of authorities, though none of them except as noted below, are of much use to the searcher. Professor John B. Moore, in his two majestic collections of material and discussions of American diplomacy, has printed long lists of books bearing on all questions of diplomacy; and his texts with their copious footnotes give access to a vast amount of valuable material on the Monroe Doctrine.

Channing, Edward, and Hart, Albert Bushnell, and Turner, Frederick Jackson, Guide to the Study of American History, (Rev. and aug. ed., Boston, Ginn, 1912)

Special bibliographies relating to the Monroe Doctrine at $\$ \S 198$, 199, 224, 244, 257, 263, 267.

Gilman, Daniel C., James Monroe. (Boston, Houghton, Mifflin, 1898)

Bibliography by J. Franklin Jameson at pp. 260-294. Good up to its date.

Hart, Albert Bushnell (Editor), The American Nation: $A$ History. (27 vols. 28th in preparation, N. Y., Harper, 19041907 [1916])

In each volume a "Critical Essay on Authorities", including in most cases diplomatic material. 
Hart, Albert Bushnell, The Foundations of American Foreign Policy, with a Working Bibliography. (N. Y. and London, Macmillan, 1901)

A brief select bibliography of American Diplomacy at pp. 241-293.

Hart, Albert Bushnelu, Manual of American History, Diplomacy, and Government. (Cambridge, Harvard Univ., 1908)

Contains specific references on The Monroe Doctrine and collateral topics, at $\$ 74$ (Lect. 35-36), \& 76 (Lect. 43), $\$ 77,78$ (Lect. 46-50), $\S 80$ (Lect. 57-64), \& 82 (Lect. 71), §84 (Lect. 75-78), § 86 (Lect. 82-84, 87-89), §§ 145, 152, 163, 167, 171, 172, 183, 196.

Hasse, Adelaide R., Index to United States Documents relating to Foreign Affairs (1828-1861). (3 Parts ; Part I, “A-H," published; Washington, Carnegie Inst., 1914)

Copious analysis of the correspondence, etc., which was printed in interval between the Am. State Papers, Foreign and the Diplomatic Correspondence.

Kraus, Herbert, Die Monroedoltrin in ihren Beziehungen zur amerikanischen Diplomatie und zum Völkerrecht. (Berlin, Guttentag, 1913)

Thoroughgoing bibliography at pp. 19-36, classified as follows: (1) Sources; (2) Periodicals and Technical Journals; (3) Works relating to Diplomacy, History, or Politics; (4) Works on International Law of a general Character; (5) Books and Periodical Articles [especially relating to the Monroe Doctrine].

Place and date are stated for all book titles. References to periodicals so cited as to be easily verified. In addition, the work abounds in bibliographical footnotes, many of which are collections of references to sections or paragraphs of the work.

This is the best bibliography of the Monroe Doctrine.

Moore, John Bassett, Digest of International Law as embodied ... especially in Documents . . . of the United States. (8 vols., Washington, Gov. Printing Office, 1906) (This is House Docs., 56 Cong. 2 sess. No. 551).

General bibliography of International Law in Vol. I, pp. ix-xxx. References in index in Vol. VIII under title "Monroe Doctrine" lead to invaluable extracts from treaties, opinions, and despatches.

Morrison, Hugh A., Jr., List of Books and Articles in Periodicals relating to Interoceanic Canal and Railway Routes. (Washington, Gov. Printing Office, 1900)

Questions of general American policy. The Monroe Doctrine is incidental. 
Ringwalt, Ralph Curtis, Briefs on Public Questions, with Selected Lists of References. (N. Y., Longmans, Green, 1905)

An elaborate brief on the Monroe Doctrine with references at pp. 84-92.

United States, General Index to the Published Volumes of the Diplomatic Correspondence and Foreign Relations of the United States (1861-1899). (Washington, Gov. Printing Office, 1902)

Very full and highly analyzed both by countries and by topics. A few references only under the specific title "Monroe Doctrine."

\section{COMPENDIUMS CONTAINING MATERIAL ON THE MONROE DOCTRINE}

Every student of American diplomacy is aware of the difficulty of placing a particular episode or negotiation in its exact chronological place and its connections with other events. The searcher for exact data and the verification of results, can be much aided by the following brief list of compendious works, which gives information about past diplomacy, in many cases brought down almost to date. Through them new phases of the subject can be traced as fast as they arise.

The American Journal of International Law. [Quarterly] (Washington, Am. Soc. of Int. Law, 1907-date)

Each number contains a "Chronicle of International Events" commencing January 1, 1906 "with References." This is the standard list of diplomatic events, including Latin America. There is a supplement of official documents.

The American Year Book: a Record of Events and Progress. [Annual, beginning with year 1910] (N. Y., Appleton, 1911-date)

Contains articles under "International Relations" and "Foreign Affairs." Full and well selected. Most convenient source for current diplomatic questions.

The Annual Register. Review of Public Events at Home and Abroad. [Annual, beginning with year 1758] (London, etc., 1761-date)

Compilation of documents and also secondary statements of events. Appletons' Annual Cyclopxdia and Register of Important Events [Annual, 1861-1902]. (42 vols., N. Y., Appleton, 1862-1903)

Volumes for 1861-1874 are called American Annual Cyclopadia. Three Indexes, 1875, 1895, 1902. 
Cyclopedia of American Government. (3 vols., N. Y., Appleton, 1914)

Articles "Canal Diplomacy"; "Central America"; "Cuba and Cuban Diplomacy"; "Drago Doctrine"; "Pan American Congresses"; "South America, Diplomatic Relations"; "Foreign Policy of the U.S."; "International Law"; "Influence of the U. S. on Latin America"; "Monroe Doctrine" and countries by name. See Index, and cross references. The articles are provided with brief bibliographies.

The Encyclopadia Britannica. Eleventh Edition. (29 vols., Cambridge Univ. Press, 1910-1911)

Art. "Monroe Doctrine" (brief) and Latin-American countries by name. Not very serviceable.

The International Year Book. A Compendium of the World's

Progress. [Annual, 1898-1902, 1907-date] (N. Y., Dodd, Mead, 1899-1903, 1908-date)

No articles on this specific subject: only on Latin-American countries by name.

The New International Encyclopodia. (20 vols., N. Y., Dodd, Mead, 1905; new ed. in progress, 1915)

See Art. "Monroe Doctrine" and Latin-American states by name.

Political Science Quarterly. A Review Devoted to the Historical, Statistical, and Comparative Study of Politics, Economics, and Public Law. (N. Y. etc. Ginn, 1886-date)

Edited by the Faculty of Political Science of Columbia University. Semiannual (June and December) "Record of Political Events"; begins in Vol. IV (1889); affords a convenient chronological background.

The Statesman's Year-Book. [Annual] (London, Macmillan, 1864-date.) etc.

Articles on countries by name, with latest statistics, bibliography,

Tillinghast, William Hopkins (Compiler), Handbook of Universal History from the Dawn of Civilization to the Outbreak of the Great War of 1914. Ploetz's Epitome, translated and enlarged with Additions covering Recent Events. (Boston, etc., Houghton, Mifflin, rev. ed., 1915)

The most convenient book for exact dates of significant events, treaties etc. 
III. GENERAL DIPLOMATIC WORKS CONTAINING MATERIAL ON THE MONROE DOCTRINE

The Monroe Doctrine is so significant that it has engaged the attention of all the general historians of the United States who have dealt with the period from 1808 to the present day. Among these general authors are the following; -

Beard, Charles Austin, Contemporary American History. [18771913] (N. Y., Macmillan, 1914)

Hart, Albert Bushnell (Editor), The American Nation; $A$ History. [1492-1907] (27 vols., N. Y., Harper, 1904-1908)

McMaster, John Bach, History of the People of the United States. [1783-1861] (8 vols., N. Y., Appleton, 1883-1913)

Rhodes, James Ford, History of the United States from the Compromise of 1850. [1850-1877] (7 vols., N. Y., Macmillan, 18931906)

Schouler, James, History of the United States of America under the Constitution. [1783-1877] (7 vols., N. Y., Dodd, Mead, 1895-1913)

Wirson, Woodnow, History of the American People. [1492-1900] (5 vols., N. Y., Harper, 1902)

The principal books on the diplomatic history of American relations are included in the following list. Many of these works, through footnoteś and other bibliographical apparatus, lead readers and investigators to good materials for extending their information.

Barrett, John, The Pan American Union: Peace, Friendship, Commerce. (Washington, Pan American Union, 1911)

Benton, Elbert J Jy, International Law and Diplomacy of the Spanish-American War. (Baltimore, Johns Hopkins, 1908)

Deals with causes of the Spanish war. - Not much on other than Cuban relations.

Callahan, James Morton, American Relations in the Pagific and the Far East (1784-1900). (Baltimore, Johns Hopkins, 1901)

Includes questions of Pacific dependencies. 
Callahan, James Morton, Cuba and International Relations; a Historical Study in American Diplomacy. (Baltimore, Johns Hopkins, 1899)

Systematic account of Cuban relations. Some discussion of Monroe Doctrine in chs. vii-xi.

Chadwick, French Ensor, The Relations of the United States and Spain. (3 vols., N. Y., Scribner, 1909-1911)

Vol. I, Diplomacy, is a study of relations with Spain from the Revolution to 1898 .

Coolidge, Archibald Cary, The United States as a World Power, (N. Y., Macmillan, 1908)

An original and serviceable book, containing suggestive discussion of the Monroe Doctrine at chs. vii, xvi, xvii.

Fish, Carl Russell. American Diplomacy. With Sixteen Maps. (N. Y., Holt, 1915)

Best single volume on American Diplomacy. Good discussion of the Monroe Doctrine at chs. xii, xvii, xx, xxiii, xxvii, xxviii, xxxi.

Foster, John Watson, Century of American Diplomacy; being a Brief Review of the Foreign Relations of the United States (17761876). (Boston, etc., Houghton, Mifflin, 1901)

Somewhat conventional, but useful on Monroe Doctrine. See chs. vii, ix, xi, xii.

García-Mérou, Martín, Historia de la Diplomacia Americana. Política Internacional de los Estados Unidos. (2 vols., Buenos Aires, Lajouane, 1904)

By an Argentine diplomat. Covers period 1775-1903. Analytic Contents, and Chronological Summary at Vol. II, pp. 457-462. Most complete work in Spanish.

Hart, Albert Bushneld, The Foundations of American Foreign Policy, with a Working Bibliography. (N. Y., Macmillan, 1901)

Ch. vii is on the Monroe Doctrine.

Henderson, John Brooks, Jr., American Diplomatic Questions. (N. Y., Macmillan, 1901)

Part IV (pp. 289-450) is devoted to the Monroe Doctrine, chiefly a study of the controversies. 
Latané, John Holladay, The Diplomatic Relations of the United States and Spanish America. (Baltimore, Johns Hopkins, 1900; another edition in preparation)

An excellent book on its subject.

Lawrence, Thomas Joseph, Essays on Some Disputed Questions in Modern International Law. (Cambridge, etc. Deighton, Bell, 1885)

Essay iii is on the "Panama Canal and the Clayton-Bulwer Treaty."

McMaster, John Bach, With the Fathers; Studies in the History of the United States. (N. Y., Appleton, 1896)

"Monroe Doctrine" at pp. 1-54, written at time of Venezuela controversy of 1895 .

Mahan, Alfred Thayer, The Interest of America in International Conditions. (Boston, Little, Brown, 1910)

Mahan, Alfred Thayer, The Interest of America in Sea Power, Present and Future. (Boston, Little, Brown, 1897)

With maps. A study of the geographical and naval conditions under which the foreign policy of the United States must act.

Mahan, Alfred Thayer, The Problem of Asia and its Effect upon International Policies. (Boston, Little, Brown, 1900)

Authoritative discussion of the purposes and rivalries of the United States and the various European powers in Asia.

Mathews, Lois Kimball, and Others, Essays in American History dedicated to Frederick Jackson Turner. (N. Y., Holt, 1910)

Collection of essays, by various hands. The last two are on LatinAmerican subjects.

Moore, John Bassett, American Diplomacy, its Spirit and Achievements. (N. Y., etc., Harper, 1905)

Topical arrangement. Ch. vi, on the Monroe Doctrine.

Moore, John Bassetr, History and Digest of the International Arbitrations to which the United States has been a Party, together with Appendices containing the Treaties relating to such Arbitrations, and Historical and Legal Notes on other International Arbitrations Ancient and Modern, and on the Domestic Commissions of the United States for the Adjustment of International Claims. (6 vols., Washington, Gov. Printing Office, 1898) (This is House Mis. Docs., 53 Cong. 2 sess., No. 212, also published separately.) 
Table of contents at beginning of Vol. I followed by "List of Authorities." Full general index in Vol. V at pp. 5085-5239. Title "Monroe Doctrine" does not occur, but material can be reached through such titles as "Claims ", "Citizenship", and countries by name.

This set contains numerous authentic narratives on controversies with Latin American countries which finally came to arbitration. Vol. VI. is made up of maps.

Moses, Bernard, The Spanish Dependencies in South America; an Introduction to the History of their Civilisation. (2 vols., N. Y., Harper, 1914)

Reinsch, Paul Samuel, World Politics at the End of the Nineteenth Century as influenced by the Oriental Situation. (N. Y., etc., Macmillan, 1900)

Author became minister to China in 1913. Book includes chapters on German interests in Asia and Africa, and Oriental interests of the United States.

Romero, Matias, Mexico and the United States; a Study of Subjects affecting their Political, Commercial, and Social Relations. (Vol. I., N. Y., etc., Putnam, 1898)

The author was long minister of Mexico to the United States.

Roosevelt, Theodore, American Ideals and Other Essays, Social and Political. (N. Y., Putnam, 1897)

Chapter xi on the Monroe Doctrine, written before the author became President.

Schuyler, Eugene, American Diplomacy and the Furtherance of Commerce. (N. Y., Scribner, 1886)

A good book for the time. Strong on commerce. Little on Monroe Doctrine.

Scruggs, William Lindsay, The Colombian and Venezuelan Republics, with Notes on Other Parts of Central and South America. With Maps and Illustrations. (Boston, Little, Brown, 1901).

By a former United States minister to Colombia and Venezuela. Treats Spanish-American conditions in chs. xii, xiii, xxi, xxii, xxiv.

Taft, William Howard, The United States and Peace. (N. Y., Scribner, 1914)

Three essays on arbitration, one on Monroe Doctrine (pp. 1-39). 
'Torres CaIcedo, José Maria, Union Latino-Americana, pensamiento de Bolibar para formar una Liga Americana; su Origen y sus Desarollos. (Paris, Rosa y Bouret, 1865)

By a Venezuelan public man. History of attempts at union from 1823 to 1861. Criticism of the "false interpretations" of Cass, Buchanan, etc. First careful study of Pan-Americanism.

Woolsey, Theodore Salisbury, America's Foreign Policy, Essays and Addresses. (N. Y., Century, 1898)

Much detail on Spanish War; then a variety of questions, including the Olney Doctrine of 1895.

\section{WORKS TREATING SPECIFICALLY OF THE MONROE DOCTRINE}

More than forty authors have been impelled to print formal expositions of their opinions upon the Monroe Doctrine. The result is a collection of works, many of which are authoritative and most of which are written in excellent style and spirit. The largest number are in English; but there are many French writers, especially since a French company undertook the Panama Canal in 1879. Several skilled and able LatinAmerican writers have taken part in the discussion and their works are among the most valuable that we possess. Most of them are in Spanish or Portuguese, some in French. In German there are only one or two formal contributions, but that of Kraus is the most significant work that hâs been prepared upon the subject.

Alvarez, Alejandro, Le Droit International Américan, son Fondement - sa Nature d'après l'Histoire Diplomatique des Etats du Nouveau Monde et leur Vie Politique et Économique. (Paris, Pedone, 1910)

A study of the political and international point of view of the LatinAmericans, by a Chilean. One of the best books.

American Academy of Political and Social Science, The Foreign Policy of the United States; Political and Commercial. (Phila., Am. Acad., 1899)

Contains at pp. 77-200 a discussion of the commercial and political relations of the United States with the Far East.

American Academy of Political and Social Sciences, International Relations of the United States. (Phila., Am. Acad., 1914) 
More than 20 addresses and communications on the Monroe Doctrine and Oriental diplomacy by various speakers. One of the most serviceable books on the subject.

American Academy of Political and Social Science, The Pan-American Conferences and their Significance. (Phila., Am. Acad., 1906)

Addresses by four Latin-American ministers.

American Academy of Political and Social Science, Political and Social Progress in Latin-America. (Phila., Am. Acad., 1911)

Fifteen addresses on various phases of Latin America, including the Pan-American Conference at Buenos Ayres.

American Academy of Political and Social Science, The United States as a World Power. (Phila., Am. Acad., 1905)

Collection of valuable addresses on many phases of the Monroe Doctrine.

Antokoletz, Daniel, La Doctrine de Monroë et l'Amérique Latine. (Paris, Larose, 1905)

In Library of Congress.

Barral-Montferrat, Marquis de, De Monroë à Roosevelt (18231905). Avec une Préface de M. le Comte d'Haussonville. (Paris, Plon-Nourrit, 1905)

A sharp arraignment of the United States. Includes Asiatic and European considerations.

Beaumarchais, Maurice Delarüe de, La Doctrine de Monroë. L'Evolution de la Politique des Étas-Unis au XIX $X^{e}$ Siècle. (Paris, Larose, 1898)

Highly critical of the policy and practices of the United States. Includes a brief but suggestive description of the economic elements.

Bigelow, John, American Policy; the Western Hemisphere in its Relation to the Eastern. (N. Y., Scribner, 1914)

Brief book; not especially helpful.

Bingham, Hiram, The Monroe Doctrine, an Obsolete Shibboleth. (New Haven, Yale Univ. Press, 1913)

Brief book criticizing the Doctrine and setting forth Latin-American objections. A few documents added. 
Blakeslee, George Hubbard (Editor), China and the Far East. Clark University Lectures. (N. Y., Crowell, 1910)

Chapters i, iv, vi, xviii are on the relations of the United States with China and Japan.

Blakeslee, George Hubbard (Editor), Japan and JapaneseAmerican Relations. Clark University Addresses. (N. Y., Stechert, 1912)

Chapters xvi, $\mathrm{xx}-\mathrm{xxii}$ on relations of the United States with Asia.

Blakeslee, George Hubbard (Editor), Latin America. Clark University Addresses. (N. Y., Stechert, 1914)

Collection of addresses on Latin America in a variety of phases. One of the best books on the subject.

Capella y Pons, F., Monrö̈sme? Notes-Études sur la Politique Continentale Américaine à l'Égard de l'Europe (Paris, Larose, 1913)

A lively survey and discussion of the subject by a Uruguayan. Critical of the United States.

Caylus, Ernest, Politique Extérieure des États-Unis. Doctrine Monrö̈. (Bordeaux, Gournourlhou, 1859)

Pamphlet with outline of discussions of 1822 to 1826 . Not significant.

Céspedes, José Maria, La Doctrina de Monroe. (Habana, Miranda, 1893)

In Library of Congress.

Crichfield, George Washington, American Supremacy; the Rise and Progress of the Latin American Republics and Their Relations to the United States under the Monroe Doctrine. (2 vols., N. Y., Brentano, 1908)

A furious and valueless attack on Latin-Americans.

Dunning, John Corliss, Die neuesten Anwendungen der Monroedoktrin. (Borna-Leipzig, Noske, 1908)

Edgington, Thomas Benton, The Monroe Doctrine. (Boston, Little, Brown, 1905)

Permeated with a theory of the superior rights of the United States in all cases. 
Fried, Alfred Hermann, Pan Amerilia, Entwickelung, Umfang und Bedeutung der pan-amerikanischer Bewegung (1810-1910). (Berlin, Maritima, 1910)

Very favorable to a general American Union. Many quotations and notes; analytic Table of Contents at pp. $x-x x$; confused bibliography at pp. vi-ix.

Furcy-Chatelain, Le Pan-Américanisme et l'Équilibre Américain. (Paris, Saint-Amand, 1897)

A continuous indictment of the "perverse doctrine" of the United States. Little history and much rhetoric.

García-Calderón, Francisco, Les Democraties Latines de l'Amérique. (Paris, Flammarion, 1912)

Study of origins, the Latin American countries by groups; political philosophies; much on attitude of the United States and of Asia. Well studied. Map.

Griffis, William Elliot, America in the East; a Glance at Our History, Prospects, Problems, and Duties in the Pacific Ocean. (N. Y., Barnes, 1899)

General discussion of Pacific and Asiatic interests.

Hull, William IsaAc, The Monroe Doctrine: National or International? The Problem and its Solution. (N. Y., etc., Putnam, 1915)

Kasson, John Adam, The Evolution of the Constitution of the United 、 States and a History of the Monroe Doctrine. (Boston, etc., Houghton, Mifflin, 1904)

At pp. 221-273 a sketchy "History of the Monroe Doctrine", with a general defense of the principle.

Keasby, Lindley Miller, The Nicaragua Canal and the Monroe Doctrine; a Political History of Isthmus Transit with Special Reference to the Nicaragua Canal Project and the Attitude of the United States Government Thereto. (N. Y., etc., Putnam, 1896)

A plea for the Nicaragua route, and for a vigorous Monroe Doctrine. See especially chs. vi, $\mathrm{x}$, xviii, xxiv. Contains maps. Out of date.

Kraus, Herbert, Die Monroedoktrin in ihren Beziehungen zur amerikanischen Diplomatie und zum Völkerrecht. (Berlin, Guttentag, 1913)

The most careful and elaborate work as yet published on the Monroe Doctrine. Based on studies in the United States and system- 
atic use and digesting of the great mass of materials. Aims to furnish a safe background of facts and occurrences, followed by a discussion of the international applications of the Monroe Doctrine. Avoids predictions and distinction of motives.

The work is highly analyzed and very convenient for the user, with appendix of exact dates and a brief appendix of selected documents. A full bibliography and a great number of bibliographical notes.

Leavitt, Joshua, The Monroe Doctrine. (N. Y., Tousey, 1863)

$\checkmark$ Pamphlet (50 pp.). Very American and Protestant.

MacCorkle, William Alexander, The Monroe Doctrine in its Relation to the Republic of Haiti. (N. Y., Neale, 1915)

Patouillet, Joseph, L'Impérialisme Américain. (Paris, Rousseau, 1904)

In Library of Congress.

Paxson, Frederic Logan, The Independence of the South American Republics: a Study in Recognition and Foreign Policy. (Phila., Ferris \& Leach, 1903)

Careful study of recognition as a part of the Monroe discussion.

Pereyra, Carlos, La Doctrina de Monroe; el Destino Manifiesto y el Imperialismo. (Méjico, Ballescá, 1908)

Brief book by a Mexican. Substantially a series of disconnected essays. Critical of the United States.

Pérez Triana, Santiago, La Doctrina Drago, con una Advertencia Preliminar, y una Introduction de W. T. Stead. (London, Wertheimer, Lea y Cia ....)

Collection of documents made by an Argentine.

Petin, Hector, Les États-Unis et la Doctrine de Monroe. (Paris, Rousseau, 1900)

A systematic discussion of the whole field with brief accounts of many interesting episodes including specific questions. Charges the United States with schemes of conquests of all America. Poor bibliography of books and periodicals.

The fullest and most important work in French.

Phelps, Edward John, America and Europe; a Study of International Relations. (N. Y., Putnam, 1896)

Part II is on "The Monroe Doctrine." 
Reddaway William Fiddian, The Monroe Doctrine. (Cambridge Univ. Press, 1898)

A searching and original book - especially valuable on origins. Best book by an Englishman.

Ribet, Joseph, Le Vol de l'Aigle de Monroë à Roosevelt. (Paris, Flammarion, 1905)

In Library of Congress.

Solar, Alberto Del, La Doctrina de Monroe y la America Latina. (Buenos Aires, Penser, 1898)

Pamphlet warmly denouncing the greed of the United States.

Tucker, George, Fox, The Monroe Doctrine; a Concise History of its Origin and Growth. (Boston, Reed, 1885)

Brief and cogent book - chiefly history up to 1871 ; much weight but now almost out of date.

Usher, Roland Greene, Pan-Americanism; a Forecast of the Inevitable Clash between the United States and Europe's Victor. (N. Y., Century, 1915)

This writer is freely criticized in the text. He adds nothing to the knowledge of the subject.

\section{PRINTED SOURCES OF THE MONROE DOCTRINE}

The ultimate materials of the Monroe Doctrine are as follows ;

(1) The published announcements of Presidents and other members of the government of the United States, which can be found in various public documents and in the set of presidential messages.

(2) Memoirs of statesmen. A select list may be found in Channing, Hart, and Turner, Guide to American History, § 47. Lists of the collected works of some of the statesmen in the same volume, $\S 46$. Several presidents, especially John Quincy Adams, James K. Polk and Theodore Roosevelt, have written first hand accounts of their own connection with the diplomacy of their times.

(3) Collections of diplomatic materials, which contain despatches of Secretaries of State and foreign ministers and the correspondence of public men. 
Adams, John Quincy, Memoirs: comprising Portions of his Diary from 1795 to 1848 . (12 vols., Phila., Lippincott, 1874-1877)

Contains first-hand material on Monroe's Doctrine and the Panama Congress of 1826 .

Hart, Albert Bushnell, and Channing, Edward, American History Leaflets. (N. Y., Lovell, now Simmons, 1892-1910)

No. 4 (1892) is made up of extracts bearing on The Monroe Doctrine.

Lowrie, Walter, and Clarke, Matthew St. Clatr (Editors), American State Papers: Documents, Legislative and Executive, of the Congress of the United States. Class I, Foreign Relations. (6 vols., Washington, Gales and Seaton, 1832-59)

Commonly quoted as "American State Papers, Foreign." A valuable set, well arranged and indexed.

Malloy, William M., Treaties, Conventions, International Acts, Protocols and Agreements between the United States of America and other Powers (1776-1909). (2 vols., Washington, Gov. Printing Office, 1910) (This is Senate Docs., 61 Cong. 2 sess. No. 357)

Supplementary volume, edited by Garfield Charles (Washington, Gov. Printing Office, 1913), comes down to March 4, 1913. (This is Senate Docs., 62 Cong. 3 sess. No. 1063)

This is the standard edition of the treaties of the United States.

Moore, John BASseTt (Editor), Digest of International Law as embodied ... especially in Documents ... of the United States. (8 vols., Washington, Gov. Printing Office, 1906) (This is House Docs., 56 Cong. 2 sess. No. 551)

Very full "General Index" in Vol. VIII. See Arts. : "Monroe Doctrine" and titles concerning controversies and International claims. See also Latin-American States by name.

Abounds in extracts from State papers and official correspondence on all fields of American policy. This is the best collection of material on Latin-American relations.

Polk, James Knox, The Diary of James K. Polk during his Presidency, 1845 to 1849 , now first printed from the Original Manuscript . . edited and annotated by Milo Milton Quaife, with an Introduction by Andrew Cunningham McLaughlin. (4 vols., Chicago, McClurg, 1910)

Annotations very slight. Poor index. Frank statement of influences and motives. 
Richardson, James Daniel (Editor), Compilation of the Messages and Papers of the President (1789-1897). (10 vols., Washington, Gov. Printing Office, 1896-1899) (This is House Mis. Docs., 53 Cong. 2 sess. No. 210, also published separately)

Contains text of all presidential statements of American policy, so far as embodied in messages to Congress. Well indexed. Vol. X. contains McKinley's messages in the Spanish War.

Roosevelt, Theodore, Theodore Roosevelt: an Autobiography. (N. Y., Macmillan, 1913)

Ch. xiv is upon "The Monroe Doctrine and the Panama Canal." It is a convenient statement of the ex-President's policy in Santo Domingo and Panama. An Appendix, pp. 572-574, contains a proposed message to Congress.

Rush, Richard, Memoranda of a Residence at the Court of London (1819-1825). (Phila., Lea and Blanchard, 1845)

First-hand account of the transaction with Canning at the time of Monroe message of 1823.

United States, Compilation of Reports of Committee on Foreign Relations, United States Senate (1789-1901). (8 vols., Washington, Gov. Printing Office, 1901) (This is Senate Docs., 56 Cong. 2 sess. No. 231)

Convenient assemblage of reports many of which bear on the Monroe Doctrine. See Index, countries by name.

United States, Papers relating to the Foreign Relations of the United States. - From 1861 to 1868 designated as Diplomatic Correspondence, since 1870, as Foreign Relations. (Washington, Gov. Printing Office, 1861-date)

Index Volume described above.

Wharton, Francis (Editor), Digest of the International Law of the United States, taken from Documents issued by Presidents and Secretaries of State, and from Decisions of Federal Courts, and Opinions of Attorneys-General. (3 vols., Washington, Gov. Printing Office, $2 \mathrm{~d}$ ed., 1886) (This is Senate Mis. Docs., 49 Cong. 1 sess. No. 162, also published separately, 1887)

Most of the matter is included in Moore's Digest. 



\section{INDEX}

\section{(INCLUDING THE BIBLIOGRAPHY)}

A B C combination, 251, 252; and joint action with United States, 256; and Mexico, 335 ; American Doctrine outgrown by, 354 ; and maintenance of Doctrine, 381,382 ; and peace, 391.

Accessory Transit Company, 129. Adams, Charles $\mathrm{K}$., on progressiveness of American Doctrine, 301.

Adams, John, on Doctrine of Isolation, 9, 13; and Miranda, 25.

Adams, John Q., on Doctrine of Two Spheres, 16; problems as Secretary of State, 31, 301 ; Florida negotiations, 34 ; distrust of Latin America, 34, 35; on Holy Alliance, 44; and Russian elaims in Northwest, 49 ; on European colonization in America, 49, $50,72,73$; and European intervention in Latin America, $51,62-64$; and framing of Monroe Doctrine, authorship, $57,64,65,302$; on Canning's proposal of joint declaration, 59,60 ; on European political systems, $60,61,74$; and Cuba, transfer of territory, 78, 79, 91,310 ; and hegemony, 83, 376 ; policy of protection of Latin America, Panama Congress, $89,94,96,364$; interpretation of Monroe Doctrine (1826), 91 ; on Polk's doctrine, 115 ; Memoirs, 420.

Africa, interest of United States, 212.

Aix-la-Chapelle, Congress of (1818), 45.
Alaska, Russian claims, ukase of 1821,17 ; outside Monroe Doctrine, 77; annexation, 155; status, 211 ; refusal of ports to Canada, 220.

Alexander I of Russia, and Holy Alliance, 44.

Algeciras, Congress at, 212, 275, 281.

Algeria, French designs on, 41.

Aliens. See Foreigners.

Alvarez, Alejandro, on Creoles, 22 ; on disturbances, 38 ; on example of United States, 319 ; Droit International Américain, 414.

American Academy, Foreign Policy of United States, 414; International Relations, 414; Pan-American Conferences, 415; Progress in Latin A merica, 415; United States as.a World Power, 415.

American Doctrine, definitions, 2 , 162, 349-352; Fish's doctrine, 165, 166; Olney's exposition, 194-196 ; Cleveland's view, 198, 199; Roosevelt's interpretation, 225-227, 233; and control of Dominican customs, 232; extension to Asiatic powers, 235 ; Root's interpretation, 235-238, 242 ; rights independent of, 236 ; unilateral, $237,243,354$; false conceptions, 237 ; geographical extent, question of limitation, 237, 305, 306; no formulation possible, 241,242 ; and action of individuals, 257 ; and enforcement of claims, 258; German views, 277, 278; and European War, 281; and retention of 
American Doctrine-continued

Philippines, 291 ; Japanese test, 296,297 ; necessity of change and progressiveness, 299-301, 309 , 367; widening of field, 301 ; chief exponents of changed points of view, 302 ; changes in American territorial conditions (1823-1915), 302-305; and peace, 309, 355, $360-362,385,386$; and international law, 316 ; European attitude, 316 ; and inferior states, 321, 322; actuality of protection of Latin America, 325 , 326; basis of strength, 326 ; commercial phase, 337-339, $362-364$; as a coverall, 350, 353 ; modern objections, 354, 355 ; uneven application, 354 ; outgrown by various LatinAmerican states, 354 ; no legal or popular sanction, 355 ; and militarism, 355 ; as a universal principle, 356,401 ; dislike of Latin America, 357; question of extra-American support, 359; enforcement of responsibility of Latin America, 364, 365; need of simplicity, 365; paramount interest as phrase, 366 ; necessary elements of future, 366-368; future, not law, 367. See also Monroe Doctrine and cross references under it.

American Journal of Internalional Law, 408.

American Revolution, influence on Americanism, 7; effect on Europe, 7, 8; and Latin America, 7, 8, 24.

American Year Book, 408.

Americans, colonists as Englishmen, 6 ; influence of American Revolution, 7.

Annexations by United States, first inroads on Latin America, $14,15,34$; rival claims on the Pacific, 17, 18; ambitions (1823), 18; Jefferson's denial of desire for West Indies (1791), 25 ; Channing's policy to check, 53,59 ; and American Doctrine, $108,109,113,141,164,255$, $352,355,366,369,401$; Polk's policy, 112, 113, 120,

\section{Annexations - continued}

127 ; Polk on European interference, 114 ; Douglas's policy, 133 ; to protect domestic institutions, 135; temporary, of guano islands, 136, 137; Seward's policy, 151; Johnson's policy, 159; as basis of American diplomacy (1845-69), 159; influence of "coast-line" theory of Isthmian Canal, 171, 260, 384 ; Cleveland's opposition, 183,185 ; results of SpanishAmerican War, 210; Roosevelt's and Wilson's disclaimer of desire, 225, 226, 239, 240, 308 ; results, 304 ; spirit of expansion, 309,353 ; and Mexican problem, 335. See also Colonization ; ProtectoRates; Transfer of TERrITORY; and annexed portions by name.

Annual Register, 408.

Antokoletz, Daniel, Doctrine de Monroe, 415.

Appletons' Annuai Cyclopæedia, 408.

Arbitration, and hegemony in America, 177; plan of PanAmerican Congresses, 189, 190, 228; of claims, 261; Hague Convention on, for contract debts, 266; and maintenance of American Doctrine, 383, 384. See also HAgUE TRIBUNAL.

Arenas y Loayza, Carlos, on source of Monroe Doctrine, 65. Argentina (Buenos Ayres), English occupation, 26 ; proclaims independence, 30 ; recognized by United States, 34 ; prosperous development, 103 ; and Falkland Islands, 105, 312, 325 ; French-British blockades, 106, 142; immigration, 247; future, 248; stability of government, 249, 252; federal government, 250 . See also A B C; Latin America ; Pan-Americanism.

Aristocracy, governmental, in Latin America, 248, 375.

Arthur, Chester A., trade commission to Latin America, 187. 
Asia, American policy in, 211. See also China; Japan.

Asquith, Herbert H., on policy towards Mexico, 334.

Asylum, right of, in Latin America, 191, 322-324.

Austria, reception of Monroe Doctrine, 85. See also HoLY Alliance.

Babcock, Orville E., and Santo Domingo, 151.

Balmaceda, José M., asylum question, 323, 324.

Baltimore, U.S.S., Valparaiso incident, 191.

Barral-Montferrat, Marquis de, on Monroe Doctrine, 353; De Monroë à Roosevelt, 415.

Barrett, John, on Pan-Americanism as substituted for Monroe Doctrine, 379, 380; Pan American Union, 410.

Barrundia case, 322, 323.

Bay Islands controversy, 125, 312.

Bayard, Thomas F., on Falkland Islands controversy, 105; as Secretary of State, 184; on United States as protector, 184; call of Pan-American Congress, 189 ; on VenezuelaGuiana boundary, 193.

Beard, C. A., Contemporary American History, 410.

Beaumarchais, Maurice D. de, on Monroe Doctrine, 352; Doctrine de Monroē, 415.

Belize. See British Honduras.

Belligerency, recognition of LatinAmerican, 33.

Benham, Andrew E. K., and Brazilian naval insurrection, 192.

Benton, E. J., Spanish-American War, 410.

Bernhardi, Friedrich von, doctrine of force, 390 .

Bernstorff, Count von, on Germany and South America, 279.

Big Stick, Doctrine of the, 318 . See also Police Power.

Bigelow, John, and Seward's neglect of Monroe Doctrine, 149.

Bigelow, John, Jr., American Policy, 415.
Bingham, Hiram, on Latin-American distrust of Monroe Doctrine, 254; on the Doctrine, 350 ; Monroe Doctrine, 415.

Bismarck, Prince von, on Monroe Doctrine, 275, 278.

Blaine, James G., as Secretary of State, 162, 172, 184; Canal policy, 172-176, 341 ; on political system, 173; Pan-American Congress and hegemony, $176-178,182,189$; and intervention in Chilean-Peruvian War, 178-180; and reciprocity, 187,188 ; as exponent of American Doctrine, 302 ; failure of policy, 377.

Blakeslee, G. H., (ed.) China, 416; (ed.) Japan, 416; (ed.) Latin America, 416.

Bland, Theodoric, agent to Spanish America, 33.

Bolivar, Simon, and first Venezuelan revolt, 27; in Peru, 30 ; and San Martin, 30; character, 30 ; and Pan-LatinAmericanism, 37; on Monroe Doctrine, 86; and Panama Congress, 93; Clay's warning against ambitious designs, 98 . Bolivia, origin, 101. See also Latin America; Pan-AmerICANISM.

Bonin Islands, claims to, 287.

Bourne, Edward G., on Philippines and Monroe Doctrine, 282.

Boxer Rising, United States participation in joint expedition, 211.

Brazil, Portuguese royal family in, 26; independence, 31; recognized by United States, 34; offers alliance to United States, 87; British blockade (1863), 152; naval insurrection, 192; immigration, 247; future, 248 ; stability of government, 249, 252; federal government, 250; Germans in, 273, 307; and debt of Uruguay, 324. See also A B C; Latin America; Pan-AmerICANISM.

British Guiana. See VenezuelaGuIANa boUndary. 
British Honduras (Belize), development, 117, 118 ; and Clayton-Bulwer Treaty, 125; attempts to enlarge, 312 .

Brougham, Lord, on Monroe Doctrine, 84.

Brown, Philip M., on Monroe Doctrine, 351 ; on inter-American law, 378.

Bryan, William J., and India, 313 ; and Santo Domingo, 330; and Nicaragua, 332; policy, 377 ; and peace, 386 .

Buchanan, James, and Panama Congress, 95 ; and Cuba, 120, 138; on Monroe Doctrine and Clayton-Bulwer Treaty, 126 ; as President, 128; Ostend Manifesto, 134; Mexican policy, 138 ; and Monroe Doctrine, 141 ; failure of American policy, 377.

Bülow, Prince von, on Venezuela episode, 275, 276.

Buenos Ayres, Pan-American Congress, 229, 253 . See also Argentina.

Bullock, William, work on Mexico, 35.

Bulwer, Sir Henry, Clayton-Bulwer Treaty, 124, 125.

Burlingame, Anson, and China, 283.

Calderón. See Garcia CalDERón.

Calhoun, John C., and joint declaration with England against intervention, 59,62 , 63 ; on colonization clause of Monroe Doctrine, 73; protest on British abolition propaganda in Texas, 109, 110.

California, Russian posts, 17 ; desire of United States for, 108,113 ; spirit of independence after annexation, 130.

Callahan, James M., on Monroe Doctrine, 351 ; American Relations in the Pacific, 410; Cuba, 411.

Calvo, Carlos, resolution on, 228. See also Calvo Doctrine.

Calvo Doctrine, 190, 262-264; attitude of United States, 264; Pan-American Congress on (1906), 264; and sovereignty,
Calvo Doctrine - continued 321 ; logical foundation, 364 ; justice, 365 .

Canada, Jefferson's advocacy of annexation, 27; and field of American Doctrine, 77, 306 ; spirit of annexation, 154; Dominion and Monroe Doctrine, 154, 155, 158; as American, 270; Monroe Doctrine and participation in European War, 280, 281; relations with United States, 311; and reciprocity, 347 .

Canning, George, view of America, 49; proposal of joint declaration on Latin America, 52-54; and French disclaimer, 54 ; debt of Monroe Doctrine to, $57,66,84$; debate of Monroe's Cabinet on proposals, Adams on their purpose, 59, 60 ; recognizes Latin-American states, 85,86 ; and Panama Congress, 97; opposition to leadership of United States, 97.

Cannon, Lee R., executed in Nicaragua, 331 .

Capella y Pons, F., on Monroe Doctrine, 353; Monroïsme, 416.

Caribbean Sea, and defense of Canal, 225, 237; paramount interest, 351.

Cass, Lewis, and Hungary, 122; as Secretary of State, 128; interpretation of Monroe Doctrine, 132, 134, 141; and Mexico, 138; on joint expedition against Mexico, 147; on right to open commercial highways, 218.

Castlereagh, Lord, and Holy Alliance, 44; and Latin America, 48.

Castro, Cipriano, as dictator, 249. Caylus, Ernest, Doctrine Monroë, 416.

Central America, temporary union, 37; Walker's filibustering, 137; public debts and protectorates, $234,260,335$; interventions by United States, 330,331 ; influence of Canal on relations, 346. See also Latin America; Pan-AmerICANISM; and states by name. 
Central American Confederation, 102.

Céspedes, J. M., Doctrina de Monroe, 416.

Chadwick, French E., on LatinAmerican race, 23 ; on maintenance of Monroe Doctrine, 374; United States and Spain, 411.

Channing, E., Guide, 406 ; American History Leaflets, 420.

Charles V of Germany, grants in South America, 270.

Charles IV of Spain, abdicates, 26.

Chase, Salmon P., on Seward's Mexican policy, 150.

Chateaubriand, Vicomte de, on Monroe Doctrine, 84.

Chester, Colby M., on Monroe Doctrine, 349.

Chile, independence, 30 ; recognized by United States, 34; Spanish War, 152; Peruvian War, intervention of United States, 178-180; difficulties with United States (1892), 191,192 ; stability of government, 249, 252; revolt against Balmaceda, question of asylum, 323. See also A B C; Latin America; Pan-Americanism.

China, German plans, 274 ; first American relations, 283 ; American naval expeditions, 289; extraterritoriality, 289; character of American influence, 280, 292; European designs and intervention, 292; Hay's Open Door, 293; effect of European War on balance in, 294 ; understanding of Japan and United States on (1908), 294, 295; Knox's note on Manchurian railways, 295, 296 ; Japanese extraterritoriality, 297; attitude of Japan, 297,298 ; as future great power, 314 .

Chincha Islands, seizure by Spain, 152.

Christiancy, Isaac P., and Chilean Peruvian War, 178.

Claims against Latin America, origin of first, 32 ; arising from anarchy, 103; and proposed
Claims - continued

American intervention in Mexico (1859), 138; and European expedition against Mexico, 143; proposed American guaranty of Mexican debt (1861), 148; Pan-American Congresses on pecuniary, 190, 228 ; intervention in Venezuela, $230,231,275-277,317$; intervention and priority in settlement, 231, 317; American management of Santo Domingo and Nicaragua customs to pay, 231-233, 329-333 ; no protection against just, but no seizure of territory to compel settlement, 233, 234, 237, 241, 258; mediation of United States, 237,260 ; Wilson on danger in concessions, 239; and revolution, 259, 268; character of public debts, 260; policy of United States towards claims of her own citizens, 261, 265, 266 ; false, 261, 262; Calvo Doctrine on, 262-264; Drago Doctrine on, 264, 265; Hague Convention on, 266; United States cases before Hague Tribunal, 267; inadequacy of Drago Doctrine, 267, 268; logical foundation of Calvo Doctrine, 364; protectorates as solution, 365. See also Foreigners; Intervention.

Clarke, M. S. C., American State Papers, Foreign, 420.

Clay, Henry, and recognition of Latin-American states, 33, 34, 57 ; resolution on intervention $(1824), 89$; policy of protection of Latin America, 89, 94; and joint expedition to Cuba, 91 ; instructions to commissioners to Panama Congress, 96; and failure of Panama Congress, 97 ; to Bolivar on ambitious designs, 98; and Kossuth, 123; and hegemony in America, 176.

Clayton, John M., Clayton-Bulwer Treaty, 124; on Hawaii, 285.

Clayton-Bulwer Treaty, provisions, 124; and Monroe Doc- 
Clayton-Bulwer Treaty - cont. trine, 125-127, 140; defect, 127 ; Seward's treaties contrary to, 158; Fish's opposing policy, 168; Blaine's opposing policy, 172-174; Granville's support, 174-176; and Zavala draft treaty, 176; as a drag, 181 ; abrogated, 215, 221, 341, 342.

Clergy, support of Holy Alliance, 46.

Cleveland, Grover, as diplomatist, 183,373 ; opposes annexations, 183, 185, 287; Canal policy, 185 ; and Latin-American commerce, 187; call of PanAmerican Congress, 189; and Venezuela-Guiana boundary, occasion for interference, 194, 198, 199, 202-204; and Cuba, 207; on Congo Conference and Two Spheres, 212; on Liberia, 288.

Coaling stations. See Naval and COALING STATIONS.

Cochrane, Lord, in Chile, 30.

Collection of debts. See Claims.

Colombia, recognized by United States, 34; proposed Cuban expedition, 91 ; split of original, 102 ; treaty of $1846,117-119$, 219 ; draft canal treaties (1869), 157 ; (1870), 168; (1903), rejection of it, 216, 217; French concession, 169; and recognition of Panama, attempts to placate, $220,324,333,346$; Yankee bugaboo, 254. See also IsthMian Canal; Latin America; Pan-Americanism. Colonization of America by European powers, opposition to, in original Monroe Doctrine, 4, $67,71-74,80,351$; Adams on Russians on Northwest Coast, 49,50 ; doctrine not applicable to inter-American relations, 72 ; or to existing colonies, 72, 90, 134, 352; Russian treaty (1824), 88; Clay's instructions, 90; in call of Panama Congress, 93; Polk's doctrine, 114, 115; no voluntary union of American state with European one, 115, 164, 311; British in Central
Colonization - continued

America, 119, 312; and Isthmian Canal question, 125, 126 ; Cass's resolution (1853), 132 ; redress of grievances and collection of debts not to result in, $147,233,264,276,277$; Olney on, his opposition to permanent colonies, 195, 196; Salisbury on, 200 ; recolonizing of Cuba, 209; Roosevelt on, 225 ; Drago on spirit of colonization, 265; present status, 269 ; danger from Germany, 278-281; and Pacific Coast, 282 ; Webster on, in Hawaii, 284; prevented in Hawaii, 284,285 ; and retention of Philippines, 290, 291; efforts and decrease since 1823, 305, 311,312 ; British colonies alone of present significance, 306, 308 ; necessity of doctrine to United States, 358, 369, 397; Sir Edward Grey on, 361 . See also Annexations; TransFER OF TERRITOKY.

Commerce, restrictions on colonial, 20 ; of colonial Spanish America, 21; early Latin-American, prized, 35 ; as element of American Doctrine, $62,77,94,225,401$; question of British ascendancy in America $(1846), 118,119$; rise of influence on diplomacy, 162 ; and Fish's policy, 165, 166; development of Latin-American, and diplomacy, 187, 337339 ; reciprocity, 187-189, 339 ; shipping and subsidy in LatinAmerican, 189, 340; measures in Pan-American Congresses, 189 ; right to keep great highways open, $217-219$; present condition of Latin-American, 248 ; development of Asian, 282 ; Open Door in China, 293 ; Japanese understanding, 294 ; Knox's note on Manchurian railways, 295 ; development of European relations, 314; equal use of Isthmian Canal, 343; Canal and coast trade, 344; and trade with Asia, 345; and 
Commerce - continued

Latin-American trade, 345, 346 ; question of possible alliance between American states, 347, 348; and protectorates, 362-364.

Concessions, Wilson and Page on, in Latin America, 239-241.

Confederate States, and Mexico, 148.

Congo, United States and Conference, 212.

Congress, attempts to formulate Monroe Doctrine, 89, 115, 132 ; and French in Mexico, 150; on formation of Dominion of Canada, 155; Magdalena Bay episode, 235; Platt Amendment, 327 ; and American Doctrine, 355.

Consolidation, spirit of governmental, 314.

Constellation, U.S.S., in Hawaii, 284.

Coolidge, A. C., United States as a World Power, 411.

Corwin, Thomas, Mexican mission, 144, 148.

Creoles, character, 22, 23.

Crichfield, G. W., American Supremacy, 416.

Cuba, Jefferson's advocacy of annexation, 27, 29; influence on formation of Monroe Doctrine, 78, 79 ; proposed Colombian-Mexican expedition to free, 91; American protest on supposed French designs (1825), 91; and Panama Congress, 93; Canning's opposition to change, 97 ; protests against transfer (1827-44), 106108 ; protest against emancipation (1829), 107 ; Polk's designs on, his attempt to purchase, 113, 121; filibustering, 121 ; proposed joint guaranty (1852), 130; Cass's resolution against transfer (1853), 132 ; 'Pierce's designs on, 134; Ostend Manifesto, 134, 135; no danger of transfer, 141 ; Seward's desire for, 145; first insurrection, policy of United States, 163, 166-168, 181; second insurrection, 207 ; question of American intervention,
Cuba-continued 207-209; Teller Resolution against annexation, 209; and origin of no-transfer-of-territory doctrine, 310 ; protectorate, 327. See also West Indies.

Customs, management by United States of Latin-American, to forestall interventions, 231-233, 329-333. See also TARIFF.

Cyclopedia of American Government, 409.

Davis, JefFerson, as member of Cabinet, 128.

Dawkins, - British commissioner to Panama Congress, 97.

Debts. See Claims.

Declaration of Paris, United States and, 139.

Democracy, advance in Europe, 312 ; and War of 1914, 313. See also Political system; Republican government.

Denmark, Sound dues treaty, 139 ; West Indian islands, 151.

Dennison, — in Japan, 290.

Dependencies, glamour, 362. See also Colonization; ProtecTORATES.

Dernburg, Bernhard, on Germany and America, 280; on Canada, 280.

Dewey, George, in Philippines, 210.

Diaz, Porfirio, as dictator, 245 ; on Monroe Doctrine, 253 ; intervention in Central America, 330.

Dickinson-Ayon Treaty, 157.

Diedrichs, Admiral, at Manila, 210.

Dingley Tariff, reciprocity, 188, $189,339$.

Diplomacy, success of American, and overconfidence, 387-389.

Dollar diplomacy, 234; effect on German opinion, 278; in Nicaragua, 332, 333.

Douglas, Stephen A., on extent of Monroe Doctrine, 76; foreign policy, 129 ; as chauvinistic annexationist, 133, 141.

Drago, Luis M., on Monroe Doctrine, 253; doctrine on collection of debts, 264, 265. 
Drago Doctrine, 264, 265; attitude of United States, 265, 266, 364; Hague Convention on, 266 ; inadequacy, $267,268$.

Duncan, Silas, and Falkland Islands, 105.

Dunning, J. C., Monroedoktrin, 416.

ECONOMIC THEORY OF HISTORY, inadequacy, 362.

Ecuador, formation, 102; debt, 259 , 320. See also LATIN America; Pan-Americanism.

Edginton, Thomas B., on Monroe Doctrine and the Pacifie, 283; on inferior nations,231; Monroe Doctrine, 416.

Egan, Patrick, and right of asylum, 191, 323, 324 .

Encyclopxedia Britannica, 409.

English American colonies, origin, 4 ; contrast with Latin America, 5, 6; colonists as Englishmen, 6.

Étoile, on Monroe Doctrine, 84.

Europe, consolidation and future great powers, 314 .

European War, main object, 275 ; Germany and expansion in America, 279-281; and American Doctrine, 281; possible effect on China, Japan's hegemony, 294, 298; and democracy, 313; lessons as to belief in force, 389-391, 397, 402.

Evarts, William M., phrases Paramount Interest, 162 ; as Secretary of State, 162; Isthmian Canal policy, 170.

Everett, Edward, and Cuba, 106, 131.

Exploration, period of European neglect, 3.

Extraterritoriality, in Hawaii, 285 ; in China and Japan, 289 ; Japanese in China, 297.

Falkland Islands, controversy, $105,312,325$.

Farewell Address, on isolation, $11,12$.

Federal government in Latin America, 250, 376.

Fenians, raid on Canada, 154.
Ferdinand VII of Spain, renounces claim, 26 ; reactionary rule, 30 ; revolt against, 47 ; asks aid to recover American colonies, 48.

Filibustering, during LatinAmerican revolutions, 32 ; Cuban, 121; Walker's, 137. Fish, C. R., American Diplomacy, 411.

Fish, Hamilton, and Santo Domingo, 151; and SpanishChilean War, 152; as Secretary of State, 162; and Cuba, 163, 167, 181; American Doctrine, 165, 166; Canal policy, 168, 341 ; and commerce, 337 .

Flores, Juan J., seeks aid from Spain, 102.

Florida, annexation, 16 ; negotiations and recognition of Spanish American states, 34 ; Jackson's invasion, 325.

Forbes, John M., agent to Spanish America, 34.

Force, doctrine of, and European War, 389-391, 397, 402. See also PEACE.

Foreigners in Latin America, rights, $190,230,258,259$; difficulties, 257; claims for damages by revolutionists, 259 ; Calvo Doctrine on rights, 263; Pan-American Congress on rights, 264 ; Webster on Americans in Hawaii, 285 ; need of inter-American law on status, 378.

Forey, Élie F., Mexican expedition, 146.

Forsyth, John, and Cuba, 107.

Fortifications of Isthmian Canal, 343.

Foster, John W., on protectorate in Hawaii, 284; and China, 290; American Diplomacy, 411.

France, and Spanish Louisiana, 15; desire for colonies, 41; designs on Latin America, 41; reception of Monroe Doctrine, 84; and Cuba (1825), 91; blockades of Buenos Ayres, 106; Napoleon III, 117; and joint guaranty in Cuba, 130; Mexican expedition, 146, 149, 153,312 ; proposed joint inter- 


\section{France-continued}

vention in Chilean-Peruvian War, 179; present attitude toward Latin America, 269; and Hawaii, 285 ; and Isthmian Canal, 342. See also European War; Holy Alliance.

Frankfort Parliament, 117.

Frelinghuysen, Frederick T., Canal policy, 176 ; on force and application of Monroe Doctrine, 176; and hegemony, 180 ; on Liberia, 288; on transfer of territory from republic to monarehy, 324 .

French Revolution, effect on Latin America, 24.

Fried, A. H., Pan Amerika, 417.

Fullam, William F., at Ceiba, 331. Furcy-Chatelain, Pan Américanisme, 417.

Gadsden Purchase, 135.

Garcia-Calderon, Francisco, on Monroe Doctrine, 253; Democraties Latines, 417.

García-Mérou, Martín, Diplomacia, 411.

Garfield, James A., Canal policy, 172.

Genêt, Edmond C., and American neutrality, 11.

Gentz, Friedrich von, on Monroe Doctrine, 85.

Geographical extent, of original Monroe Doctrine, 76, 77, 140 ; suggested limitation, 237, 306 ; territorial changes of field (1823-1915), 302-305; present field, 305 .

Germans, in South America, 247, 273,307 ; in United States, 272.

Germany, and Samoa, 186, 288; coercion on Venezuela (1902), $230,231,275-277,317$; and colonization of America, 270, 271 ; European colonization, 271 ; attitude of Germans in Brazil towards Fatherland, 273, 307 ; colonial efforts, 274, 275; and Spanish-American War, 277 ; Emperor William on United States, 277; views of Monroe Doctrine, 278 ; danger to America from, 278-281;
Germany - continued

as future great power, 314. See also EUROPEAN WAR.

Gilman, D. C., James Monroe, 406.

Girard, Stephen, West Indian trade, 36.

Government. See Political SYSTEM ; REPUBLICAN GOVERNMENT.

Graham, John, agent to Spanish America, 33.

Grant, Ulysses S., and Santo Domingo, 152; and Cuba, 163, 167 ; interpretation of Monroe Doctrine, 163-165.

Granville, Earl, and ClaytonBulwer Treaty, 173-175.

Great Britain, colonizing rivalry in America, 4; Nootka Sound Convention, 24 ; Spanish-American expeditions (1806), 26 ; relations with Spain, 41; attitude toward Spanish America (1814), 42; and Holy Alliance, $44,45,56$; and intervention in Latin America (1818), 48; Canning's Latin-American policy, $49,52-54,58-60$; and formulation of 'Monroe Doctrine, 57, 66; reception of Doctrine, 84; recognition of Latin-American states, 85,86 ; and Falkland Islands, 105, 312 ; blockade of Buenos Ayres, 106 ; and Cuba (1827-44), 106-108; and slavery in Texas, 109; Oregon controversy, 113; claims in Central America, $117-119,141,312,341$; as an American power, 126, 140, 175, 197, 201, 269, 306, 308; and joint guaranty of Cuba, 130 ; joint expedition against Mexico, 146; blockade of Rio, 152; and Suez Canal, 174, 175, 342; proposed joint intervention in Chilean-Peruvian War, 179; and Samoa, 186, 288; and Spanish-American War, 214; coercion on Venezuela (1902), $230,231,276,317$; and Hawaii, 284,285 ; Knox's note on Manchurian railways, 295, 296 ; as future great power, 314 ; naval power and defense of 
Great Britain - continued

Latin America, 359; American diplomatic success over, 387. See also Clayton-Bulwer Treaty; EUROpean War; Venezdela-GUIana BodNDARY. Greek revolt, and Holy Alliance, 47; United States and, 58.

Grey,. Sir Edward, on Monroe Doctrine, 361.

Greytown, bombardment, 325.

Grievances, recognized right to redress, 147. See also Cuarms.

Griffis, W. E., America in the East, 417.

Groce, Leonard, executed in Nicaragua, 331 .

Guam, annexation, 210.

Guano islands, temporary American title, 136, 137, 287.

Guatemala, recognized by United States, 34; Barrundia case, 322, 323. See also Central America; Latin America; Pan-Americanism.

Guzman Blanco, Antonio, as dictator, 249.

Hague Conferences, and American Doctrine, 213 ; LatinAmerican states at second, 229 ; on collection of debts, 266; failure to prevent wars, 383.

Hague Tribunal, on Venezuelan episode, 231, 317; United States cases before, 267.

Haiti, and original Monroe Doctrine, 79; conditions (1861), 142 ; recognition, 145 ; Pelletier case, 262 ; probable protectorate, 335. See also West INDIES.

Hamilton, Alexander, on United States as arbiter of Europe, 14 ; on Miranda's scheme, 25; on probable war with Spain, 25.

Harrison, Benjamin, Canal policy, 186 ; and Chile, 191.

Hart, A. B., Guide, 406; (ed.) American Nation, 406, 410; Foundations, 407, 411; Manual, 407 ; American History Leaflets, 420.

Hasse, A. R., Index to Foreign Relations, 407.

Hate, as international factor, 362 .
Hawaii, first attempts at annexation, 108, 136, 285-287; Cleveland prevents annexation, 185 ; annexation, 210; status, 211, 287 ; development of American interest, 282; Webster on paramount interest, 283; Tyler on protection, 284; European designs on, prevented, 284, 285; reciprocity, 287; Wilson on responsibility to, 291 .

Hay, John, and reservation in Hague Convention, 213; as Secretary of State, 214, 224; abrogation of Clayton-Bulwer Treaty, 214, 215; draft Canal treaty with Colombia, 216; and recognition of Republic of Panama, 217; Canal treaty with Panama, 218; Open Door, 293. Hay-Herran draft treaty, 216.

Hay-Pauncefote Treaty, 215.

Hayes, Rutherford B., Isthmian Canal policy, 170, 171.

Hegemony. See Leadership.

Henderson, J. B., A merican Diplomatic Questions, 411.

Hepburn Act, 216.

Hidalgo y Costilla, Miguel, revolt, 27.

Hise, Elijah, draft treaty, 124.

Holy Alliance, cause, 42, 43; manifesto, 43, 44; purpose, congresses, $44-46,48,51$; interventions in Europe, 46, 47; destruction, 47; proposed intervention in America, 48, 49, 55; Canning's proposals to prevent intervention, 52-54; France refuses to intervene, 54 ; Cabinet debate on stand against political system, 60, 61; Cabinet discussion of form of protest against intervention by, 62-64; Monroe's message on, $67,68,84$.

Honduras, Squier's draft treaty, 124 ; treaty of 1864,156 ; movement for protectorate, 333 . See also Central America; Latin America; Pan-AmeriCAN.

Huelsemann incident, 121, 122.

Huerta, Victoriano, refusal to recognize, 319, 334.

Hull, W. I., Monroe Doctrine, 417. 
Humboldt, Alexander von, and Isthmian Canal, 117.

Hungary, American sympathy (1849-50), 121-123, 139.

Hurlbut, Stephen A., and ChileanPeruvian War, 178, 179.

IMPERIALISM, national sentiment, $362,373$.

Ingraham, Duncan N., Koszta affair, 123.

International law, relation of Monroe Doctrine, 80, 81, 199-201, $316,351,352,354,367$; and inferior nations, 320 ; and European War, 397.

International Year Book, 409.

Intervention of Europe in America, proposed by Holy Alliance, 48, 55; suggested American-British coöperation against (1818), 48; Adams and Russian threat, 51 ; Canning's policy of joint action against, rejection of it, 52-54, 58-60; French disclaimer of intention, 54 ; elements of protest of United States, 56 ; Madison on, 58 ; recognition of American states and right to prevent, 60 ; discussion of form of American protest, 62-64; Monroe Doctrine on, 67, 71, 79; Clay's resolution (1824), 89; Clay on effect of Monroe Doctrine, 90 ; Falkland Islands case, 105; minor instances, 106, 142, 152; Polk's doctrine, 114; Cass's doctrine, 132, 134 ; Buchanan's policy, 138; fear not realized, 142; Buchanan on collection of debts, 143: Seward's policy, 144; Monroe Doctrine as a deterrent, 145; joint and French expedition against Mexico, 145, 151, 153, 312; extent of right to redress grievances and insults, 147, 233, 379; by consent, opposed, 180 ; exercise of international police power to forestall, 226, 232, 233, 237, 260, 318, 369 ; Venezuelan episode (1902-3), 230, 231, 275277, 317; causes, $315,316$. See also next title; Claims; Protection.
Intervention of United States in Latin America, no attempt to check anarchy (1829-45), 110; instances, 136, 325 ; in ChileanPeruvian War, 178-180; to protect Americans, 191, 192 ; in Cuban Insurrection, 207210 ; as last resort only, 225 ; in non-American affairs; 227 . See also Leadership; Police; Protection; Protectorates.

Isolation of Europe as foundation for Monroe Doctrine, 2, 3. See also Two SpHeres.

Isthmian Canal, Panama Congress instructions, 96; New Granada Treaty (1846), 117119,219 ; first interest, 117 ; early complications, 118 ; and British claim in Central America, 118, 119; Hise's and Squier's draft treaties, 124; Clayton-Bulwer Treaty, 124, 125 ; controversy over it, 125 ; treaty and Monroe Doctrine, 125-127, 140; land transit (1853), 129; Walker's filibustering, 137; naval demonstration (1856), 138; Seward's interest and treaties contrary to Clayton-Bulwer Treaty and joint control, 156-158, 341 ; lack of public interest, 156, 163, 171, 181 ; Fish's policy opposing joint control, 168 ; American surveys, 168; French Company and work, 169, 185; Evarts and Hayes on paramount interest and American control, 169-172; Blaine on American control and sole guaranty of neutrality, 172-174; influence of British control of Suez Canal, 174, 175, 222; draft Zavala Treaty (1884), 176; Cleveland opposes sole control, 185 ; charter for Nicaragua Company, 186 ; Harrison opposes European domination, 186; controversy over routes, Hepburn Act, 186, 216, 222,341 ; rising public interest (1893), 193; and VenezuelaGuiana boundary incident, 205; and Cuba, 208; Clayton-Bulwer Treaty abrogated, sole 
Isthmian Canal - continued

American control, 214, 215, 221 ; question of neutralization, 215, 217, 344; draft treaty with Colombia, rejected by her, 216 , 217 ; Panama Revolution, recognition, 217, 219, 220, 321, 324,346 ; Panama Treaty for construction, 218; purchase of French rights, 218; construction as mandate from civilization, 219; watch over approaches, 225, 237; share of Isthmian states in policy, 243; Hayes' "coast line" theory and protectorates, 260, 333, 369,384 ; attempts to placate Colombia, $324,333,346$; demand for control by United States, 341, 342 ; French Company and foreign control, 342 ; application of Constantinople Convention, 342 ; equal commercial use, 343 ; toll preferential, 343 ; fortification, 343 ; effect on coasting trade, 344 ; on Atlantic trade with Asia, 345 ; on Japanese relations, 345 ; on Latin-American trade, 345 ; on Central-American relations, 346 ; on relations with Latin America in general, 346 ; with Mexico, 347; necessity of American Doctrine for defense, $373,397$.

Italians in South America, 247. Italy, coercion on Venezuela (1902), 231, 276, 317.

Itata incident, 191.

Iturbide, Augustin de, rule in Mexico, 31 ; overthrown, 38.

Jackson, Andrew, and Texas, 108; in Florida, 325; and Falklands, 325.

Japan, Asiatic Monroe Doctrine, 79, 297, 298; Magdalena Bay episode, $235,296,311$; opening, 283; extraterritoriality, 289 ; character of American influence, 290; understanding with United States on China (1908), 294, 295; Knox's note on Manchurian railways, 295, 296 ; test of American Doctrine, 296, 297; extraterri-
Japan - continued toriality in China, 297; and Isthmian Canal, 345.

Jecker bonds, 146.

Jefferson, Thomas, on Doctrine of Isolation, 12, 13; on cession of Louisiana to France, 15, 25 ; Lewis and Clark Expedition, 16; attitude toward West Indies (1791), 25; and Miranda, 25 ; and Cuba, 27, 29 ; on transfer of territory, 28; advice on Monroe Doctrine, 58.

Johnson, Andrew, as annexationist, 158.

Johnson, Reverdy, on Taylor and Isthmian transit, 126.

Joint intervention. See. INTERvention; Pan-Americanism ; Two Spheres.

Jones, Thomas A. C., seizure of Monterey, 108.

Iuarez, Benito P., recognition and draft treaty, 137; confiscation of church property, 143; and European claim, 146; and Confederate States, 148.

Kasson, J. A., Evolution of the Constitution, 417.

Keasbey, L. M., Nicaragua Canal, 417.

Kiao Chao, seizure by Germany, 274.

Kilpatrick, Hugh J., and ChileanPeruvian War, 179.

Knox, Philander C., as Secretary of State, 234, 377; Magdalena Bay episode, 235 ; note on joint administration of Manchurian railways, 295, 296; and Nicaragua, 331 ; and Colombia, 333, 346.

Kossuth, Louis, in United States, $122,123$.

Koszta affair, 123.

Kraus, Herbert, on Monroe Doctrine, 354; Monroedoktrin, 407, 417.

Krudener, Madame, and Holy Alliance, 44.

La Abra case, 261.

Latané, J. H., United States and Spanish America, 412. 
Latin America, origin, 4; contrast with English colonies, 5, 6; and . American Revolution, $7,8,24$; first inroads of United States, 14-16; condition as colonies, 20-22; race elements then, 22,23 ; influence of French Revolution, 24; Miranda's schemes and expedition, 24-26 ; first revolutions (1806-12), 26, 27; second era of revolutions (1814-21), 30,31 ; sympathy of United States, 32; neutrality and filibustering, 32, 33; recognition of belligerency, 33 ; recognition by United States, 33, 34 ; social and material conditions (1823), 35, 36 ; political conditions (1823), 36, 37 ; possibility of union then, 37,38 ; instability of governments, 38 , 39 ; Spain's determination to reconquer, 40 ; French designs, 41 ; British attitude, 42 ; attitude of United States (1823), 55; confidence in, declines, 98,105 ; lines of development $(1827-44), 101,102$; Spain recognizes, 102; Congress (1847) and plan of union, 102; anarchy, 103; recognition of de facto governments by United States, 104, 245, 319 ; commercial treaties, 104; conditions in $1861,142,143$; Seward on shortcomings, 144 ; lack of interest in $(1869-82), 162,181,182$; change in attitude of United States diplomatists (1869-85), 181 ; question of public opinion, 244,245 ; present population and physical force, $245-247$; present racial and social conditions, $247,248,273$; character of present government, 248-250; chances of union, 250; three groups, 251 ; A B C combination, 251,252 ; liking of Monroe Doctrine, 252-254; dislike of it, 254,255 ; territorial conditions (1823, 1915), 303305 ; relative population (1823, 1915), 304; political changes and European relations (18231915), 315, 316; opinion of
Latin America - continued

United States government, 375. See also Claims; Pan-AmerICANISM ; ReCOGNITION ; MonROE Doctrine and cross references under it, and states by name.

Law, question of inter-American, 377-379 See also INTERNATIONAL LAW.

Lawrence, T. J., Disputed Questions, 412.

Leadership of United States, Canning's statement and opposition, 54,97 ; purpose and results of Monroe Doctrine, $82,83,350$; Calhoun's theory, 110; Taylor on mediation, 130; Monroe Doctrine and world-wide moral, 139; Fish on, 165; policy and peace, 176,177 ; public indifference, 181,182 ; Olney's "practically sovereign" doctrine, 196 ; voice in all American questions, 208; superior power and authority, 237 ; opposition of Latin America to mentorship, 254, 376, 377 ; and attitude toward joint action, 255, 256, 382; and Japanese leadership in Asia, 298; responsibility to Europe, 317, 318; to Latin America, 318,319 ; Kraus on, 354; in Doctrine of Permanent Interest, 369. See also Intervention of United States; Protection; Protectorate; Sovereignty.

Leavitt, Joshua, Monroe Doctrine, 418.

Lesseps, Ferdinand de, Panama Canal, 169 ; on Monroe Doctrine, 169.

Lewis and Clark Expedition, 16.

Lexington, U.S.S., at Falklands, 325.

Liberia, recognition, 145; protection of United States, 212,288 , 289.

Lobos Islands incident, 136, 287. Lodge, Henry C., on American Doctrine, 201, 202; Magdalena Bay episode, 235.

Lopez, Narcisso, Cuban filibustering, 121. 
Louisiana, Genêt's projected expedition, 11; Jefferson on cession to France, 15, 25; purchase, 15.

Lowrie, Walter, American State Papers, Foreign, 420.

MacCorkue, W. A., Monroe Doctrine and Haiti, 418.

McKinley, William, and Cuba, 208, 209; calls Pan-American Congress, 227 ; and imperialism, 373.

McKinley Tariff, reciprocity, 187, 188, 339.

Mackintosh, James, on Monroe Doctrine, 84 .

McLane, Robert M., Mexican draft treaty, 138, 148.

McMaster, J. B., United States, 410; With the Fathers, 412.

Madison, James, and Miranda, 25 ; on transfer of territory, 27 ; on special interest in Latin America, 28; policy toward Latin America, 33; advice on Monroe Doctrine, 58 .

Magdalena Bay episode, 235, 296,311 .

Mahan, Alfred T., on flexibility of Monroe Doctrine, 110; and reservation in Hague Convention, 213; America and International Conditions, 412; America and Sea Power, 412; Problem of A sia, 412.

Maine, U.S.S., destruction of, 208.

Malloy, W. M., Treaties, 420 .

Manchurian railways, Knox's note on joint administration, 295, 296.

Mann, Dudley, Hungarian mission, 121.

Marcy, William L., Koszta affair, 123; as Secretary of State, 128; Gadsden Purchase, 135; and Hawaii, 136, 286; and Declaration of Paris, 139; Sound dues treaty, 139.

Marietta, U.S.S., at Ceiba, 331.

Mason, John Y., Ostend Manifesto, 134.

Mathews, L. K., Essays in American History, 412.

Maximilian, as Emperor of Mexico, 146, 153 ; executed, 154.
Mediation, Taylor on, in LatinAmerican troubles, 130. See also LEADERSHIP.

Mena, Luis, as ruler of Nicaragua, 332.

Metternich, Prince, and legitimacy, 43, 76; on Monroe Doctrine, 85.

Mexican War, and Monroe Doctrine, 113; backward step, 386.

Mexico, Hidalgo revolt, 27 ; independence, Iturbide, 31 ; recognized by United States, 34; federal government, 37, 250 ; proposed Cuban expedition, 91 ; hostility towards United States, 104; Buchanan's policy of annexation, 138; conditions (1861), 142; joint European expedition against, 143 , 145, 146 ; Corwin's mission and draft treaty, 144, 148; French plans, 146, 312; Maximilian, 146; refusal of United States to join expedition, 147 ; Seward's policy on French in, 149-151; withdrawal of French, 153, 154; potential power, 252; La Abra case, 261 ; Pious Fund case, 267; under Diaz, 333; present problem, free hand and responsibility of Unitêd States for solution, $334,335,364$; effect of Isthmian Canal on relations, 347 ; possibility of protectorate, 361. See also Latin America; Pan-Americanism.

Mexico City, Pan-American Congress, 227.

Meyer, Edouard, on Monroe Doctrine, 278.

Militarism, Monroe Doctrine as provoking, 355; lessons of European War, 389-391. See also Peace; Preparedness.

Miquelon Island, status, 310 .

Miramon, Miguel, Jecker bonds, 146.

Miranda, Francisco de, schemes, 24; expedition (1806), 25; rule in Venezuela, 27.

Mizner, Lansing B., Barrundia case, 323.

Mole St. Nicholas, lease, 145. 
Monroe, James, and Latin-American agents, 29 ; predicts recognition of Latin-American states, 33 ; policy as to recognition, 33,34 ; and threat of European intervention (1818), 48; and joint action with England, 48, $52,58,59,62$; character as President, 57; and reply to Russian note on political systems, 61 ; and form of protest against intervention, 62 ; and authorship of Monroe Doctrine, 64, 65; message, 66-68.

Monroe Doctrine, uncertainty of meaning, 1, 140; element in rival colonization of America, 4 ; and American Revolution, 7 ; ground work, 55,56 ; boldness, 56; debt to British attitude, 57, 66; character of framers, 57 ; advice of Jefferson and Madison, 58; choice of policies, 59; Cabinet discussion of joint declaration with England, 59, 60; of European political system, 60, 61 ; of scope of protest against intervention, 62-64; Adams and Monroe as authors, 64; Latin-American source, 65; Canning's claim, 66 ; text, 66-68; wide vision, 69; analysis, 70-83; commercial motive, 77, 94, 337; influence of Cuban situation, 78, 79; Japan's equivalent for China, 79, 297, 298; and peace, 81,82 ; and international law, 80, 81, 199-201, $316,351,352,354,367$; effect of pronouncement in Europe, 8486; in Latin America, 86; in United States, 87; efforts for legislative form, 89, 115, 132 ; Clay's interpretation, 89-91; Adams's statement (1826), 91 ; original a composite, 98 ; status in $1826,98,99$; period of quiescence (1827-44), 101; and protection. of slavery, 109; and change of conditions, 110, 199,236 ; causes of reawakening (1844), 110 ; Polk's interpretation, 113-115, 120, 352; and treaty with New Granada (1846), 119; and Clayton-
Monroe Doctrine - continued

Bulwer Treaty, 125-127, 140 ; Cass's interpretation, 132, 134; status in 1861, 140, 141; Seward's ignoring, 148-150, 152 ; and formation of Dominion of Canada, 154, 155, 158; sufficiency as basis of policy (1845-69), 161; Grant's interpretation, 163-165; De Lesseps on French Canal and, 169; Granville on, 174; Frelinghuysen on force and application, 176; Olney's exposition, 194-198; Cleveland's view, 198, 199; Salisbury's rejoinder, 199-201 ; force, 195, 199; Lodge on, 201, 202; status in 1898,205 ; reservation in Hague Conventions, not a subject for arbitration, 213, 350 ; inapplicable to situation (1898-1903), 221, 222 ; problems (1901-15), 223, 224; Latin-American scepticism of altruism, 244; liking and dislike of Latin America, 252255 ; not applied to Pacific Islands, 283; cult, 300 ; as defense of sovereignty, 351 ; European recognition, 352 ; recent foreign definitions, 352-354; no basis for fears which caused, 354 ; reason for untested acceptance, 371,372 ; facts of origin, 401. See also AMERICAN Doctrine; ANNEXATIONS; Colonization ; Geographical eXtent ; Intervention ; Isthmian Canal; Latin America ; Leadership ; Pan-AmerICANISM ; Paramodnt INTERest ; Peace; Permanent Interest ; Political system ; Protection; Self-defense; Transfer of territory; Two SPheres.

Monterey, seizure (1842), 108.

Montevideo, English occupation, 26.

Moore, J. B., (ed.) Digest, 407, 420; American Diplomacy, 412; International Arbitrations, 412.

Morocco, Germany and, 275, 281. Morrison, H. A., Books on International Canal, 407. 
Moses, Bernard, Spanish Dependencies in South America, 413.

Mosquito Coast, British claim, 118, 119, 125, 127, 141, 214, 312.

Naples, intervention of Holy Alliance, 46, 47.

Napoleon I, and cession of Louisiana, 15 ; and Spain, 26 ; LatinAmerican schemes, 26.

Napoleon III, American opinion, 117 ; and Mexican expedition, 146.

Naturalization, Koszta affair, 123.

Naval and coaling stations, and guano islands, 137; Mole St. Nicholas, 145; effort to obtain Solana Bay, 151; desire for Tigre Island, 156 ; Pearl Harbor, 185; establishment by non-American powers, 235; in Bonin Islands, 287; Magdalena Bay episode, 235, 296, 311.

Navarino, battle of, 47 .

Navy, and Pan-American defensive alliance, 394. See also Preparedness.

Neutral trade, services of United States to rights, 14.

Neutrality, Washington's policy, 10 ; necessity, 14 ; during LatinAmerican revolutions, 32, 33; Monroe Doctrine on, 68; and protection of Latin America, 95, 96; American, in European

War, 281. See also next title.

Neutrality of Isthmian Canal, joint guaranty in ClaytonBulwer Treaty, 124; Blaine on sole American guaranty, 172, 173 ; provisions in Hay-Pauncefote Treaty, 215, 217 ; actuality, 342-344.

New Granada. See Colombia.

New International Encyclopadia, 409.

Nicaragua, appeal for protection (1847), 119; Hise's draft treaty, 124; Mosquito Coast controversy, 125, 127, 141, 214, 312; Dickinson-Ayon Treaty, 157 ; draft Canal treaty (1884), 176,185 ; practical protectorate, 234, 331-333; Bryan's draft treaty, 332. See also Central America; Isthmian Canal;
Nicaragua - continued Latin America; Pan-AmeriCANISM.

Nootka Sound Convention, 24.

Olney, Richard, on Monroe Doctrine and international law, 80; as Secretary of State, 184; on Venezuela-Guiana boundary controversy and American Doctrine, 194-198; occasion for interference in boundary dispute, 202-205; and intervention in Cuba, 208; as exponent of American Docirine, 302 ; Canal poliey, 341; results of "fiat" policy, 377.

Open Door, Hay's note, acceptance, 293; understanding with Japan (1908), 294, 295; Knox's note on Manchurian railways, 295, 296.

Oregon country, rival claims, 17, 18; Russian ukase of 1821,17 ; Nootka Sound Convention, 24; Adams' opposition to Russian ukase, 49, 50; Monroe Doctrine on, 66, 67; Russian treaty (1824), 88; settlement of British controversy, 113.

Orinoco Steamship Company case, 267.

Ostend Manifesto, 134, 135.

Pacific Ocean, Seward on dominance, 133.

Page, Walter H., on exploitation of Latin America, 240, 241.

Pan-American Union, origin, 190.

Pan-Americanism, Wilkinson's suggestion (1808), 28; Panama Congress, 93-98, 243; Fish on joint policy, 166; proposed congress (1881), 177, 178; proposed joint intervention in Chilean-Peruvian War, 180; Washington Congress (1890), 189-191; Mexico Congress (1901), 227, 228; Rio de Janeiro Congress (1906), 228, 229,264 ; Root on all-American public opinion, 229; Buenos Ayres Congress (1910), 229, 253 ; Scientific Congresses, 229; general results of Congresses, 230 ; Taft on common interests, 
Pan-Americanism - continued 234; question of joint action and leadership of United States, $237,243,255,256$; Wilson on spiritual interest, 240; and race prejudice, 255 ; coöperation in Doctrine of Permanent Interest, 369 ; organization and maintenance of American Doctrine, 379-381; problems of defensive alliance, 393, 394.

Pan-Iberianism, 256.

Panama, Republic of, revolution and recognition, 217, 219, 220, 223, 321, 324; Canal treaty, 218 ; protectorate, 328 ; Colombia and recognition, 333, 346.

Panama Canal. See Isthmian.

Panama Congress, call, purpose, joint protection, 93-95; opposition to participation and protection, 95; instructions to American commissioners, 96; British commissioner, 96, 97; failure, 97, 243.

Panama Railroad, 129.

Paraguay, independence, 38; punitive expedition, 136,325 . See also Latin America; PanAmericanism.

Paramount Interest, Doctrine of, in Monroe Doctrine, 82, 83, 161, 162, 299; Everett's anticipation, 131 ; Evart's application to Isthmian Canal, 170 ; Blaine on, 179; and Olney Doctrine, 205 ; in recognition of Panama, $217,218,220,222$; application (1898-1903), 221, 222; Webster on, in Hawaii, 283; and China, 292; in Caribbean Sea, 351. See also Monroe DocTRINE and cross references under it.

Patouillet, Joseph, Imperialisme Américain, 418.

Paul of Russia, grant to RussianAmerican Company, 17.

Paxson, F. L., South American Republics, 418.

Pazos, Vicente, on Creoles, 23 ; work on Spanish America, 35; rhetoric, 36 .

Peace, and Monroe and American Doctrines, 81, 82, 110, 226, 307, $309,351,355,360-362,385$,
Peace - continued

386 ; adverse influence of LatinAmerican conditions, 316, 391393 ; promotion, 385 ; world's belief in doctrine of force, 389 $391,397,402$; and protectorates, 392.

Pearl Harbor, naval station, 185.

Pedro I of Brazil, 31.

Pelletier case, 262.

Pereyra, Carlos, Doctrina de Monroe, 418.

Perez Triano, Santiago, on Monroe Doctrine, 254; Doctrina Drago, 418.

Permanent Interest, Doctrine of, statement, 368-370; determination to maintain, 373 ; force of example, 374-376; and mentorship, 376, 377 ; no pacts without promise of defense, 377 ; question of inter-American law, 377-379; Pan-Americanism and maintenance, 379381 ; maintenance by joint action of self-chosen powers, 381,382 ; and arbitration, 383, 384 ; success of American diplomacy and overconfidence, $387-389$; and world's belief in doctrine of force, 389-391, 402; Latin-American conditions and need of force, 391-393; problems of Pan-American defensive alliance, 393, 394; unilateral defense alone reliable; 395,396 ; necessity of doctrine, 396-398, 402; willingness to defend it, 398, 399, 402 ; necessity of preparedness, 399-401, 403. See also Monrox DocTRINE, and cross references under it.

Perry, Matthew C., Japanese expedition, 283; and Bonin Islands, 287.

Peru, independence, 30 ; Spanish War, 152; Chilean War, intervention of United States, 178180. See also Latin America ; Pan-Americanism.

Pétin, Hector, on Monroe Doctrine, 352; Doctrine de Monroe, 418.

Phelps, E. J., America and Europe, 418. 
Philippine Islands, annexation, 210 ; status, 211 ; and Doctrine of Paramount Interest, 221 ; Germany and, 274; problem of possession and independence, 290-292.

Pierce, Franklin, as President, 128; and Cuba, 134; and Walker's filibustering, 137 ; and Monroe Doctrine, 141.

Pious Fund case, 267.

Pitt, William, and Miranda, 24.

Platt amendment, 327.

Plumer, William, on authorship of Monroe Doctrine, 65.

Poinsett, Joel, agent to Buenos Ayres, 29; Clay's instructions on Monroe Doctrine (1825), 90.

Police power, Roosevelt on international, 226, 318; Root on no duty, 237; Wilson on orderly governments, 239; resulting peace, 360 ; exercise in Mexico, 364 ; success, 364 ; and collection of foreign claims, 365 . See also Protectorates.

Polignac, Prince de, and intervention in Latin America, 54.

Political Science Quarterly, 409.

Political system of Europe, first use of phrase, 13; designs on America (1823), 56; Russian note and American reply, 51, 60, 61; Monroe Doctrine on, $67,68,74,81,350,351,354$, 401 ; Clay's instructions on, 90 ; Polk's doctrine, 114; American influence in Europe (1830-51), 116,117 ; Seward on protection against, 152, 319; and Dominion of Canada, 155; and annexation of Alaska, 156; Johnson on, 158; Blaine on, 173; Olney on, 196 ; Cleveland on, 198; Roosevelt on, 226 ; Root on preservation from, 229 ; and retention of Philippines, 291 ; changes, 312 ; American feeling of responsibility, 313 .

Polk, James K., as annexationist, $108,112,113,115,120$; interpretation of Monroe Doctrine, 113-115, 302, 350; and Cuba, 120,121 ; results of policy, 127 ; Diary, 420.
Population of Latin America, 246 ; relative in America $(1823,1915)$, 304.

Porto Rico, annexation, 210; Wilson on responsibility to, 241 . See also West Indies.

Portugal, and Holy Alliance, 47.

Portuguese in South America, 247.

Pownall, Thomas, on Doctrine of Isolation, 9.

Preparedness, Roosevelt on, 226, 227; freedom from military burden, 226, 229; American Doctrine as militarism, 355; and peace in Latin America, 391-393; and Pan-American defensive alliance, 393, 394; influence of success of American diplomacy, 387-389; necessary for defense of American Doctrine, 399-401, 403.

Press, opposition of Holy Alliance to liberty, 46.

Prevost, J. B., agent to Spanish America, 34.

Protection of Latin America by United States, effect of Monroe Doctrine, 73, 79; Latin-American acceptance, 87, 119, 253; policy of Adams and Clay, 89, $92,94,96,99$; joint protection in call of Panama Congress, 93 ; opposition in Congress, (1826), 95, 96; permanent need not expected, 102 ; Bayard on, 184 ; Olney and Cleveland on duty, 196, 197, 199; Salisbury's denial of right, 200 ; Tyler on, of Hawaii, 284; as essence of American Doctrine, $299,350,351$; actuality, 325, 326; in Doctrine of Permanent Interest, 369 ; disinclination to promise, 377. See also ProTECTORATES ; SELF-DEFENSE.

Protectorates, Buchanan's policy in Mexico, 138; establishment in Santo Domingo, 231-233, $260,329,330$; policy of Taft and Wilson, 233, 236; not a duty, 237 ; virtual, in Hawaii, 284; Samoa, 288; Liberia, 288, 289 ; as outside American Doctrine, 305; all Latin America as, 326 ; Cuba, 327, 328; Panama, 328; Nicaragua, 331- 
Protectorates - continued

333 ; proposed, in Honduras, 333 ; question in Mexico, 333335,347 ; fixed policy and probable results, 335 , 336 ; influence of Isthmian Canal, 346 ; influence on general relation with Latin America, 347; as drain on home energy and welfare, 357; peace in, pressure needed to preserve it, 360,392 , 395 ; reaction on United States, 361 ; and responsibility to Europe, 361; and commerce, $362-364$; as solution of foreign claims problem, 365 ; in Doctrine of Permanent Interest, 369 ; public opinion on, 373 ; as acts of sympathy, 386 . See also Protection; SoverEIGNTY.

Prussia. See Holy Alliance.

Public debts. See Claims.

Public opinion, Root on allAmerican, 229; in Latin America, 244, 245.

QUallah Battoo, bombardment, 289.

Race elements in Latin America (1823), 22, 23; present conditions there, 247 ; prejudice and Monroe Doctrine, 255; and Pan-Americanism, 382.

Railway, projected Pan-American, 228, 229, 393.

Randolph, John, on Clay's intervention resolution, 89 .

Reciprocity, with Latin America, 187-189, 339; Hawaiian, 287; experience of Canadian, 347.

Recognition of Latin-American nations, preliminaries, 28, 29; Monroe predicts (1815), 33; Monroe's policy, 33; and Florida question, 34; begun, 34 ; European opposition, 51; proposed joint action with England, 52 ; Canning's policy and proposal to Rush, 52-54; and right to prevent intervention, 60 ; by Great Britain, 85, 86 ; of de facto governments, 104, 245, 319 ; Seward's policy, 144, 145; of Republic of Panama,
Recognition - continued

217 ; Roosevelt's defense, 219 , $220,223$.

Reddaway, William F., on authorship of Monroe Doctrine, 64; on progressiveness of Doctrine, 300; Monroe Doctrine, 419.

Reinsch, P. S., World Politics, 413.

Reiter, George C., Barrundia case, 323.

Representation, opposition of Holy Alliance, 46.

Republican government, character of Latin-American, 248250,375 ; defense as element of future American Doctrine, 366,368 ; Latin-American opinion of United States, 375.

Revolution, responsibility for damage to aliens, $259,268$.

Rhodes, J. F., United States, 410.

Ribet, Joseph, Vol de l'Aigle, 419.

Richardson, J. D., Messages of the Presidents, 421.

Ringwalt, R. C., Briefs on Public Questions, 408.

Rio de Janeiro, Pan-American Congress, 228, 229, 264.

Rodney, Cæsar, agent to Spanish America, 33.

Roman Catholic Church in Latin America, 247.

Romero, Matias, Mexico and United States, 413.

Roosevelt, Theodore, and Canal route, 216; and Hay-Herran Treaty, 217; recognition of Republic of Panama, defense of action, 217, 219,220, 223, 321 ; interpretation of American Doctrine, 224-227, 233, 302 ; and Pan-American Congress, 228; Santo Domingo protectorate, $231-233,329$; on intervention for contract claims, 265 ; and Venezuelan episode, 277,318 ; understanding with Japan, 294; disclaims territorial ambition, 308 ; on American Doctrine and peace, 309 ; on flexibility of Doctrine, 309; on international police power, 318; on inferior states and American Doctrine, 322; on Cuban protectorate, 328 ; intervention in Central America, 
Roosevelt - continued

330 ; policy of protectorates, 335 ; and expansion, 353; American Ideals, 413; Autobiography, 421.

Root, Elihu, as diplomatist, 224 ; speech at Pan-American Congress, 228,229 ; interpretation of American Doctrine, 235238,242 ; and Drago Doctrine, 266 ; understanding with Japan, 294 ; and Colombia, 333.

Rush, Richard, and Oregon, 1, 50; Canning's proposals on Latin America, 52-54, 59, 62; Memoranda, 421.

Russia, Oregon controversy, 4951 ; note and reply on political system, 60,61 ; treaties limiting American claims, 88; and Hawaii, 286; Knox's note on Manchurian railways, 295, 296; as future great power, 314 . See also Holy Alliance; EURopean War.

Russian America. See Alaska.

St. Bartholomew Island, transfer to France, 311.

St. John Island, attempted annexation, 151.

St. Louis, U.S.S., Koszta affair, 123.

St. Pierre Island, status, 310.

St. Thomas Island, attempted annexation, 151.

Salisbury, Marquis of, on Venezuela-Guiana boundary and Monroe Doctrine, 199-201.

Salvador, desires annexation (1822), 37. See also Central America ; Latin America ; Pan-Americanism.

Samoa, joint control and division, 185, 288.

San Martin, José de, conquests, 30 ; and Bolivar, 30.

Santa Anna, Antonio Lopez de, and Gadsden Purchase, 135.

Santo Domingo, early interest of United States, 29 ; conditions (1861), 142; recognition, 145 ; Spanish attempt to reconquer, 151 ; attempted annexation by United States, 151 ; control of customs, pro-
Santo Domingo - continued

tectorate, 231-233, 260. See also West INDIES.

Schouler, James, United States, 410. Schuyler, Eugene, American Diplomacy, 413.

Scientific Congresses, Pan-American, 229.

Scott, Alexander, agent to Buenos Ayres, 29.

Scruggs, W. L., Columbian and Venezuelan Republics, 413.

Self-defense, as element of Monroe and American Doctrines, $75,76,127,202,237,299,317$, 349 , 351, 357; Webster on, 92; and Ostend Manifesto, 135; Seward's policy, 153; Cleveland on, 198; in recognition of Panama, 219 ; LatinAmericans on, 253, 255; efficiency of Doctrine for, 355, 358 ; as element of future Doctrine, 366, 369, 396, 397, 401.

Seward, William H., and Hungary, 122 ; foreign policy as Senator, 129; on dominance of the Pacific, 132, 133; attitude as Secretary toward Latin America, 143-145, 153 ; as annexationist, 145, 151; on joint expedition against Mexico, 147; ignores Monroe Doctrine, 148-150, 152; and French in Mexico, 149-151, 153,154 ; and Spanish in Santo Domingo, 151; and Spanish-Chilean War, 152; on protection of republican system, 152, 319; on Dominion of Canada, 154; Alaska, 155; and Canal, 156, 341; results of diplomacy, 159, 302 .

Sherrill, Charles M., on joint American responsibility, 381 .

Shipping, in Latin-American trade, 340.

Shuster, W. Morgan, in Persia, 313.

Siam, American influence, 290.

Slavery, protest against Cuban emancipation (1829), 107; Monroe Doctrine and protection, 109 ; and diplomacy (1853-61), 129; and Ostend Manifesto, 135. 
Solana Bay, desired for naval station, 151.

Solar, Alberte del, Doctrina de Monroe, 419.

Soulé, Pierre, Ostend Manifesto, 134.

Sound dues, American treaty, 139.

Sovereignty, Root on equal rights of all states, 229; LatinAmerican states at Hague Congress, 229; American Doctrine and preservation, 236, 237; and Doctrine of the Big Stick, 318 ; doctrine of inferior nations, 319,320 ; doctrine applied to Latin America, 321 ; practice of asylum, 322-324; Monroe Doctrine as defense, 351 ; and status of foreigners, 378. See also Protectorates. Spain, colonizing rivalry in America, 4; colonial empire and American Revolution, 7, 8; American treaty of 1795,14 ; cession of Louisiana, 14, 15; loss of Florida, 15, 34; Nootka Sound Convention, 24; and French Revolution, 24; Napoleon's control, 26 ; reactionary rule of Ferdinand, 30; and revolted colonies, 40 ; relations with England, 41; intervention of Holy Alliance, 46, 47; reception of Monroe Doctrine, 84 ; recognizes LatinAmerican states, 102 ; joint expedition against Mexico, 146 ; attempt to reconquer Santo Domingo, 151; Chilean War, 152.

Spaniards in South America, 247. Spanish - America. See Latin America.

Spanish-American War, 208-210 ; attitude of Germany, 277; as parting of the ways, 373 .

Squier, Ephraim G., draft treaty, 124.

Statesman's Year Book, 409.

Stevenson, Andrew, and Cuba, 107.

Strobel, Edward H., in Siam, 290. Subsidy, postal, to encourage trade, 189, 340; and tariff, 340.
Suez Canal, influence on Isthmian Canal policy, 174, 175, 222; question of neutralization, 342 . Sumner, Charles, on annexation of Alaska, 156; and peace, 386.

Taft, William H., policy toward Latin America, 233-235; and Nicaragua, 332 ; policy of protectorates, 335 ; and arbitration, 383; United States and Peace, 413 .

Tariff, proposed Customs Congress, 228; and shipping, 340; proposed Pan-American customs union, 347 ; and protectorates, 362-364. See also RECIPROCITY.

Taylor, Zachary, and Hungary, 121 ; and Isthmian Canal, 126; on mediation in Latin America, 130.

Tehuantepec transit, 341.

Teller Resolution, 209.

Territory. See Annexations; Geographical extent ; TransFER.

Texas, desire of United States for, 108; Calhoun's protest on British abolition propaganda, 109; annexation, 112.

Tigre Island, controversy, 119, 312 ; Seward's desire for, 156 .

Tillinghast, W. H., Handbook, 409.

Tirpitz, Admiral von, colonial policy, 274.

Tolls on Isthmian Canal, 343.

Torres, Manuel, and formation of Monroe Doctrine, 65.

Torres Caicedo, J. M., Union Latino, 414.

Toussaint L'Ouverture, rule, 29. Trade. See Commerce.

Transfer of territory between American states, adverse policy of United States in Chilean-Peruvian War, 179, 180; Pan-American Congress opposes conquests, 190; from republic to monarchy opposed, 324 ; in Doctrine of Permanent Interest, 369. See also next title and Annexations.

Transfer of territory in America by European states, after 
Transfer - continued

American Revolution, 14; Jefferson on Louisiana, 15; Madison's opposition, 27,28 ; and original Monroe Doctrine, 74, 79,310 ; protests as to Cuba (1825-44), 91, 106-108; Grant on, $152,163,164$; various phases of question, 310 ; origin of opposing doctrine, 310 ; and West Indies, 310 ; single instance, 311 ; and transfer of home country, 311. See also preceding title, and CoLonization.

Treitschke, Heinrich G. von, doctrine of force, 390 .

Trescot, William H., Chilean mission, 180.

Tucker, George F., on Monroe Doctrine, 351 ; Monroe Doctrine, 419.

Turner, F. J., Guide, 406.

Tuyll, Baron von, Oregon negotiations, 49 ; and intervention in Latin America, 51; and political system question, 60,61 .

Two Spheres, Doctrine of, early announcement, 8-10; Washington's policy, 10, 11 ; in Farewell Address, 11, 12; Jefferson and John Adams on, 12, 13; common sense, 13, 14; counter doctrine of European aloofness, 14,16 ; J. Q. Adams on, 16; in formulation of Monroe Doctrine, 62-64; Monroe Doctrine on, $68,70,80$; effect on, of economic changes, 70, 314 ; Clay's doctrine, 90, 91; Polk's doctrine, 114 ; and sympathy with Hungary, 121-123, 139 ; England as American power, 126, $140,175,197,201$; and joint guaranty of Cuba, 130, 131; United States in European diplomacy (1854-61), 139; and joint intervention in Cuba, 167, 181 ; and proposed intervention in Chilean-Peruvian War, 179 ; Harrison on, 186; obsolete, 211, 212, 305, 314 ; Cleveland on Congo Conference, 212; Roosevelt on non-American intervention and sympathy, 227; and Jews in Russia, 235; and
Two Spheres - continued protectorate of Liberia, 289; and Asiatic policy, 294, 295; and American feeling of general responsibility, 313 ; and Monroe Doctrine of Europe, 356; no place in future American Doctrine, 367. See also INtervention; World Power.

Tyler, John, on protection of Hawaii, 284.

Unilateral control of AMeriCan Doctrine, 237, 243, 354. Union, possibilities of LatinAmerican, 37-39, 250. See also A B C; Pan-Americanism.

United States, General Index to Foreign Relations, 408; Reports of Committee on Foreign Relations, 421; Foreign Relations, 421.

Uruguay, and debt to Brazil, 324. See also Latin America; PanAmericanism.

Usher, Roland G., on commercial motive of Monroe Doctrine, 77; on extra-American defense of Latin America, 359 ; on PanAmericanism, 380; Pan-Americanism, 419.

Van Buren, Martin, and Cuba, 106, 107.

Vanderbilt, Cornelius, and Walker's filibustering, 137.

Venezuela, Miranda's revolt, 27 ; formation of modern state, 102 ; unjust claims arbitration (1875), 177; European intervention (1902-3), 230, 231，275-277, 317 ; federal government, 250 ; law on rights of aliens, 259 ; Orinoco Steamship Company case, 267. See also next title; and Latin America; PanAmericanism.

Venezuela-Guiana boundary controversy, Frelinghuysen on application of Monroe Doctrine, 176 ; origin, 193; Cleveland's message, 194, 198, 199 ; Olney's despatch, 194-198; Salisbury's reply, 199-201; real occasion for interference by United States,202-205 ; settlement, 205. 
Verona; Congress of (1822), secret treaty, 45, 46, 49.

Virginius affair, 167.

WAgNer, Adolph, on Monroe Doctrine, 275.

Walker, William, filibustering, 137.

War. See Militarism; Peace; Preparedness.

Washington, George, on Doctrine of Isolation, 9, 10; allied policy, 10, 11; Farewell Address on isolation, 11, 12 ; and Miranda, 24.

Water Witch incident, 136.

Webster, Daniel, on Monroe Doctrine and existing colonies, 72 ; on reception of Monroe Doctrine, 87; on self-preservation in Monroe Doctrine, 92; on protection of Latin America, 95; and Cuba, 108; Huelsemann incident, 122 ; on paramount interest in Hawaii, 283 ; and annexation of Hawaii, 285, 286.

Wellington, Duke of, leaves Congress of Verona, 45.

West Florida, treaty of 1795,14 ; annexation by United States, $15,27,34$.

West Indies, transfers after American Revolution, 14; early trade of United States, 22; Jefferson's denial of desire for (1791), 25 ; French designs (1823), 41 ; and extent of Monroe Doctrine, 77; commerce of, as motive of Monroe Doctrine, 78, 337 ; territorial conditions (1823, 1915), 303,305 ; as outside of field of American Doctrine, 305, 306 ; power of United States, 308; and doctrine of no transfer of territory, 310; Big Stick and
West Indies - continued peace, 360. See also islands by name.

Westengard, Jens I., in Siam, 290.

Wharton, Francis, (ed.) Digest, 421.

White, Henry, at Congress at Algeciras, 281.

Wilkinson, James, on combination of American states, 28.

William II of Germany, colonial policy, 274 ; on United States, 277.

Wilson, Woodrow, Latin-American policy, 238-241; on responsibility to Porto Rico and Hawaii, 291; on independence for Philippines, 292 ; as exponent of American Doctrine, 302 ; and Mexico, 334, 335; policy of protectorates, 335; and arbitration, $383 ;$ American People, 410.

Winsor, Justin, on American diplomacy, 387.

Woolsey, T. S., America's Foreign Policy, 414.

World power, United States as, inevitably, 87; advent, 210 colonies, and Asian policy, 211 ; policy in Africa, 212; penalty, 281 ; spirit of consolidation, future great powers, 314 ; spirit of American people, 315. See also LeADERSHIP ; Two SPHERES.

Wu Ting Fang on Monroe Doctrine, 292.

Wyse, Lucien B., Canal concession, 169.

Yucatan, Polk on annexation, 115.

Zavala DRAFT TREATY (1884), $176,185$. 



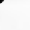






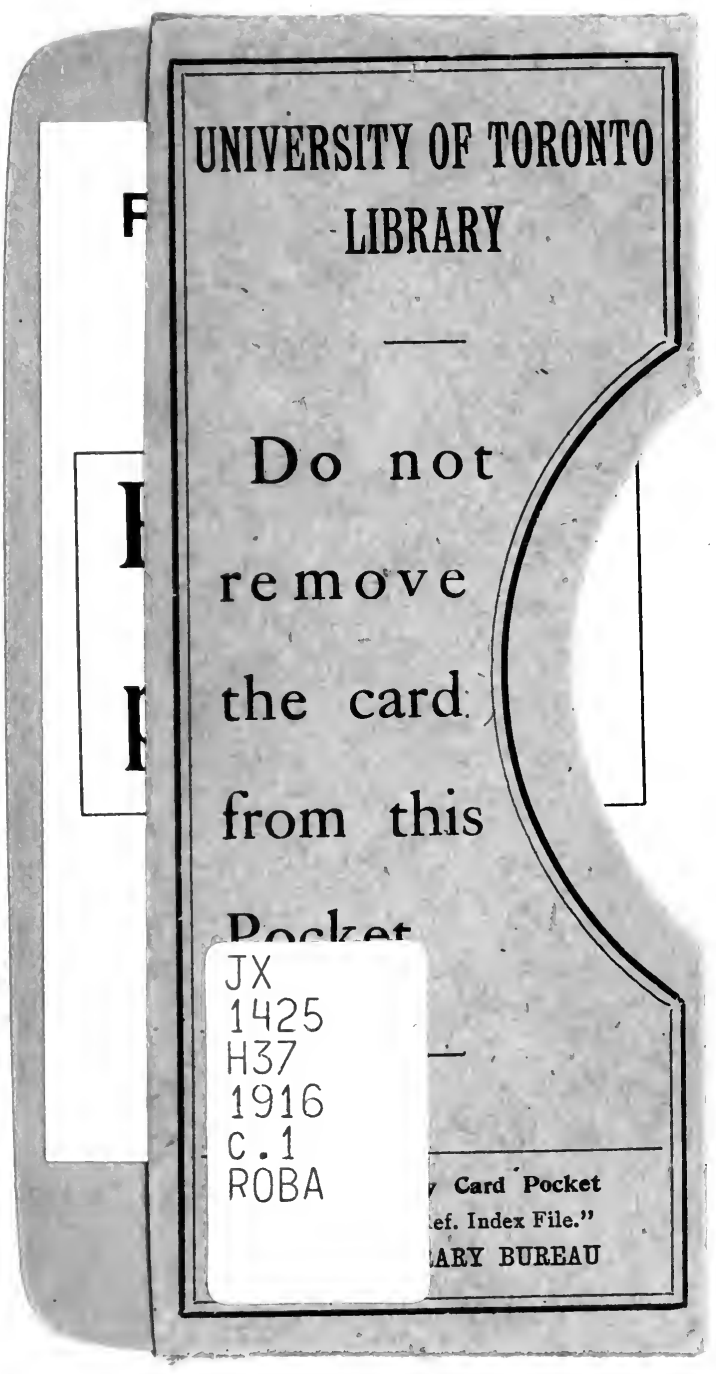


